\title{
Ivony Éva
}

A szubjektív életminőség alakulása

a gazdasági válság időszakában Magyarországon 


\title{
Társadalomtudományi és Nemzetközi Kapcsolatok Kar \\ Szociológia és Társadalompolitika Intézet
}

\author{
Témavezetők: \\ Dr. Keller Tamás PhD \\ Dr. Spéder Zsolt PhD
}

(C) Ivony Éva, 2018 
Budapesti Corvinus Egyetem Szociológia Doktori Iskola

A szubjektív életminőség alakulása a gazdasági válság időszakában Magyarországon

doktori értekezés

Ivony Éva

Budapest, 2018 



\section{Tartalomjegyzék}

1.Bevezetés.................................................................................................................... 11

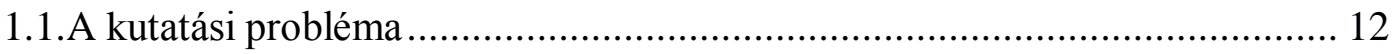

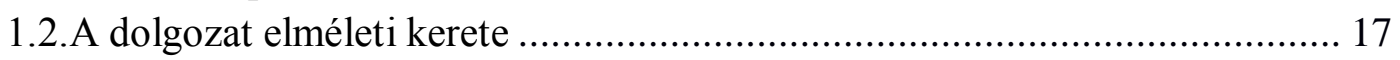

1.3.A kutatás módszertana, főbb megállapításai, eredményei ............................. 20

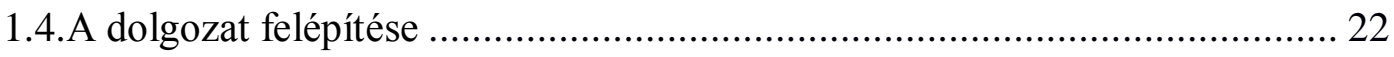

2.Elméletek és kutatási elózmények ....................................................................... 23

2.1.Az életminőség mérése - társadalmi jelzőszámok, indikátorok ...................... 23

2.2.A szubjektív jóllét elméleti megközelítései és kutatási előzményei ................ 32

2.3.A szubjektív jóllét alakulása konjunktúrák és gazdasági válságok idején....... 49

2.4.A szubjektív jóllét mérésének megbízhatósági és érvényességi kérdései ....... 58

3.A kutatás hipotézisei ............................................................................................ 62

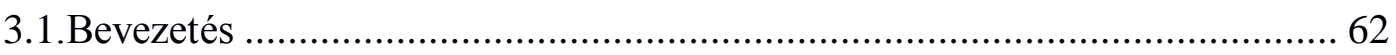

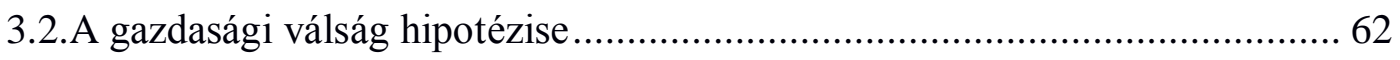

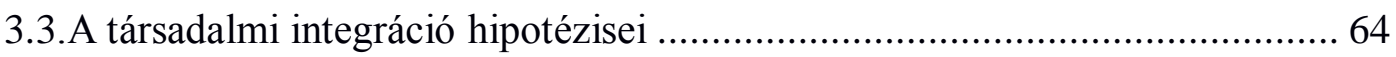

3.4.A szubjektív egészség, biztonságérzet és jövedelmi körülmények alapján

kialakított társadalmi nagycsoportok polarizációjának hipotézisei......................... 67

3.5.Az egyéni anómia- és elidegenedésérzet hipotézise....................................... 69

3.6.A személyes jellemvonás hipotézise …………………………………........ 70

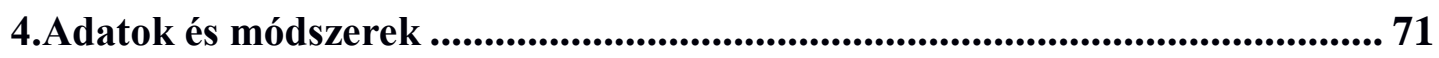

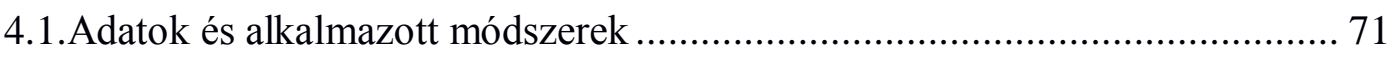

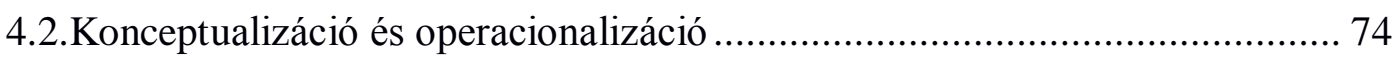

4.2.1.A szubjektív életminőség operacionalizálása és mérése ........................... 75

4.2.2. A magyarázó változók operacionalizálása ………………………......... 83

4.2.3.A kontrollváltozók specifikálása ……………………........................ 90

5.Eredmények ......................................................................................................... 92

5.1.A Szubjektív Életminőség Index elemeinek jellemzői ................................... 92

5.2.A szubjektív életminőség összetevőinek meghatározó tényezői...................... 99

5.3.A szubjektív életminőség alakulása az eltérő társadalmi-demográfiai cso-

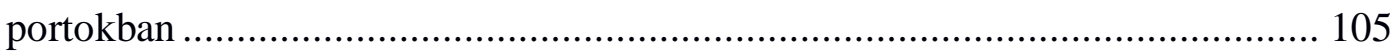

5.4.A gazdasági válság hipotézisének vizsgálata ............................................ 115

5.5.A társadalmi integráció hipotéziseinek vizsgálata ……………………….... 118

5.6.A szubjektív egészség, biztonságérzet és jövedelmi körülmények alapján kialakított társadalmi nagycsoportok polarizációs hipotéziseinek vizsgálata...... 120

5.7.Az anómia és elidegenedésérzet hipotézisének vizsgálata .......................... 122

5.8.A személyes beállítottság hipotézisének vizsgálata ..................................... 123

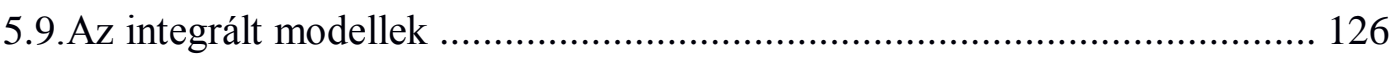

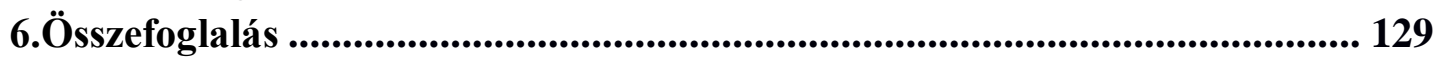

6.1.A kutatási kérdések és hipotézisek megválaszolása ..................................... 129

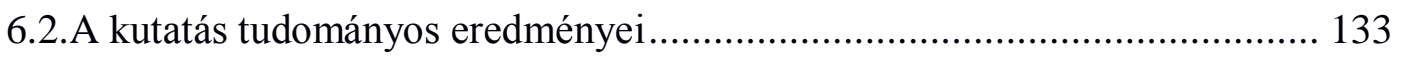

6.3.A kutatás korlátai és javasolt további kutatási irányok ................................ 136 


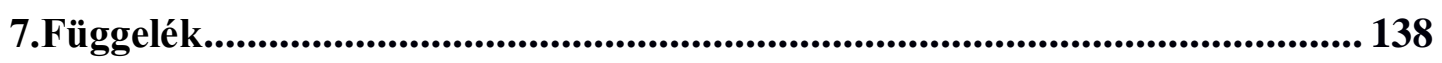

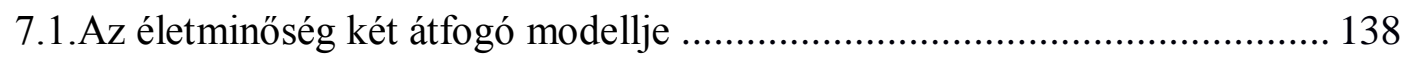

7.2.A többdimenziós élettel való elégedettségi index .................................... 139

7.3.A szubjektív életminőség multidimenzionális modellje és jellemzői............ 140

7.4.A szubjektív egészség, jövedelmi helyzet és biztonságérzet változói ............ 142

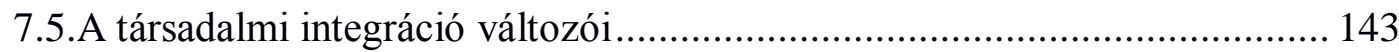

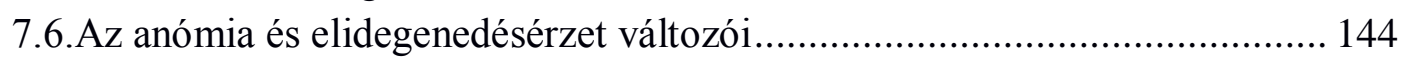

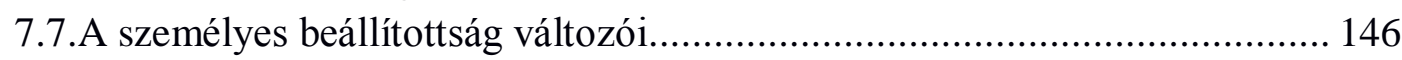

7.8.A kontrollváltozók leíró statisztikái....................................................... 149

7.9.A szubjektív életminőség dimenzióinak jellemzői .................................... 151

7.10.A szubjektív életminőség társadalmi-demográfiai jellemzői ..................... 161

7.11.A kontroll- és magyarázó változók megoszlása az összevont mintában ..... 167

7.12.A dichotóm változók leíró statisztikái az összevont mintában................... 168

7.13.A társadalmi integráció és a szubjektív indikátorok hipotéziseinek a szubjektív életminőség mértékével kapcsolatban felépített regressziós modelljei ..... 169 7.14.A hipotéziscsoportoknak a szubjektív életminőség mértékével kapcsolatos regressziós modelljei ...................................................................... 171

7.15.A szubjektív életminőség integrált regressziós modellje (II.) ................... 173

8.Irodalom .................................................................................................. 174

9.Publikációs jegyzék ............................................................................................. 187

Melléklet: 1 db DVD statisztikai mellékletekkel és a tézis dokumentációival........ 


\section{Táblázatjegyzék ${ }^{1}$}

1.táblázat Makrogazdasági és jövedelemegyenlőtlenségi mutatók alakulása a gazdasági válság előtt és azt követően Magyarországon, 2003 -

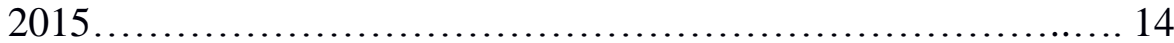

2.táblázat A szubjektív jóllét egyszerü modellje.............................. 34

3.táblázat A szubjektív jóllét összetett modellje.............................. 34

4.táblázat A rövid távú pozitív-negatív érzéseket mérő változók megoszlásai

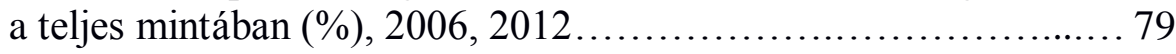

5.táblázat A rövid tartamú pozitív-negatív érzések egyenlegét mérő skála, 2006, 2012 [átlag (szórás)]................................... 79

6.táblázat A Szubjektív Életminőség Index statisztikái, 2006, 2012 (fökomponens-elemzés)............................................ 80

7.táblázat A Szubjektív Életminőség Index és a dieneri szubjektív életminőséget mérő mutatók,illetve Chekola indikátorának kapcsolata, 2006, 2012 (korrelációs együtthatók)...

8.táblázat

Az anómia és elidegenedés skála és elemeinek statisztikái, 2006

9.táblázat

Az anómia és elidegenedés skála és elemeinek statisztikái,

2012

10.táblázat A szubjektív életminőség öt fö összetevőjének (having, loving, being, boldogság, érzelmi balansz) regressziós modelljei, 2006, OLS (sztenderdizálatlan Beta koefficiensek, szignifikancia szintek)............................................ 100

11.táblázat A szubjektív életminőség öt fö összetevőjének (having, loving, being, boldogság, érzelmi balansz) regressziós modelljei, 2012, OLS (sztenderdizálatlan Beta koefficiensek, szignifikancia szintek) ............................................. 101

12.táblázat A szubjektív életminőség öt fö összetevőjének (having, loving, being, boldogság, érzelmi balansz) integrált regressziós modelljei, 2012, OLS (sztenderdizálatlan Beta koefficiensek, szignifikancia szintek)

13.táblázat A szubjektív életminőség öt fö összetevőjének (having, loving, being, boldogság, érzelmi balansz) integrált regressziós modelljei, 2012, OLS (sztenderdizálatlan Beta koefficiensek, szignifikancia szintek) 104

14.táblázat A gazdasági válság hipotézisének regressziós modelljei a szubjektív életminőség mértékével kapcsolatban, összevont keresztmetszeti adatok, OLS (sztenderdizálatlan regressziós együtthatók, szignifikancia szintek).

1 A Táblázatjegyzék nem tartalmazza a Függelék táblázatait. 
15.táblázat A társadalmi integráció, a szubjektív jövedelmi helyzet, a szubjektív egészség és a biztonságérzet hipotéziseinek a szubjektív életminőség mértékével kapcsolatos regressziós modelljei, összevont keresztmetszeti adatok, OLS (sztenderdizálatlan regressziós együtthatók, szignifikancia szintek)..... 121

16.táblázat Anómia és elidegenedés skála átlagainak összehasonlítása (kétmintás t-próba), összevont keresztmetszeti adatokat............... 123

17.táblázat A hipotéziscsoportoknak a szubjektív életminőség mértékével kapcsolatos regressziós modelljei, összevont keresztmetszeti adatok, OLS (sztenderdizálatlan regressziós együtthatók, szig-

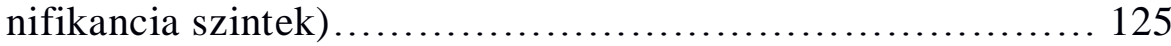

18.táblázat Integrált regressziós modellek a szubjektív életminőség mértékével kapcsolatban, összevont keresztmetszeti adatok, OLS, (sztenderdizálatlan regressziós együtthatók, szignifikancia szintek) 


\section{Ábrajegyzék ${ }^{2}$}

1.ábra A szubjektív jóllét affektív oldalát mérő index átlagértékének változása az európai országokban 2006-2015 között (ESS, 2006, 2012, 2015).......... 13

2.ábra Az élet globális értékelése: az élettel való elégedettség és a boldogság alakulása Magyarországon, 2001-2015 (átlag) (ESS, WDH)........... 15

3.ábra A multidimenzionális szubjektív életminőség alakulása Magyarországon a gazdasági válság előtt és azt követően - hioptetikus modell................. 16

4.ábra A házas és nem házas nők és férfiak szubjektív jólléte, 1972-1989...... 65

5.ábra A Szubjektív Életminőség Index megoszlásai..................................... 80

6.ábra A szummatív Szubjektív Életminőség Skála megoszlásai............... 83

7.ábra Az anómia és elidegenedésérzetet mérő skála megoszlásai.................. 86

8a.ábra A Szubjektív Életminőség Index és az életkori korcsoportok kapcsolata,

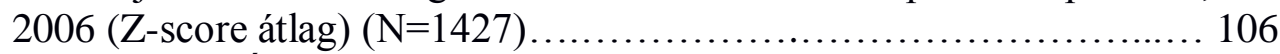

8b.ábra A Szubjektív Életminőség Index és az életkori korcsoportok kapcsolata,

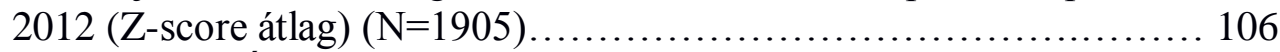

9a.ábra A Szubjektív Életminőség Index és az iskolai végzettség összefüggése,

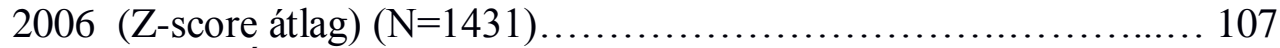

9b.ábra A Szubjektív Életminőség Index és az iskolai végzettség összefüggése,

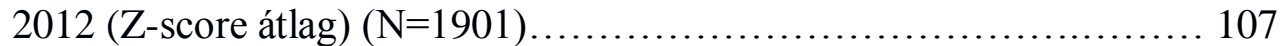

10a.ábra A Szubjektív Életminőség Index és a családi állapot kapcsolata, 2006 (Z-

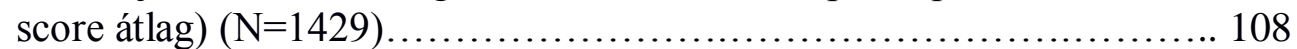

10b.ábraA Szubjektív Életminőség Index és a családi állapot kapcsolata, 2012 (Z-

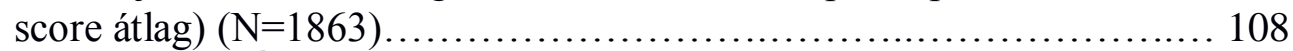

11a.ábra A Szubjektív Életminőség Index és a foglalkozás összefüggése, 2006 (Z-

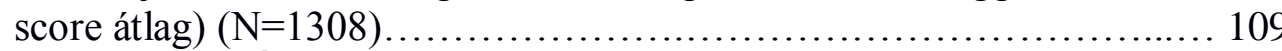

11b.ábra A Szubjektív Életminőség Index és a foglalkozás összefüggése, 2012 (Z-

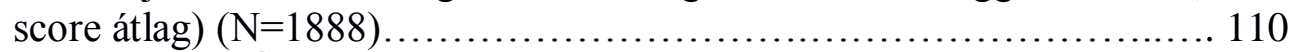

12a.ábra A Szubjektív Életminőség Index és a szubjektív egészségi állapot kapcso-

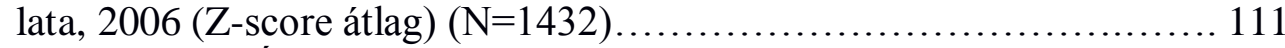

12b.ábra A Szubjektív Életminőség Index és a szubjektív egészségi állapot kapcso-

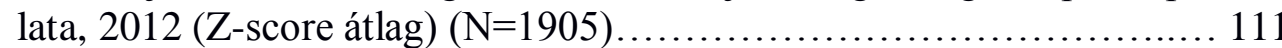

13a.ábra A Szubjektív Életminőség Index és a lakókörnyékhez kapcsolódó biztonságérzet összefüggése, 2006 (Z-score átlag) $(\mathrm{N}=1419) \ldots \ldots \ldots \ldots \ldots \ldots 112$

13b.ábra A Szubjektív Életminőség Index és a lakókörnyékhez kapcsolódó biztonságérzet összefüggése, 2012 (Z-score átlag) $(\mathrm{N}=1871) \ldots \ldots \ldots \ldots \ldots \ldots \ldots \ldots \ldots \ldots$

14a.ábra A szubjektív életminőség alakulása a jövedelmi helyzet szubjektív értékelése függvényében, 2006 ( $\mathrm{Z}$-score átlag) $(\mathrm{N}=1424) \ldots \ldots \ldots \ldots \ldots \ldots \ldots 113$

14b.ábra A szubjektív életminőség alakulása a jövedelmi helyzet szubjektív értékelése függvényében, 2012 (Z-score átlag) $(\mathrm{N}=1887) \ldots \ldots \ldots \ldots \ldots \ldots \ldots \ldots \ldots$

15a.ábra A Szubjektív Életminőség Index és a személyes beállítottság kapcsolata,

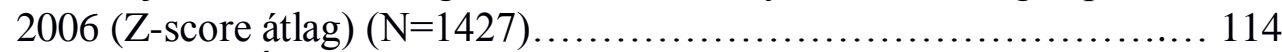

15b.ábra A Szubjektív Életminőség Index és a személyes beállítottság kapcsolata,

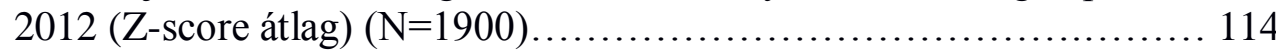

2 Az ábrajegyzék nem tartalmazza a Függelék ábráit. 


\section{Köszönetnyilvánítás}

Ezúton szeretnék köszönetet mondani professzoraimnak, tanáraimnak, pályatársaimnak. Köszönettel tartozom a Doktori Iskola tanárainak, mindenekelőtt Lengyel Györgynek, Kolosi Tamásnak, Szántó Zoltánnak és Moksony Ferencnek, a doktori program keretében átadott tudásuk, szemléletmódjuk, kritikáik és biztatásuk nélkül jelen dolgozat nem készülhetett volna el.

Köszönettel tartozom témavezetőimnek, Spéder Zsoltnak és Keller Tamásnak a kutatás elkészítéséhez nyújtott értékes javaslataikért, észrevételeikért és szakmai támogatásukért.

Köszönöm a TÁRKI Zrt. vezetőinek, vezető kutatóinak, és közvetlen kutatásvezetőmnek, Sik Endrének szakmai tapasztalataik átadását, mellyel pályakezdő szociológusként és Ph.D. hallgatóként támogattak.

Köszönöm a dolgozathoz füzött építő kritikákat Szabó Laurának, Bartus Tamásnak, és Hajdú Gábornak.

Köszönöm a Doktori Iskolának, hogy a doktori tanulmányaimat ösztöndíjjal támogatta, továbbá köszönet illeti a TÁRKI Zrt. Ösztöndíj Bizottságát és a Doktori Iskolát a külföldi tanulmányútjaim támogatásáért.

Köszönöm szeretett családom és barátaim támogatását. 


\section{Bevezetés}

A 2008-as gazdasági és pénzügyi válság szubjektív jóllétre gyakorolt befolyását eltérő elméleti keretbe ágyazva számos szociológiai kutatás vizsgálta. Jelen dolgozatban arra a kérdésre keressük a választ, hogy a magyar lakosság szubjektív életminősége hogyan alakult a recesszió időszakában, illetve az eltérő társadalmi-demográfiai jellemzők mentén kialakított csoportok életminőségbeli különbségei mutattak-e valamilyen irányú és mértékű szignifikáns eltérést a krízist követően a válság előtti időszakhoz viszonyítva. Vizsgálatunkkal a szubjektív jóllét és életminőség kutatási területén elsősorban Erik Allardt $(1973,1976)$ korai jóléti koncepciójához kapcsolódtunk, azonban segédelméletként Ed Diener (1984) affektív jóllét teóriájára is támaszkodtunk.

A dolgozatban a skandináv hagyományokat megtartva, egy multidimenzionális, az egyén szubjektív életminőségét mérő indikátort fejlesztettünk ki. A kompozit mérőeszközt a having-loving-being szükséglet-dimenziók szubjektív mutatóinak (Allardt, 1993), illetve a korai allardti koncepcióban az egyes szükségletdimenziókon elszórtan elhelyezkedő tartós és rövidtávú jóllét-érzéseknek az együtteséből konstruáltuk. A hazai szociológia területén legjobb tudomásunk szerint eddig nem került kifejlesztésre az allardti koncepcióba ágyazott többdimenziós szubjektív életminőség indikátor, így a munkánk újszerüségét részben ez adja, részben pedig a gazdasági válság egyéni jóllétre gyakorolt hatásának ezen új többdimenziós mérőeszköz mentén történő vizsgálata. A kutatáshoz az adatokat az Európai Társadalmi Felmérésnek a 3. és 6. hullámainak felvételei biztosítják, melyek segítségével a szubjektív életminőség alakulását a recesszió időszakában összevont keresztmetszeti adatokon vizsgáljuk meg, többváltozós elemzési technikák alkalmazásával. 


\subsection{A kutatási probléma}

A 2008-as globális pénzügyi és gazdasági válság Európában is jelentős gazdasági megtorpanást eredményezett. Amíg a nyugati demokráciák jellemzően piac-konform, addig a keleti-európai tagállamok elsősorban központi szabályozások útján igyekeztek gazdasági egyensúlyukat visszaállítani, mellyel együtt az eltérő fejlettségü országok hosszabb-rövidebb idő alatt lábaltak ki a recesszióból (Bjørnskov, 2014). A krízis a jólét mértékét is visszavetette, majd minden uniós országban csökkent a foglalkoztatottsági, emelkedett a szegénységi ráta a 20-64 éves népesség körében, ugyanakkor a válság kirobbanását követő első évben csökkent a társadalmi intézményekbe és az emberekbe vetett bizalom átlagos mértéke is (Füstös, 2011, Gábos et al., 2014). Azonban, amíg az intézményi és társadalmi bizalom a lakosság gyors alkalmazkodásának köszönhetően a következő évre megközelítette a krízis előtti átlagos szintet, az európaiak szubjektív életminőségének és jóllétének alakulását ettől a trendtől eltérő, lassabb javulás jellemezte (Ivony, 2017). Az európai lakosság a recesszió kedvezőtlen hatását elsősorban a növekvő munkanélküliség mellett a romló életkörülményeken és a növekvő bizonytalanságérzeten keresztül tapasztalta meg, mely a sérülékeny társadalmi csoportoknál jelentkezett hangsúlyosan (European Commission, 2014). A háztartások kevesebb jövedelemből gazdálkodhattak, kiadásaikat racionalizálták, és sok esetben a családok életmódjukon is változtatni kényszerültek. Kevesebbet fordítottak magukra, szabadidejük aktív eltöltésére, és általában nem terveztek hosszabb távon a jövőre. Általános megtakarítási formaként jelentkezett az egészségügyi kiadások csökkentése, személyes vagyontárgyak értékesítése, ami a fenti változásokkal együtt több stresszt és nyugtalanságot hozott az egyének mindennapjaiba. Mind az országuk gazdaságának rossz állapotáért, mind személyes életükben bekövetkezett kedvezőtlen változásokért a megkérdezettek egyértelmüen a válságot okolták. A krízis előtti időszakban a családok anyagilag és érzelmileg is stabilabb életet élhettek, mint a válság éveiben. A mindennapi stressz, frusztráció és aggodalom az európai lakosság szubjektív jóllétének, elsősorban a jóllét érzelmi aspektusának kedvezőtlenebb alakulásához vezetett a kilábalás időszakában (Greve, 2012). A tagállamok többségében 2006-hoz viszonyítva 2012-ben alacsonyabb átlagos affektív jóllétszint volt jellemző, mely kedvezőtlen tendencia 2015-ben is általános 
európai trendként jelentkezett (1. ábra).

1. ábra: A szubjektív jóllét affektív oldalát mérő index átlagértékének változása az európai országokban ${ }^{3}$ 2006-2015 között (ESS, 2006, 2012, 2015)

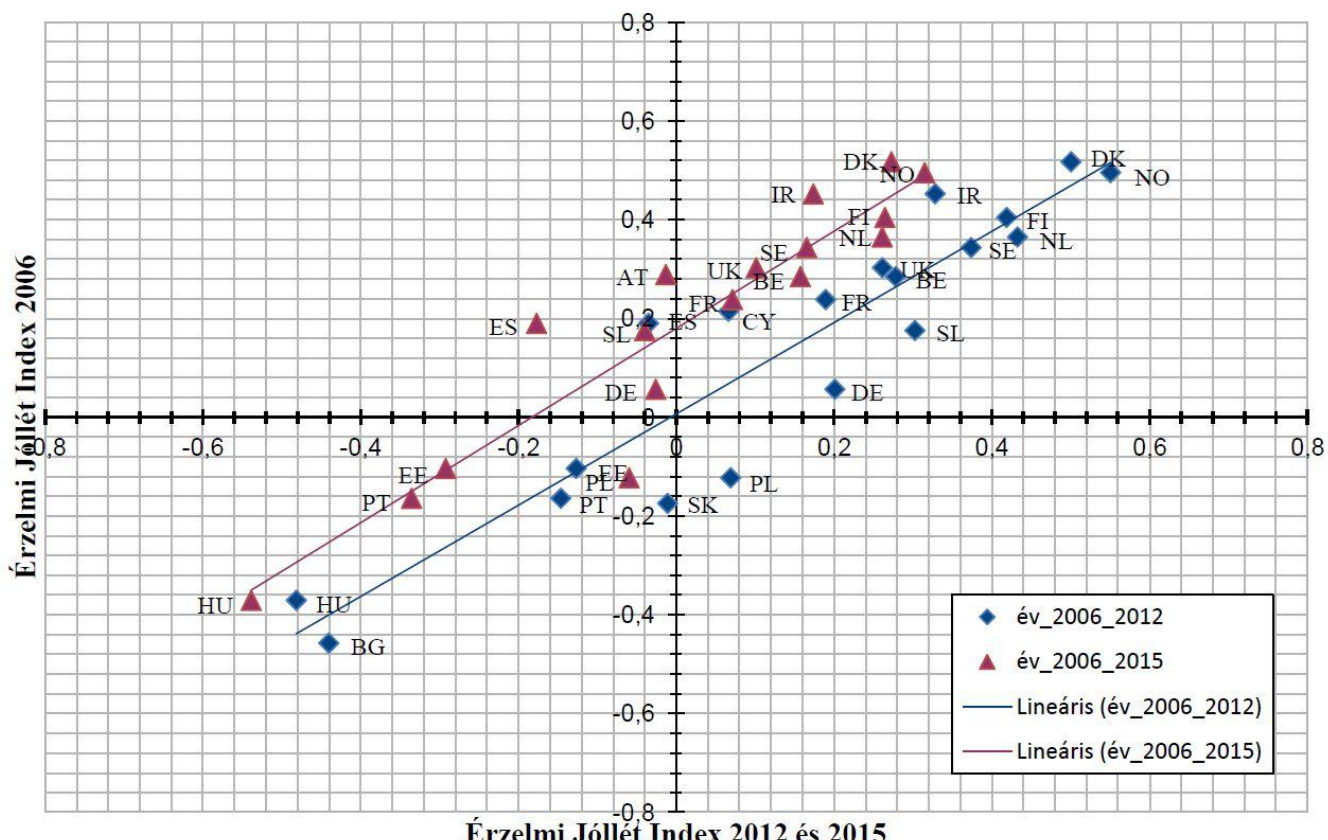

* Forrás: Ivony, 2017. Az ábra az általános boldogságérzet és a rövid távú pozitív-negatív érzések balanszát mérő mutatókkal kialakított érzelmi jóllétet méri minden országban azonos módon, azon országok körében, amelyek minden esetben 2006-ban és legalább 2012-ben, vagy 2015-ben részt vettek az Európai társadalmi felmérésben.

A recesszió Magyarországon is jelentős változásokat eredményezett a gazdasági- és társadalmi folyamatokban, amelyet makrogazdasági és jövedelem-egyenlőtlenségi indikátorok egyértelmủen jeleztek (1. táblázat). Hazánkban a válság kirobbanását követően a bruttó hazai termék volumenindexe a 2008-as értékhez képest 2012-re jelentősen lecsökkent, jóllehet a 2009-es úgynevezett válságévet a stagnálás évei követték, azonban az adatok alapján 2013-tól a gazdaság erősödését figyelhettük meg. A munkanélküliség és foglalkoztatás alakulása ezzel a trenddel hasonló folyamatot mutatott, összességében 2008 és 2012 között a felnőtt népesség körében 3,2 százalékponttal nőtt a munkanélküliségi ráta, azonban elsősorban a fiatalok szorultak ki a munkaerő-piacról, körükben 8,7 százalékponttal emelkedett az

$3 \mathrm{Az}$ országok kódolása: $\mathrm{AT}=$ Ausztria, $\mathrm{BE}=$ Belgium, $\mathrm{BG}=$ Bulgária, $\mathrm{CY}=$ Ciprus, $\mathrm{DE}=\mathrm{Németország}$, $\mathrm{DK}=$ Dánia,$\quad \mathrm{EE}=$ Észtország, $\quad \mathrm{ES}=$ Spanyolország, $\quad \mathrm{FI}=$ Finnország, $\quad \mathrm{FR}=$ Franciaország, $\mathrm{HU}=$ Magyarország, IE=Írország, $\mathrm{NL}=$ Hollandia, $\mathrm{NO}=$ Norvégia, $\mathrm{PT}=$ Portugália, SI=Szlovénia, $\mathrm{SE}=$ Svédország, $\mathrm{SK}=$ Szlovákia, $\mathrm{UK}=$ Anglia. 
állástalanok aránya.

1. táblázat: Makrogazdasági és jövedelem-egyenlőtlenségi mutatók alakulása a gazdasági válság előtt és azt követően Magyarországon, 2003-2015*

\begin{tabular}{|c|c|c|c|c|c|c|c|}
\hline & $\begin{array}{c}\text { GDP } \\
\text { volumen- } \\
\text { indexe } \\
(2000= \\
100,0)\end{array}$ & $\begin{array}{l}\text { Foglalkoz- } \\
\text { tatottak } \\
\text { száma (ezer } \\
\text { fó) }\end{array}$ & $\begin{array}{l}\text { Munkanél- } \\
\text { küliségi } \\
\text { ráta (15-74 } \\
\text { éves } \\
\text { népesség) }\end{array}$ & $\begin{array}{c}\text { Munka- } \\
\text { nélküliségi } \\
\text { ráta } \\
\text { (15-24 } \\
\text { évesek) }\end{array}$ & $\begin{array}{c}\text { Inflációs } \\
\text { ráta** } \\
(\text { előző } \\
\text { év=100,0) }\end{array}$ & $\begin{array}{c}\text { Gini- } \\
\text { index }{ }^{* * *}\end{array}$ & $\begin{array}{c}\mathrm{P} 90 / \\
\mathrm{P} 10^{* * *}\end{array}$ \\
\hline 2003 & 112,6 & $3.921,9$ & 5,9 & 13,4 & 104,7 & 0,316 & 3,90 \\
\hline 2004 & 118,2 & $3.900,4$ & 6,1 & 15,5 & 106,8 & & \\
\hline 2005 & 123,4 & $3.901,5$ & 7,2 & 19,4 & 103,5 & 0,308 & 3,78 \\
\hline 2006 & 128,2 & $3.928,4$ & 7,5 & 19,1 & 104,0 & & \\
\hline 2007 & 128,7 & $3.902,0$ & 7,4 & 18,0 & 107,9 & 0,288 & 3,53 \\
\hline 2008 & 129,9 & $3.848,3$ & 7,8 & 19,5 & 106,0 & & \\
\hline 2009 & 121,4 & $3.747,8$ & 10,0 & 26,4 & 104,0 & 0,292 & 4,11 \\
\hline 2010 & 122,2 & $3.732,4$ & 11,2 & 26,4 & 104,7 & & \\
\hline 2011 & 124,3 & $3.759,0$ & 11,0 & 26,0 & 103,9 & & \\
\hline 2012 & 122,3 & $3.827,2$ & 11,0 & 28,2 & 105,7 & 0,312 & 4,69 \\
\hline 2013 & 124,9 & $3.892,8$ & 10,2 & 26,6 & 101,7 & & \\
\hline 2014 & 130,0 & $4.100,8$ & 7,7 & 20,4 & 100,0 & 0,307 & 4,06 \\
\hline 2015 & 134,1 & $4.210,5$ & 6,8 & 17,3 & 100,1 & & \\
\hline
\end{tabular}

*Forrás: www.ksh.hu; Szivós-Tóth, 2015.

**Az inflációs ráta a harmonizált fogyasztóiár-index adatai szerint.

***Forrás: Szivós-Tóth, 2015. Gini-index az egyenlőtlenség szóródás-alapú mutatója, értéke 0 és 1 között változik, a 0 a teljes egyenlőséget, az 1 a teljes egyenlötlenséget fejezi ki; a P90/P10 a teljes jövedelemeloszlás terjedelmét jellemző mutató, mely a legfelső jövedelmi tized legalacsonyabb jövedelemösszegét (alsó határpontját) viszonyítja a legalsó tized legmagasabb jövedelemösszegéhez (felső határpontjához).

A jövedelemegyenlötlenségek a kilábalás éveiben folyamatosan növekedtek, az anyagi depriváció előfordulásának gyakorisága a teljes népességen belül 2012-ben volt a legmagasabb (Szivós-Tóth, 2013, 2015; Gábos et al., 2016). A lakosság eladósodása már a válság előtt megkezdődött a kedvező lakáshiteleknek köszönhetően, a háztartások egyre kevesebbet spóroltak meg a váratlan kiadásaikra, jövőbeli szükségleteikre. A kilábalás éveiben a kedvezőtlen tendencia folytatódott, 2012-ig a lakosság pénzügyi megtakarításai átlagosan folyamatosan csökkentek, enyhe javulás a 2013-at követő évben volt megfigyelhető (Medgyesi, 2016), de a reálfogyasztás is 2012 után nőtt meg jelentősebben. A magyar társadalom szubjektív jóllétének alakulása e folyamatokhoz hasonló trendet követett (2. ábra). 
2. ábra: Az élet globális értékelése: az élettel való elégedettség és a boldogság alakulása Magyarországon, 2001-2015 (átlag) (ESS*, WDH**)

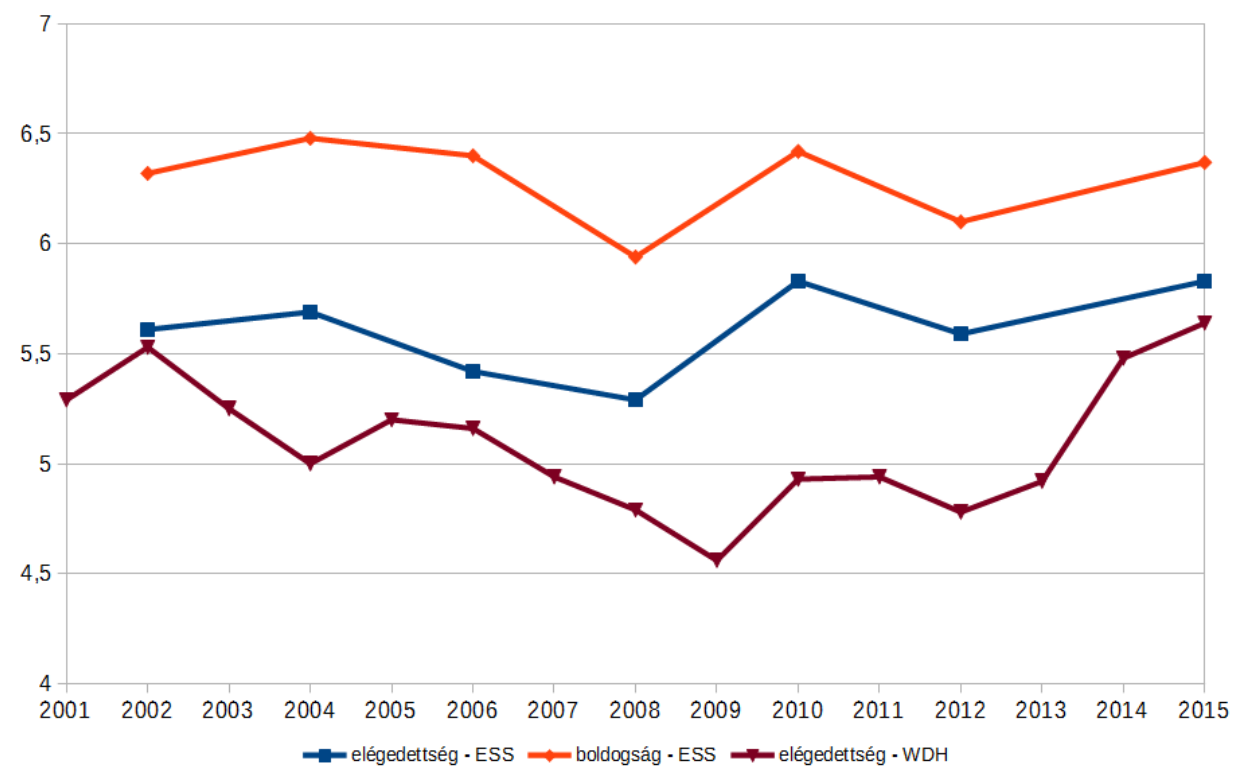

*ESS - European Social Survey adatfelvételének 1 - 7. hullámai (saját számítás). A megkérdezett saját életének racionális és érzelmi értékelését minden hullámban azonos módon kérdezték le: „Mindent összevetve mennyire elégedett mostani életével?” és „Mindent egybevetve, mennyire érzi magát boldognak?”. A válaszokat 0-tól 10-ig terjedő skálán rögzítették, ahol a 0 a teljesen elégedetlen, nagyon boldogtalan, a 10-es a teljesen elégedett, nagyon boldog értékkategóriát jelentette.

**WDH (élettel való elégedettség) - Veenhoven, Ruut (2016), Happiness in Hungary (HU), World Database of Happiness, Erasmus University Rotterdam, The Netherlands. Viewed on 2016-12-17 at http://worlddatabaseofhappiness. eur.nl

Láthatjuk, hogy a lakosság átlagos élettel való elégedettsége és boldogságérzete a válság időszakában jelentősen lecsökkent, és a kilábalás éveiben 2012-re nem érte el a válság előtti szintet. Azonban 2012-től mindkét mutató esetében javulás figyelhető meg. Mind a szubjektív indikátorok, mind a főbb gazdasági- és egyenlőtlenségi mutatók alakulása alapján a 2012-es évet ezért a kilábalás éveinek kumulatív összhatását megragadó időpontként határoztuk meg a kutatásunkban. A fenti társadalmi-gazdasági folyamatok alapján jelen kutatás elsődleges kérdése a következő: hogyan alakult a lakosság többdimenziós indikátorral mért szubjektív életminősége a válságot követően. Jóllehet a bevezetőben elmondottaknak 
megfelelöen a szubjektív életminőség csökkenését valószínüsítjük, azonban a következőkben bemutatásra kerülő szakirodalom alapján ez korántsem egyértelmü. A 3. ábra a kutatás fő hipotézisét mutatja be, mely szerint a szubjektív életminőség a válságból való kilábalás éveiben a korábbi 2006-os értékekhez viszonyítva 2012-re feltételezhetően valamelyest csökkent.

3. ábra: A multidimenzionális szubjektív életminőség alakulása Magyarországon a gazdasági válságot követően - hipotetikus modell

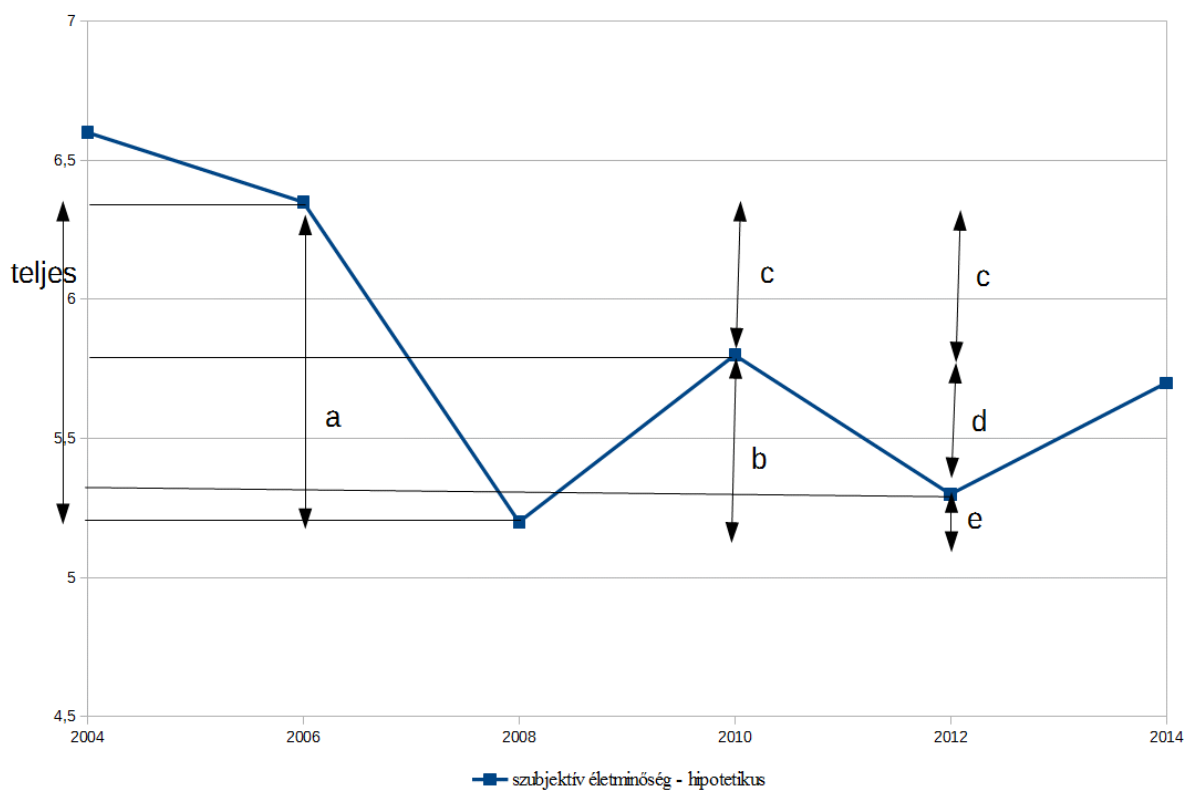

Az ábrán bemutatottak alapján a diagram a szubjektív életminőség hipotetikus alakulását ábrázolja, melyen Y tengelynél 2006 és 2008 között a válság lecsapódásaként bekövetkezett teljes változás (csökkenés) látható. A szubjektív jóllét recessziót követő visszaesése 2010-ben fordulatot vett és javulást mutatott. A 2010es évnél látható javulás mértékét (b), illetve a válság kedvezőtlen hatását (c) betűvel tüntettük fel. Láttuk, hogy a kilábalás elhúzódásának köszönhetően 2010 után ismételt csökkenést mértek az egyitemű indikátorok (2. ábra), melyet itt a 2012-es évnél jeleztünk. Így a 2012-es év hipotetikus értéke összeadódik egyrészt a válság és a kilábalás időszakában bekövetkezett csökkenésekböl: (c) és (d), beleértve azon változásokat is, melyeknek okait nem ismerjük, vagy nem tudjuk mérni, másrészt a 
2010-es év pozitív hatásának átlagértéket javító maradékhatása jelenik még itt meg, amelyet (e)-vel jelöltünk. A szakirodalom szerint a kilábalás túl hosszúra nyúlt, a válságot a döntéshozók rosszul kezelték (Csath, 2010), amit a 2012-es évig folyamatosan romló makro statisztikák is alátámasztottak. Arra a kérdésre azonban, hogy a lakosság többdimenziós indikátorral mért szubjektív életminősége 2012-re a korábbi 2006-os időszakkal összevetve valóban kedvezőtlenebb értéket mutat majd, jelen empirikus kutatás során kísérlünk meg választ adni. Azonban már itt jelezzük, hogy a válság szubjektív életminőségre kifejtett kedvezőtlan hatását, mint periódushatást lehetséges, hogy nem fogjuk tudni mérni.

A társadalmi-gazdasági makrofolyamatoknak az egyéni- és társadalmi élet minőségére kifejtett hatásait számos tudományterület, ma már túlnyomórészt interdiszciplináris kutatások vizsgálják. A társadalomtudósok makroszintü, illetve egyének, társadalmi csoportok helyzetét, körülményeit magyarázó (mikroszintü) megközelítésekre alapozva fogalmazzák meg koncepcióikat. Jelen vizsgálatban figyelmünk elsősorban a társadalmi és egyéni jóllét mikroszintű megközelítéseire irányul, amikor a lakosság átlagos életminőségének, illetve az eltérő társadalmi csoportok életminőségbeli különbségeinek változásait vizsgáljuk, mellyel elsősorban a hazai empirikus szociológiai kutatások területén a szubjektív jóllét vizsgálataihoz kapcsolódunk.

\subsection{A dolgozat elméleti kerete}

Jelen kutatás elméleti kiindulópontja Erik Allardt 'Having-Loving-Being' néven ismertté vált jóléti koncepciója. Allardt jóléti modellje az alapvető emberi szükségletek három fó dimenzióját definiálja: a materiális-, a szociális- és a személyes fejlődés szükségleteit. Az első átfogó dimenzióban ('Having') a materiális szükségletek, az életkörülmények köré csoportosuló fogalmak, a második dimenzióban ('Loving') a személyes érzések, a barátság és a szolidaritás, míg a harmadikban ('Being') a személyes fejlődés szükségleteit megragadó tényezők kapcsolódnak össze (Allardt, 1973). E korai teóriának az egyszerüsített modellje 1993-ban látott napvilágot, melyben a három fó szükségletdimenziót egy-egy objektív és szubjektív indikátor segítségével operacionalizálta a szerző. A szubjektív 
életminőség modelljét ebben az értelemben tehát az objektív mennyiségi indikátorok elégedettségi mutatói képezték le (Allardt, 1993). A dolgozatban a kutatás elméleti megalapozásához a tágabb koncepciót, az általunk kifejlesztett multidimenzionális indikátor operacionalizálásához azonban az utóbbi modellt vettük alapul. A korai allardti koncepció dimenziói tartalmaznak mind tartós érzelmi percepciókat (boldogságérzet), mind átmeneti, időszakos érzések (magány, nyugtalanság) jelenlétét vagy hiányát megragadó indikátorokat. A többdimenziós szubjektív életminőség indikátor kifejlesztése szempontjából ezért lényeges szempontnak tartottuk, hogy az életminőség alakulásában szerepet játszó egyéni érzések allardti meghatározása ('feelings of well-being') a 2. fejezetben részletesen bemutatásra kerülő amerikai koncepcióhoz ('subjective well-being') hasonló elvet követ (Diener, 1994), mely utóbbi teóriát segédelméletként, koncepciónk támogatására hívtuk fel.

Allardt objektív és szubjektív indikátorokat átfogó jóléti koncepciója a nyolcvanas-kilencvenes években hazánkban is hozzájárult a társadalmi folyamatokat monitorozó indikátorrendszer átfogó felülvizsgálatához (Andorka-Kulcsár, 1975a, 1975b; Harcsa-Spéder, 1999). Ugyanakkor az allardti teóriának jelentős hagyománya alakult ki a magyar szociológiában, számos hazai empirikus kutatás elindításához és elméleti megalapozásához járult hozzá (Andorka, 1996; Andorka-Spéder, 1996; Spéder-Paksi-Elekes, 1998; Utasi, 2000; 2006; Spéder-Kapitány, 2002). Azonban kifejezetten az allardti modell alapján kifejlesztett többdimenziós szubjektív életminőség indikátorról a hazai szociológia terén nincs tudomásunk, ezért a kutatás újdonságát egyrészt ez adja, másrészt a lakosság szubjektív életminőségének vizsgálata ezen új multidimenzionális indikátor mentén a gazdasági válságot követő időszakban - ahogyan a bevezetőben ezt már említettük. További újszerüsége a kutatásnak, hogy az objektív indikátorok mellett néhány, a vizsgálat számára kiválasztott szubjektív indikátor mentén kialakított dichotóm társadalmi nagycsoportok életminőségbeli változását vizsgálja, az egymáshoz viszonyított életminőségbeli különbségeik eltéréseinek mérése alapján, a recesszió időszakában és a korábbi, 2006-os évben mért eredmények összevetés útján.

Dolgozatunkban - tekintettel arra, hogy kutatásunk a szubjektív jóllét és életminőség változását általában vizsgálja -, a szakirodalmat a kutatás elméleti keretét meghatározó korai allardti modell megjelenésétől kezdőden tekintjük át. Mindazonáltal a prezentációnk szelektív, azonban egy szélesebb spektrumban 
kívánjuk bemutatni a terület főbb elméleteit és kutatási előzményeit, mint ahogyan az megszokott egy nagyon speciális területre leszükített kutatómunka esetében. Ide értve azt a társadalmi jelzőszám-mozgalmat is, mely bizonyos értelemben bölcsője volt e kutatási terület központi indikátorainak a kifejlődésében. Ugyanakkor, kutatásunk elméleti megalapozását megerősítendő, a koncepciónkhoz alapul vett allardt-i teória 'a priori' alkalmazása mellett további érveket sorakoztatunk fel a dolgozat 2. fejezetében.

Az említett definíciók és fogalmak tisztázására szükséges röviden már itt a bevezetőben kitérnünk. A szakirodalomban egy társadalom jóléte (welfare) elsősorban az objektív indikátorokkal mért gazdasági fejlődés mértékén, az anyagi javakkal való ellátottság javításán alapul. A társadalmak minőségének másik oldalát azonban az életminőségnek, az egyéni jóllétnek (well-being) a fejlődése mutatja meg, melyet elsősorban szubjektív mutatókkal mérnek (Utasi, 2002; Zapf, 2002). Az életminőség (quality of life) szükebb értelemben arra is utal, hogy ,az egyén élete milyen mértékben éri el a kívánatos mértéket szemben a nem kívánatos állapottal, kizárólag a külső tényezőkre helyezve a hangsúlyt, úgy, mint az életkörülmények vagy a jövedelem”. Azonban a tágabb értelemben vett definíció „nem csupán az életkörülmények minőségét, hanem ezen életkörülményekre irányuló egyéni percepciókat, gondolatokat, érzéseket és reakciókat is magában foglalja” (Diener, 2005:4). A szubjektív életminőség ugyanakkor szélesebb körben fog át az élet céljaihoz kötődő percepciókat, míg a jóllét ezzel szemben több életterülethez kapcsolódó tartalmat takar (Sirgy et al., 2006: 413). ${ }^{4}$ Ezeknek a meghatározásoknak megfelelően a kutatásunkban az egyéni életminőségen az életkörülményekkel és az élet céljaival kapcsolatos individuális percepciók együttesét értjük, amelyek így a többdimenziós szubjektív életminőséget definiálják.

Kutatásunk ugyanakkor nem irányul a magyar lakosság pszichológiai jóllétének (Ryff, 1989, Ryff-Keyes, 1995), vagy lelkiállapotának (Kopp, 2008) a vizsgálatára. Továbbá nem citálunk olyan vizsgálatokat, melyekben ugyan multidimentionális jóllét-indikátor került kidolgozásra, de a kutatás elméleti keretét a World Health Organization (WHO) mentális és viselkedési zavarok statisztikai osztályozása biztosította, ahogyan láthattuk Huppert és So (2013) tanulmányában,

4 A kutatásunkban az empirikus eredmények bemutatásakor a szubjektív életminőséggel ekvivalens fogalmakként használjuk a szubjektív jóllét, az egyéni jóllét és a jóllét fogalmait. 
majd az erre épülő Harrison és szerzőtársai (2016) munkájában. Ezen kutatások központi fogalmi eleme a ,flourishing”, mely fogalom a pszichológiai jóllét koncepciójához kapcsolódik, elsősorban Keyes $(2002,2007)$ korai munkáin alapulva, és a mentális jóllétet meghatározva.

\subsection{A kutatás módszertana, főbb megállapításai, eredményei}

Az elemzéshez az adatokat az Európai Társadalmi Felmérésnek (European Social Survey, továbbiakban: ESS) a keresztmetszeti felvételei biztosítják. Az adatfelvétel alapját egy minden országban azonos standard kérdőív képezte, melyhez minden alkalommal más és más témakörök kiegészítő moduljai csatlakoztak, bizonyos időközönként rotálódva. A „Személyes és társadalmi jóllét” („Personal and Social well-being”) témaköre 2006-ban és 2012-ben került lekérdezésre. A modulhoz tematikusan kapcsolódó szubjektív jóllét alapkérdései (élettel való elégedettség, boldogság) nemcsak az említett modul során, de minden évben a kérdőív standard részét képezték. A minta véletlenszerü mintavétel alapján került kiválasztásra. A 3. hullám adatfelvételét a Magyar Gallup Intézetet készítette el 2006. november 21. és 2007. január 28. között ( $\mathrm{N}=1518$ fö), a 6. hullámot a TÁRKI Társadalomkutatási Zrt. vette fel 2012. november 11. és 2013. február 17. között $(\mathrm{N}=2014$ fó). Az adatok az ESS dokumentációjában leírtaknak megfelelően, a mintába kerülés eltérő valószínűségét kiegyenlítő súlyváltozóval kerültek súlyozásra, az összevont adatok a megfelelő keresztmetszeti súlyokkal.

A kutatásban kifejlesztett többdimenziós életminőség indikátort az elméleti koncepció alapján operacionalizált mutatók segítségével, főkomponenselemzéseljárással hoztuk létre a kutatás első szakaszában elkészült elemzésekhez. Ezt követően ugyanazon változók alkalmazásával egy szummatív skálát is kialakítottunk a szubjektív életminőség mérésére az összevont adatokon tervezett többváltozós elemzések elkészítéséhez. A kétváltozós elemzések körében első lépésben megvizsgáltuk a többdimenziós életminőség indikátor elemeinek jellemzőit és viselkedését a két mintában, leíró elemzés keretében. Második lépésben a kialakított multidimenzionális mérőeszköz alapján a lakosság szubjektív életminőségének alakulását elemeztük a két időszakban, az egyes társadalmi-demográfiai csoportok mentén, a társadalmi átlagtól való eltérés alapján. Ezt követően a hipotéziseket 
többváltozós statisztikai elemzés útján, regressziós eljárásokkal, a legkisebb négyzetek módszerével teszteltük, mely során nem a standardizált, hanem a standardizálatlan regressziós együtthatókat értékeltük.

A kutatás föbb eredményeit összefoglalva elmondhatjuk, hogy a lakosság 2012-ben mért átlagos szubjektív életminősége valamelyest szignifikánsan csökkent a 2006-os időszakhoz viszonyítva, azonban az összetételi hatások kiszürését követően a mért különbség már nem volt szignifikáns. Tehát a válság hatását, mint periódushatást az adataink nem támasztották alá. A gazdasági válság éveiben azonban szignifikánsan nőtt az egyéni anómia- és elidegenedésérzet elterjedtsége a magyar lakosság körében. Továbbá, eredményeink igazolták, hogy az egyedülállókhoz képest a házasságban vagy törvényes élettársi kapcsolatban élők mind a válság előtti időszakban, mind a kilábalás éveiben kedvezőbb szubjektív életminőséget értek el. Azonban a válságot követően a házasok (törvényes élettársi kapcsolatban élők) és az egyedülállók életminőségbeli különbsége 2006-hoz képest nem mutatott szignifikáns eltérést. Az adataink szerint a munkaerő-piacon jelenlévők a recesszió éveiben átlagosan alacsonyabb életminőségről számoltak be, jóllehet a válság éveiben a dolgozók és nem dolgozók csoportjainak életminőségbeli különbsége is megnőtt. Bizonyítást nyert továbbá az is, hogy a jó szubjektív egészségi állapottal rendelkezők és az anyagi gondok nélkül élők átlagosan kedvezőbb jóllétszintet realizálhattak a válságot követően is, szemben azokkal, akik rossznak vagy nagyon rossznak értékelték egészségüket, illetve nehezen vagy nagyon nehezen jöttek a ki a jövedelmeikből; azonban a két időszak összetésében a csoportok szubjektív életminőségében mért különbségek nem mutattak szignifikáns eltéréseket. Azok, akik a lakókörnyékükkel kapcsolatosan biztonságérzetről számoltak be, a válságot követően is kedvezőbb életminőségről adtak számot, mint a biztonsághiányt érzékelő társaik. Az elemzések rámutattak továbbá, hogy az optimista beállítottságú egyének mindkét időszakban az átlagostól jóval kedvezőbb szubjektív életminőséget értek el. A válságot követően azonban az optimisták és pesszimisták átlagos életminőségbeli különbségei megnőttek, mely divergencia a pesszimisták romló, a jövőbe bizakodóan tekintő lakosok javuló indexpontszámainak együttes hatásaként jelentkezett. 
Összefoglalóan elmondhatjuk, hogy a gazdasági válság éveiben a lakosság szubjektív életminsőségét a demográfiai tényezők közül az életkor erősebb, a családi státusz gyengébb összefüggés mellett határozta meg. Ez utóbbit fentebb említettük, az életkor esetében pedig azt láttuk, hogy elsősorban a 30 év alattiak életminősége volt a legkedvezőbb, hozzájuk viszonyítva az 50-59 évesek és a 70 év felettiek jóllétszintje volt átlagosan a legkedvezőtlenebb a válságot követően. A további indikátorok esetében, láttuk, hogy a jó vagy rossz szubjektív egészségi állapot, a biztonságérzet, a mindennapi anyagi gondok jelenléte vagy hiánya, az anómia és elidegenedésérzet jelenléte, illetve az optimista szemlélet szignifikánsan meghatározták a lakosság életminőségét. Azonban a 2006-os évhez viszonyítva 2012-ben, a válság hatásaként értelmezhető pozitív vagy negatív irányú, a dichotóm társadalmi nagycsoportok életminőségbeli különbségeiben mért szignifikáns eltérést egyedül a 'dolgozik - nem dolgozik' és az 'optimista - pesszimista' csoportoknál mérhettünk csupán, mindkét esetben a nagycsoportok divergenciája mellett.

\subsection{A dolgozat felépítése}

A dolgozat 2. fejezetében a kutatás szakirodalmi hátterét, az elméleti koncepciókat és a kutatási előzményeket tekintjük át, melyek a hipotézisek megfogalmazásához elvezettek. Elsősorban az életminőség vizsgálatok elmúlt 40 évének - a kutatáshoz kapcsolódó - lényeges makro- és mikro megközelítéseiről és empirikus vizsgálatairól, mint kutatási előzményekről adunk számot. A disszertáció 3. pontjában meghatározzuk a kutatás hipotéziseit, majd a 4. fejezetben a vizsgálat módszertani kereteit fogalmazzuk meg, bemutatjuk vizsgálatunk módszereit, majd az elemzés változóit operacionalizáljuk. Az 5. fejezetben az eredményeket prezentáljuk, mely során a megfogalmazott hipotéziseinket verifikáljuk illetve falszifikáljuk. A dolgozat 6. pontjában megválaszoljuk a kutatás kérdéseit, végül pedig a dolgozat tudományos eredményeit foglaljuk össze, melyet követően említést teszünk a kutatásunk gyengeségeiről, majd a lehetséges további kutatási irányokat jelöljük ki. 


\section{Elméletek és kutatási előzmények}

A szubjektív életminőség és jóllét elméleti és kutatási előzményeit bemutató fejezetben egyrészt rövid áttekintést kívánunk adni a társadalmi jelzőszámok és indikátorok fejlődéstörténetéről, tekintettel arra, hogy kutatásunkban a kidolgozásra kerülő többdimenziós indikátorral magunk is az indikátorok körét kívánjuk bővíteni. Tesszük ezt azért is, mert koncepciónkban egy régi modellhe nyúlunk vissza, mely alapját képezi a vizsgálatunkhoz kifejlesztett többdimenziós életminőség mutatónknak. Másrészt, kutatásunkban nem egy korábbi elméletet kívánunk tesztelni, vagy egy statisztikai modellhez kapcsolódó speciális kérdést igyekszünk megválaszolni, hanem általánosságban, a magyar lakosság, illetve az eltérő társadalmi nagycsoportok életminőségbeli változásait kívánjuk vizsgálni a gazdasági válságot követően. Ugyanakkor, tekintettel arra, hogy egy régi megközelítést választottunk kiindulópontként, a szubjektív jóllét kutatástörténetét is bizonyos megszorításokkal nyomon kívánjuk követni. Ezért mind az általánosabb problémafelvetés, mind a történeti áttekintés a szokásostól eltérően más tematikára épülő szakirodalmi bemutatással jelenik meg, melynek okán a következő alfejezetben az elméleti megközelítések mellett olyan irodalmakat is bemutatunk, amelyek a gazdasági válság életminőségre kifejtett hatásának a vizsgálatához közvetetten kapcsolódnak.

\subsection{Az életminőség mérése - társadalmi jelzőszámok, indikátorok}

Az 1960-as években az 1 före jutó GDP, vagy GNP már nem bizonyult alkalmas mérőeszköznek a nemzetek társadalmi-gazdasági fejlödésének, a lakosság életkörülményeinek mérésére. Ezért a társadalomtudósok olyan új indikátorok kidolgozását tüzték ki célul, mely a közgazdaságtani mutatók mellett az életkörülményeket az egyének szubjektív értékelése alapján mérte. Az amerikai „életminőség” (quality of life) koncepció, mint individuális jóllét, a különböző életszükségletekkel való egyéni elégedettségi értékelések összetevői alapján mérhető fogalomként került meghatározásra, melynek nyomán a fejlett országok statisztikai rendszereibe az objektív indikátorok mellett a lakosság szubjektív jóllétét mérő 
egyéni elégedettségi mutatók is bevezetésre kerültek (Bukodi, 2001; Zapf, 1980, 2000). Ezt a folyamatot a szakirodalom az ún. „társadalmi jelzőszám mozgalomként” (social indicators movement) aposztrofálta, amely az Amerikai Egyesült Államokbó1 az 1960-as években indult el, és a hetvenes évekre terjedt át Európába. Európában két irányzat vált jelentőssé, a skandináv és a német iskola, melyeket eltérő koncepciók és megközelítések alapoztak meg. A skandináv indikátorrendszer megújításában többek között Erik Allardt játszott meghatározó szerepet. Allardt a hetvenes években a négy skandináv állam összehasonlító jólét-vizsgálatának eredményeként az életminőségnek egy átfogó teóriáját dolgozta ki. A nevéhez füződő megközelítés Maslow (1943) alapvető szükségletek elméletére épült. A teória szerint az embernek ötféle szükséglete van: fiziológiai, biztonsági, szeretet-, megbecsülés- és önmegvalósítási szükségletek, melyek hierarchikusan helyezkednek el és nyernek kielégítődést. Allardt számos objektív és szubjektív indikátor alapján levezetett feltáró elemzése három dimenzió körülhatárolását tette lehetővé, amelyeket a jólét három fö komponenseként az élet alapvető szükségleteiként határozott meg. Koncepciójában a jólét anyagi oldalát a materiális szükségleteket átfogó „Having” dimenzió ragadta meg, és az egyének objektív anyagi helyzetét fejezte ki a jövedelem, a háztartás lakósürüsége, a vagyoni helyzet alapján. Az immateriális oldalt egyrészt a szociális szükségleteket átfogó 'Loving' dimenzió képezte, mely a barátság, a szeretet, a szolidaritás és az összetartozás (kölcsönös törődés és támogatás) értékeit kapcsolta össze. A szolidaritás fogalmi keretét azonban a szerző nem tágította ki a politikai és nemzeti szolidaritás koncepcióinak területére. E dimenzió fő kategóriái a következők voltak:

- az egyén kapcsolathálózatokba való beágyazottsága (,loving”),

- biztonság- és támogatottság érzése (,,felt security and support”),

- szabadsága a személyes életre vonatkozó döntésekben (,,freedom of choice”),

- és boldogságérzete (,,perceived happiness”) (Allardt, 1973:10-22).

Az immateriális oldalt másrészről pedig a 'Being' dimenzió alkotta, amelyben a személyes fejlődés, az önmegvalósítás vagy önkiteljesedés fogalmai kapcsolódtak össze. Az önmegvalósítás ebben az értelemben azt jelentette, hogy az egyén a családi, baráti és a munkahelyi közösségekben fontosnak érzi magát, és úgy érzi, olyan képességekkel rendelkezik, amelyek miatt számítanak rá, és nélkülözhetetlen tagja 
ezeknek a csoportoknak. Lényeges elemei e dimenziónak az új dolgok megtanulásának lehetősége és az egyén részéről jelentkező igény speciális képességek elsajátítására, továbbá a közéleti tevékenységekben való részvétel, illetve bizonyos szabadidős tevékenységek melletti elköteleződés. A dimenzió egyes kategóriái tehát, amelyeket itt is több itemmel mért a szerző, a következők voltak:

- a helyettesíthetőség érzésének hiánya (,,insubstitutability”),

- a személyes fejlődés lehetősége (,self-development”),

- és a köz- és magánéleti tevékenységekben való részvétel (,,doing”) (Allardt, 1973:13-19).

Allardt, ahogyan a bevezetőben említésre került, részletesen nem foglalkozott kutatásában a feltáró faktorelemzése alapján kirajzolódó többi dimenzióval. A három fö szükségletdimnezió mellett azonban lényegesnak tartotta tanulmányában kiemelni a jóllét pozitív érzései mellett a negatív emóciókat, melyeket két fó csoportba sorolt: (i) különböző panaszok, frusztrációk, (ii) nyugtalanság. A nyugtalanságot mérő indexet több olyan kérdéssel hozta létre, amelyek legtöbbje ma a depresszió skálákban a mentális állapotok mellett a fizikai tüneteket (pl. erős szívdobogás) is mérik. Ezen indikátorok bemutatásától itt eltekintünk, azonban fontosnak tartjuk kiemelni, hogy Allardt koncepciójában a tartós érzelmet megragadó „boldogság” kérdése mellett, az eltérő pozitív vagy negatív tartalmú, időszakos érzelmi állapotokat mérő mutatók is jelentős szerepet képviseltek. Tekintettel arra, hogy a tartós és időszakos emóciókat mérő változók nem helyezkedtek el egy önálló faktoron, ezért ezeket külön nem nevesítette a szerző, összességében a jólléthez kapcsolódó érzelmekként utalt rájuk (,,feelings of well-being”) (Allardt, 1973: 2328). Allardt későbbi munkájában kidolgozta a fö szükségletdimenziók objektív mutatóinak egyéni értékelésen alapuló, egyszerüsített rendszerét, melyben a Having dimenziót az életkörülményekkel való elégedettség, a Loving dimenziót a kapcsolatokkal való elégedettség, míg a Being dimenziót a személyes önmegvalósítás mértékével való elégedettség szubjektív indikátorai képezték le (Allardt, 1993).

A társadalmi jelzőszám mozgalom hullámai Magyarországot is elérték a hetvenes évek elején. A nemzeti indikátorrendszer kidolgozása Andorka Rudolf vezetésével a Nemzeti Statisztikai Hivatalban vette kezdetét (Andorka-Kulcsár, 
1975a, 1975b). E korai időszakban, hazánkban az életkörülmények mennyiségi, objektív mutatóinak rendszerezésén volt a hangsúly. A társadalmi jelzőszámmozgalomnak köszönhetően, a '80-as évek végétől, a rendszerváltozás időszakától kezdődően viszont előtérbe kerültek a szubjektív indikátorok. Andorka szubjektív jólléttel kapcsolatos vizsgálatai az életminőség koncepciójának allardti modelljén, az ún. szubjektív elégedettségi mutatókból kidolgozott megközelítésen alapultak. A szubjektív jóllét materiális oldalát (a „having” dimenziót) az anyagi életkörülményekkel való elégedettséggel, míg annak immateriális aspektusát a „being” és a „loving” komponensek együtteseként, a boldogság kérdésével mérte (Andorka, 1996).

Kutatásunk a magyar lakosság szubjektív életminőségének vizsgálatát állítja a középpontba, amelyet a szakirodalomban eltérő koncepciók mentén, eltérö módszerek alkalmazásával elemeztek. Azonban vizsgálatunkban nem egy korai teória újratesztelésére vállalkoztunk, annak érdekében, hogy feltárjuk, vajon működik-e a modell a 2000-es években, vagy sem. Sokkal inkább a 2008-ban bekövetkezett gazdasági válság hatásának vizsgálatához megfelelő szubjektív életminőség-modell kialakítását céloztuk meg. Ehhez Allardt fentiekben bemutatott „Having-Loving-Being” szubjektív modelljét választottuk, amelynek három fó dimenziója mellé az egyéni jóllét tartós és rövid távú érzéseivel egy multidimenzinális szubjektív életminőség indikátort hoztunk létre. A következőkben az allardti modell alkalmazásának a priori jellege mellett néhány érvet sorakoztatunk fel.

A gazdasági válságok idején, ahogyan a bevezetőben a makrofolyamatok bemutatásra kerültek, a háztartások racionalizálták kiadásaikat, a családok kevesebbet költöttek az egészségük megörzésére, a szabadidejük aktív eltöltésére, de sok esetben a fiatalok a tanulmányaik folytatását is szüneteltették, vagy megszakították anyagi okok miatt (European Commission, 2014). Láttuk, hogy a válság időszakában a jövedelemegyenlőtlenségek 2012-ig növekedtek, és szintén nőtt az anyagi depriváció elterjedtsége a lakosság körében (Szivós-Tóth, 2013, 2015), a reálfogyasztás szintén 2013-ban kezdett el növekedni. A recesszió időszakában tehát az alapvető szükségletek realizációja vált hangsúlyossá és került előtérbe az egyének életében. Ugyanakkor láttuk azt is, hogy a válságból való kilábalás éveiben 
a szükösebb életkörülmények, a megnövekedett bizonytalanság és kiszolgáltatottságérzet több stresszt, félelmet és frusztrációt hozott az emberek mindennapjaiba (Eurobarometer, 2014). A válság időszakát elemző írások közül több is rámutatott a támogató kapcsolatok kiemelt szerepére a mindennapi nehézségek leküzdésében, a recesszió kedvezőtlen hatásának mérséklésében (Cummins-Wooden, 2014; Cummins et al., 2014; Helliwell et al., 2014; European Commission, 2014; Gudmundsdottir et al., 2016). Továbbá empirikus eredmények már korábban is igazolták, hogy a személyes fejlödés, az intellektuális növekedés a modern társadalmakban sokkal inkább hozzájárul a szubjektív jóllét javításához, mint az anyagi siker (Ryan et al., 1999), az emberek az idejük feletti rendelkezést és az önmegvalósítás igényét életük minőségének legalább olyan lényeges aspektusának tartják a késő modernkori társadalmakban, mint az anyagi javakkal való ellátottságot (Garhammer, 2002; Blanchflower-Oswald, 2011). Összességében tehát a fenti érvek alapján az alapvető szükségleteken alapuló allardti modellt, a válság kedvezőtlen hatásaira érzékeny modellként, kutatási koncepciónk alapján kialakítva, megfelelőnek tartjuk a lakosság szubjektív életminőségének vizsgálatára.

Továbbá, munkánk során figyelembe kívánjuk venni a finn társadalomtudományi kutatómühelyekben kialakult, az allardti having-loving-being modell átdolgozására irányuló törekvéseket, amelyet láthattunk Hirvilammi-Helne (2014) munkájában. A tanulmányban a kutatók a fenntartható jóllét koncepcióját dolgozták ki, amelynek alapja az allardti modell volt. A három fó szükségletdimenzió mellé negyedikként a szerzők a Being dimenzió egy kategóriáját, az Allardt által „doing”-nak rövidített, szintén több indikátorral mért köz- és magánéleti tevékenységet emelték ki. Tették mindezt azért, mert koncepciójuk szerint a 'fenntartható jóllét' megteremtésének lényeges eleme úgy a közéleti tevékenységekbe történő aktív bekapcsolódás, mint a személyes élet különböző területein megvalósuló cselekvés. A 'having-loving-doing-being' modell megszületését a '80-as évek óta lezajlott társadalmi-gazdasági változások nyomán kidolgozott fenntartható fejlődés elméletnek, mint új paradigmának a kialakulása hívta életre. Jelen kutatás során, megtartva szintén a három alapvető dimenziót, a korai allardti modellben a Loving faktoron elhelyezkedő boldogságérzetet, mint tartós emóciót, és a többi faktoron elszórtan elhelyezkedő, pozitív és negatív 
időszakos érzéseket emeltük ki a kutatási koncepciónk alapján, melyet maga Allardt nem kezelt önállóan.

A tartós és átmeneti érzések kiemelését kettő tényező indokolja: egyrészt az a tény, hogy az eltérő tartamú érzések a szubjektív jóllét kutatásának kezdete óta a jóllét affektív oldalaként (affective well-being) kerültek meghatározásra (Diener, 1984), melyet a tartós érzületként definiált globális boldogságérzet és az időszakos pozitív és negatív érzések együttesen határoznak meg. E fogalom a jóllét kognitív oldalával, az élettel való elégedettséggel együtt alkotja a szubjetív jóllét koncepcióját. Azonban, azt is láttuk egyrészt, hogy a jóllét érzelmi és racionális oldalának különbözősége bizonyítást nyert, bizonyos átfedések mellett (Luhmann et al., 2012), vagyis az élettel való elégedettséget nem helyettesítheti a globális boldogságérzet indikátora, másrészt láttuk azt is, hogy a boldogság (happiness) nem egyenlő az egyéni jólléttel (Raibley, 2012), tehát mindhárom tényező empirikusan igazoltan, önálló konstruktumot alkot. Továbbá, ahogyan arra empirikus vizsgálatok szintén rámutattak, az időszakos érzéseket illetően, azok közül elegendő a főbb, általánosabb érzések gyakoriságának mérése (öröm-szomorúság; nyogodtság-nyugtalanság), tekintettel arra, hogy azokon túli, tovább érzés-típusokat az egyének ritkábban élnek meg (Diener et al., 2010). Tehát az általunk kiemelt, az allardti modellben a faktorokon elszórtan elhelyezkedő érzelmi tényezőket kutatásunkban, külbözőségük okán, önállóan vesszük figyelembe. Nevezetesen az individuális jóllét affektív aspektusaként egyrészt a tartós érzületet kifejező boldogságérzetként, másrészt pedig a rövid távú érzések egyenlegét kifejező érzelmi balanszként. Az életminőség átfogó koncepcióját nyújtja továbbá Cummins objektív és szubjektív indikátorokból képzett átfogó életminőség modellje (a modell részletes bemutatását lásd az F.1 Függelékben.) Az életminőség fö tényezői itt is a Having, Loving, Being dimenziók mentén csoportosíthatók (Cummins, 1993, idézi: Veenhoven, 2000), melyek a korai allardti modell jelentőségét szintén megerősítik.

A társadalmi jelzőszám mozgalom tehát éltre hívta az objektív vs szubjektív indikátorok problematikáját a tudományos diskurzusban. A skandináv kutatói mühelyben Robert Erikson és Joachim Vogel nevét szükséges megemlítenünk, akik az allardti elképzeléssel szemben más felfogást képviseltek a jólét mérését illetően. Erikson jóléti koncepciója egyértelmủen az objektív indikátorokra korlátozódik. 
Véleménye szerint az élettel való elégedettség, vagyis az egyén szubjektív értékelése nem alkalmas arra, hogy társadalmi egyenlőtlenségeket mérjen. Az egyenlőtlenség abból adódik meglátása szerint, hogy a társadalom eltérő csoportjai eltérő mennyiségü javakkal (erőforrásokkal) rendelkeznek, azonban a szubjektív értékeléseket az egyének aspirációi befolyásolják, így azonos erőforrás ellátottság is eredményezhet nagyon eltérő szubjektív vélekedéseket az egyéni jóllétre vonatkozóan. Erickson koncepciója alapján az objektív mutatókkal mérhető erőforrásokkal (,anyagi javak: jövedelem, vagyon; egészség; tudás: iskolai végzettség; társadalmi tőke: családi, baráti kapcsolatok") való ellátottság az, ami alkalmas az eltérő társadalmi csoportok összehasonlítására és a jólét mérésére (Berger-Schmitt \& Noll, 2000:9). Vogel alapvetően egyetértett Erikson megállapításaival, azonban a '90-es évek második felétől kezdődően elérkezettnek tartotta az időt az indikátorrendszer tartalmi újragondolására. Tanulmányában javaslatokat is tett erre vonatkozóan, így például fontosnak tartotta „a globalizáció problémáinak, a túlzott piaci versenynek, a munkahelyek megszünésének, a jóléti kiadások megnyirbálásának, a foglalkoztatás, a jövedelem és a közszolgáltatások bizonytalanságának mérésére alkalmas jelzőszámok” kidolgozását. Továbbá olyan indikátor kimunkálását, amelyek a „társadalmi kirekesztés, dezintegráció, szegénység és egyenlőtlenség” jelenlegi problémáinak mérésére alkalmasak lehetnek, és lehetőséget biztosítanak mélyebb társadalompolitikai elemzések elkészítéséhez (Vogel, 1997:110-111).

A bevezetőben már említett másik nagy európai szellemi mühely a német iskola volt, amelynek meghatározó alakjai közül elsősorben Wolfgang Zapf, Roland Habich és Heinz-Herbert Noll nevét szükséges említeni. A német indikátorrendszer az ún. SPES Social Indicators System néven vált ismertté, és Wolfgang Zapf nevéhez köthető. Zapf (1980) és munkatársai az OECD programját vették alapul rendszerük kidolgozásához, amelynek lényege a ,,social reporting”. A koncepció a társadalom folyamatos monitorozását jelenti a döntéshozók számára a társadalompolitikai célkitűzések megvalósításának ellenőrzése érdekében. Azonban a ,social reporting” elképzelését Zapf egy tágabb jólét értelmezési keretnek tartotta, mint a társadalmi jelzőszám mozgalom gondolatát. Amíg ezen utóbbit csupán társadalmi statisztikáknak, addig az előbbit az életkörülmények és a szubjektív jóllét 
kérdésein alapuló társadalompolitikai elemzéseknek tekintette (Zapf, 2000:8-9). A német indikátorok kidolgozásának elmélyítését szolgálta Noll (2002) jóllét-elmélete, amelyben az életkörülmények és az elégedettség négyes mátrixát dolgozta ki a szerző. A modell négytípusú élethelyzetet definiált, mely szerint az elsőben a kedvező életkörülményekhez egyéni szintű elégedettségérzet kapcsolódik, amelyet „well-being”-ként határozott meg. A szintén kedvező körülmények melletti elégedetlenségérzetet disszonanciaként, a kedvezőtlen életkörülményeket és az egyéni elégedetlenséget deprivációként aposztrofálta. Azonban teóriájában azt az esetet, amikor a rossz életkörülményekkel az egyén elégedett volt, adaptációként vevesítette, ami a rossz életfeltételekhez való alkalmazkodást jelentett.

Az ezredfordulóra az európai jólétvizsgálatok és a „social reporting” programjai kibővültek azzal az Euromodul néven ismertté vált adatfelvétellel, amely Wolfgang Zapf és Roland Habich irányításával indult el 1999-ben nyolc országban, köztünk hazánkban is Spéder Zsolt vezetésével. Az Euromodul ugyanazon célokat maga elé tüzve, elsőként vizsgálta az életminőség szubjektív oldalát - az elégedettség és boldogság egyitemü kérdései mellett - több kérdésen keresztül, mellyel túlmutatott a korábbi nemzetközi vizsgálatokon (Eurobarometer, World Value Survey) (Bukodi, 2001; Hegedűs, 2001). A kutatási program elméleti kerete kettő koncepciót foglalt magában: az életminőség (quality of life) és a társadalomminőség (quality of society) teóriáját. Az elöbbiben az életminőséget az objektív életkörülmények és a szubjektív jóllét fogalmai definiálták. A szubjektív jóllét elmélete itt az egyéni értékelés kognitív és affektív oldalait különböztette meg, amelyben elöbbit az élet egyes területeivel való elégedettséggel, utóbbit a boldogságérzet mérésével operacionalizálták. A társadalom minősége magában foglalta a társadalmi tőke, a társadalmi kohézió, a társadalmi kizárás és az új típusú szegénységi formák koncepcióit, melyek az „,(1.) érzékelt társadalmi konfliktusok (pl. gazdagok és szegények között, munkával rendelkezők és munkanélküliek között), (2.) a másik emberbe vetett bizalom, (3.) a szabadságérzet, (4.) a közbiztonság és (5.) a társadalmi igazságosság" fogalmai mentén kerültek kialakításra (Delhey et al., 2002:173). Az európai integrációs folyamatok a kutatási programok sorát tovább bővítették. Az EuReporting Projekt az uniós tagállamok tekintetében egy teljes mértékben összehangolt, egységesített mutatórendszert alkalmazott. A projekt célja 
az uniós politikák és célkitüzések megvalósításának, a jóléti társadalmak folyamatos fejlődésének társadalomstatisztikai adatgyüjtésen alapuló kiértékelése volt. A német iskolához tartozó Berger-Schmitt és Noll szerzőpáros dolgozták ki ezen átfogó európai indikátorrendszer elméleti keretét. Az európai jólét-koncepció alapjául a korábbi tudományos viták megközelítései szolgáltak, úgy mint a „quality of life” koncepció, a társadalmi kohézió vagy a fenntartható fejlődés elméletei. Az általuk kidolgozott átfogó jólét értelmezési keret magában foglalta „az objektív életkörülmények javítását, a szubjektív jóllét növekedését, továbbá az egyenlőtlenségek csökkentését, a lehetőségekhez és társadalmi részvételhez való egyenlő hozzáférés biztosítását, a társas-társadalmi kapcsolatok megerősítését, a természeti erőforrások, az emberi és társadalmi tőke megóvását és felhalmozását a jövő generáció számára”. E tényezők és összetevők azok, amelyek a szerzők szerint együttesen határozzák meg az élet minőségét (Berger-Schmitt\&Noll, 2000: 41).

Az európai társadalmi jelzőszám-rendszer továbbfejlesztésére tett kísérletek az ezredfordulót követően is folytatódtak. Mérföldkőnek számított a 2009-ben megjelent „Stiglitz-Sen-Fitoussi Report” néven ismertté vált javaslat, melyet azonban a korábbi fejlesztésekben meghatározó szerepet játszó szakértők eltérően értékeltek, tekintettel arra, hogy az életminőséghez kapcsolódó több megközelítést és mutatót figyelmen kívül hagyott a jelentés (Noll, 2011). Magyarországon bizonyos értelemben mindkettő, a német és a skandináv szellemi áramlat is kifejtette hatását, a fent említett Euromodul kutatás eredményeit több helyen is idézzük dolgozatunkban (Spéder, 2000), azonban számos kutatást az allardti elmélet alapozott meg. Allardt és Andorka hagyományait, tehát a szubjektív jóllét 'having-loving-being' koncepcióját követte az egyéni életminőség kutatása terén Spéder és Kapitány (2002). A kutatók az individuális jóllét magyarázatára objektív és szubjektív mutatók összevont modelljében tettek kísérletet, külön vizsgálva az életszínvonallal, mint a jólét anyagi összetevőjével való elégedettséget és külön a boldogságot, mint az élettel való globális elégedettséget. A szerzők az objektív körülményeket mérő változók (életkor, iskolai végzettség, foglalkoztatotti helyzet, ekvivalens jövedelem, vagyoni helyzet) és az egyén szubjektív érzéseit kifejező mutatók (anómia-index, státuszfeszültség, egészséggel való elégedettség) együttes hatásait vizsgálták. Tanulmányukban megállapították, hogy az életszínvonallal kapcsolatos elégedettségre az objektív 
változók közül elsősorban a vagyoni index, kisebb mértékben az életkor, míg a szubjektív változók közül a státuszfeszültség fejt ki lényeges hatást. A globális elégedettségérzésnek, a boldogságnak a meghatározásában viszont az objektív változók befolyása elenyésző volt, szemben a szubjektív mutatókkal, amelyek mindegyike lényeges szerepet játszott az egyéni jóllét alakulásában.

\subsection{A szubjektív jóllét elméleti megközelítései és kutatási előzményei}

A szubjektív jóllét kutatási területének mind tudománytörténeti, mind kutatásmódszertani fejlődési folyamatát három fő szakaszra osztotta Diener és Biswas-Diener (2000).

(1) A korai kutatások az élettel való elégedettséget és a boldogságérzetet egy egyszerü, egyitemes kérdésre támaszkodva mérték, és a szocio-demográfiai változók (nem, életkor, iskolai végzettség, életszínvonal, jövedelem, vagyoni helyzet) szerinti csoportátlagokat ismertették és hasonlították össze. Több kutatásból láthatóvá vált, hogy a demográfiai változók a szubjektív jóllét varianciáját csekély mértékben magyarázzák. A vizsgálatok ugyanakkor nem világítottak rá az eredmények mögötti strukturális okokra, társadalmi mechanizmusokra.

(2) A második szakaszban a szubjektív jólléthez kapcsolódó teóriák sokasodtak meg, melyekkel együtt a mérőeszközök is fejlödtek. Az egyitemü kérdéseket felváltották a többdimenziós mérőeszközök, mint az élettel való elégedettséget mérő skála (Life Satisfaction Scale), melyet öt indikátor összetett mutatójaként alakítottak ki. Az összetett skálák gyakran affektív itemeket is magukban foglaltak, ezért az egyéni jóllét racionális oldalának mérése bizonyos értelemben -egyes összetett mérőeszközök esetében- kérdésessé vált (lásd ehhez a 2. sz. Függeléket). Továbbá az egyitemü boldogság kérdését szintén felváltották többitemü mutatók, mint például az ún. Oxford Boldogság Index.

(3) A harmadik szakaszban a kutatók vizsgálataik során többféle mérőeszközt és módszertani eljárást alkalmaztak, finomabb elemzési technikákat vezettek be, amelyeket paneladatokon is teszteltek. Ezek rávilágítottak az egyes mérések 
közötti különbségekre, a korábbi elméletek gyengéire, és olyan oksági modelleket igyekeztek konfirmálni, melyek az egyéni jóllétet meghatározó, eddigiekben figyelmen kívül hagyott társadalmi jelenségekkel is kapcsolatosak voltak.

Az első időszakot érintve Andrews és Withey (1974) korai munkáját emeljük ki, melyben a szerzők arra tettek kísérletet, hogy meghatározzák, milyen tényezőket kell figyelembe venni ahhoz, hogy a szubjektív jóllét összetételét és mértékét országos szinten lehessen mérni. A szerzők által kidolgozott kérdőívben számos, a szubjektív jólléthez tartalmilag kapcsolódó kérdést tettek fel. Nevezetesen, hogy melyek lehetnek az egyéni jóllét összetevői, ezek az elemek hogyan kapcsolódnak egymáshoz, hogyan változnak az időben előre haladva, illetve különböző társadalmi és földrajzi csoportoknál. Természetesen mind objektív, mind szubjektív indikátorokat figyelembe vettek, s végül egy 123 itemből álló listát kaptak. Ezt a listát mind helyi, mind országos adatfelvételekben lekérdezték. Az empirikus teszteredményeket összegezve két megközelítést dolgoztak ki a jóllét meghatározására. Az egyik „fentről-lefelé”, míg a másik „lentről-felfelé” határozta meg az életről alkotott értékelés irányát. Az előbbi megközelítés szerint az embereknek az életükkel való általános elégedettség érzése az, ami meghatározza, hogy mennyire elégedettek az életük egyes területeivel (top-down approach). Míg az utóbbi szerint a munkával, az egészséggel, a lakókörnyezettel, a jövedelemmel és más életterületekkel (life domains) való elégedettség együttesen alakítja ki azt, hogy általában az emberek mennyire elégedettek összességében az életükkel és mennyire boldogok (bottom-up approach). A szubjektív életminőség fentiekben már említett észak-amerikai koncepciója alapján a szubjektív jóllét (subjective well-being) fogalmát Ed Diener (1984) határozta meg, akit már a bevezetőben is említettünk. Teóriájában az egyéni jóllétet kettő összetvevővel definiálta: a viselkedés racionális, intellektuális oldalaként az élettel való elégedettséggel, illetve az attitűd érzelmi, emocionális összetevőjeként a boldogsággal (2. táblázat). Az összetett modell a szubjektív jóllét aspektusait már önálló jóllét fogalmakként határozza meg. Míg az érzelmi jóllét (affective well-being) fogalomkörébe az egyén egész életét átfogó, tartós érzületként definiált boldogságérzet kiegészül az időszakos pozitív érzések jelenlétével és a szintén átmeneti negatív percepciók hiányával, addig a kognitív 
jóllét (cognitive well-being) továbbra is az élettel, az élet egészével való elégedettségnek az értékelését fejezi ki (3. táblázat).

2. táblázat: A szubjektív jóllét egyszerü modellje*

\begin{tabular}{|c|c|}
\hline \multicolumn{2}{|c|}{ szubjektív jóllét } \\
\hline kognitív oldal & affektív oldal \\
\hline élettel való elégedettség & boldogság \\
\hline
\end{tabular}

*Forrás: Diener, 1984.

3. táblázat: A szubjektív jóllét összetett modellje*

\begin{tabular}{|c|l|c|c|}
\hline \multicolumn{3}{|c|}{ szubjektív jóllét } \\
\hline kognitív jóllét & \multicolumn{3}{|c|}{ affektív jóllét } \\
\hline élettel való elégedettség & boldogság & pozitív érzések & $\begin{array}{c}\text { negatív érzések } \\
\text { hiánya }\end{array}$ \\
\hline
\end{tabular}

*Forrás: Diener, 1984, 1994

Észak-Amerikában már az 1950-es évektől vizsgálták különböző marketing kutatások kapcsán a fogyasztói magatartást és ahhoz kapcsolódva az emberek időfelhasználását. Az első olyan komolyabb munka, melyben az időfelhasználás módja összekapcsolódott az életminőség kérdésével Dow és Juster (1985) kutatása volt, melyet itt azért mutatunk be, mert az átmeneti, időszakos emóciók szerepére tanulmányuk egyértlemüen rávilágít, amellyel saját kutatási koncepciónkat ismételten alátamsztani kívánjuk. Munkájukban Dow és Juster egy egységesített elméleti keretet állítottak fel annak érdekében, hogy mind a piaci és mind a nem piaci tevékenységek időfelhasználásának jóllétre kifejtett hatását elemezzék. Szerintük minden ember fontossági sorrendet állít fel a különböző tevékenységei között, és ezek a preferenciák befolyásolják, hogy az emberek hogyan osztják be az idejüket, tehát milyen időfelhasználási módot alakítanak ki maguk számára. Ez az időfelhasználási mód pedig befolyásolja a jóllétüket, az élettel való elégedettségüket. Mindezt úgy mérték, hogy megkérték a válaszadókat, hogy az általuk felsorolt 22 féle tevékenységet értékeljék abból a szempontból, hogy az mennyire élvezetes a számukra. Az így kapott pontokat megszorozták minden egyes tevékenységre 
fordított időmennyiséggel, és azt minden egyes válaszadó esetében összegezték. Majd megvizsgálták az élettel való elégedettség és ezen indikátoruk kapcsolatát. Az eredmények azt mutatták, hogy az egyes tevékenységek elvégzésével járó öröm kis mértékben befolyásolta az élet minőségével való általános elégedettséget. Tehát a jóllét mértéke nem volt levezethető az élvezetes tevékenységekkel töltött idő allokációjából. A különböző kontrollváltozók alkalmazása sem vezetett eredményre, mert amíg a házasság az élettel való elégedettséggel pozitív kapcsolatban állt, addig az élvezetes tevékenységeket allokáló mutatóval negatív összefüggésben. Továbbá amíg az életkor, a nem, a munkaerő-piaci státusz, a gyermek léte nem volt hatással az élettel való általános elégedettségre, addig a kutatásban kifejlesztett allokált indikátorral mindegyik pozitív kapcsolatban állt (Dow-Juster, 1985:410).

Garhammer (2002) tanulmánya, melyben az időhiány (time pressure) és a szubjektív jóllét közötti összefüggést vizsgálta, már a második szakaszhoz kapcsolódik. Európai uniós országok adatait elemezve, és azokat az USA és Japán adataival összehasonlítva Garhammer nem várt eredményekre jutott, nevezetesen arra, hogy az felgyorsult élettempó mellett nem csökkent sem az élettel való elégedettség mértéke, sem a boldogságérzet. Ellenkezőleg, a legaktívabb életet élő emberek voltak azok, akik a legnagyobb boldogságról számoltak be. Ez az összefüggés pedig megállta a helyét mind az országok közötti összehasonlításban, mind individuális szinten. Az eredmények interpretálásához két elméletet hívott segítségül a szerző. Egyrészt a modernizációs elméletet, mely szerint a gazdasági növekedés magával vonta az élettel való elégedettség és az életminőség javulását. Ez a folyamat pedig egy intenzívebb társas-társadalmi életet indukált, mely az időhiány negatív hatásait kiegyenlítve egy intenzív kikapcsolódással járó életformát és elégedettséget hozott létre (heavy-going satisfaction). Garhammer másik magyarázata azon a pszichológiai megközelítésen alapult, mely szerint az időhiány, pozitív hatásként mozgósítja az egyén tartalékforrásait. Ennek következtében pedig egy olyan társadalomban, ahol az egyént túlságosan is sokféle vonzó lehetőség veszi körül idejének eltöltésére (multiple-choice-society), önkéntelenül is sokféle tevékenységben vesz részt. Ugyanannyi idő alatt minél több tapasztalatot szeretne szerezni, így elégedettséget számára a minél többféle tevékenység és kikapcsolódási forma, a minél többféle élmény megszerzése jelenti. 
A második szakaszhoz tartozó elméletek között kell továbbá említeni Headey és Wearing korai koncepcióját, amelyben a szubjektív jóllét fogalmát szintén kognitív és affektív felbontásban értelmezték, az affektív jóllét oldalát pozitív és negatív összetveőkre bontották (positive affect and negative affect), a negatív érzéseket pedig további kettő dimenzióra: nyugtalanságra és depresszióra (anxiety and depression). A kognitív oldalt hagyományosan az élettel való elégedettséggel (cognitive life staisfaction) definiálták. (Headey-Wearing, 1989:732). Elméleti modelljüket, amelyet dinamikus egyensúlyi modellként neveztek el, a jóllét hosszú távú alakulásának vizsgálatakor, néhány évet átfogó ausztrál háztartáspanel adatokat elemezve dolgozták ki. Az empirikus eredményeik szerint az egyének átlagos szubjektív jóllétszintjét az életkor és a személyiség-jellemzők határozták meg hosszú távon, mely csupán jelentős életesemények (válás, gyermekszületés, stb.) hatására tért el az egyénre jellemző értéktartománytól. Az életeseményekre a kutatók, mint a szubjektív jóllétet kívülről befolyásoló (exogenous) hatótényezőként tekintettek, és a vizsgálatban kedvező és kedvezőtlen típusokra bontották azokat. Az eseményeket összefoglaló listában a kedvező életeseményekhez (például: új barátok szerzése, házasság) a kutatók plusz 1 pontot, míg a kedvezőtlenekhez (például: munkanélkülivé válás) -1 pontot rendeltek, melyeket összegeztek. A kedvező események az extrovert, a kedvezőtlenek a neurotikus személyes jellemzőkkel mutattak szignifikáns kapcsolatot. Az életkor esetében a fiatalabb életkori korcsoportok az előbbi, az idősebb korcsoportok az utóbbi eseménytípussal korreláltak erősen. A dinamikus egyensúlyi modellnek nevezett tézisük szerint a jóléti társadalmakban minden ember rendelkezik egy ,átlagos” életeseménymintázattal és egy „átlagos” egyéni jóllét-szinttel, mely az életkor és az állandó személyiségjellemzők alapján előre jelezhető. Ezt a tézisüket azonban később Headey és mások felülvizsgálták, mely kutatások már a bevezetőben bemutatott harmadik kutatás-fejlődési szakaszhoz sorolhatóak (Headey et al., 1993). Headey és szerzőtársai, dinamikus egynsúlyi elméletüket a német, később pedig a brit háztartáspanel adatokon is tesztelték. E korai koncepció revíziója során bontakozott ki az ún. „set-point” elmélet, melyet a személyes életesemények szerepével kapcsolatosan további empirikus tesztek is igazoltak (Headey, 2006, 2008; Lucas et al., 2003; Lucas et al., 2004), illetve a gazdasági válság kedvezőtlen hatását elemző, későbbiekben bemutatásra kerülő kutatások szintén alátámasztottak (Cummins- 
Wooden, 2014). A teória szerint a fejlett ipari társadalmakban az egyénre jellemző jóllétszint az egyén életútja során egy adott tartományon belül mozog, melyet egyes jelentős életesemények is csupán időszakosan térítenek el ettől az egyénre jellemző értéktől. A vizsgálatokba bevont eltérő életesemények közül azonban a munkanélkülivé válás volt az, amelynek hosszú távú hatása kimutatható volt a jóllét alakulására, akár rövidebb, akár hosszabb távon szorult ki az egyén a munkaerőpiacról, akár egy alkalommal, vagy többször (Headey et al., 2014) ${ }^{5}$.

A hazai jólétkutatások körében a jóllét materiális és immateriális aspektusainak vizsgálatára hosszú távú adatsorok elemzésével kevés kutatás vállalkozott. Az életszínvonallal való elégedettség mértékét és annak időbeli alakulását vizsgálta Keller Tamás (2008) a Magyar Háztartás Panel adatain. A jólét anyagi oldalának és meghatározó tényezőinek alakulását 1992 és 2007 között, objektív és szubjektív indikátorok bevonásával elemezte. Eredményei alapján megállapította, hogy az életszínvonallal való elégedettséget a jövedelem és az iskolai végzettség mellett jelentősen meghatározzák az egyén jövőre irányuló várakozásai. Ez utóbbi szubjektív változó bevonása mintegy 30 százalékkal javította a modell magyarázóerejét. Azonban míg az időben előrehaladva a jövedelem hatása csökkent, addig az aspirációs szint szerepe egyre erősödött az elégedettség meghatározásában. A tanulmányban a szerző megvizsgálta az aspirációs szint szerepét a jövedelem alakulásában, tehát független változóként, azonban az adatok azt mutatták, hogy a jövőre vonatkozó pozitív várakozások minimális mértékben határozzák meg az elért jövedelemszintet. Korábban már Richard E. Easterlin (2001) is megvizsgálta az aspirációk szubjektív jóllétre kifejtett szerepét, és megállapította, hogy amíg az elégedettségre a jövedelem közvetlenül, az anyagi aspirációk fordított módon hatnak. Kutatásában rámutatott arra, hogy az egyes jövedelmi csoportok között hasonló aspirációs szint a jellemző, és az életút elején a nagyobb jövedelem nagyobb boldogsággal jár. Azonban az aspirációs szint a jövedelem növekedésével együtt növekszik, így a jövedelemnövekedés egyéni jóllétre kifejtett pozitív hatását az aspirációs szint emelkedéséből származó negatív hatás (,kielégítetlenség érzet”)

5 Headey és szerzőtársai (2014) említett írása, illetve a korábbi panelvizsgálatok: Lucas és szerzőtársai 2004-es; illetve Headey 2010-es cikke) a 1994-es Clark-Oswald és a 2003-as Clark tanulmányon túlmutatnak a munkanélküliséggel és a szubjektív jólléttel kapcsolatban, amelyhez ugyanezen egyik szerző hasonló témakörben írt tanulmányát jómagam is idéztem korábban (Oswald, 2003). 
lerontja. A szerző szerint az emberek hajlamosak a múltbeli helyzetüket kevésbé pozitívan, a jövőbeli helyzetükkel kapcsolatos várakozásaikat pedig mindig pozitívabban értékelni. Panel adatokat elemezve ezt azzal indokolta, hogy ha valaki jövedelme folyamatosan emelkedik, és annak növekedése mellett a jövőre irányuló aspirációi ha azonos szinten maradnak is, ez akkor is oda fog vezetni, hogy a múltat leértékeli. A megélt boldogság, nyereség (utility) mindig különbözni fog a jövőbelitől, éppen az előre nem látható aspirációs szintváltozásnak köszönhetően, aminek következtében az egyén döntései és választásai mindig téves várakozásokon fognak alapulni, és így a megszerzett nyereség (boldogság) sohasem növekszik olyan mértékben, ahogyan azt az egyén eltervezte (Easterlin, 2001:481). A jövedelemszint változásának szubjektív jóllétre kifejtett hatásához más tényezők is hozzájárulnak, mint például a stressz csökkenése. Gardner és Oswald empirikus vizsgálatában rámutatott, hogy egy bizonyos jövedelemszint felett a jövedelem csökkenése együtt jár a szellemi megterhelés és stressz csökkenésével, ami magasabb boldogságérzetet eredményez. (Gardner-Oswald, 2001). A német háztartáspanel 1992 és 1997-es hullámok összevont adatain a szubjektív jóllét mértékét meghatározó tényezők, köztük az anyagi aspirációk szerepét vizsgáltva Frey és Stutzer megállapította, hogy a háztartás jövedelme és az élettel való elégedettség jóllehet pozitív összefüggést mutat, azonban egy adott jövedelemszint mellett a magasabb aspirációval rendelkezők alacsonyabb elégedettségről számoltak be (Frey-Stutzer, 2003b). Számos kutatásban igazolták azt is, hogy egy bizonyos abszolút jövedelemszint felett a relatív jövedelmi különbségek sokkal inkább befolyásolják az egyéni jóllétet és boldogságot, mint az abszolút különbségek (Graham-Pettinato, 2002).

Ez pedig már átvezet ahhoz az összehasonlítás elmélethez, amely szintén lényeges vonulata volt a szubjektív jóllét területét meghatározó szociológiai kutatásoknak. Kiindulva a mertoni társas összehasonlítás elméletéből (Merton, 2002), az egyén számos vonatkoztatási csoporthoz viszonyítva értékeli saját helyzetét, ahogyan egyéni jóllétét is. Michalos 1985-ben írt tanulmányában különböző szempontok alapján az egyén által elvégzett összehasonlítások együtteséből vezeti le azt a kognitív modellt (multiple discrepancies theory), amellyel az élet minőségét magyarázni próbálja. Az egyén és különböző csoportok közötti, illetve saját helyzete és várakozása közötti távolságok összegzéseként jön létre egy az egyén által érzékelt 
jelenbeli, illetve kívánatosnak tartott helyzet (perceived self now/wants), ami vagy elégedettség érzetet ad számára, vagy elégedetlenséghez vezet. A végeredményt (net satisfaction) természetesen befolyásolják szocio-demográfiai változók, az önbecsülés mértéke és a társas-támogató kapcsolatok léte vagy hiánya, mint az összehasonlítások háttértényezői, de egyéb tényezők is. Az összehasonlítás alapjául Michalos segítségül hív néhány szociálpszichológiai elméletet, úgymint a referenciacsoport elmélet (self/other comparison), a méltányosság elméletet (self/deserved comparison), és az aspirációs elméletet. Mivel a modell csupán az elégedettséget veszi figyelembe, tehát a szubjektív jóllét kognitív oldalát, és nem vonja be az affektív oldalt, ezért alapvetően nem alkalmas arra, hogy egy átfogó jóllétről adjon képet a szubjektum szintjén (Michalos, 1985, idézi Schulz, 1995:155-156).

A társas összehasonlítás és a relatív jövedelmi helyzet elméleteket vette alapul Hajdú Gábor és Hajdú Tamás (2011) az élettel való elégedettség mértékének vizsgálata során. Kiindulópontjuk szerint az egyéni jólét mértéke összefügg az egyén abszolút jövedelmi helyzetével, ugyanakkor a szubjektív jóllét mértékét meghatározza az is, hogy az emberek kikhez hasonlítják jövedelmi helyzetüket (relatív jövedelmi helyzet). Az összehasonlítás folyamatában, a referenciacsoport jövedelmi helyzetének javulásáról érkező információ az egyéni jóllét mértékére kettős hatást fejt ki. Míg a hasonló társadalmi helyzetű csoportok körében az elégedettség mértékét javítja ez az információ, addig az egyén és a vonatkoztatási csoport értelmében egymástól távol eső státuszcsoportok esetében ez az „információhatás” már nem játszik meghatározó szerepet, az összehasonlítást elsősorban csak a státusz befolyásolja (státuszhatás). A társas összehasonlítás mertoni elmélete szerint az összehasonlítás folyamatában a magunkról, saját helyzetünkről alkotott értékelést az a tény határozza meg, hogy kihez, vagy kikhez hasonlítjuk magunkat, életkörülményeinket, elért státuszunkat, anyagi és vagyoni helyzetünket, mely értékelés alapvetően az általunk megválasztott referenciacsoport helyzetétől függ (Merton, 2002). Sági Matild a mertoni elméletre hivatkozva azonban úgy látta, hogy a rendszerváltozást követően a magyar lakosság kedvezőbb anyagi helyzetü csoportja - jövedelmi és vagyoni körülményei javulásával, egy bizonyos státusz és életszínvonal elérése után - referenciacsoportot váltott, és nem a közép-kelet- hanem a nyugat-európai lakosok anyagi-jövedelmi helyzetéhez 
hasonlította önmagát. Ebből következően a legjobb jövedelmi körülmények között élők lényegesen nagyobb jövedelemfeszültséget, s ez által alacsonyabb elégedettségés jóllétérzetet éltek meg, mint azok, akik az országos átlaghoz, illetve szükebb környezetükhöz viszonyították saját helyzetüket (Sági, 2000, 2002).

A szubjektív életminőség értékelésének megértéséhez azonban a vonatkoztatási csoport elméletét túlzottan leegyszerüsítő modellnek vélte későbbi kutatásai során Diener és Fujita (1997). Szerintük az egyéni jóllét, illetve a személyes élethelyzet értékelésekor az elérni kívánt célok és azok megvalósulása játszik döntő szerepet. Ez a teória „értékelés elméletként” vált ismertté. A koncepció értelmében a szubjektív jóllétről alkotott becslést alapvetően az egyén ítélőképességének állandó elvei, az ún. irányadó minták (standardok) határozzák meg, melyeket alapvetően a kultúra és a társadalmi értékrendszerek alakítanak ki. A szerzők álláspontja szerint a társas összehasonlítás feltehetőleg akkor fejti ki erősebb hatását az élet globális értékelésekor, ha az éppen elérni kívánt célokat befolyásolja. A megélt élet minőségével kapcsolatos értékelést természetesen helyzeti szituációk is befolyásolhatják, de alapvetően az egyéni standardok (mint például a célok) azok, amelyek meghatározzák az egyén értékelését a saját jóllétéről. Diener és BiswasDiener (2000) szezőtársak kapcsolódó kutatásai szerint, minden embert más tesz boldoggá, hiszen mindenki más célokat tűz ki maga elé. Azonban, ha az egyén eléri céljait és mindez egységben van a személyes értékeivel, várhatóan boldogabb és elégedettebb lesz, mint azok, akik például céljaik elérésének folyamatában konfliktusba kerülnek saját értékrendjükkel. Azonban ezeknek az egyéni standardoknak a hatása nem közvetlen módon érvényesül a boldogság alakulásában, ahogyan azt a 20 évet átfogó panel-vizsgálat kimutatta, hanem közvetett módon, az egyén személyes jellemzőivel együttesen (Headey, 2008).

Nem véletlenül vizsgálta számos kutatás a jellegzetes viselkedési minták és az egyéni jóllét összefüggését. Az attitűdök, melyek személyiségjellemzők által meghatározottak, összefüggenek az egyének eltérő életminőségével (Wrosch és Scheier, 2003). A pesszimistákkal szemben az optimista beállítottságú emberek például sokkal gyakrabban léptek fel aktív problémamegoldó szerepben és használnak érzelmi adaptációs technikát akkor, amikor a fontos életcéljaikban nem tudtak előrelépést tenni. Ennek következtében az optimisták jobb életminőséget értek 
el. Magasabb egyéni jóllétről számoltak be azok az emberek is, akik képesek voltak arra, hogy az elérhetetlen célokhoz való ragaszkodásról lemondjanak, és más, reálisabb célokat válasszanak maguknak. Mindezen tényezők és összefüggések a recesszió időszakát vizsgálva kiemelt jelentőséget kapnak, hiszen a válság éveiben a lakosság a mindennapi, megszokott életmódján volt kénytelen változtatni, és egy racionálisabb életvezetést bevezetni, ami az egészségének fenntartására fordított kiadásoknak, vagy a szabadidejére fordított anyagiaknak a csökkentését is jelenthette (European Commission, 2014). A válság jóllétre kifejtett hatását vizsgáló irodalom szerint, a belső erőforrásként is definiált optimizmus általában egy pozitív adaptációs technikának tekinthető a nehézségek leküzdésében. Azonban az alacsony szubjektív jólléttel jellemezhető csoportok esetében a túlzott optimizmus az egyén által kezelhetetlen helyzetre adott érzelmi reakciónak és egyfajta helytelen alkalmazkodásnak is tekinthető (Cummins et al., 2014). Az optimista és pesszimista személyes jellemzőn túl olyan személyiségvonások is a jóllét vizsgálatok középpontjába kerültek, mint a temperamentum, vagy a személy exrtovert vagy introvert beállítottsága. Míg a veleszületett temperamentum erős összefüggést mutatott a szubjektív jólléttel, az extrovert és introvert beállítottságok egyéni jóllétre, elsősorban annak affektív oldalára kifejtett hosszú távú hatását további vizsgálatok is alátámasztották (Headey\&Wearing, 1989; Headey et al., 1993; Diener et al., 1999).

A szubjektív jóllét és életminőség körül kialakult tudományos viták az „erőforrások vs képességek” problematikája mentén is körvonalazódtak. Az erőforrás elmélet képviselői - elsősorban közgazdászok, és a fentiekben bemutatott eriksoni elmélet mögé felsorakozó tudósok - értelmezésében az egyéni jóllét mértékét a rendelkezésére álló javak határozzák meg. Azonban Amartya Sen (1993) „capabilities approach” koncepciója a képességek mellett tette le a voksot. Szerinte nem az a meghatározó az egyéni jóllét mérésekor, hogy ki mennyi, illetve milyen jellegü erőforrásokkal rendelkezik, hanem az, hogy ezeket a rendelkezésére álló javakat hogyan tudja felhasználni. Ez pedig nemcsak az egyén személyes képességeitől függ - mind a fizikai, mind a mentális képességeket értve ez alatt -, de a társadalmi és fizikai környezettől is.

Az ezredfordulón Ruut Veenhoven (2000) egy integrált modellben definiálta az életminőséget meghatározó négy fő terület, mely megközelítés magában foglalta az 
egyéni képességeket és a környezeti tényezőket is. A négyes mátrixot az egyéntől függő és független életfeltételek, és a külső és belső szempontok szerinti értékelések feszíti ki. A mátrix első két területét a jó életkörülményeket biztosító, élhető természeti környezet megléte biztosítja egyrészről, másrészről az egyén képességei és készségei, melyek a jólét megteremtéséhez nélkülözhetetlenek. Míg a harmadik összetevő, az életfeltételektől függően elért életkörülmények külső értékelési szempontok szerinti aspektusa, hogy az egyén mennyire érzi hasznosnak az életét, akár azért, mert gyermeket nevel, vagy azért mert jó állampolgárnak érzi magát. A negyedik pedig, a belső szürő alapján az egyén saját szubjektív érzékelése, hogy mennyire érzi életét boldognak, mennyire elégedett az életével, a munkájával és az egyéb életterületekkel.

Az erőforrás elmélethez kapcsolódóan, azonban a környezeti tényezők szerepét is feigyelembe véve végzett kutatásokat a szubjektív jóllét terültén Lengyel György és Janky Béla (2003). Tanulmányukban az anyagi, a kulturális és a társadalmi erőforrások meghatározó szerepét vizsgálták az egyéni jóllét alakulásában, magyar adatokon, önálló modellben megvizsgálva az élettel való elégedettséget és a boldogságot meghatározó társadalmi-demográfiai tényezők szerepét. A kutatás eredményei szerint magasabb szubjektív jóllét a tőkepiacon jelenlévőket és a vállalkozókat jellemezte elsősorban. Az átlagtól nagyobb arányban fordultak elő elégedett és boldog válaszadók azok között, akik leginkább megbíztak az emberekben, a demokratikus intézményekben, illetve akik magas iskolai végzettséggel rendelkeztek. Elégedetlenebbek és boldogtalanabbak voltak e tekintetben azok, akik a baráti kapcsolatok hiányáról számoltak be, és gazdasági, politikai, környezeti vagy közbiztonsági okokból biztonsághiányt szenvedtek el. Az együttes hatások elemzése alapján a szerzők megállapították, hogy a materiális tényezők mindkettő szubjektív értékelést jelentősen befolyásolták, azonban a jóllét érzelmi aspektusának alakulására elsősorban a közvetlen kapcsolatok fejtettek ki jelentős hatást. A kontextuális változók közül a település jellemzői (anyagi-, infrastrukturális viszonyok, a közbiztonság, és a környezet segítőkészsége) kevésbé az elégedettséget, sokkal inkább a boldogságérzetet magyarázták kutatási eredményeik alapján.

A társadalmi tőke a legtöbb szociológiai vizsgálatban, tágabb értelemben az 
egyén szervezetekhez füződő kapcsolatait, tagságát, szűkebb értelemben a közvetlen baráti, családi kapcsolatait fogja át. A családi és baráti kapcsolatok egyéni életminőséget meghatározó szerepét hangsúlyozta Utasi Ágnes (2008) tanulmánya. Kutatásában, melyben a 2000-es évek magyar adatait elemezte, megállapította, hogy a társadalmi tőke jelentősen lecsökkent hazánkban az elmúlt évtizedekben. Így az egyéni jóllét alakulását elsősorban a közvetlen családi, baráti kapcsolatok befolyásolták. Tehát a lakosság szubjektív jóllétét ezek a közvetlen támogató kapcsolatok tudták javítani, illetve fenntartani azok instrumentáélis funkciójukból adódóan. Jóllehet kedvezőtlen mellékhatásként ezzel együtt megjelent a „,családba zárkózás” jelensége Magyarországon, ami a kutató szerint éppen abból adódott, hogy az emberek a mindennapokban egyre nehezebben bírkóztak meg a változó életkörülményeikkel a rendelkezésükre álló szűkös erőforrásaikból.

A társadalmi tőke szerepének vizsgálata, láthattuk, hogy lényeges kutatási terültete a szubjektív jóllétnek, amelyet a jóllét kutatások harmadik szakaszához kapcsolódóan említünk meg. Robert Lane (1996) amerikai és nyugat-európai adatokat elemezve a társadalmi tőke csökkenése kapcsán tulajdonképpen arra kereste a választ, hogy vajon miért találunk ma annyi boldogtalan embert a fejlett piacgazdasággal rendelkező országokban és jóléti társadalmakban. Kérdést a társadalmi jólét oldaláról megközelítve fogalmazza meg, nevezetesen, hogyan kapcsolódik össze az emberek boldogsága a demokráciával és a piacgazdasággal, illetve melyek a végső céljai egy jóléti társadalomnak. Továbbá ha a jólét lényege valóban az, hogy a legnagyobb boldogságot érjük el a legtöbb ember számára, akkor kérdés, hogy a fejlett országok intézményei, mint a demokratikus politikai rendszerek és a piacgazdaság mennyire szolgálják ezt a célt? Lane megközelítése alapvetően közgazdaságtani elveken alapul, hiszen a boldogságot az egyik lehetséges elérendő jószágnak tartva azt maga is a javak körébe sorolja. Szerinte a boldogság olyan ,jószág”, amelyet az egyén más, ún. végső javak megszerzésével és fenntartásával érhet el, melyek maguk jelentik a boldogság forrását. Ezek a javak a fejlett jóléti társadalmakban a következők: (1) a szubjektív jóllét, (2) az emberi fejlődés, és (3) az igazságosság. Tézise szerint azokban a társadalmakban, ahol az anyagi javak szükös forrásként vannak jelen és a társas kapcsolatok sűrüsége nagy, maga a pénz nagyobb mértékben járul hozzá a szubjektív jóllét emelkedéséhez. 
Azokban az országokban viszont, ahol az anyagi javakkal való ellátottság bőséges és a kapcsolatok szegényesek, ott a kapcsolatok lesznek a szubjektív jóllét mértékét növelő források. A szerző szerint a piac nem tudja pótolni azokat a forrásokat, amelyekre szüksége van az embereknek ahhoz, hogy boldogan éljenek. Lane a társadalmi tőkét (a barátságot és a jó családi életet) tartja a szubjektív jóllét két alapvető forrásának. Véleménye szerint a piaci demokráciákban a piac csupán hasznot maximalizál, és a piacon a társas szükségletek, mint „,piaci externáliák” jelennek meg, azonban a piaci szolgáltatások még a barátság gyenge helyettesítőinek sem tekinthetők. Lane, hasonlóan Putnam korábbi megállapításaihoz, a társastársadalmi kapcsolatok gyengüléséröl, a társadalmi tőke hanyatlásáról beszél. Ezen tézise összecseng számos kutatás azon eredményével, mely szerint a családi szolidaritás csökkenése és a közösségek integratív erejének eróziója vezetett el ahhoz, hogy a fejlett társadalmakban ma nagyobb arányban számolnak be az emberek boldogtalanságról, és az egymásba és a társadalmi intézményekbe vetett bizalom hiányáról, mint ezek ellenkezőjéről (Lane, 1996, 2000; Putnam, 1995, idézi: Lengyel-Szántó, 1998).

Kutatók más csoportja ezzel szemben úgy látja, hogy az alkotmányos demokráciákban, jóléti társadalmakban élő emberek sokkal inkább boldogabbak, mint bármely más társadalmi berendezkedésű országok lakosai. Állításukat azzal indokolták, hogy a demokratikus államok politikai pártjai a választások sikereiért kénytelenek figyelembe venni szavazóik igényeit és bizonyos jóléti intézkedéseket bevezetni. A választások, a demokratikus részvétel pedig önmagában javítják az állampolgárok boldogságát, szemben azokkal az országokkal, ahol akár az országos akár a helyi politikában és döntéshozásban való részvételre nincs lehetőség. A fejlett országok közül Svájc adatait elemezve Frey és Stutzer (1999) azt is megállapították, hogy a demokratikus intézmények müködésében való egyéni részvétel széleskörü lehetősége (pl. önkormányzatiság megvalósítása, helyi népszavazások kezdeményezése, vagy a decentralizált kormányzati struktúra) pozitív hatással vannak az egyének szubjektív jóllétére. Ezzel hasonló eredményre jutott Inman és Oberholzer-Gee (2003) kutatásukban, amikor a demokratikus országok adatait elemezve szintén az intézményi részvétel és a szubjektív jóllét kapcsolatát vizsgálták. A kutatók, a demokratikus társadalmi intézmények néhány formája közül az 
iskolákat támogató csoportokban és egyéb közösségi problémák (mint például közbiztonság) megoldására létrejött civil szervezetekben való részvétel és a szubjektív jóllét mutatói között pozitív összefüggést találtak. Ugyanakkor negatív irányú volt a kapcsolatot a politikai részvételt biztosító szavazással összefüggésben (az országgyülési választások esetében), ami azt mutatta, hogy a magukat boldognak valló emberek elmentek ugyan szavazni, de a szavazás nem állt oksági összefüggésben a boldogsággal.

A szubjektív jóllét és életminőség kutatási területét a közgazdaságtani megközelítések jelentős mértékben megtermékenyítették, melyek a boldogságot a javak körébe sorolták. A megközelítés alapján a boldogság maga is egy megszerzendő ,jószág”, amely realizációja ugyan úgy mérhető, mint bármely más javakkal való ellátottság. Azt, hogy ebben a megközelítésben miért is érdemes a közgazdaságtani koncepciókra figyelmet fordítani, néhány teória és empirikus eredményt citálva mutatjuk be a „,happiness economics” területéről. Frey és Stutzer (2001) szerint három tényező miatt szükséges a boldogság kutatások eredményeit a közgazdászoknak és a döntéshozóknak figyelembe venni. Egyrészt azért, mert hasznos információt nyújtanak a gazdaságpolitikai döntéshozók számára, amire példaként a munkanélküliséget említik a szerzők. Szerintük nem elegendő csupán azt mondani, hogy a munkanélküliség bizonyos mértékü inflációcsökkentéssel ellensúlyozható. Szükséges annak a ténynek is a figyelembevétele, hogy a munkanélküliség jelentős nem financiális költségeket is produkál, melyek éppen az individulás jólléttel hozhatók kapcsolatba. Másrészt a boldogság kutatások visszajelzést adnak a társadalmi intézmények müködéséről, így például a kormányzati tevékenység minőségéről is. Példaként említik, hogy az elszámoltathatóság, a korrupció kontrollja és a kormányzás stabilitása pozitívan hat az állampolgárok jóllétére. Harmadsorban pedig magának a szubjektív jóllétnek az összetevőit, a kialakulását érthetjük meg jobban, ha közgazdaságtani szempontokat is figyelembe veszünk. A szerzők megállapítják, hogy jóllehet a boldogság nem azonos a hasznosság tradicionális közgazdaságtani fogalmával, de elfogadják Veenhoven meghatározását, mely szerint az egyén a lehető legmegbízhatóbb értékelő forrása a saját boldogságának és a saját életével való elégedettségnek, hiszen a múltbeli helyzetét, a másokhoz viszonyított körülményeit és a jövőre irányuló 
aspirációit és céljait együttesen figyelembe véve ad értékelést a saját egyéni jóllétéről. Ezért a közgazdászok a szubjektív jóllét mérését elfogadták a hasznosság (utility) helyettesítő empirikus mérőeszközeként, ahogyan ez megjelent a hazai szakirodalomban is (Lelkes, 2003). Frey és Stutzer megvizsgálták a jövedelemnek, a munkanélküliségnek, az inflációs rátának és a társadalmi intézményeknek (mint gazdasági, politikai és személyes szabadságjogok gyakorlásának) a boldogságra kifejtett hatását. A jövedelem növekedése egy bizonyos jövedelem szint fölött nem növelte ugyan olyan mértékben a boldogság érzetet, mint amikor az, az alacsonyabb jövedelmek növekedése esetén tapasztalható volt. Ugyanakkor azonos jövedelmi viszonyok között az egyén aspirációi nagymértékben differenciálták az elégedettségi fokokat. Ezen utóbbi összefüggésre később rámutattak hazai panelelemzések az életszínvonallal való elégedettség vizsgálatakor (Keller, 2008), de külföldi empirikus vizsgálatok is, melyek szerint az aspirációs szint hatását a társadalmak berendezkedése szintén befolyásolja. A volt szocialista országokban, de Peruban, vagy Oroszországban a kilencvenes évekre lezajlott általános gazdasági javulás ellenére a szubjektív jóllét alacsony maradt, föként az irreális aspirációk miatt (Ryan et al., 1999; Frey-Stutzer, 2001). Frey és Stutzer a további lehetséges kutatási területek között javasolják a különböző viselkedési formák és a boldogság kapcsolatának vizsgálatát. Továbbá javasolták a fejlettebb módszertani eljárások alkalmazását is, mint például a paneladatok elemzését, illetve a kohorszelemzés technikájának alkalmazását, amelyektől szerintük mélyrehatóbb eredmények várhatóak.

A nemzetközi összehasonlító kutatások területén tett további lépések azok köré a kérdések köré csoportosultak, hogy tulajdonképpen az egyéni jóllét meghatározásakor mikor kerül előtérbe a kulturális háttér, és hogy ez a jóllét mely aspektusait befolyásolja, és mely komponensei azok, amelyek eltérő kultúrákban is ugyan úgy meghatározó szerepet játszanak (Diener-Tov, 2004). E téren számos nemzetközi összehasonlító vizsgálat indult el az elmúlt évtizedekben, melyekben hazánk is részt vett. Ilyen volt a World Value Survey (WVS), mely politikai, vallási, gazdasági és más társadalmi normákat és értékeket vizsgált a világ hat kontinensének több, mint hatvan országában. A kutatás érintette a szubjektív jóllét (élettel való elégedettség, boldogság) kérdéskörét is. Az értékek vizsgálatára irányuló hasonló 
kezdeményezés volt a European Value Survey (EVS), mely először 1999-2000-ben készült adatfelvétele alapján az európai kulturális különbségeket vizsgálta meg, illetve elemezte azok hatását az európai országok gazdasági növekedésére, a vállalkozói attitűdökre, a civil társadalmi részvétel iránti elkötelezettség és a különböző kapcsolattípusoknak a gazdasági növekedésre kifejtett hatására, illetve a vallási irányzatok - pluralizmus - európai identitás kapcsolatára vonatkozóan (Inglehart et al., 1998; Hagenaars et al., 2003).

Az életminőség és a kultúrák és értékrendszerek összefüggéseinek vizsgálódásai első megközelítésben az eltérő nemzetek és kultúrák egyszerü összehasonlítását eredményezték a boldogság és elégedettség dimenziói mentén. Magyarországon a Magyar Tudományos Akadémia értékszociológiai műhelyében már az 1970-es években megkezdődtek a lakosság életmódjának és értékrendszerének vizsgálatai. A mühely munkáját Hankiss Elemér és kutatótársainak vizsgálatai fémjelzik, akik a hetvenes évek második felétől vizsgálták a magyar lakosság értékrendszeri jellemzőit és bekapcsolódtak nemzetközi összehasonlító kutatásokba (Hankiss-Manchin, 1976; Hankiss, 1980). Hankiss és munkatársai értékkutatásokkal kapcsolatos eredményekről részletes összefoglaló olvasható Szabó (2003) és Keller (2010) munkáiban, melyek itt nem részletezek. A mühely munkájába a '90-es években kapcsolódott be Varga Károly (2002), aki az életminőség és az értékek, értékrendszerek kapcsolatát vizsgálta. Alaphipotézise szerint az egyén értékrendszere közvetett módon fejti ki hatását az életminőségre. Empirikusan igazolja, hogy mind a kognitív elégedettséget, mind az affektív boldogságérzetet tartalmilag más és más társadalomstatisztikai mutatók befolyásolják. Míg az előbbit a vállalkozói attitűd, a család egy főre jutó jövedelemszintje (az anyagi sikeresség), és a derüs életfelfogás valószínüsíti elsősorban, addig az utóbbit az iskolázottság, a falusi életmód és a szolidáris életelv magyarázza erőteljesen.

A mikroszintü elemzések mellet lényegesnek tartjuk megemlíteni Richard Layard (2007) boldogságról írt műve alapján a makrovizsgálatok eredményeit is. Ezek szerint a World Value Survey adatai szerint, alapvetően hat tényező volt az, amelyek segítségével az országok átlagos boldogságszintjei közötti különbségeket magyarázó modellek a szubjektív jóllét varianciájának 80\%-át megmagyarázták. 
Ezek voltak: a válások aránya, a munkanélküliségi ráta, a bizalom szintje, a civil szervezetekben való tagság, a kormányzat minősége, és a hívők aránya.

Jelentős vonulata a szubjektív jóllét kutatási területének az egészséghez kapcsolódó elméleti koncepciók és empirikus vizsgálatok (Patrick, 2006). Számos empirikus kutatás állapította meg, hogy a szubjektív jóllét mértékét alapvetően meghatározza az egyén egészségi állapota, illetve az, ahogyan az individuum érzékeli saját egészségi állapotát. Kopp Mária és Skrabski Árpád (2009) vizsgálta nemzetközi összehasonlító követéses vizsgálatban, 2002-ben és 2006-ban az egyének szubjektív egészségi állapotának alakulását. Kutatásukban a szubjektív életminőséget egyrészt a szubjektív egészségi állapottal definiálták, melyet ötfokú skálán mértek. A skála felső kettő, „kiváló” és ,jó” egészségi állapotot mérő kategóriájába 2002-ben a magyar lakosság kevesebb, mint 50\%-a sorolta önmagát, szemben például a lengyelek 55, az osztrákok 77 és az írek 84\%-os arányával. A 2006-ra hasonlóan kedvezőtlen képet mutató hazai lakossági szubjektív egészségi állapotok mellett, a demográfiai csoportokat elemezve a szerzők azt állapították meg, hogy a gyermekeseknek általában rosszabb volt a szubjektív egészségi állapottal mért életminősége az egyedülállókkal szemben, akár a férfiakat, akár a nőket hasonlították össze. Amikor a kutatók a globális boldogságérzettel mérték a szubjektív életminőséget, nem találtak szignifikáns különbséget a 45 évnél fiatalabbak csoportjában a gyermekes vagy gyermektelen fiatal felnőttek között. A 45-64 évesek korcsoportjában jóval rosszabb önértékelést mutattak mind a nők, mind a férfiak, azonban a romló életminőség a 64 évestől idősebbek életkori korcsoportjára volt a legjellemzőbb. Itt viszont a nemek közötti különbségek is szignifikánsak voltak, a nők körében mért eredmények az átlagostól jóval rosszabb értékeket mutattak.

A szubjektív jóllét és az érzelmi egyensúly közötti kapcsolatot vizsgálva, Schimmack és szerzőtársai (2001) az USA, Németország, mint individualista társadalmak, és Japán, Mexikó és Ghana, mint kollektivista társadalmak adatainak összehasonlító elemzése során az eredmények pozitív kapcsolatot mértek. Ez a kapcsolat erősebb volt az individualista, mint a kollektivista társadalmakban. A kutatók a vizsgálat során olyan személyes jellemzőket is bevontak az elemzésekbe, mint az extrovert és a neurotikus jellemvonások. A személyes attribútumok 
közvetetten, az érzelmi egyensúly változóján, mint mediátor változón keresztül fejtették ki a szubjektív életminőségre gyakorolt hatásukat.

\subsection{A szubjektív jóllét alakulása konjunktúrák és gazdasági válságok idején}

A jóléti társadalmak elmúlt évtizedek alatt elért fejlődésének és az országok átlagos boldogságának kapcsolatát vizsgálta meg Easterlin (1974). Tézise (az Easterlin-paradoxon) szerint a gazdasági fejlödés és a jövedelmek emelkedése nem jár együtt a lakosság életminőségének és az egyének boldogságának emelkedésével. Easterlin 1947 és 1970 között megvizsgálta több eltérő kultúrájú ország makrogazdasági mutatóinak és a boldogságnak az összefüggését, illetve az egyes országokon belüli változásokat is elemezte. A vizsgált időszakban a fejlett ipari országok, mint például Japán és az USA jelentős gazdasági prosperitást mutattak, ugyanakkor a lakosság boldogságszintje ezzel összhangban nem emelkedett hasonló módon. Az országon belüli változásokat elemezve ugyanazon összefüggésre mutatott rá a szerző, az Egyesült Államok esetében, amíg 1947-ben a megkérdezett amerikaiak 47\%-a válaszolta azt, hogy nagyon boldog, 1970-ben 43\%-uk. Az amerikai lakosság eltérő jövedelmi csoportjainak szubjektív jólléte is alig mutatott változást a három évtized alatt, amelyet más kutatások is alátámasztottak (Easterlin, 1974:109; Diener et al., 1999:288).Hasonló tényekről számolt be Madden (2011), a kelta kistigrisnek nevezett Írországban 1994 és 2001 között jelentős gazdasági konjunktúra zajlott le. Azonban ezt a prosperitást nem követték a szubjektív jóllét és az egyes életterületekkel való elégedettségi mutatók változásai az ír lakosság körében.

Az Easterlin-paradoxonnal szemben foglalt állást Veenhoven és Hagerty (2006). Empirikus kutatásaik alátámasztották, hogy az országok gazdasági fejlődése együtt jár a szubjektív jóllét emelkedésével. Az 1946 és 2014 közötti időszakot áttekintve 43 ország adatait elemezve a szerzők megállapították, hogy a gazdasági fejlődés igenis hozzájárul az adott ország jóllétéhez, a lakosság életminőségének javulásához. Az adatok, a gazdasági fejlődéssel, a növekvő 
GDP adatokkal párhuzamosan enyhén javuló jóllétről, valamelyest emelkedő boldogságérzetről tanúskodtak (például „Brazília +1.46 , India +1.10 , Nigéria +1.05”) a kevésbé fejlett országokban. Szerényebb javulást pedig a fejlett ipari társadalmak (például „Japán +0.53 ”, de az USA és az EU fejlett országai) is produkáltak az elmúlt évtizedekben (Veenhoven-Hagerty, 2006:11). Az összefüggéseket későbbi tanulmányában Veenhoven (2014) ismét alátámasztotta.

Ezt követően a kelet-európai térség posztkommunista országait vizsgálva Easterlin ismét saját tézisét megerősítő eredményekről számolt be. Az átmenet éveit jellemző elégedettségi adatokat vetette össze az ezredfordulót követő 2005 ös év adataival, és azt állapította meg, hogy a kelet-európai társadalmak élettel való elégedettsége valamelyest javult, azonban más életterületekkel, mint az egészséggel, a környezettel és a családdal való elégedettség azonban csökkent a vizsgált időszakban. Ugyanakkor az élettel való elégedettség egy tágabb időperspektívában mégsem mutatott javulást, Magyarországon például 1982-ben az élettel való elégedettség átlaga 6.93, 1990-ben 6.03, míg 2005-ben 6.30 volt (Easterlin, 2009).

Magyarországon a rendszerváltozás előtti társadalmi állapotokról többek között Andorka (1992) kutatási eredményei számolnak be. E szerint a magyar társadalmat jellemző anyagi életkörülmények a század második felében fokozatosan javultak, azonban az 1970-es évek második felétől e tendencia lassulni kezdett. Sőt, bizonyos életterületeken a javulás teljesen leállt, amit nagy „munka-erőfeszítések” árán tudott ellensúlyozni a magyar lakosság. Az emberi kapcsolatok terén a családirokoni-baráti kapcsolatok intenzívek maradtak és lényeges támogatást nyújtottak az egyének számára, míg az ismeretségi körön kívülállókkal szemben a nagyfokú bizalmatlanság volt a jellemző, melyet Andorka szerint az magyarázhatott, hogy a társadalomban nem terjedtek el a kooperációnak és a reciprocitásnak a mintái (Andorka, 1992:321). A rendszerváltozást követően Andorka az objektív indikátorok mellett rendszeresen vizsgálta az elégedettség és az egyéni boldogság alakulását is, mint a jóllét összetevőit. Véleménye szerint Magyarországon a '90-es évektől kezdődően súlyosabb problémák halmozódtak fel az életminőség és az emberi és társadalmi kapcsolatok területén, mint az objektív mutatókkal mért életkörülmények tekintetében. A kilencvenes évek közepére nőtt a jövedelemegyenlötlenség a 
társadalomban, és elsősorban a deprivált csoportok tagjai között mértek a kutatások magasabb fokú anómiát és elidegenedést, és mutatták ki a depressziós tünetek nagyobb gyakoriságát (Andorka, 1996).

A kilencvenes éveket elemző további mikro-szintü vizsgálatok empirikus eredményei szerint Magyarországon a rendszerváltozást követően az objektív életkörülmények javulását figyelhetjük meg. Az élet egyes részterületeivel (life domains) kapcsolatosan a megkérdezettek évről évre, jóllehet enyhén növekvő, de mégis kedvezőbb értékelést adtak, ugyanakkor a szubjektív jóllét szintje nem emelkedett, sőt az affektív oldal, a boldogság átlagos értékei csökkenést mutattak. Legkiegyensúlyozottabb képet e tekintetben a vallásos emberek mutattak, illetve azok a vállalkozók, akiknél a társadalmi-gazdasági változások leginkább pozitív mérleget eredményeztek. A rendszerváltozást követően a magyarok szabadságérzete megnőtt, azonban csökkent az emberekbe és a társadalmi intézményekbe vetett bizalom mértéke. A lakosság biztonságérzete szintén csökkenést mutatott, nőtt a pesszimista válaszok aránya, erősödött a bizonytalanságérzet és általában romlott a lakosság lelki állapota (Lengyel-Tóth, 1998; Elekes-Paksi, 2000; Kopp-Skrabski, 2000). Az átmeneti időszakot követő éveket vizsgálta nemzetközi adatokon, köztük Magyarország adatait is elemezve, Lengyel és Hegedűs (2004). Tanulmányukban három makrotényező szerepét vették górcső alá: az országok gazdasági fejlettségét, a szektoriális foglalkoztatotti arányt, és a vallásosság mértékét. A részeredményektől itt eltekintve, az elemzés általában megállapította, hogy az egyes országok szubjektív jóllétének mértékét az egy foglalkoztatottra jutó GDP és a munkanélküliségi ráta mértéke jelentősen meghatározza (előbbi pozitív, utóbbi erős negatív kapcsolatban állt a függő változóval). Továbbá a jóllét alakulására jelentős hatással volt a szolgáltatási (és nem az ipari) szektorban dolgozók aránya, mely szintén pozitív összefüggést mutatott, ahogyan a vallásosság esetében a templomba járók arányának mutatója is. A gazdasági recessziónak a szubjektív jóllét mértékére kifejtett negatív hatását szintén minden országra vonatkozóan sikerült a szerzőknek a kutatásukban kimutatniuk, mely összefüggés a posztszocialista országok esetében volt a legerősebb, az államszocialista múlt kontrolltényezőjének bevonása mellett is. A kutatási eredmények magyarázatánál, a gazdasági recesszió negatív hatása mellett, a szocialista rendszerből megörökölt társadalmi normák máig ható szerepével hozták 
összefüggésbe az eredményeket a szerzők. Az ingleharti tézisből kiindulva a kutatók úgy vélték, hogy a megörökölt társadalmi normák, melyek a sikeresség kedvezötlen társadalmi megítélését jelentették, nem adtak teret az elégedettség és boldogság érzéseinek kifejezésre juttatásához, sokkal inkább a panaszkodáshoz. A megörökölt normák mellett a keleti-európai régió országaiban, így hazánkban is, a kulturális tényezőkkel összekapcsolódva lényeges szerepet játszottak a rendszerváltozást követően elszabadult és a szükséges feltételek híján realizálatlanul maradt aspirációk. Ahogyan az átalakuló intézményi és társadalmi környezet által megkívánt adaptációhoz szükséges kompetenciák hiánya miatti frusztrációk is kifejthették hatásukat a lakosság jóllétének alakulásában.

A szubjektív jóllét témakörében, a fejlett országok paneladatain kidolgozott, a dinamikus egyensúlyi modellből kiindulva „set-point” elméletként kikristályosodó teória az elmúlt 30 év távlatában, újabb empirikus tények és elméleti megközelítések hiányában kimerülni látszott (Headey, 2006, 2008, 2010; Headey et al., 2014). A gazdasági válságot követően azonban ismét a kutatások középpontjába került, az egyensúlyra törekvő homeosztatikus rendszerek sajátosságaira épülő korábbi cumminsi elmélettel összefüggésben (Cummins et al., 2014; Cummins-Wooden, 2014). Cummins és szerzőtársainak kutatásai a 2001-2011 között felvett, 10 hullámot átfogó ausztrál háztartáspanel adatokon végzett elemzések eredményeire épültek. A vizsgálat a szubjektív jóllét meghatározó tényezői közül egy olyan egyéni képességet állít a magyarázat fókuszába, mely az individuumnak a nehézségek leküzdésében, a negatív folyamatokkal szembeni ellenálló képességében ragadható meg. Ezt a mikro-sajátosságot, mint egyéni jellemzőt a rugalmasság (resilience) fogalommal definiálták, és az élettel való elégedettséggel (mint globális szubjektív jóllét mutatóval) mérték. A kutatási koncepcióban három tényező határozta meg a szubjektív jóllét mértékét, melynek hosszú távú alakulását a válság, mint külső negatív változás hatásának tükrében vizsgálták meg. Egyrészt a jóllétnek a negatív külső esemény bekövetkezésének időpontjában mért kiindulóértéke, másrészt az egyének alkalmazkodó képessége (rugalmasság foka), harmadrészt a kedvezőtlen változások kumulált összhatása. Definíciójuk szerint a 100 pontosra konvertált élettel való elégedettség skála 70 pont és a fölötti tartományában elhelyezkedők voltak azok, akik a negatív külső változások ellenére is képesek voltak a szubjektív jóllétük 
átlagos szintjének fenntartására. Az 50 pont alattiak egyértelmủen erre nem voltak képesek, esetükben a kedvezőtlen külső változások és az egyéni problémamegoldási képesség közötti egyensúly felborult, míg az 50-70 pont közöttiek e két típus vegyes csoportját alkották. Az elmélet segítségével a szerzők lehetséges teóriákat fogalmaztak meg arra vonatkozóan, hogy külső negatív, vagy akár pozitív behatás esetén a szubjektív jóllét az egyénre jellemző tartományától eltér-e és ha igen, mennyi idő után tér ahhoz vissza. Ezt több tényező határozza meg szerintük, amelyek közül kettőt emelünk itt ki a válság, mint negatív külső változás következményeinek mikro-szintü vizsgálatához kapcsolódóan. Tehát meghatározzák az egyén külső (1) és belső ,erőforrásai” (2), amelyek támaszt jelentenek a problémamegoldás, a nehézségekből való kilábalás, a kedvezőtlen változásokhoz alkalmazkodás folyamatában. Ezek az egyén közvetlen (családi, baráti) kapcsolatai, az anyagi (jövedelmi) körülményei, és az egyén optimista beállítottsága. A külső támogatást biztosító első kettő tényezőnek egy bizonyos anyagi, kapcsolati erőforrásellátottsági szint alatt van jelentős, a szubjektív jóllétnek a válság éveiben bekövetkező romlását kiegyenlítő szerepe. Azonban, ezen tényezők szerepe egy magasabb erőforrás ellátottsági szinten minimálisnak tekinthető. A belső erőforrás, az optimizmus általában egy pozitív adaptációs technikának tekinthető a nehézségek leküzdésében, azonban az alacsony kiinduló szubjektív jóllétszinten lévők esetében a túlzott optimizmus mást jelenthet. A szerzők szerint az inkább az egyén által kezelhetetlen helyzetre adott érzelmi reakciónak és egyfajta helytelen alkalmazkodásnak tekinthető. Az empirikus eredményeik azt mutatták, hogy míg a válság éveinek kedvezőtlen hatása a magas kiinduló szubjektív jólléttel rendelkezők körében alig okozott jelentős romlást, addig az 50 pont alattiak körében viszont, az eleve alacsony szint miatt, nem eredményezett további jelentős csökkenést. A vegyes csoport esetében pedig a válság kedvezőtlen hatása a hosszú távon még az egyéni erőforrások által kezelhető mértékű, a „,set-point” tartományban maradó változást eredményezett csupán. Cummins és szerzőtársai e magyarázattal indokolták, hogy a gazdasági válság hatása nem eredményezett lényeges eltérést a szubjektív jóllét mértékében az ausztrál lakosság körében.

A válság hatását elemző tanulmányok között, Helliwell és munkatársai (2014) kutatásukban arra keresték a választ, hogy a társadalmi tőke mennyiben tompította a 
2007-2008-as válság szubjektív jóllétre kifejtett negatív hatását. Vizsgálatukban amerikai, dél-koreai és OECD országok adatait elemezték, és a szubjektív jóllétet a boldogság globális mutatójával mérték, a társadalmi tőkének pedig a következő két indikátorát dolgozták ki. Míg az egyik a helyi kapcsolatokat vette számba (család, barátok, szomszédok, egyházi tagság), addig a másik tágabb körben (önkéntes szervezetekben való tagsággal, parlamenti választásokon részvétellel) mérte a ezt a típusú erőforrást. Továbbá e két mutató kompozit indikátorát is bevonták az elemzésükbe. Első lépésben az amerikai adatokat külön elemezték, mert itt a társadalmi tőke mutatóit településszinten alakították ki, a válság negatív hatását pedig a településszintü munkanélküliségi rátával mérték. Az eredmények azt mutatták, hogy azoknál a településeknél, ahol az összevont társadalmi tőke index magasabb volt, ott a munkanélküliség szubjektív jóllétet csökkentő negatív hatása kevésbé érvényesült. A további eredmények közül a válság előtti és utáni időszakot összehasonlító elemzésükre térünk ki még itt röviden, mely során az európai országok adatait elemezték 2002-2010 között. Az elemzés ezen részében a kutatók két országcsoportot, az átmeneti gazdaságok és a nem átmeneti gazdaságok csoportjait vetették össze. Ez esetben a társadalmi tőkét a társadalmi bizalom mértékével, illetve a jogrendszerben és a rendőrségben való intézményi bizalom mértékével mérték, míg a szubjektív jóllétet az élettel való elégedettség és boldogság összevont indikátorával. Az eredmények szerint a kilábalás időszakában a fejlett országokban a társadalmi bizalom a szubjektív jóllét első számú alakító tényezője volt, szemben a gazdaság állapotát kifejező egy főre jutó GDP-vel, míg az átmeneti gazdaságok esetében fordított összefüggést találtak, kevésbé a társadalmi bizalom, inkább az egy főre jutó GDP szerepe volt meghatározó.

A nem átmeneti gazdaságok közül Izland esete azért érdekes, mert éppen a pénzügyi piacok 2008-as összeomlását megelőző években ért el az ország rövid távon olyan gazdasági fellendülést, mint ami Írországban volt tapasztalható 1994 és 2001 között (Madden, 2011). Ezért a válság kirobbanása és vele együtt az izlandi bankrendszer összeomlása sokkal erősebb sokkot és gazdasági visszaesést eredményezett Izlandon, mint más nyugat-európai országokban (Gylfason et al., 2010). Gudmundsdottir (2013) önkitöltős kérdőíves adatok alapján vizsgálta meg a szubjektív jóllét alakulását a jóllét egy-itemü indikátorának, a boldogság 
mutatójának alapján a krízis előtti (2007), alatti (2008) és utáni (2009) években. Az eredmények azt mutatták, hogy a mély recesszió nem eredményezett olyan mértékü csökkenést az izlandiak szubjektív jóllétében, mint amilyenre a szerző számított a kutatás kezdetén. A kétváltozós összefüggések szerint a válságot követően 2009-ben a társadalomban a legboldogabbak a házasok voltak, a legkevésbé boldogok pedig a munkanélküliek és azok, akik számára nehéz vagy nagyon nehéz volt a megélhetés. A szocio-demográfiai mutatók kevéssé magyarázták a boldogság alakulását, azonban a közvetlen kapcsolatokkal (család, barátok) és egészséggel való elégedettséget mérő változóknak a bevonását követően a modellben szereplő materiális változók (jövedelem, munkanélküliség) mellett csupán a szubjektív anyagi helyzet maradt egyedül meghatározó tényező. Azt, hogy 2009-ben miért nem tapasztaltak nagyobb visszaesést a szubjektív jóllétben Izlandon, a szerző a válság kirobbanását követően bevezetett aktív foglalkoztatáspolitikai eszközök és célzott programok szerepével, illetve a banki hitelek hosszabb távra történő átütemezésével, illetve a közvetlen családi és baráti kapcsolatok támogató szerepével magyarázta. Mindezekhez az az összefogásérzet is hozzájárult Gudmundsdottire szerint, amelyet ebben a krízishelyzetben az izlandiak mutattak, s ami 2009-re a boldogságátlag javulását és az érzékelhető gyors adaptációt eredményezte az országban. Későbbi vizsgálatuk, melyet az ESS 2000-2010 közötti adatállományokból kiválasztott adatokon végeztek, ezen korábbi feltevésüket támasztották alá, nevezetesen a családi támogatás, a szülőkkel együtt töltött idő a válság időszakában jelentősen javította az egyéni jóllét mértékét (Gudmundsdottir et al., 2016).

A közgazdaságtani megközelítéseken alapuló korábbi szakirodalom felhívta a figyelmet arra, hogy a szubjektív jóllét körében végzett vizsgálatok eredményei a társadalmi intézmények müködéséről közvetlen visszajelzést adnak a társadalompolitika alakítói és a döntéshozók számára. Egyes kutatók empirikusan igazolták, hogy a kormányzás stabilitása pozitív kapcsolatban áll az állampolgárok jóllétével (Frey-Stutzer, 2001). A gazdasági válság időszakában a válságkezelést célzó kormányzati intézkedések szerepének vizsgálata így napirenden volt a szubjektív jóllétvizsgálatok körében. Az európai kormányok több-kevesebb sikerrel avatkoztak be a makrofolyamatokba, melynek következtében egyes országok rövidebb, míg mások hosszabb idő alatt lábaltak ki a válságból. Ezen központi 
beavatkozások hatását vizsgálta meg a lakosság élettel való elégedettségére, mint a szubjektív jóllét átfogó (proxy) mutatójának alakulására vonatkozóan Bjørnskov (2014). Hosszú távú adatsorok elemzésével, két közgazdaságtani elméletet alapul véve arra kereste a választ, hogy egyes országokban miért történt látványos csökkenés a lakosság átlagos szubjektív jóllétében a válságkezelés évei alatt, míg más országokban ez nem volt tapasztalható. Az egyik teória a Keynes-i közgazdaságtani megközelítés volt, mely szerint a piac egyenetlen müködését állami beavatkozások útján szükséges kiegyenlíteni. A másik a liberális tradícióhoz sorolt osztrák iskola teóriája, ami azt mondja ki, hogy a piac, képes kezelni a gazdasági kihívásokat, és a gazdaság egyensúlyban tartásához elegendő a szabadverseny és a piacgazdaság működését garantáló jogintézmények biztosítása. A szerző kutatásában az Eurobarometer felvételeinek adatait elemezte, és az élettel való elégedettség átlagainak évről évre mért változásait -egy plusz késleltetett, előző évi elégedettségi függő változó bevonása mellett-, több összevont mutató hatásaként értelmezte (így pl.: az egy főre jutó GDP vásárlóerő-paritással kiigazítva, ennek éves növekedési rátája, illetve a kormányzat méretét, a kormányzati ideológiát, a jogi szabályozások minőségét, a központi intézkedések mértékét, az üzleti nyitottságot, a relatív befektetési árszínvonalat, és a társadalmi bizalmat mérő indexek). Az eredmények alapján Bjørnskov arra a következtetésre jutott, hogy a szubjektív jóllét azokban az országokban nem csökkent elsősorban, ahol csekély számú állami beavatkozás, vagy piac-konform szabályozás valósult meg, szemben azokkal, ahol jellemzően szigorú központi beavatkozásokkal igyekeztek a recesszió hatásait ellensúlyozni és a gazdasági egyensúlyt helyreállítani. Ugyanakkor összefoglalásában megállapította, hogy az európai lakosság szubjektív jóllétének alakulását az országok politikai berendezkedése, a kormányzati gazdasági ideológiák és az elemzésében szereplő indikátorok mellett egyéb tényezők is befolyásolhatták, mint például az egyes nemzetek kulturális jellemzői.

A továbbiakban a válságot elemző irodalmak közül kettő hazai kutatást említünk meg, melyek közül az első a szubjektív tényezők fontosságára, míg a második az átmeneti, időszakos érzések szerepére hívja fel a figyelmet az egyéni jóllét alakulásával kapcsolatban. A szubjektív jóllét meghatározó összetevőit feltérképező hazai kutatás az egyéni életkörülmények (szegénység, jóllét) 
összetételében és az összetevők struktúrájában bekövetkezett változásokat vizsgálta Magyarország észak-keleti régiójában, a 2008-as gazdasági válság előtti és azt követő időszakok összehasonlításával (Siposné, 2016). Borsod-Abaúj-Zemplén megyében, a kulturális háttérre is érzékeny kötetlen listás módszer alapján összegyüjtött, 2007-es és 2011-es adatok komparatív elemzése szerint a felsorolt tényezők összetétele a válságot követően nem változott. Mindkét időszakban az életkörülmények egyéni értékeléseit alapvetően a materiális értékek (jövedelmi helyzet, család, biztonság, egészség) határozták meg. A válságot követően az összetevők súlya és jelentősége néhány aspektus tekintetében módosult csupán. Amíg a demográfiai jellemzők mindkét időszakban azonos módon, kevésbé meghatározó szerepet töltöttek be, addig a válság utáni időszakban a jövedelem, a munkanélküli státusz és a szubjektív anyagi helyzet hangsúlyosabbá váltak az életkörülmények és az egyéni jóllét szubjektív értékelésében.

A bevezetőben említettük azt az Eurobarometer vizsgálatot, amely felhívta a figyelmet a válság kedvezőtlen hatásai között a negatív érzéseknek, az eltérő frusztrációnak és a stressznek a megerősödésére. A válság kirobbanását követő évek adatait elemezte Utasi (2011) Európa 24 országában és eltérő régióiban. A válság miatt jelentősebbé vált munkahelyi stressznek és az otthoni munkavégzésnek a boldogság alakulására kifejtett hatását vizsgálta. Az eredmények alapján a szerző megállapította, hogy a fejlett, jóléti európai társadalmakban általában kisebb a munkahelyi stressz mértéke. De a kettős terhelésből adódó konfliktusok okozta negatív munkastressz mértéke is alacsonyabb ezekben a családokban. Azonban Közép-Kelet-Európában, így hazánkban is, a demográfiai csoportok közül elsősorban a házasok és körükben is a nők körében volt a legelterjedtebb az öt dimenzió együttes hatásaként mért negatív stressztípus. Ez az öt dimenzió a következő volt: ,,a háztartási munka miatti időhiányból adódó stressz; a munkahelyi vezetői kontroll miatti feszültségérzet; a munkateljesítményt csökkentő családért érzett aggódás, illetve felelősségérzet; az otthoni tevékenységek végzését akadályozó munka utáni kimerültségérzet; a munkahelyről hazavitt problémák miatti feszültségérzet" (Utasi, 2011:247). A negatív munkastresszt ugyanakkor az otthoni produktív tevékenységből eredő pozitív hatások, az ebből eredő önbizalom, megbecsültségérzet jelentősen ellensúlyozhatják, egy kedvezőbb érzelmi egyenleget eredményezve ezáltal, ami a stressz egészségi állapotra kifejtett kedvezőtlen hatását 
és az egyén szubjektív életminőségét kedvező irányba befolyásolhatják.

\subsection{A szubjektív jóllét mérésének megbízhatósági és érvényességi kérdései}

A társadalomtudomány standardjai szerint a mérésnek az operacionalizált koncepcióra kell pontosan reflektálnia (Babbie, 1996). A kutatás számára kialakított többdimenziós indikátorral kapcsolatosan már kitértünk a megbízhatóság és érvényesség kérdéseire. Azonban a szakirodalom alapján láthattuk, hogy az alkalmazott mérések gyakran ellentmondó eredményekre vezettek, ezért néhány példán keresztül ebben az alfejezetben a megbízhatósági és érvényességi kérdések további empirikus teszteredményeit mutatjuk be.

Panelvizsgálatok tanúsága szerint az élet globális értékeléseire adott válaszok (élettel való elégedettség, boldogságérzet) ugyanazon személyek esetében, meghatározott idő elteltével megváltoztak, köszönhetően a megkérdezett életében bekövetkezett személyes életbeli változásoknak. Campbell és társai (1976) idézett kutatásukban a szubjektív életminőség mérésére egy ún. Jóllét-Indexet készítettek, melynek megbízhatósági szintje az első adatfelvétel utáni nyolc hónap elteltével a korábbi magas megbízhatósági szintről lecsökkent, csupán 0,53 (Ch. Alfa) volt. A csökkenést a szerzők szerint mérési hiba, illetve a személyeknél bekövetkezett állapotváltozások okozhatták. Argyle és Martin (1991) a boldogság mérésére az ún. Oxford Happiness Inventory méröeszközt dolgozta ki, melynek magas megbízhatósági értéke öt hónap elteltét követő tesztelés után relatíve kedvező $(0,67)$ maradt. Jóllehet, ha egy szubjektív értékelésre irányuló kérdést felteszünk a kérdőív elején, illetve a végén, lehetséges, hogy eltérő értéket kapunk. Headey és Wearing (1989) a már említett korai vizsgálatában így jártak el, majd az élettel való elégedettség kérdéseit (mind a kérdőív elején, mind a végén lekérdezett itemeket) a kialakításra kerülő szubjektív jóllét mérésére szolgáló összetett mérőeszközükbe bevonták, tekintettel arra, hogy a megismételt kérdések közötti korreláció alacsony volt $(\mathrm{r}=0,42)$. Az így létrehozott összetett élettel való elégedettségi index megbízhatósági együtthatója így meglehetősen magasnak bizonyult $(0,92)$. A dolgozatban a kutatáshoz kialakított összetett szubjektív életminőség index érvényességének vizsgálatai is hasomlóan magas megbízhatósági együttható 
értékeket mutattak.

A boldogság kérdését szociológiai felvételek gyakran alacsonyabb, pl.: négy vagy három-fokozatú skálán mérik, melyekkel összehasonlítva a 11 fokú skálák nagyobb megbízhatóságot mutattak. A kutatások megállapították, hogy a háromfokú skálák (nagyon boldog, boldog, boldogtalan) esetében a boldogok és a boldogtalanok számos társadalmi-demográfiai jellemző mentén szignifikáns eltérést mutattak, azonban a boldogok és nagyon boldogok csoportjáról ez nem mondható el. Összességében tehát azt mondhatjuk, hogy a boldogsággal és az élettel való elégedettséggel kapcsolatos egyszerü kérdések a surveyekben kevésbé megbízhatóak, mint a skálák, vagy az összetett kérdéssorok (Lim, 2008).

Az érvényesség fő kérdése, hogy mi az amit mérünk tulajdonképpen, illetve a kutatási kérdésünkkel azt a társadalmi tényt mérjük-e, amire kiváncsiak vagyunk. A szubjektív jóllét esetében mit szeretnénk mérni? Egy jellegzetességet, egy olyan valamit, ami folyamatosan jelen van különbözö élethelyzetekben, vagy egy speciális életkörülmény eredményeként fellépő hangulatot, állapotot vagy attitüdöt? Campbell eredményei ellenére több kutatás is ugyanazt mutatta ki, mint például Headey és Wearnig (1989) ausztráliai paneladatokon végzett elemzése. Nevezetesen, hogy a boldogság és az élettel való elégedettség meglepően állandó jellemzőnek tekinthetőek, mind az idő (hat éves paneladatokon), mind a szituációk tekintetében (pl. megkérdezettek egy csoportjának hangulata munkában és szabadidőben). Természetesen az egyén hangulata vagy boldogságérzete változhat az időjárás változásával is, de az emberek hangulata, vagy az életükről alkotott érzelmi vagy intellektuális értékelése nem redukálható le koncepcionálisan egy átmeneti érzelemváltozásra. Az érvényesség kritériuma ugyanakkor felveti az érvénytelenség kérdését. Az érvénytelen válasz azt jelenti, hogy a megkérdezett nem a valós, igazi, belső világával összhangban lévő válaszát adja. Ennek több oka lehet. Vannak olyan emberek, akiknek nincs különösebb fogalmi képzetük a boldogságukról, vagy nem gondolkoztak még el azon, hogy az életük kielégítő vagy sem, így a kérdésnek számukra nincs jelentése. Ahogy Veenhoven (1993) megállapítja, a boldogsággal és az élettel való elégedettséggel kapcsolatban feltett egyszerű kérdésre gondolkodás nélkül adnak választ az emberek. Ugyanakkor azt is megállapította, ahogyan Andrews és Withey korábban idézett 1974-es munkájukban, hogy a válaszadók 
jelentős mennyiségü magyarázatot igényeltek a kérdések megválaszolásához. Vannak olyan emberek is, akiknek léteznek elképzeléseik a boldogságról és boldogtalanságról, és az életük természetéről, de nem tudják megragadni azokat. Nem tudnak hozzáférni a belső érzéseikhez, így számukra problémát jelent azokról beszélni. Az is megtörténhet, hogy a kérdezés során egy korábbi kérdés által kiváltott hangulat befolyásolja a válaszokat. Ezt az a kognitív elmélet magyarázza (the availability heuristic), mely szerint a megértés, ami azonnal elérhető a tudat számára, átszínezi az attitüdöket. Schwarz és Strack (1991) kutatásában ezt a megállapítást támasztják alá, amikor arról számolnak be, hogy egy pozitív érzéseket kiváltó kérdésblokk bizony javíthatja a megválaszolt szubjektív jóllét szintjét. Diener és Suh (1999) vizsgálatai szerint a szubjektív jólléttel kapcsolatos kérdésekre adott válaszokat nem befolyásolta túlságosan gyakran a válaszadó pillanatnyi kedélyállapota. Az érvényességgel kapcsolatos másik probléma, hogy az emberek azt hiszik, hogy a társadalmilag elfogadott válaszok kívánatosabbak, mint az igazság. Ez a hit a kollektivista kultúrán alapul, de gyakran előfordul individualista társadalmakban is. Amíg Veenhoven (1993) kimutatta, hogy a szubjektív jóllét kérdéseire adott válaszok relatíve függetlenek a társadalmi elvárásoktól, addig Diener és Suh (1999) arról számolt be, hogy a fiatalabb válaszadók boldogabbnak és kevésbé depressziósnak tünnek a kérdezőbiztosnak adott válaszaik alapján, mint az önkitöltős tesztekben adott válaszaik szerint. Diener és Lucas (1999) kutatásában a társadalmilag kívánatos válaszok problémáját a személyiségről és a szubjektív jóllétről adott válaszok alapján vizsgálta meg. Szerintük az emberek különféle ingerekre adott válaszkészlete biológiailag és a korai szocializáció elmélete szerint determinált, mert hiába adaptálódott az emberek jutalmazás és büntetés rendszere a pozitív és negatív társadalmi ingerekhez, az egyén egy idő után önkéntelenül visszatér a saját szubjektív jóllétének az alap-kritériumaihoz. Mindezeken kívül az emberekre hatnak az olyan általános vélekedések is, mint például az optimista elfogultság (nézd mindennek a jó oldalát), vagy a kételkedő beállítottság (minden lehetséges és annak az ellenkezője is), illetve az ideológiai beállítottság, amikor az adott ideológiának megfelelő eredmény megszületése okoz boldogságot az egyén számára. Lucas és munkatársai (1996) kutatásukban e fenti problémák kiszürése érdekében a megkérdezettől független személyek értékelését is figyelembe vették (szülők, barátok, tanárok, más személyek, akik a válaszadót jól ismerik). 
Eredményeik azt mutatták, hogy a fenti beállítottságok nem rombolták le a szubjektív jólléttel kapcsolatos válaszok érvényességét, mivel a válaszadónak a boldogságra és elégedettségre adott válaszai összefüggtek a szubjektív jóllét fogalmi köréhez tartozó olyan értékeléseikkel, mint az önbecsülés, az önkontroll mértéke és a jövőbe vetett bizalom. 


\section{A kutatás hipotézisei}

\subsection{Bevezetés}

Kutatásunkban a gazdasági válság hatását vizsgáljuk a szubjektív életminőség és annak meghatározó társadalmi-demográfiai tényezőinek vonatkozásában, összevont keresztmetszeti adatokon, többváltozós statisztikai eljárások alkalmazásával. A magyar lakosság szubjektív életminőségének alakulását a II. fejezetben bevezetett fö elméleti megállapítások alapján a válság elötti és utáni időszakok összevetésével, majd a családi állapot, a munkaerő-piaci jelenlét, a szubjektív egészségi állapot, a szubjektív jövedelmi helyzet, a biztonságérzet, és a személyes jellemvonás alapján kialakított csoportok vizsgálata, illetve az anómia és elidegenedésérzet elterjedtségének mérése útján elemezzük, melyekre az alábbi alfejezetekben megfogalmazott hipotéziseket írjuk fel. A hipotézisek vizsgálata alapján elemzésünk egyrészt leíró jellegü, amikor a szubjektív életminőség skála alapján a főbb társadalmi, demográfiai nagycsoportokat jellemezzük. Másrészt analitikus természetű, amikor azt vizsgáljuk, hogy a válság évei befolyásolták-e, és ha igen, milyen irányban és mértékben a lakosság szubjektív életminőségét meghatározó fő dimenziók realizációs szintjeit, illetve a kutatás számára kialakított többdimenziós életminőség indikátor alapján az eltérő társadalmi nagycsoportok életminőségbeli különbségeit.

\subsection{A gazdasági válság hipotézise}

Magyarországon a gazdasági válság kedvezőtlen hatásai 2009-ben váltak érzékelhetővé, amelyet az elhúzódó kilábalás évei, vagy, ahogyan a szakirodalom nevezi, a „második válságidőszak” követett (Clench-Aas\&Holte, 2017). A válság és annak kezelését szolgáló intézkedések kedvező hatása 2012-őt követően, a 2013-as évtől mutatkoztak meg makro- és mikro indikátorok alapján. A vonatkozó kutatások szerint, ahogyan a bevezetőben már említettük, hazánkban a 2012-es évig folyamatosan emelkedett a szegénységi ráta értéke, és nőtt az anyagi deprivációban élők teljes népességen belüli aránya. A 2013-as évtől azonban már láthatóak voltak a magyar gazdaság és társadalom talpra állásának jelei, ahogyan ezt a GDP 
volumenindexe, az infláció alakulása és a munkanélküliségi ráta javuló értékei is jelezték (1. sz. táblázat). Ugyanakkor a kutatás fő hipotézisének megfogalmazásakor magunk sem hagyatkozhatunk a makromutatók által kirajzolódó tendenciákra. Jóllehet korai kutatások igazolták, hogy az infláció növekedése az általános jóllét csökkenésével jár együtt. Kutatók becslése szerint 5\%-os emelkedés, az egyéb gazdasági-társadalmi jellemzők és a munkanélküliségi ráta kontrollálása mellett 0,05 egységnyi átlagos elégedettségi szint csökkenést eredményez, vagyis a populáció 5 százaléka átkerül az „életével nagyon elégedett” kategóriából a „meglehetősen elégedett” kategóriába (Oswald, 2003). Azonban tény, hogy a kelet-európai térség posztkommunista országainak élettel való elégedettsége az átmenet utáni évekre valamelyest javultak, azonban más életterületekkel, mint a munkával, az egészséggel, a szomszédsággal és a családdal való elégedettség értékei azonban lecsökkentek. Egy tágabb időintervallumon tett összehasonlításkor azonban az élettel való elégedettség mégsem mutatott javulást, Magyarországon például 1982-ben az elégedettség átlaga 6.93, 1990-ben 6.03, míg 2005-ben 6.30 volt. A rendszerváltozás időszakára eső csökkenést a gazdasági recesszió, illetve az anómia elterjedtségének növekvő mértéke magyarázta. Tehát az egyéni életminőség nem csak az anyagiakhoz kapcsolódik, hanem egyéb életterületekhez és olyan mindennapi érzelmi és pszichés folyamatokhoz is, melyek jóllétünket szintén meghatározzák (Easterlin, 2009). Azonban a szakirodalom alapján láttuk, hogy a lakosság gyors alkalmazkodása folytán a válság nem minden országban okozott jóllétcsökkenést (Graham-Oswald, 2010), tehát, ahogyan a bevezetőben jeleztük, lehetséges, hogy nem fogjuk tudni mérni a hatását. Mindazonáltal, a tapasztalati tények (1. ábra), a makromutatók alakulása (1. táblázat) és a szakirodalom alapján tehát azt várjuk, hogy Magyarországon a válság éveiben a lakosság átlagos szubjektív életminősége csökkenni fog. Vajon az adataink is ezt mutatják? Valóban csökkent 2012-re Magyarországon az átlagos szubjektív életminőség? Kutatási kérdéseink megválaszolásához a kutatás fő hipotézisét az alábbiakban fogalmaztuk meg:

Hipotézis 1.: A gazdasági válságot követően a magyar lakosság szubjektív életminősége csökkent. 


\subsection{A társadalmi integráció hipotézisei}

Layard boldogságról írt tanulmánya szerint ,a boldogságot befolyásoló összes tényező közül az első helyen a családi élet vagy más közeli kapcsolatok állnak" (Layard, 2007:176). A makroszintű folyamatoknak a hatásait, a válság által megnövekedett kockázatokat és veszélyeket az intézményrendszerek (foglalkoztatási-, oktatási rendszerek, jóléti rendszerek, család) megszürik és eltérő hatásfokon és következményekkel közvetítik az egyének, illetve egyes társadalmi csoportok felé (Blossfeld-Mills, 2005). A család a társadalom alapegysége, általa biztosított funkciók (instrumentális, emocionális funkciók) okán az egyik legerősebb társadalmi integrációs mechanizmust nyújtja. Azok, akik családban, házasságban élnek mindig kedvezőbb egyéni jóllétről adnak számot, mely összefüggést elsősorban a családból és a házasságból adódó biztosabb jövedelmi és egzisztenciális körülmények magyaráznak. A házasság és a boldogság pozitív kapcsolatát több empirikus vizsgálat is igazolta, a házasok mindig magasabb szubjektív jóllétről számoltak be, mint azok, akik soha sem voltak házasok. A házasok jobb fizikai és pszichés állapottal rendelkeznek az egyedülállókhoz képest, és magasabb a várható élettartamuk. Kutatások ugyanakkor megállapították azt is, hogy a házasok körében a házasságkötést követően csökken az élettel való elégedettség mértéke (Frey és Stutzer, 2003a, 2003b). Ez magyarázható egyrészt az adaptációs elmélettel, miszerint az emberek nem lehetnek folyamatosan boldogok, mert a körülmények akár pozitív, akár negatív változásához hozzászoknak és visszatérnek egy érzelmileg közömbös állapotba. Másrészt, az az empirikus eredmények arra is rámutattak, hogy azok, akik életútjuk későbbi szakaszában kötöttek házasságot, a házaséletük későbbi időszakában magasabb szubjektív jóllétről számoltak be, mint azok, akik fiatal éveikben házasodtak össze (Frey-Stutzer, 2004). A házasságnak a szubjektív életminőségre kifejtett kedvező hatására már a legkorábbi jóllét-kutatások is rámutattak (Diener et al., 1999) (4. ábra). 
4. ábra: A házas és nem házas nők és férfiak szubjektív jólléte, 1972-1989 (Forrás: Diener et al., 1999: 290)

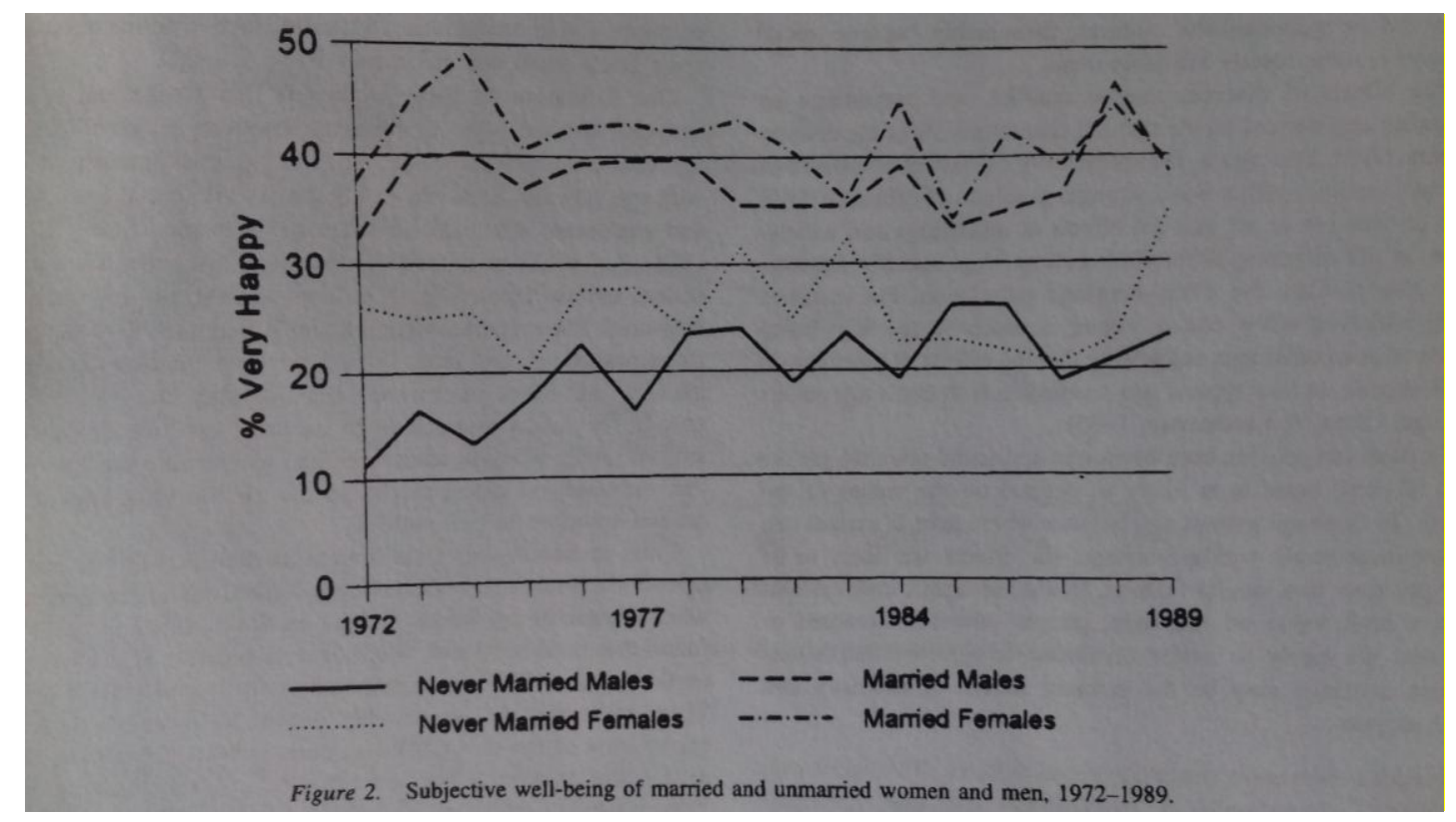

A pozitív összefüggést a 2000-es évek elemzései szintén igazolták, magasabb szubjektív jóllétről adtak számot azok, akik házasok voltak, vagy tartós párkapcsolatban éltek (Oswald-Wu, 2009; Blanchflower-Oswald, 2011). Az egyedülállók körében, elsősorban az özvegyek és az elváltak azok, akik a szakirodalom szerint jelentős szubjektív jóllétcsökkenést mutattak a hozzátartozó elvesztését vagy a házasság, élettársi kapcsolat felbomlását követően. Az idő előrehaladtával azonban az alkalmazkodás nem következett be teljes mértékben, az elváltak és megözvegyültek egyéni jóllétszintje nem tért vissza a korábbi átlagos szintre, hanem egy alacsonyabb átlagérték körül stabilizálódott (Luhmann et al., 2012). A válság évei mind a házasságban, élettársi kapcsolatban élőkre, mind az egyedülállókra jelentős anyagi és érzelmi terhet róttak, így a házasság kedvező funkciói okán és az empirikus összefüggések tükrében a következő hipotézist fogalmaztuk meg:

Hipotézis 2.a.: A válság után nőtt a szubjektív életminőségben mutatkozó különbség a házasságban (élettársi kapcsolatban) élők és az egyedülállók között. 
A fejlett ipari társadalmakban a társadalmi kockázatok vonatkoztatási egysége már nem a korábbi csoport, az osztály, vagy a réteg, hanem az individualizálódó társadalomban magára maradt „piaci egyén”, a társadalmi struktúrában elfoglalt helyéből adódó életkörülményeivel. A gazdasági válság után felerősödő strukturális egyenlőtlenségek a modern társadalmakban a „társadalmi kockázatok individualizációjává fogalmazódnak át”, olyan egyéni életútproblémákká, amelynek következtében „a társadalmi problémák közvetlenül pszichés diszpozíciókba csapnak át: személyes elégtelenségérzésbe, büntudatba, szorongásokba, konfliktusokba és neurózisokba" (Beck, [1985] 2003:133). A válság egyik következménye hazánkban is a munkanélküliség és szegénység kockázatainak emelkedése volt, melyről a bevezetőben számoltunk be. A munkaeröpiaci kockázatok elsősorban a fiatalokat sújtották, körükben 2012-re 28\%-ra emelkedett a munkanélküliségi ráta mértéke. A válság előtti szakirodalomban természetesen a munkanélküliség ugyan úgy a szubjektív jóllét egyik fő magyarázó indikátoraként jelent meg. Kutatások szerint a munkanélküliség az, ami a fő forrása a depressziónak és boldogtalanságnak (Oswald, 1997). Későbbi vizsgálatok is a munkanélküliség és a szubjektív jóllét negatív kapcsolatát igazolták. Az azonos szocio-demográfiai jellemzőkkel rendelkező egyének között a munkanélküliek jóval boldogtalanabbak voltak, mint azok, akiknek munkájuk volt. E negatív hatás mértékét csökkentette, ha a munkanélküli partnere is munkanélküli volt, vagy a szükebb környezetében (vonatkoztatási csoportjában) is voltak munkanélküliek (Oswald, 2003). Ahogy a közgazdász Layard átfogó esszéjében megállapítja, a munkanélküliség „,csökkenti a jövedelmet, de közvetlenül is csökkenti a boldogságot azáltal, hogy lerombolja az egyén önbecsülését, és megszünteti a munkája során szövődött közösségi kapcsolatait” (Layard, 2007:74). A munkanélküliségből eredő frusztráció a boldogság egyik legerősebb hatással bíró magyarázó tényezője, amelyet panelvizsgálatok mutattak ki. A 24 ezer fős, 15 évet átfogó német háztartáspanel felvétel alapján a kutatók megállapították, hogy azok az egyének, akik korábban munkanélküliek voltak, nem reagáltak kevésbé negatívan az újabb munkanélküliségre, mint azok, akik még sosem voltak állástalanok (Lucas et al., 2004). További panel-kutatások is ezt erősítették meg, a munkanélküliség, akár többszöri alkalommal állt fenn az életút folyamán, akár tartósan, hosszú távú negatív hatása kimutatható volt a boldogság alakulását magyarázó modellekben (Headey et 
al, 2014). Empirikus vizsgálatok arra is rámutattak, hogy a munkaerö-piaci integráció hosszabb távú sikertelensége, és az azzal járó elszigetelődés és magány lelki sérüléseket okozhat, és olyan félelmeket alakíthat ki az egyéekben, melyek csökkentik a sikeres elhelyezkedés esélyeit (Di Tella et al., 2001).

Kutatásunkban a munkaerö-piaci jelenlét alapján alakítottuk ki a dichotóm társadalmi csoportokat: dolgozik - nem dolgozik. A nem dolgozók csoportjába a munkanélkülieken túl a diákok, a nyugdíjasok, a háztartásbeliek és egyéb, munkaerő-piacon kívüli tevékenységet végzők is szerepelnek. Nemzetközi összehasonlító vizsgálatok szerint ezen utóbbi három inaktív csoport közül a diákok a leginkább elégedettek az életükkel és ők a legboldogabbak, ezt követően a háztartásbeliek, majd a nyugdíjasok azok, akik legkevésbé elégedettek és boldogok (Blanchflower-Oswald, 2011). A gazdasági válság mind a munkaerő-piacon jelen lévők, mind az ott jelen nem lévők helyzetét kedvezőtlenül érintette. Azonban a munkanélküliségnek az egyéni jóllétre kifejtett negatív hatását a gazdasági válság hatását elemző szakirodalmak körében már bemutattuk, több esetben Magyarországot érintően is, ezért azt itt nem kívánjuk megismételni. Kutatásunkban a munkanélküli státusz helyett a munkaerö-piaci jelenlétet vettük alapul, és a szubjektív életminőség összefüggésével kapcsolatosan az alábbi hipotézist fogalmaztuk meg. Természetesen figyelembe vesszük az eredmények értékelésekor, hogy 2012-re nőtt a nem dolgozók között a munkanélküliek aránya, mely arányváltozás a kedvezőtlenebb, míg a tanulók jellemzően átlagosan magasabb jóllétértékei a kedvezőbb irányba tolták el a nem dolgozók átlagos szubjektív életminőségét.

Hipotézis 2.b.: A munkaerő-piacon jelenlévők szubjektív életminősége a válság kedvezőtlen hatásának köszönhetően csökkent.

\subsection{A szubjektív egészség, biztonságérzet és jövedelmi körülmények alapján kialakított társadalmi nagycsoportok polarizációjának hipotézisei}

A válság időszakában -ahogyan azt már említettük-, az egyének és háztartások racionalizálják kiadásaikat, és az alapvető szükségletek kielégítésére helyeződik a hangsúly. Az alapvető szükségletekhez a szakirodalom első helyen a 
fiziológiai szükségleteket: az egészséget és a biztonságot sorolja, illetve a jövedelmet és az iskolázottságot, melyekhez egyéb szükségletek, javak és szolgáltatások is természetesen hozzátartoznak (Stewart, 1996). Jóllehet az jó egészségi állapot alapvető kritériuma az egyén saját életéről alkotott szubjektív értékelésének, azonban az eltérő objektív mutatókkal mért egészségi állapot élettel való elégedettség alakulásában játszott szerepe kevésbé volt meghatározó a szakirodalom szerint, mint a szubjektív indikátornak. Az egészséggel való elégedettség meghatározó szerepet játszott az átfogó életminőséggel való elégedettség alakulásában, azonban a szubjektív indikátor hatása közvetett hatásként érvényesült (Michalos-Zumbo, 2002). További kutatások is rámutattak arra, hogy a kedvező szubjektív egészségi állapot pozitív hatást fejkt ki az egyéni jóllét alakulására. Azok, akik kedvezőbben értékelték általános egészségi állapotukat, nemcsak boldogabbak, de elégedettebbek is voltak az életükkel (Spéder-Kapitány, 2002). Magasabb szubjektív jóllétről számoltak be azok az egyének is, akik lakókörnyéküket biztonságosabbnak tartották (Lengyel-Janky, 2003). A lakókörnyezetben megélt fizikai biztonságérzet, vagyis az egyén és a család biztonsága egyéb 'life domain' elégedettségi tényezőkkel szintén pozitív kapcsolatban állt, ahogyan a szubjektív jóllét mértékével is. Amíg az élettel való elégedettséget a biztonságérzet és az egyéb elégedettségi mutatók 31\%-ban, a boldogságot 51\%-ban magyarázták (Michalos-Zumbo, 2000). Mind a jövedelem, mind az anyagi javakkal való ellátottság mértéke, a szakirodalom szerint pozitív összefüggsében áll az élettel való elégedettséggel és a boldogsággal. Azok a kutatások, amelyek az erőforrás-elmélet alapján a szubjektív jóllét alakulását a különböző jövedelemtípusok függvényében vizsgálták, szintén pozitív összefüggést találtak az egyéni jóllét kognitív és affektív mutatóival (Diener et al., 1999; Lelkes, 2003). Kérdés tehát, hogy e három alapvető szükségletfaktor szubjektív életminőségre kifejtett hatását a válság évei befolyásolták-e, és ha igen, akkor milyen irányban és mértékben? A kérdés megválaszolásához és a hipotézisek kialakításához kapcsolódóan, a bevezetőben leírtak és a fentiek alapján, azzal a feltételezéssel élünk, hogy a válság éveiben a háztartások sérülékenységének megnövekedése okán a jövedelmi helyzet szubjektív értékelése jelentősebb meghatározója a lakosság szubjektív életminőségnek (Siposné, 2016). Továbbá feltételeztük, hogy a nehezebb életkörülmények mellett a rossz egészségről számot adó lakososk általános egészségi állapota, egyéni értékelése feltehetően tovább romlott; míg a válság időszakában 
megnövekedett aggodalmak és félelmek várakozásaink szerint a fizikai biztonságérzet szerepét is módosíthatták, ezért kutatásunkhoz az alábbi hipotéziseket fogalmaztuk meg:

Hipotézis.3.a.: A válság éveiben nőtt a szubjektív életminőségbeli különbség azok között, akik kijönnek és akik nem jönnek ki a rendelkezésükre álló jövedelemből.

Hipotézis.3.b.: A válságot követően nőtt a szubjektív életminőségben mutatkozó különbség a jó és a rossz szubjektív egészségi állapottal rendelkező lakosok között.

Hipotézis.3.c.: A recesszió éveiben nőtt a biztonságérzettel rendelkezők és a biztonsághiányt szenvedők szubjektív életminősége közötti különbség.

\subsection{Az egyéni anómia- és elidegenedésérzet hipotézise}

A gazdasági válságok a társadalom és a gazdaság fejlődésének sajátos velejárói, melyek során a társadalmat összetartó kollektív erők veszítenek szabályozó erejükből. Az egyén és a társadalom közötti kötődések fellazulnak és a társadalom normanélküli, anómiás állapotához vezetnek (Durkheim, 1982). Az elidegenedésérzet elterjedtsége, egyes anómiás magatartások, illetve lelki problémák növekvő gyakorisága tehát válságok és társadalmi krízisek idején figyelhető meg. Ilyen krízisidőszak volt a rendszerváltozás előtti időszak is, melyben a magyar társadalom nemcsak gazdasági válsággal nézett szembe, de olyan „erkölcsi és értékválság” is érzékelhető volt, mely az anómia és elidegenedés elterjedtségének növekedését eredményezte a '80-as évek végére (Andorka, 1992:317). A '90-es évek végén azonban a válság tünetei enyhültek, 1993 és 1997 közötti adatokat elemezve kutatók arról számoltak be, hogy csökkent a lelki problémák tüneteinek előfordulási gyakorisága és az anómia elterjedtsége hazánkban, elsősorban a fiatalok, a magas iskolai végzettségűek és a magasabb jövedelmi helyzetü csoportok körében (Spéder et al., 1998). A szakirodalom alapján, a 2008-as gazdasági válság időszakában várakozásaink szerint nőtt az átlagos anómia- és elidegenedésérzet mértéke Magyarországon, melynek tesztelésére az alábbi hipotézist fogalmaztuk meg:

Hipotézis 4.a.:

Magyarországon a gazdasági válság után nőtt az egyéni anómia- és elidegenedésérzet elterjedtsége a lakosság körében. 


\subsection{A személyes jellemvonás hipotézise}

A személyes jellemvonások és az életminőség kapcsolatát az optimista beállítottság és a célok átértékelésére való képesség függvényében vizsgálta meg Wrosch \& Scheier (2003). Feltételezésük szerint a jellegzetes viselkedési minták, melyek személyiségjellemzők által meghatározottak, összefüggenek az egyének eltérő életminőségével. Kutatásaik szerint a pesszimistákkal szemben az optimista beállítottságú emberek sokkal gyakrabban lépnek fel aktív problémamegoldó szerepben és használnak érzelmi adaptációs problémakezelési technikát akkor, amikor a fontos életcéljaikban nem tudnak elörelépést tenni. Ennek következtében az optimisták mindig jobb életminőséget érnek el. A válság, ahogyan a bevezetőben bemutattuk, a családok életében számos olyan kényszermegoldást eredményezett, melyet korábban anyagi gondjaik enyhítésére, problémáik megoldására nem vettek igénybe (pl. személyes vagyontárgyaik értékesítése, barátoktól anyagi segítség kérése). Kérdéses tehát, hogy a nehezebb életkörülmények hoztak-e változást az optimisták és a pesszimisták életminőségbeli különbségeiben? Vajon az eltérő egyéni beállítottság valóban hozzájárult a problémák megoldásához, a krízisidőszak átvészeléséhez javítva ezzel az optimisták helyzetét? A kérdés megválaszolásához az alábbi hipotézist fogalmaztuk meg:

Hipotézis 5.: A válság után nőtt a szubjektív életminőségben mutatkozó különbség az optimisták és a pesszimisták között. 


\section{Adatok és módszerek}

Az elemzéshez az adatokat az Európai Társadalmak Összehasonlító Vizsgálatának (European Social Survey, továbbiakban: ESS) keresztmetszeti felvételei biztosítják. Az adatfelvétel alapját egy minden országban azonos standard kérdőív képezte, melyhez minden alkalommal más és más témakörök kiegészítő moduljai csatlakoztak, bizonyos időközönként rotálódva. Így került 2006-ban és 2012-ben a „Személyes és társadalmi jóllét” („Personal and Social well-being”) témaköre a kutatás fókuszába. A modulhoz tematikusan kapcsolódó szubjektív jóllét alapkérdései (élettel való elégedettség, boldogság) nemcsak az említett modul során, de minden évben a kérdőív standard részét képezték. A minta véletlenszerü mintavétel alapján került kiválasztásra minden országban. Az adatokat a 'design' súlyváltozóval súlyoztuk, mely alapvetően azt hivatott korrigálni, hogy adott ország egyes régióinak/településeinek válaszadói az alkalmazott mintavételi eljárás folytán eltérő valószínüséggel kerüljenek a mintába.

\subsection{Adatok és alkalmazott módszerek}

Az empirikus elemzéshez a tematikus kérdőívblokk alapján kiválasztott 3. és 6. hullámok adatait használtuk, mely adatfelvételt a 2006-os évben a Magyar Gallup Intézet készítette el 2006. november 21. és 2007. január 28. közötti időtartamban (N = 1518 fó), míg a 2012-es felvételt a TÁRKI Társadalomkutatási Zrt. 2012. november 11. és 2013. február 17. között $\left(\mathrm{N}=2014\right.$ fö). ${ }^{6}$ A kutatásban kifejlesztett többdimenziós életminőség indikátort az elméleti koncepció alapján operacionalizált mutatók segítségével, főkomponenselemzés-eljárással hoztuk létre, önállóan, mindkét évre vonatkozóan. Ezt megelőzően megvizsgáltuk az indikátor elemeinek (alskáláinak) jellemzőit és viselkedését a két mintában többváltozós elemzés útján. Majd a kialakított multidimenzionális mérőeszköz alapján a lakosság szubjektív életminőségének alakulását elemztük a társadalmi-demográfiai csoportok mentén a két időszakban. Az önálló mintákon végzett elemzések elkészítésének kettő oka volt.

$6 \mathrm{Az}$ adatfelvételről, a mintavételi eljárásról, egyéb technikai kérdésekről részletes tájékoztatást ad a kutatás dokumentációja, mely elérhető az ESS honlapján: http//:www.europeansocialsurvey.org . 
Első lépésben kiváncsiak voltunk arra, hogy a kiválasztott két évben a felépített modellek hogyan illeszkednek az adatokra, és milyen különbségeket mutatnak azon dichotóm csoportok mentén, melyeket a kutatás számára hoztunk létre, tekintettel arra, hogy az itt kialakított társadalmi nagycsoportok többségének életminőségbeli különbségeit igen kevés vizsgálat kutatta. Másrészt az önálló mintákon elkészített elemzéseket az is indokolja, hogy a Loving dimenzió realizációját mérő skála 2006ban és 2012-ben eltérő megfogalmazásban és skálán került felvételre, azonban a két kérdés tartalmilag a vizsgált jelenséget (támogatottságérzet) ragadta meg, mellyel kapcsolatos indoklás további részleteit az operacionalizációról szóló 4.1-es fejezetben közöljük.

Ezt követően a hipotéziseket az első lépésben többváltozós statisztikai elemzés útján, regressziós eljárásokkal, a legkisebb négyzetek módszerével ${ }^{7}$ teszteltük összevont keresztmetszeti adatokon (pooled cross sectional data), mely eljárás során nem a standardizált, hanem a standardizálatlan regressziós együtthatókat vizsgáltuk. A standardizálatlan együttható ”...azt mutatja meg, mennyivel változik átlagosan a függő változó értéke - a maga természetes mértékegységében mérve -, amint a magyarázó változó - szintén a maga természetes mértékegységében mérve - 1 egységgel változik" (Moksony, 2006:102). Tehát a sztenderdizálatlan B értéke megmutatja, hogy a magyarázó változó egy egységnyi változása a függő változóban milyen átlagos változást idéz elő. Dichotóm magyarázó változók esetében ez kifejezi a válságot megelőző időpontban (2006=0) becsült különbségnek, a válságot követő időpontban $(2012=1)$ becsült különbséggel való összevetésében mutatkozó eltérését, különbségét ${ }^{8}$, vagyis növekedését vagy csökkenését (Buckley-Shang, 2003; National Bureau of Economic Research, 2007). A szubjektív életminőségre az alábbiakban levezetett regressziós-egyenleteket írtuk fel:

\section{A válság hatása a függő változóra összevont keresztmetszeti adatokon (fö}

\section{hipotézis):}

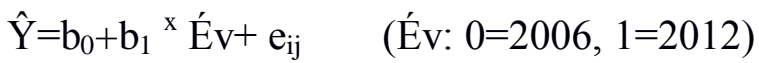

$7 \mathrm{Az}$ eljárás lineáris regresszió, amely a regressziós egyenest a legkisebb négyzetek módszerével állítja elő az $\mathrm{Y}=\mathrm{BX}+\mathrm{C}$ regressziós egyenletek alapján, a tényleges és becsült Yi értékek különbségének összegét minimalizálva, mellyel a legjobban illeszkedő modellt (egyenest) keresi meg. 8 A különbség a különbségekben (diff-in-diff) módszer sztenderd eljárása alapértelmezésben a beavatkozás vagy esemény elötti és utáni állapotot veti össze, amikor a beavatkozás/hatás egyik csoportban érvényesül, míg a másikban (kontrollcsoport) nem. 
Évek értékeinek behelyettesítését követően az egyenlet:

$\hat{\mathrm{Y}}=\mathrm{b}_{0}+\mathrm{b}_{1}{ }^{\times} 0=\mathrm{b}_{0} \quad \rightarrow$ 2006-os évben becsült életminőség

$\hat{Y}=b_{0}+b_{1}{ }^{x} 1=b_{0}+b_{1} \rightarrow 2012$-es évben becsült életminőség

Kivonva a két egyenletet egymásból:

$\hat{\mathrm{Y}}_{2012}-\hat{\mathrm{Y}}_{2006}=\left(\mathrm{b}_{0}+\mathrm{b}_{1}\right)-\mathrm{b}_{0}=\mathrm{b}_{1}$

Ez a különbség az adatfelvétel időpontjainak hatása a szubjektív életminőségre, tehát $a b_{1}$ együttható a válság éveinek a hatását, illetve e hatás nagyságát tükrözi.

\section{A válság hatása egyes magyarázó változókon keresztül - interakciós hatások (további hipotézisek):}

$\hat{Y}=b_{0}+b_{1}{ }^{\times} E ́ v+b_{2}{ }^{x} X_{1}+b_{3}{ }^{\times}\left(E^{\prime}{ }^{\times} X_{1}\right)+e$

$\mathrm{X}_{1}=$ családi státusz ( $1=$ házas, $0=$ nem házas)

$\mathrm{b}_{2}=$ házasok életminősége a nem házasokéhoz viszonyítva

$\mathrm{b}_{3}=\mathrm{a}$ válság hatása a házasoknál.

A fent idézett szakirodalom alapján az egyenletben az $\mathrm{Y}$ a függő változó, melynek $\hat{Y}$ értékét a magyarázó változókkal becsli a modell. Az egyenlet jobb oldalán a »b0«a regressziós egyenlet konstansa (a függő változó átlagos értéke akkor, amikor a magyarázó változó értéke nulla), az »Év« az adatfelvételek időpontja, »b1 « az Év hatása, "X1« a magyarázó változók egyéni szintü paraméterbecslései, »b2« a magyarázó változók hatása; az »ÉvxX1 «az interakciós szorzat, »b3«a válság hatása a magyarázó változókra, ami sztenderdizálatlan B3 együtthatóként a házasok és egyedülállók között lévő azon lehetséges szubjektív életminőségbeli különbséget mutatja, ami a válságnak köszönhető; »e« a reziduum (a tapasztalati és a függvény alapján becsült $Y$ értékek különbségei, vagyis a Ŷ értéktől, tehát a változók közötti átlagos összefüggéstől, a függő változót befolyásoló egyéb tényezők miatti eltérések). A különbség a különbségekben becslés tehát az interakciós tag standardizálatlan beta értéke (B3), ami a következö:

$\mathrm{B}_{3}=\left(\overline{\mathrm{y}}_{\text {házasok2012 }}-\overline{\mathrm{y}}_{\text {házasok2006 }}\right)-\left(\overline{\mathrm{y}}_{\text {nem házasok2012 }}-\overline{\mathrm{y}}_{\text {nem házasok2006 }}\right)$.

A többváltozós lineáris regresszióelemzés kiinduló modellje a kétváltozós egyenlet, 
amely alapvetően a két változó közötti korrelációval egyenlő, melyet a szakirodalom ún. teljes hatásnak nevez. A további magyarázó változók bevonása az egyenletbe azt eredményezi, tekintettel arra, hogy a független változók is hatással vannak egymásra, hogy egy-egy változó hatásában más változók hatásai is megjelennek, amelyet ún. indirekt hatásnak neveznek. Ez az indirekt hatás látható a regressziós együtthatók értékeinek egyes további magyarázó változók bevonását követő csökkenésében. A független változó direkt hatását pedig az integrált (az összes magyarázó változót tartalmazó) modellben megjelenő regressziós együttható értéke fejezi ki. Mindegyik modellt kontrollváltozók nélkül, majd azok bevonásával futtattuk le. Lényegesnek tartjuk kiemelni, hogy a változók közötti ok-okozati összefüggések irányát nem célja jelen kutatásnak vizsgálni, a kiválasztott statisztikai elemzési módszerek csakis az összefüggéseket, a változók közötti együtt-járások erősségét és irányát, azok szignifikáns voltát mutatják ki (Kolosi-Rudas, 1998).

\subsection{Konceptualizáció és operacionalizáció}

Jelen fejezetben első lépésben Allardt $(1973,1993)$ koncepciójának szubjektív definícióit alapul véve, a kutatás számára konceptualizáljuk és operacionalizáljuk a szubjektív életminőséget mérő indikátort. Második lépésben a magyarázó és kontrollváltozóknak az ESS felvételek 2006-os és 2012-es kérdőívei alapján történő specifikálására térünk rá.

Allardt (1973) korai elméletében - ahogyan a korábbi fejezetben már bemutatásra került -, a materiális szükségleteket átfogó „Having” dimenzió az egyének objektív anyagi helyzetét fejezi ki (jövedelem, háztartás lakósürüsége, vagyoni helyzet, stb.), amelynek szubjektív mérőeszközét későbbi munkájában ugyanezen indikátorok által mért egyéni értékelés alapján definiálta a szerző, pl. az életszínvonallal, vagy az anyagi körülményekkel való elégedettség (Allardt, 1993). A szociális szükségleteket átfogó 'Loving' dimenzió a barátság, a szeretet, az összetartozás (kölcsönös törődés és támogatás) fogalmait kapcsolja össze. A 'Being' dimenzióban szintén több fogalom kapcsolódik össze: a személyes fejlődés, az önmegvalósítás és kiteljesedés. Továbbá az eredeti allardti modellben elszórtan elhelyezkedő pozitív és negatív tartalmú érzéseket mérő indikátorokat koncepciónkban a szubjektív életminőség két típusú: tartós és átmeneti érzéseket mérő indikátorcsoportjaként határoztuk meg a fentiekben bemutatott szakirodalom 
alapján.

\subsubsection{A szubjektív életminőség operacionalizálása és mérése}

Az alapkoncepciónk az volt, hogy mindhárom fó dimenziót egy-egy kérdéssel operacionalizáljuk a kutatásunkban, amely kérdések nem általános értelemben fejezik ki az adott dimenziót, hanem jelentős mértékben megragadják annak jelentéstartalmát, úgy is fogalmazhatunk, hogy önmagában is multidimenzionálisan adják vissza az adott szükséglettípus jelentését. Ehhez a '93-as allardti modellt vettük alapul. Így a „Having” dimenzó esetében az életszínvonallal való elégedettséget, a „Loving” dimenzónál a beágyazottságot és a támogatottságérzetet, a „Being” dimenzió esetében az önmegvalósítás érzetet. A jóllét érzéseihez kapcsolódóan pedig a korábbi modellhez nyúlunk vissza, és tartós érzelemként a boldogságérzetet, illetve a rövid távú érzések tekintetében a pozitívnegatív érzelmi egyenleget fogjuk operacionalizálni. A 2006-os és 2012-es ESS kérdőívek „Personal and Social well-being” kérdésblokkjai tartalmazták a fö szükségletdimenziókat tartalmilag megfelelően megragadó kérdéseket, azonban az életszínvonallal való elégedettség kérdését a 2012-es kérdőív már nem tartalmazta, csupán az élettel való elégedettségre kérdezett rá.

A szakirodalomban a korábbiakban bemutatott életminőség koncepció (,,topdown approach”) alapján ismert, hogy az embereknek az életükkel való általános elégedettség érzése az, ami meghatározza, hogy mennyire elégedettek az életük egyes területeivel (Andrews\&Withey, 1974). Ugyanakkor az élettel való általános elégedettséget felfoghatjuk úgy is, mint az egyes életterületekkel való elégedettség aggregált mutatóját (Van Praag et al., 2001), amely így az anyagi körülmények értékelését is magában foglalja (természetesen az egyes területekkel való elégedettségek egymásra is hatással vannak). Allardt korai modelljében a Having dimenziót az életszínvonallal konceptualizálta, és empirikus vizsgálatában a jövedelemmel és a lakósürűséggel mérte, azonban későbbi modelljében a dimenzió szubjektív oldalát az életszínvonallal való elégedettség helyett tágabb fogalom mentén, az életkörülményekkel való elégedettség alapján határozta meg (Allardt, 1973, 1993). A szakirodalom és a tágabb megközelítés alapján kutatásunkban így az élettel való elégedettséget az életkörülményekkel való elégedettség közvetett indikátorának tekintjük, és mindkét évben ezt a mutatót alkalmazzuk. 
A 2006-os évben háromféle megfogalmazásban került lekérdezésre az élettel való elégedettség: mennyire elégedett élete eddigi alakulásával (a múltra vonatkozóan), mennyire elégedett jelenlegi életével, és a harmadik kérdéstípus egy korai, a korábbi fejezetben említett Chekola elméletére vezethető vissza, amikor még nem tettek distinkciót a szubjektív jólét affektív és kognitív oldalai között: „Mindent összevetve nagyjából úgy élek, ahogy szeretnék.” (ez utóbbinál 5-fokú Likert skálán vették fel a válaszokat a „teljesen egyetért”-től az „egyáltalán nem ért egyet” kategóriáig). Az indikátorok közötti összefüggések előzetes ellenőrzése körében így a 2006-os mintán több vizsgálatra nyílt mód, összevetve az élettel való elégedettség és az életszínvonallal, vagy a munkával való elégedettség közötti együtt-járások erősségét. Az élete eddigi alakulásával, illetve jelenlegi életével való elégedettség és az életszínvonallal való elégedettség erős pozitív kapcsolatot mutatott (Pearson-féle korrelációs együttható értékei rendre: 0,$665 ; 0,552)$, míg az aktív népesség körében az élete eddigi alakulásával és a munkával való elégedettség között pedig 0,453 volt a korreláció. Több életterülettel való elégedettség összehasonlítására az ESS minta nem adott lehetőséget. Összességében tehát, az elméleti megközelítések és az együttjárások ellenőrzése alapján az élettel való elégedettséget elfogadtuk az életkörülményekkel való elégedettség proxy változójának. Így a kutatásunkban kifejlesztett szubjektív életminőség többdimenziós indikátora az élettel való elégedettségérzetet, a támogatottságérzetet, az önmegvalósítás-érzetet, a boldogságérzet és a pozitív-negatív érzések egyenlegét fogja át, melyeket az alábbi kérdésekkel operacionalizáltunk (az érzelmi balansz kérdéseire lejjebb térünk ki):

(1) Mindent összevetve mennyire elégedett mostani életével?

(2) Vannak olyan emberek az életemben, akik igazán törődnek velem. (2006) Milyen mértékben kap segítséget és támogatást az Önhöz közelállóktól, amikor szüksége van rá? (2012)

(3) Úgy érzem, amivel foglalkozom az életemben az értékes és megéri a fáradtságot.

(4) Mindent egybevetve mennyire érzi magát boldognak?

Az (3) számú kérdést 2012-ben az angol nyelvü kérdőívben változatlanul, a magyar kérdőívben részben eltérő megfogalmazással tették fel: „Úgy érzem, amivel 
foglalkozom az életemben az értékes és hasznos mások számára.” Az eltérés nem olyan lényeges, mely a kérdésnek alapvetően más jelentéstartalmat adna, így a kérdés ebben a formában szerepel a 2012-es szubjektív életminőség indikátorban. A (1) és (4) számú kérdések esetében a megkérdezettek 11 fokú skálán értékelhették életüket a „Teljesen elégedetlen” illetve „Nagyon boldogtalan” („,0”) kategóriától a „Teljesen elégedett” illetve „Nagyon boldog” („10-es”) kategóriáig. A (2)/2006 és (3) számú kérdések esetében a válaszokat 5 fokú Likert-skálán vették fel, melyek az 1-es „Teljesen egyetért” értéktől az 5-ös „Egyáltalán nem ért egyet” értékig terjedtek. Ezen kérdések irányát megfordítottuk, így amikor a válaszok magasabb skálaértéket mértek, az azt jelentette, hogy a válaszadó magasabb szinten tudja realizálni a szociális- (loving) és a személyes fejlődés (being) szükségleteit. A (2)/2012 kérdést hétfokú skálán mérték az „Egyáltalán nem” (0) értéktől a „Teljes mértékben” (6) kategóriáig terjedően. Itt térünk tehát vissza a Loving dimenzióra, melynek realizációját mérő skála a fentiekben bemutatottak alapján tehát 2006-ban és 2012ben eltérő megfogalmazásban és skálán került felvételre. Azonban a két kérdés tartalmilag a vizsgált jelenséget (támogatottságérzet) ragadja meg, melyet az is bizonyít, hogy más vizsgálatokban az ESS adatok komparatív elemzése során szintén megfeleltették egymásnak e két változót, jóllehet abban a kutatásban egy más elméleti keretbe ágyazottan, a bevezetőben is említett, többdimenziós indikátort dolgoztak ki a kutatók (Harrison et al., 2016).

Az allardti modell, ahogyan fentebb említettük, számos átfogó, tartósan fennálló percepció (pl. boldogságérzet) mellett több olyan kérdést is tartalmazott, melyek rövid távú, átmeneti érzéseket is mértek (pl.: magány, nyugtalanság, különböző frusztrációk). Itt szeretnénk hangsúlyozni, hogy a jóllét tartósan fennálló és időszakos érzéseit egy-egy önálló mutatóként kívánjuk operacionalizálni (KimPrieto et al., 2005). Tehát az átfogó boldogságérzet láttuk, hogy az allardti modellben a „Loving” dimenzióban helyezkedett el, onnan kiemelve a továbbiakban önálló mutatóként képezi részét a többdimenziós szubjektív életminőség indikátorunknak. Továbbá a rövid távú érzések gyakoriságát egy további önálló mutató kialakításával fogjuk bevonni a kompozit mérőeszközünkbe. A kutatásban ezen érzések társadalmi vagy egyéni hátterét nem kívánjuk eltérő változók útján feltárni, azonban a pozitív és negatív tartalmú rövid távú, időszakos érzések előfordulását, mint érzelmi egyenleget kívánjuk bevonni. Ennek elsődleges oka, hogy a válság éveiben 
bekövetkezett, a dolgozat bevezetőjében felsorolt egyéni életvitelbeli, életmódbeli változások (úgy érezte, hogy az élete „,beragadt”, nem tud tovább lépni; anyagi problémáinak megoldása érdekében a barátaitól kért kölcsön, amely szégyenérzettel járt; személyes értéktárgyait értékesítette; nem tudott annyit költeni szabadidős tevékenységre, az egészségére, mint korábban; nem tud tervezni a jövőre, stb.) folyamatosan, átmeneti frusztrációkat, aggodalmakat, stresszt váltottak ki az egyénekben, melyek különböző tartalmú érzésekben, eltérő gyakorisággal csapódtak le a mindennapi életük során. A szakirodalom szerint azonban a rövid távú érzelmi állapotok mérésekor elegendő néhány általános, pozitív és negatív tartalmú állapotot kifejező érzést mérni, a helyett, hogy nagyszámú, speciális érzéseket megragadó mutatókkal dolgoznánk, tekintettel arra, hogy a speciális érzéseket a megkérdezettek ritkábban és kisebb előfordulási gyakorisággal élik meg (Diener et al., 2010). Ezért a koncepciónk az alábbi 2-2 pozitív és negatív, általános, egymás ellentétpárjaként állítható érzelmi állapotok bekövetkezésének gyakoriságát mérő változókat tartalmazza:

(5) Múlt héten milyen gyakran élvezte az életet?

(6) Múlt héten milyen gyakran volt levert?

(7) Múlt héten milyen gyakran volt nyugodt, békés?

(8) Múlt héten milyen gyakran volt nyugtalan?

A kérdésekre 4 fokú skálán adhattak választ a megkérdezettek, az alábbiak szerint: 1=,Soha vagy szinte soha”, 2=”Néha”, 3=”Többnyire”, 4=,Mindig vagy majdnem mindig”. A kérdésekre adott válaszok megoszlásait a 4. táblázata foglalja össze. Az ellentétes töltetü emóciókat a szakirodalomban leggyakrabban vagy egy önálló pozitív és egy önálló negatív érzéseket mérő skála kialakítása segítségével mérik, vagy egy érzelmi balanszot mérő mutatót hoznak létre például a korai Bradburnskála módszere alapján (Bradburn, 1969, idézi: Diener, 1994).

$\mathrm{Az}$ önálló mutatók kialakításához alacsony volt a kérdőívben szereplő felhasználható pozitív tartalmú itemek száma, ezért az utóbbi megoldást választottuk. Ennek megfelelően a pozitív érzésekből kivontuk az ellentétes töltetű negatív érzéseket, és a pontértékek összegzésével egy egyszerü szummatív skálát konstruáltunk (5. táblázat). 
4. táblázat: A rövid távú pozitív-negatív érzéseket mérő változók megoszlásai a teljes mintában* (\%), 2006, 2012

\begin{tabular}{|c|c|c|c|c|c|}
\hline $\begin{array}{c}\text { Múlt héten milyen } \\
\text { gyakran élvezte az } \\
\text { életet? }\end{array}$ & $\begin{array}{c}\text { Soha vagy } \\
\text { szinte soha } \\
(\mathbf{1})\end{array}$ & $\begin{array}{c}\text { Néha } \\
\mathbf{( 2 )}\end{array}$ & $\begin{array}{c}\text { Többnyire } \\
\mathbf{( 3 )}\end{array}$ & $\begin{array}{c}\text { Mindig vagy } \\
\text { majdnem } \\
\text { mindig } \\
\mathbf{( 4 )}\end{array}$ & $\mathbf{N}$ \\
\hline $\mathbf{2 0 0 6}$ & 12,0 & 27,7 & 45,0 & 15,3 & 1487 \\
\hline $\mathbf{2 0 1 2}$ & 10,5 & 35,4 & 40,5 & 13,7 & 1977 \\
\hline $\begin{array}{c}\text { Múlt héten milyen } \\
\text { gyakran érezte magát } \\
\text { levertnek? }\end{array}$ & & & & & \\
\hline $\mathbf{2 0 0 6}$ & 22,7 & 51,4 & 19,5 & 6,4 & 1511 \\
\hline $\mathbf{2 0 1 2}$ & 30,5 & 50,2 & 15,1 & 4,2 & 2005 \\
\hline $\begin{array}{c}\text { Múlt héten milyen } \\
\text { gyakran volt nyugodt és } \\
\text { békés? }\end{array}$ & & & & & 190 \\
\hline $\mathbf{2 0 0 6}$ & 3,8 & 27,2 & 51,3 & 17,7 & 1507 \\
\hline $\mathbf{2 0 1 2}$ & 4,5 & 29,5 & 52,3 & 13,7 & 2005 \\
\hline $\begin{array}{c}\text { Múlt héten milyen } \\
\text { gyakran volt nyugtalan? }\end{array}$ & 29,2 & 50,3 & 15,5 & 5,0 & 1510 \\
\hline $\mathbf{2 0 0 6}$ & 28,7 & 53,4 & 13,9 & 4,0 & 1990 \\
\hline $\mathbf{2 0 1 2}$ & & & & & \\
\hline
\end{tabular}

*Az érvényes válaszokon belül.

5. táblázat: A rövid tartamú pozitív-negatív érzések egyenlegét mérő skála, 2006, 2012 [átlag (szórás)]

\begin{tabular}{|c|c|c|c|}
\hline \multicolumn{1}{|c|}{ Változó } & Változó értékei & $\mathbf{2 0 0 6} *$ & $\mathbf{2 0 1 2} * *$ \\
\hline Pozitív-Negatív Érzések & $\begin{array}{l}\mathbf{- 6 =} \text { negatív balansz } \\
+\mathbf{6}=\text { pozitív balansz } \\
\text { Balansza }\end{array}$ & $\begin{array}{c}1,402 \\
(2,459)\end{array}$ & $\mathrm{N}=1963$ \\
\cline { 2 - 4 } & & $\begin{array}{c}1,462 \\
(2,333)\end{array}$ \\
\hline
\end{tabular}

Az attitűdskála pozitív értékei pozitív érzelmi egyenleget (több pozitív érzést tapasztalt meg, mint negatívat), negatív értékei negatív egyenleget jelentenek. Mindkettő évben a megbízhatósági mutató értéke magas, tehát a skálák megbízhatósága elfogadható. A szubjektív életminőség operacionalizációjánál felsorolt (1-4) kérdések és az érzelmi balansz skála erős összefüggést mutattak (Lásd a függelék F.3.2. sz. táblázatait.), ezért főkomponens elemzéssel egy összetett mutatót készítettünk, mely a megfigyelt változók lineáris kombinációjaként a 
szubjektív életminőséget, mint látens változót hozta létre (6. táblázat). Ahogyan már említettük, önálló mintákon végeztük el a főkomponens-elemzést, tekintettel arra, hogy a Loving dimenziót 2012-ben eltérő megfogalmazásban, eltérő terjedelmü skálán vették fel, mint 2006-ban. Továbbá azért is, mert a kutatás számára kialakított társadalmi nagycsoportok szubjektív életminőségét mindkét időszakban első lépésben, feltáró jelleggel, önállóan kívántuk elemezni.

6. táblázat: A Szubjektív Életminőség Index statisztikái, 2006, 2012 (fökomponenselemzés)

\begin{tabular}{|c|c|c|c|}
\hline & \multicolumn{2}{|c|}{$\begin{array}{c}\text { Korreláció a szubjektív életminőséget mérő } \\
\text { főkomponenssel }\end{array}$} \\
\hline & & 2006* & $2012 * *$ \\
\hline \multicolumn{2}{|c|}{ „Having” } & 0,783 & 0,783 \\
\hline \multicolumn{2}{|c|}{ „Loving” } & 0,595 & 0,635 \\
\hline \multicolumn{2}{|c|}{ „Being” } & 0,633 & 0,566 \\
\hline \multirow{2}{*}{$\begin{array}{l}\text { „Feelings of well- } \\
\text { being” }\end{array}$} & Boldogság & 0,822 & 0,843 \\
\hline & Pozitív-negatív balansz & 0,715 & 0,759 \\
\hline \multicolumn{2}{|c|}{ Sajátérték } & 2,555 & 2,624 \\
\hline \multicolumn{2}{|c|}{ Négyzetes faktorsúlyok összege } & 51,107 & 52,487 \\
\hline
\end{tabular}

*KMO=0,775; Chi-Sq. Sign.=,000; **KMO=0,766; Chi-Sq. Sign. $=, 000$

5. ábra: A Szubjektív Életminőség Index megoszlásai (2006, 2012)

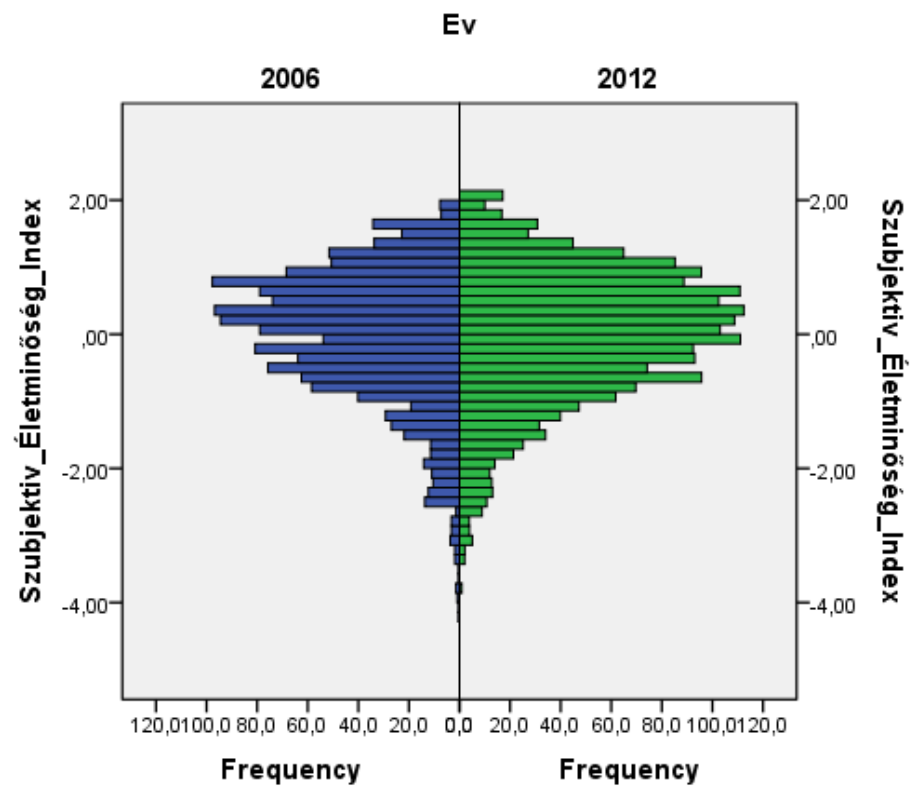


Az elemzés eredménye tehát egy standardizált ( 0 átlagú; 1 szórású) látens, ún. faktorszkór-változó, melynek megoszlását az 5. ábra mutatja mindkét év vonatkozásában. A táblázatban láthatjuk, hogy mindkét évben csak egy db 1-nél magasabb sajátértékkel rendelkező ilyen faktor-változó létezik, mely a bevont változók szórásnégyzetének lehető legnagyobb részét magyarázza meg (ez esetben nem túlzottan magas, 51 és 52\%). A változó pozitív (magasabb) faktorszkór értékei azt jelentik, hogy az egyén magasabb szinten realizálja az alapvető szükségleteit, így a mutatón elért magasabb pontok kedvezőbb szubjektív életminőséget fejeznek ki, míg az alacsonyabb negatív értékek alacsonyabb realizációs szintet mérnek. A szubjektív életminőség kompozit indexét a mutató érvényességének ellenőrzése céljából összehasonlítottuk a korábbi fejezetben bemutatott dieneri szubjektív jóllét összetett indikátorával, mely hazai és nemzetközi kutatásokban használt, megbízhatósági és érvényességi kritériumok szerint többszörösen tesztelt, sztenderd, egyéni jóllétet mérő indikátornak tekinthető, és amelyet a rendelkezésre álló adatok alapján le tudtunk képezni mindkét évben. Magyarországon, egy korábbi kutatásban kifejlesztett multidimenzionális szubjektív életminőséget mérő mérőeszköztől (Szabó, 2003) eltekintve, nem találkoztunk olyan szubjektív életminőség indikátorral, amelyet az allardti koncepció, vagy más szubjektív életminőség koncepció mentén alakítottak volna ki, így a dieneri indikátor kettő típusán és Chekola mutatóján kívül más, hasonló skálával nem tudtuk összevetni az általunk létrehozott mérőeszközt. Az említett szerző (Szabó, 2003) által kifejlesztett indikátor az adataink alapján nem volt rekonstruálható. ${ }^{9}$ Chekola indikátora azonban azért is figyelmet érdemel, mert az egyéni jóllét vizsgálatának korai időszakában a kutatók nem tettek különbséget a jóllét affektív és kognitív oldalai között, azonban több olyan egyitemü skálát alakítottak ki, melyek együttesen ragadták meg az attitüd érzelmi és racionális oldalait. Chekola a boldogságról írt disszertációjában fejlesztette ki mutatóját, melyet a magunk részéről a szakirodalomban fellelhető olyan mutatónak tartottunk, amelyik egyitemü mérőeszközként a leginkább alkalmas lehet a két oldal együttes kifejezésére, ahogyan a szerző fogalmazott: „az egyén céljainak és vágyainak harmónikus egysége" (Chekola, 1975, idézi: Diener, 1984:543). A szubjektív életminőség mutatója és a többi indikátor közötti kapcsolatot a 6. sz. táblázat foglalja

9 A többdimenziós méröeszközök témaköréhez kapcsolódóan az Élettel való elégedettség Index indikátorát mutatja be külföldi szakirodalom alapján az F.2. sz. függelék. 
össze. A szubjektív jóllét (subjective well-being=SWB) indikátor a korábban bemutatott dieneri összetett szubjektív jólléti modell mutatóinak bevonásával került kialakításra fökomponens elemzéssel. Az SWB multidim. indikátort szintén fökomponens-elemzéssel hoztuk létre, itt azonban az élettel való elégedettséget is kettő (múltbeli életre és a jelenlegire vonatkozó értékelés), és a boldogságot is kettő (a hagyományos, és Chekola definíciója értelmében mért) változókkal, illetve a pozitív-negatív balansz skálájával konstruáltuk. (A statisztikák a 7. táblázat megjegyzésénél olvashatóak. A korrelációs együtthatók értékeit a képzett indikátorok változó-struktúrájával együttesen kell figyelembe venni.)

7. táblázat: A Szubjektív Életminőség Index és a dieneri szubjektív életminőséget mérő mutatók, illetve Chekola indikátorának kapcsolata, 2006, 2012 (korrelációs együtthatók)

\begin{tabular}{|c|c|c|c|}
\hline & Chekola & SWB $^{10}$ & SWB multidim. \\
\hline $\begin{array}{c}\text { Szubjektív Életminőség Index } \\
2006\end{array}$ & $0,565^{* *}$ & $0,869^{* *}$ & $0,899^{* *}$ \\
\hline $\begin{array}{c}\text { Szubjektív Életminőség Index } \\
2012\end{array}$ & - & $0,947^{* *}$ & - \\
\hline
\end{tabular}

Megjegyzés: Chekola indikátor: „Mindent összevetve nagyjából úgy élek, ahogy szeretnék.” (5-fokú Likert skálán mérték, a teljesen egyetért-től az egyáltalán nem ért egyet válaszkategóriáig terjedően.) $\mathrm{SWB}_{2006}=$ elégedettség mostani élettel; boldogság; pozitív-negatív balansz (KMO: 0,652; Chi-Square: 998,633; df=3; Sign.: ,000; 1 db faktor, sajátértéke: 1,963; magyarázott variancia: 65,447).

$\mathrm{SWB}_{2012}=$ elégedettség mostani élettel; boldogság; pozitív-negatív balansz (KMO: 0,667; Chi-Square: 1895,183; df=3; Sign.: ,000; 1 db faktor, sajátértéke: 2,119; magyarázott variancia: 70,628).

SWB_m= elégedettség eddigi életével; elégedettség mostani életével; mindent összevetve nagyjából úgy élek, ahogy szeretnék; boldogság; pozitív-negatív balansz. (Főkomponens-elemzés statisztikái: KMO: 0,845; Chi-Square: 2482,298; df=10, Sign.:,000; $1 \mathrm{db}$ faktor, sajátértéke: 2,972; magyarázott variancia: 59,435).

Szignifikancia: ${ }^{*} \mathrm{p}<0,05,{ }^{* *} \mathrm{p}<0,01$

Az eredmények alapján látható, hogy a jelen kutatás számára kidolgozott multidimenzionális Szubjektív Életminőség Index érvényessége megfelelő, szorosan összefügg más kutatók által definiált szubjektív jóllét mérésére kialakított mutatókkal. Azonban, tekintettel arra, hogy az összevont keresztmetszeti adatokon a két év összvetésében az idő-dummy változója alapján várt eltérésekkel kívánjuk tesztelni a lakosság szubjektív életminőségének változását a válságot követően, ezért az elemzésekhez egy ugyanazon változók felhasználásval készült szummatív szubjektív életminőség skálát is kialakítottunk. Itt a 2012-es Loving dimenzió

10 A szubjektív jóllét (SWB, SWB multidim.) főkomponenseit a skála-összefüggések vizsgálata céljából hoztuk létre, ezeket az empirikus elemzésem során nem használtuk. 
hétfokú támogatottságérzetet mérő kérdését 5 fokúra kódoltuk a szélső kategóriák össszevonásával. A szummatív életminőség skála 0 és 36 között vesz fel értékeket (átlag: 21,22; szórás: $6.79(\mathrm{~N}=3356)$, és a megbízhatósági Cronbach Alpha mutató értékei: 2006: 0,768; 2012: 0,781, melyek elfogadhatóak. ${ }^{11}$ A skála megoszlását a 6. ábra mutatja be.

6. ábra: A szummatív Szubjektív Életminőség Skála megoszlásai (2006, 2012)

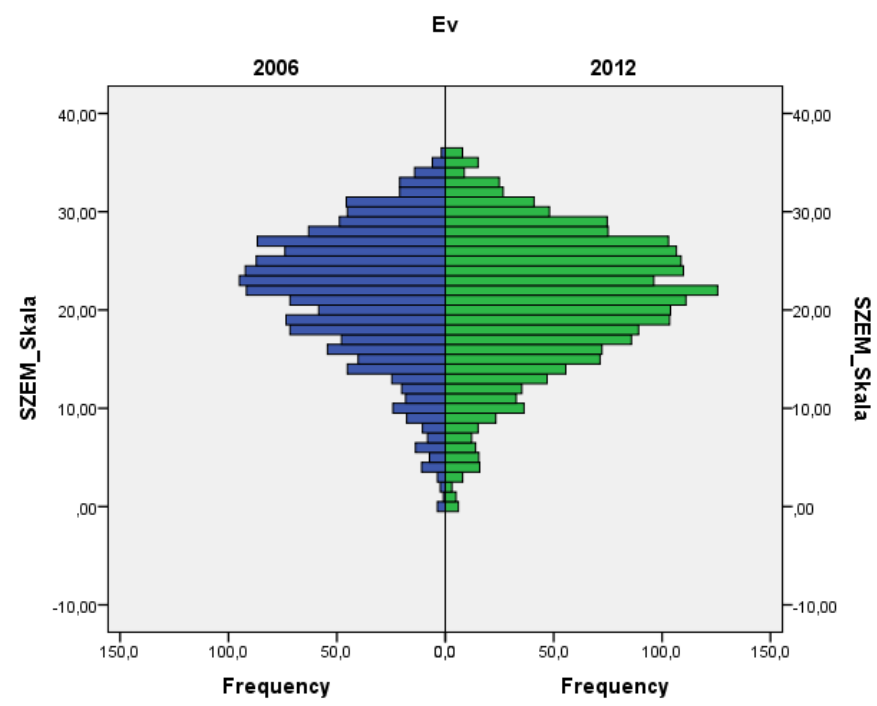

\subsubsection{A magyarázó változók operacionalizálása}

a.) Anómia és elidegenedésérzet

A válságok általános következménye a társadalomban érzékelhető kisebb vagy nagyobb fokú egyéni és társadalmi szintű anómia, a normaszegés elfogadottságának, az elidegenedésérzetnek a növekvő gyakorisága. A hipotézisünk teszteléséhez magyarázó változóként kialakítottuk az egyéni anómia- és elidegenedésérzet mértékét mérő skálát. A skála kidolgozásához Srole, Seeman és Andorka koncepcióit vettük alapul. Az 1960-as és '70-es években kidolgozott korai teóriák kiindulópontja a durkheimi anómia-elmélet, és a marxi elidegenedés-elmélet

11 A szummatív skála esetében a két évre önállóan készítettük el az összetett indikátort, tekintettel arra, hogy a Loving dimenzió kérdése 2012-ben eltérő megfogalmazásban került lekérdezésre. Ugyanakkor felmerült az összevont adatoknál a súlyozás kérdése, amely esetben a témavezetővel történt megbeszéléskor, tájékoztatása alapján, a korábbi holland kutatócsoporttal végzett vizsgálatukban számos pro és kontra érvet hoztak fel a kutatók a több év összekapcsolt adatainak elemzésekor arra vonatkozóan, hogy az adatállományokat egyféle, vagy minden állományt a saját keresztmetszeti súlyváltozójával súlyozzák. Elmondása alapján, végső soron alkalmazható mindkét módszer, megszorításokkal. 
volt. Durkheim a társadalom azon állapotát nevezte anómiának, amikor a társadalmat szabályozó értékek és normák veszítenek erejükből és nem az erkölcsi és jogi elveknek megfelelően működnek (Durkheim, 1986). A szakirodalmat áttekintve azt láttuk, hogy az egyes anómia és elidegenedés fogalmakat a társadalomtudósok egymás definícióit, vagy annak egyes részeit átvéve, illetve saját kutatási eredményeik alapján újabb tartalmi elemekkel kiegészítve alkották meg (Srole, 1956, idézi Andorka: 1996; Seeman, 1959). Seeman például bevonta elidegenedés definíciójába az anómia koncepció normátlanság dimenzióját. Srole úgy gondolta, hogy az anómia és az elidegenedés nem egyértelműen összetartozó fogalmak, ezzel együtt anómia skálájában ő is szerepeltette egyéb itemek mellett az elidegenedés seemani modelljének kettő elemét: „értelmetlenség, elmagányosodás”. A kutatásunkban e kettő dimenziót, illetve Srole anómia skálájának öt eleméből a következő kettő itemet vettük figyelembe: „az egyén hiábavalónak, haszontalannak érzi magát; nem várható segítség az embertársaktól” (Andorka, 1996:134-143). Az öt általunk kiválasztott item közül kettő szerepel az Andorka által kidolgozott anómia koncepcióban, melyet maga a szerző és munkatársai is több empirikus vizsgálat során alkalmaztak (Spéder et al., 1998; Spéder-Kapitány, 2002). Az anómiát és elidegenedésérzetet mérő indikátort kutatásunkban az alábbi kérdésekkel operacionalizáltuk:

(1) Legtöbbször úgy érzem, hogy van értelme annak, amit csinálok. (inverze: értelmetlenségérzet)

(2) Múlt héten milyen gyakran érezte magányosnak magát? (elmagányosodás)

(3) Mennyire érzi, hogy segítőkészek az emberek a közvetlen környezetében? (inverze: elszigeteltségérzet)

(4) A mindennapokban ritkán adódik lehetőségem arra, hogy megmutassam, mire is vagyok képes. (haszontalanságérzet)

A változók jelentéstartalmát a kérdések után zárójelben jelöltük. Az (1) és (3) számú kérdésekre a megkérdezettek 5-fokú Likert-skálán adhattak választ, melyek az 1-es „Teljesen egyetért” értéktől az 5-ös „Egyáltalán nem ért egyet” értékig terjedtek. Jóllehet e két kérdés pozitív tartalommal került megfogalmazásra, azonban a kérdések inverze a megragadni kívánt jelenség, jelentéstartalom mértékéről ad 
információt. Továbbá az (1) számú kérdés inverze: az „értelmetlenségérzet” Srole (1956) korai anómia definíciójának, illetve Seeman (1959) elidegenedés koncepciójának is az eleme, ahogyan Andorka elidegenedés definíciójának is kulcseleme volt (Andorka, 1996:135), így a pozitív megfogalmazás ellenére ezt a változót alkalmaztuk. ${ }^{12}$ Illetve a (3) sz. kérdésnél a közvetlen környezet a szomszédságot, és nem a szubjektív életminőség skála loving dimenziójának operacionalizálásakor megfogalmazottak szerinti közvetlen ismerősöket jelenti, akik ott viszont a családi, baráti kapcsolatokat, és így a támogatottságérzetet mérik. ( $\mathrm{E}$ mellett természetesen a dolgozat végén feltüntettük a kérdés pozitív megfogalmazását, mint az egyik gyengeségét a kutatásnak.) A (2) számú kérdések esetében a válaszokat 4-fokú skálán rögzítették az 1=,Soha vagy szinte soha”, 2="Néha”, 3=”Többnyire”, 4=,Mindig vagy majdnem mindig” válaszkategóriák segítségével. A (4) számú kérdés megválaszolásakor a válaszokat a „,” (,egyáltalán nem”) értékkategóriától a 6-os („nagyon”) kategóriáig terjedően, hétfokú skálán vették fel. A fenti változókon elért pontszámok összeadásával egy egyszerü szummatív skálát hoztunk létre, mely értékeit 4-21 közötti tartományban veszi fel. $\mathrm{Az}$ indikátor alacsony értékei kisebb fokú, míg a magasabb értékei nagyobb fokú egyéni anómia- és elidegenedésérzetet jelentenek. A skála megbízhatóságát kifejező Cronbach Alpha statisztika értéke 2006-ban 0,74; 2012-ben 0,73 amely elfogadható (Babbie, 2007: 156-167). (A statisztikákat lásd a 8-9. táblázatokban, a 7. ábrán és a F. 5. sz. Függelékben.)

8. táblázat: Az anómia és elidegenedés skála és elemeinek statisztikái, 2006

\begin{tabular}{|l|c|c|c|c|c|}
\hline \multicolumn{1}{|c|}{$\mathbf{2 0 0 6}$} & $\mathbf{N}$ & Min. & Max. & Átlag & Szórás \\
\hline Értelemnélküliség & 1509 & 1 & 5 & 2,05 & 0,870 \\
\hline Magányosságérzet & 1505 & 1 & 4 & 1,59 & 0,865 \\
Izoláció & 1503 & 1 & 7 & 4,14 & 1,558 \\
Haszontalanságérzet & 1482 & 1 & 5 & 3,07 & 1,007 \\
\hline $\begin{array}{l}\text { Anómia-elidegenedés } \\
\text { skála* }\end{array}$ & $\mathbf{1 4 5 7}$ & $\mathbf{4}$ & $\mathbf{2 1}$ & $\mathbf{9 , 3 9 8}$ & $\mathbf{2 , 7 4 6}$ \\
\hline
\end{tabular}

*Chr. Alfa=0,734; ANOVA Between Items: F=9317,104; df=4, Sign.=0,000.

12 Ugyanakkor, nem gondoljuk, ahogyan az egyik bíráló kifogásolta, hogy az (1) számú kérdés a szubjektív életminőség being dimenzió operacionalizált (3) sz. kérdésével tartalmi átfedést mutatna, ti. ezen utóbbi az önmegvalósítás fogalmát és egyben az eredeti allardti Being dimenzió tartalmát képezi le, ahogyan meghatározásra is került jelen kutatásban, tehát egy sokkal tágabb fogalmi kört ragad meg, míg ezzel szemben az előbbi (1) számú változó viszont nem. 
9. táblázat: Az anómia és elidegenedés skála és elemeinek statisztikái, 2012

\begin{tabular}{|l|c|c|c|c|c|}
\hline \multicolumn{1}{|c|}{$\mathbf{2 0 1 2}$} & $\mathbf{N}$ & Min. & Max. & Átlag & Szórás \\
\hline Értelemnélküliség & 1994 & 1 & 5 & 2,31 & 0,979 \\
Magányosságérzet & 2000 & 1 & 4 & 1,63 & 0,848 \\
\hline Izoláció & 2010 & 1 & 7 & 4,27 & 1,445 \\
\hline Haszontalanságérzet & 1991 & 1 & 5 & 2,99 & 1,097 \\
\hline $\begin{array}{l}\text { Anómia-elidegenedés } \\
\text { skála* }\end{array}$ & $\mathbf{1 9 6 5}$ & $\mathbf{4}$ & $\mathbf{2 0}$ & $\mathbf{9 , 6 5 9}$ & $\mathbf{2 , 8 1 9}$ \\
\hline
\end{tabular}

*Chr. Alfa=0,743; ANOVA Between Items: F=12972,585; df=4; Sign.=0,000.

7. ábra: Az egyéni anómia- és elidegenedésérzetet mérő skála megoszlásai (2006, 2012)

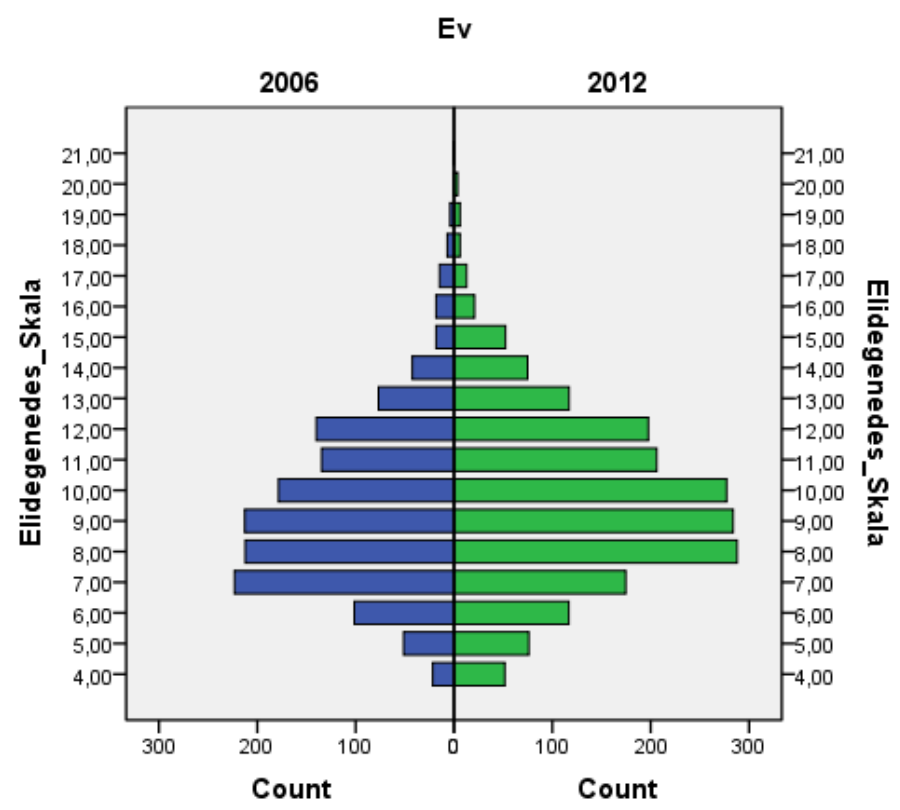

b.) A szubjektív egészség, jövedelmi helyzet és biztonságérzet alapján kialakított társadalmi nagycsoportok polarizációjának hipotézisei vizsgálatához a magyarázó változókat a következő kérdésekkel operacionalizáltuk:

(1) Melyik leírás közelíti meg leginkább az Önök háztartásának jelenlegi jövedelmi helyzetét?

(2) Milyen az Ön általános egészségi állapota?

(3) Milyen biztonságos ezen a környéken sötétedés után egyedül sétálni? 
Az első kérdés esetében a válaszadók azt értékelték, hogy a háztartás rendelkezésére álló jövedelméből hogyan tudnak megélni a háztartás tagjai: kényelmesen megélnek (1), kijönnek (2), vagy nehezen élnek meg (3), esetleg nagyon nehezen élnek meg a jelenlegi jövedelmükből (4). A válaszok egyéni szinten állnak rendelkezésre, jóllehet maga a kérdés a háztartási egységre vonatkozik, amit az eredmények bemutatásakor és értékelésekor kell majd figyelembe venni. Az egészség szubjektív értékelését 5 fokú skálán mérték az adatfelvételek során, a nagyon jó (1), jó (2), kielégítő (3), rossz (4), és nagyon rossz (5) válaszkategóriákkal. A biztonságérzet esetében a megkérdezettek válaszait 4 fokú skálán rögzítették [nagyon biztonságos (1), biztonságos (2), nem biztonságos (3), egyáltalán nem biztonságos (4)]. Az elemzések első lépésében, a kétváltozós statisztikák elkészítéséhez a szubjektív egészség esetében 3 kategóriás változóvá alakítottuk át az eredeti ötkategóriás változót a két szélső kategória összevonásával (jó, kielégítő, rossz). Azonban a többváltozós elemzések feltételeinek ellenőrzése során, az elemzésbe bevonásra kerülő összes magyarázó változónk függetlenségének (vagyis a lehetséges multikollinearitás elkerülésének) ellenőrzésekor látható volt a ,jó” és „kielégítő” szubjektív egészség dummy változói közötti erős kapcsolat $\left(\mathrm{r}^{2}=0,73\right)$, ezért a megbízhatatlan becslések elkerülése érdekében kétértéküre kódoltuk az eredeti változót a következők szerint: szubjektív egészség: 1=jó (nagyon jó + jó + kielégítő), 0=rossz (rossz + nagyon rossz); és hasonlóan jártunk el a biztonságérzet esetében is: 1=van biztonságérzete (nagyon biztonságos + biztonságos), $0=$ nincs biztonságérzete (nem biztonságos + egyáltalán nem biztonságos). A megoszlásokat lásd az F. 4. sz. függelékben.

\section{c.) Társadalmi integráció}

A társadalmi integráció hipotéziséhez kettő, a társadalmi integrációt alapvetően meghatározó indikátort specifikáltunk, mint magyarázó változókat. Az egyik a családi állapot, a másik a munkaerö-piaci jelenlét. A családi állapot tekintetében mindkét évben tartalmazta a kérdöív a törvényes, hivatalos családi státuszt rögzítő kérdéssort, mely alapján a következő kategóriákat lehetett elkülöníteni: házas/törvényes élettársi kapcsolatban él, elvált, özvegy/élettársa meghalt, hajadon/nőtlen. A többváltozós elemzéshez dichotóm indikátort alakítottunk ki aszerint, hogy valaki házasságban/élettársi kapcsolatban él, illetve egyedülálló (megoszlásokat az alapváltozóra és az összevont mutatóra 
vonatkozóan az F. 5. sz. Függelék mutatja). A kérdezett munkaerőpiaci jelenlétét a 2006-os kérdőív a hagyományos „Mi a jelenlegi foglalkozása?” kérdés, illetve az elmúlt hét jellemző tevékenysége alapján rögzítette („A következők közül melyikkel jellemezhető az, amit Ön az elmúlt 7 napban csinált?”). Azonban a 2012-es kérdőív kizárólag az utóbbi kérdést tartalmazta, ezért ezt a kérdést választottuk kutatásunkban a munkaerő-piaci jelenlét operacionalizációjához. Az elemzéshez dichotóm változót hoztunk létre: $1=$ jelen van a munkaerő-piacon, (elmúlt héten dolgozott), illetve $0=$ nincs jelen a munkaerö-piacon (diák, munkanélküli, nyugdíjas, tartós beteg vagy rokkant, háztartásbeli, egyéb státuszban van). A kérdéseket és a képzett változók megoszlásait az F. 6. sz Függelék tartalmazza, mindkét kérdéssel kapcsolatosan további, a kódolásra vonatkozó információkkal együtt.

d.) Személyes jellemvonás

A személyes beállítottság hipotézisének vizsgálatához első lépésben egy optimista-pesszimista attitűdöt mérő indexet hoztunk létre (lásd: F. 7. sz. Függelék), melyet az alábbi kérdésekkel operacionalizáltunk:

(1) Optimistán tekintek a jövőre.

(2) Általában elégedett vagyok magammal.

(3) Néha úgy érzem, kész csőd vagyok.

(4) Ha valami rosszul sül el, nehezen találok vissza a régi kerékvágásba.

A négy attitűdkérdést egy irányba (pozitív, emelkedő) forgatva, arra voltunk kíváncsiak, hogy megtalálható-e mögöttük egy olyan látens attitüd, mely az optimista, magabiztos, a nehéz helyzetekkel megbírkózó személyiségvonást képezi le. A négy attitűdváltozó páronkénti korrelációi változóak voltak (közepes vagy gyenge). A mutatót főkomponens-elemzéssel alkottuk meg, mely egy sajátértékü faktort eredményezett, azonban az index gyenge statisztikái miatt úgy döntöttünk, hogy a személyes beállítottságot mégsem a látens változó, hanem - az attitűdkérdések közül koncepciónk szempontjából leglényegesebb kérdéssel -, az optimista vagy pesszimista személyes jellemvonást mérő „Optimistán tekintek a jövőbe" kérdéssel operacionalizáljuk. Az adatokat 5-fokú Likert skálán vették fel, mely az 1-es „Teljesen egyetért” értéktől az 5-ös „Egyáltalán nem ért egyet” válaszkategóriáig terjedtek. A mutató irányát pozitív, emelkedő irányba forgatva, a 
két szélső kategóriát összevonva alakítottuk ki a leíró elemzésekhez az optimista (45), a neutrális (3), és a pesszimista (1-2) attitüdöt mérő indikátorokat (a leíró statisztikákat lásd az F. 7. sz. Függelékben).

$\mathrm{Az}$ elemzésekhez a dichotóm társadalmi nagycsoportokat objektív és szubjektív indikátorok mentén alakítottuk ki, ezért tekintettel arra, hogy a függő változó is szubjektív percepciók kompozit mutatója, felmerülhet az endogenitás kérdése. Jóllehet a függő és független változók korrelációs mátrixa egy esetben mutatott magasabb $r^{2}$ értéket, a szubjektív életminőség és az egyéni anómia- és elidegenedés skála között, azonban ez nem haladta meg a szakirodalomban felső kritikus határként jeleztt 0,7-es mértéket. A kutatási előzményeknél beszámoltunk azokról az elemzésekről, melyek nem csupán az élettel való elégedettség és a boldogságérzet különbözőségére hívták fel a figyelmet (Luhmann et al., 2012), de eltérő attitűdöket és érzéseket mérő, jelen kutatásban is alkalmazott szubjektív indikátoroknak (pl. optimizmus vs. rövid távú érzéseket mérő skálák) a különbözőségére is (Lucas et al., 1996), illetve a közöttük fennálló gyenge korrelációkra (Diener, 1994:116-118). Tehát ezen empirikus eredmények alapján nem tartottuk az endogenitás problémát jelentős súlyúnak, továbbá nem gondoltuk kutatásunkat, a szakirodalom alapján e területen kidolgozott szubejktív változókkal és alkalmazott módszerekkel elkészült kutatásoktól jelentősen eltérőnek. Továbbá itt szeretnénk jelezni azt a tényt is, hogy az eredményeket prezentáló fejezetben bemutatott regressziós becslő modellek magas magyarázott variancia értékkel rendelkeztek. Azonban ezek a magas determinációs együttható érték hasonló szubjektív magyarázó modellekhez képest nem meglepőek, ahogy láthattuk a lakókörnyék biztonságával kapcsolatos vizsgálatban, mely során az átfogó életminőséggel való elégedettségre felírt becslés 59\%-os magyarázott varianciát mutatott. Jóllehet azokban a kutatásokban, amelyek célja az előrejelezés, fontos a becslés pontossága, azonban esetünkben nem célunk az előrejelzés, csupán elméleti feltételezéseket tesztelünk, így a determinációs együttható mértéke lényegtelen számunkra (Moksony, 2006:94)- Ezeket a statisztikákat csupán tájékoztató jelleggel közöljük, jóllehet ma már tudományos publikációkban is láttuk, hogy nem közlik azokat (Hank-Wagner, 2013). Ugyanakkor természetesen attitűdök vizsgálatáról lévén szó, a fentebb részletezettek miatt a kutatás eredményeit megszorításokkal szükséges kezelni. 


\subsubsection{A kontrollváltozók specifikálása}

A válság hatását vizsgáló többváltozós elemzésekbe kontrollváltozókat is bevontunk a társadalmi-demográfiai különbségekből adódó eltérések kontrollálása érdekében. Ezek: a nem, az életkor, a településtípus, az iskolai végzettség, illetve az egy före jutó havi nettó háztartási jövedelem változója. Tettük ezt azért, mert a hipotézistesztek szignifikáns eredményei akkor igazolják a hipotézisünkben megfogalmazott állításokat, ha az összefüggés a strukturális hatások kiszürését követően is szignifikáns marad.

A nem változójában a nőket 0 -ra kódoltuk. Az életkort a megkérdezettek születési éve alapján rögzítették, amelyet 6 kategóriás változóvá alakítva az alábbi életkori korcsoportokat hoztuk létre: 30 évtől fiatalabbak, 30-39 évesek, 40-49 évesek, 50-59 évesek, 60-69 évesek, és 70 évesek és idősebbek. A kutatási előzmények között idézett empirikus tanulmányok, és saját korábbi elemzéseink is rámutattak arra, hogy az életkor folytonos változója nem lineáris, hanem U alakú kapcsolatot mutat a szubjektív jólléttel (Blanchflower-Oswald, 2011; Clench-Aas\&Holte, 2017), így az életkori korcsoportokat egy referencia kategória kihagyásával, dichotóm (dummy) változóként szerepeltettük az elemzésben.

A településtípus adatait a kérdőívben az alábbiak szerint rögzítették: 1 . nagyváros, 2. nagyváros elővárosa, 3. város vagy kisváros, 4. falu vagy község, 5. tanya. Az ötkategóriás változót 3 kategóriás mutatóvá alakítottuk (1=nagyváros és elővárosa, 2=város, 3=falu-község-tanya), melyet szintén dummy változókként vontunk be egy kategória kihagyásával.

Az iskolai végzettség esetében a 2006-os magyar kérdőív a következő kategóriákat tartalmazta 1-től 15-ig terjedően: nem járt iskolába (1), 1-4 osztály elemi/általános iskola vagy azzal egyenértékű (2); 5-7 osztály általános iskola vagy azzal egyenértékü (3); befejezett általános iskola vagy azzal egyenértékü (4); szakmunkásképző, szakiskola (5); befejezetlen középiskola (6); érettségi, befejezett középiskola vagy azzal egyenértékű (7); érettségire épülő felsőfokra nem akkreditált szakképzés, középfokú technikum (8); felsőfokra akkreditált szakképzés, felsőfokú technikum (9); befejezetlen felsőfokú tanintézet (főiskola vagy egyetem) (10); főiskolai diploma (11); egyetemi diploma (12); posztgraduális végzettség (13); felsőfokú végzettség, tudományos fokozattal (14); 
egyéb, éspedig (15). (Az adatállomány az egyéb (15) kategóriára vonatkozóan nem tartalmazott adatokat.) Az iskolai végzettség adatai az alábbiak szerint kerültek összevonásra egy négykategóriás iskolai végzettség változóba: alapfokú vagy alacsonyabb iskolai végzettség (1-3,4,6), szakmunkás/szakiskola (5), érettségi (7,8,10), felsőfokú (9,11-14). A 2012-es kérdőív minimális eltéréssel ugyanezen iskolai végzettségek szerinti kategóriákat használta (eltérés: az 1. és 2. kategóriákat egybevontan fogalmazta meg, az egyéb kategóriát pedig 98-as kódszámra rögzítették), így a fentiekhez hasonló négykategóriás változó került itt is kialakításra. A településtípus és az iskolai végzettség változóit szintén dummy változókként, egy referenciakategória kihagyásával szerepeltettük az elemzésekben.

A jövedelem esetében a kérdőív a háztartás összes forrásból származó, havi nettó bevételére kérdezett rá. Az empirikus vizsgálatunk elemzési egysége azonban nem a háztartás, hanem az egyén volt. Így a jövedelemkategóriák átlagát véve, elosztva azokat a háztartásban élők számával, létrehoztuk az egy före jutó nettó havi háztartási jövedelem változóját. (A változó leíró statisztikáit az F. 8. sz. Függelék tartalmazza.) A 2006-os évben a mintában (N=1518) a jövedelem kérdés megválaszolását 189 fő utasította vissza, 75 esetben pedig „nem tudom” válaszkategória került rögzítésre (összesen 264 fö). 2012-ben (N=2014) az előbbi kategória 483 fót, míg az utóbbi 109 főt számlált (összesen 592 fö), mely esetek a többváltozós elemzések során kizárásra kerültek. Arra a kérdésre, hogy a kizárt esetek vajon befolyásolnák-e a többváltozós elemzésben talált összefüggéseket, vagyis a modellben szereplő magyarázó változók hatását, a jövedelemnek az érvényes (valid) és a kizárt eseteit tartalmazó dummy változójának és a magyarázó változóknak a szorzattényezőit, vagyis interakciós tagjait is bevontuk az integrált modellbe, illetve ezen interakciós tagok nélkül is elkészítettük az elemzést. Az interakciós tagok nem voltak szignifikánsak az integrált modellben, vagyis a jövedelemválasz hiánya miatt kizártak esetében nem találtunk eltérő mintázatot az alapmodellben talált összefüggésekhez képest (Moksony, 2006; Sajtos-Mitev, 2007). 


\section{Eredmények}

A Bevezetőben bemutatott makrogazdasági helyzetkép alapján láttuk, hogy Magyarországon a válságot követően 2012-ig csökkent az egy főre jutó GDP, nőtt az infláció, és emelkedett a munkanélküliségi ráta, elsősorban a fiatalok körében. A jövedelem-egyenlőtlenség és a szegénység mutatói szintén arra utaltak, hogy a válság évei alatt a magyar társadalomban nőtt a társadalom két szélső rétegeibe tartozók (elit, depriváltak), és csökkent a középosztályhoz tartozók aránya, egyes kutatói becslések szerint a középosztályi életmód ma már a társadalom „alulról számított 60 százalékának" nehezen érhető el (Tóth, 2016:94). A válságkezelés során hozott gazdaságpolitikai és társadalompolitikai intézkedések a legsérülékenyebb társadalmi csoportokat érintették a legkedvezőtlenebbül (Szivó-Tóth, 2013, 2015).

Kutatásunkban, a gazdasági válság személyes életre gyakorolt kedvezőtlen hatásainak elemzésekor, az egyének percepcióin keresztül mért szubjektív életminőség alakulásának vizsgálata során az egyéni életminőség és meghatározó tényezőinek összefüggését elemeztük, és arra kerestük a választ, hogy az eltérő társadalmi-demográfiai nagycsoportok egymáshoz viszonyított szubjektív életminőségbeli különbségeiben történtek-e elmozdulások a recesszió éveiben, és amennyiben történtek, milyen irányú és mértékü különbségeket mérhetünk. E vizsgálathoz a bevett demográfiai csoportok mellett olyan társadalmi nagycsoportokat hoztunk létre, melyek életminőségbeli különbségeit eddig kevesen vizsgálták. A leíró és a többváltozós elemzések eredményeit jelen fejezetben prezentáljuk.

\subsection{A Szubjektív Életminőség Index elemeinek jellemzői}

Jelen fejezetben a szubjektív életminőséget mérő multidimenzionális mutató elemeinek viselkedését vizsgáljuk meg a fó társadalmi-demográfiai csoportokban (nem, életkor, településtípus, iskolai végzettség, családi állapot, foglalkozási aktivitás) és a szubjektív magyarázó változók mentén (szubjektív jövedelem, szubjektív egészség, biztonságérzet, személyes beállítottság). A leíró elemzés során arra keresük a választ, hogy a szubjektív életminőség általunk kifejlesztett 
indikátorának összetevői alapján miként lehet jellemezni a magyar lakosságot, mely társadalmi-demográfiai csoportok realizálták magasabb szinten az életminőség eltérő szükségletdimenzióit, és ezek a különbségek az egyes csoportok között szignifikánsak-e.

A szubjektív életminőség öt fő dimenziójának átlagait összehasonlítva a két időszakban, az eredmények alapján elmondható, hogy a lakosság élettel való elégedettségérzete enyhe javulást $\left(5,42\right.$ és 5,59), az önmegvalósítás $(3,89 \text { és } 3,72)^{13}$, és a boldogságérzet mérsékelt csökkenést mutatott (6,41 és 6,10), míg az érzelmi balansz átlagai (1,40 és 1,46) alig változtak 2012-re. (A támogatottságérzetet eltérően mérték a két időpontban, az 5 fokú skálán 2006-ban: 4,31 (N=1504); a 7 fokú skálán 2012-ben 4,97 ( $\mathrm{N}=2009)$ volt az átlag.) Az elégedettségérzethez hozzátartozik, hogy hazánkban az átlagos élettel való elégedettség a rendszerváltás idején alacsonyabb volt (1990: 6,03), mint a '80-as években (1982: 6,93), mely a várt társadalmi átalakulás ellenére feltehetően a rendszerváltás időszakát jellemző gazdasági recessziónak, az anómia nagyobb elterjedtségének, és a megörökölt társadalmi normáknak, az ún. panaszkodási kultúrának is köszönhető volt (Spéder et al., 1998; Lengyel-Hegedűs, 2004; Easterlin, 2009).

\section{A „Having” dimenzió realizációja}

A materiális szükségletek szubjektív dimenzióját Allardt (1993) az életkörülményekkel való elégedettséggel határozta meg, melyet a korábbi fejezetben leírtak alapján az élettel való elégedettség kérdésével, mint közvetett változóval mértünk. Az életkörülményeiket 11 fokú skálán értékelve elégedetteknek tartottuk azokat a válaszadókat, akik a skála 6-tól 10-ig terjedő tartományában, elégedetleneknek pedig azokat, akik a 0-tól 4-ig terjedő fokozatok mentén értékelték életüket. ${ }^{14}$ [Hasonlóan kódolták hazai vizsgálatokban a kutatók az elégedetlenek csoportját, 0-tól 3-ig terjedő skálaértéket választókat tekintették elégedetleneknek (Andorka-Spéder, 1996).] Mindkét esetben dichotóm változókat hoztunk létre, az elégedettséget mérő mutatónál: $1=6$-tól 10 -ig terjedő skálafokokat, míg $0=5$ - 0

13 Itt már az átforgatott skála átlagai szerepelnek.

14 A csoportátlagok összehasonlításához a Kramer's V mutatót használtuk, mely a Khi-négyzet statisztika értékéhez kapcsolódó szimmetrikus mutató, az együttható a két változó közötti kapcsolat erősségét fejezi ki, mely akkor érdekes, ha a változók közötti összefüggés statisztikailag szignifikáns. 
közötti kategóriát választók; illetve az elégedetlenséget mérő mutatónál: az 1=0-tól 4-ig terjedő értékeket, míg $0=5$-től 10 -es skálafokokat választókat kódoltuk össze. (Az eredményeket a 2006 és 2012-es év vonatkozásában rendre, egymást követően közöljük. A részletes statisztikákat az F. 9. sz. Függelék táblázatai tartalmazzák.)

A válság előtt, 2006-ban a lakosság 62,5 százaléka volt elégedett és $\mathbf{1 7 , 5}$ százaléka elégedetlen az életével, a válságot követően 2012-ben ez az arány 54,4 és $30,2 \%$ volt. Tehát a fenti átlageredmény itt is megmutatkozik, magasabb, majdnem duplája az elégedetlenek arány a kilábalás éveit követően.

A kiemelten szedett mintabeli föarányokhoz képest mindkettő évben (2006, 2012) szignifikánsan magasabb az elégedettek aránya a 30 év alattiak (rendre: 72,3; 63,8), a felsőfokú végzettségüek $(78,2 ; 72,7)$, az aktívak $(65,5 ; 59,6)$, a ,jó és nagyon jó" egészségi állapotúak $(73,9 ; 65,2)$, az optimista szemlélettel rendelkezők $(72,0$; $68,8)$ és a magukat lakókörnyezetükben biztonságban érzők $(66,2 ; 68,0)$ között, és azok között, akik úgy érzik, nem küzdenek megélhetési problémákkal, mert kijönnek (72,3; 70,7), vagy kényelmesen megélnek a háztartás rendelkezésére álló jövedelméből $(86,5 ; 88,6)$.

Szignifikánsan többen számoltak be elégedetlenségről az alapfokú vagy kevesebb $(21,4 ; 37,7)$ és a szakmunkás végzettségűek $(21,0 ; 36,1)$, a munkaerőpiacról kívül rekedtek $(20,4 ; 35,0)$, a „rossz és nagyon rossz” egészségi állapotú $(37,3 ; 54,6)$, a pesszimista $(38,7 ; 63,7)$ és a biztonsághiányt érzők között $(25,7 ; 35,9)$, mint a teljes mintában, továbbá a megélhetési gondokkal küzdők csoportjaiban, ahol úgy érzik nagyon nehezen $(43,4 ; 57,2)$, vagy nehezen élnek meg $(21,9 ; 33,7)$ a rendelkezésre álló bevételeikből.

A településtípus szerinti csoportok 2006-ban nem, azonban 2012-ben szignifikáns eltérést mutattak, a főváros és elővárosában élők között többen vallották magukat elégedettnek $(62,8)$ és kevesebben elégedetlennek $(25,8)$, mint a teljes mintában. A házasok vagy élettársi kapcsolatban élők és az egyedülállók demográfiai csoportjai között 2006-ban nagyon gyenge volt a kapcsolat, alig valamivel többen voltak elégedettek a házasok között $(65,3)$, és elégedetlenek az egyedülállók körében $(20,0)$, mint a teljes mintában. Esetükben 2012-ben nem volt szignifikáns az eltérés. 


\section{A „Loving” dimenzió realizációja}

A dimenzió a szeretet, a kölcsönös törődés és támogatás létét, együttesen a támogatottságérzetet fejezi ki, mely értelmében a szociális szükségletek realizációs szintjét a támogatottságérzet mértékével mértük. Azokat tekintettük a szükséglettípust magas szinten realizáló válaszadóknak, akik a „teljesen egyetért” és „egyetért” választ adták. Azokat pedig alacsony szinten realizálóknak, akik a „nem ért egyet” és „egyáltalán nem ért egyet” kategóriákat választották, melyek alapján itt is kettő dichotóm változót hoztunk létre. A „támogatottságérzettel rendelkezők” változóját: $1=5,4 ;$ míg a többieket $0=3,2,1$ alapján kódoltuk, illetve a „támogatottságérzettel nem rendelkezők” mutatóját: 1=1,2, illetve a többieket 0=3,4,5-re kódoltuk. (A statisztikákat az F.9.2. sz. Függelék foglalja össze.)

Mindkettő évben a lakosság jelentős része érezte személyes életében a támogatottságérzetet: 2006-ban a minta 89,1 százaléka, 2012-ben 87\%-a értékelte úgy, hogy számíthat törődésre és személyes támogatásra közvetlen környezetéből, míg 3,3 és 4,9 százalék volt azok aránya, akik ilyenre nem számíthattak.

Azok között, akik magas támogatottságérzetről számoltak be, szignifikánsan többen voltak 30 év alattiak (rendre: 96,0;92,4), felsőfokú végzettségüek (94,6; 93,7), optimisták $(92,1 ; 91,6)$, olyanok, akik ,jó és nagyon jó” egészségi állapotnak örvendtek $(93,6 ; 89,8)$, illetve akik kényelmesen megéltek a jövedelmükből (94,2; 95,9). Azonban szignifikánsan kevesebb arányban számoltak be támogatottságérzetről azok, akik nem dolgoztak $(85,0 ; 84,9)$. A teljes mintabeli arányokhoz képest az alapfokú, vagy kevesebb iskolai végzettséggel rendelkezők $(6,3 ; 7,8)$, a munkaerő-piacon kívül rekedtek $(5,2 ; 6,8)$, a „rossz és nagyon rossz” egészségi állapotúak $(7,9 ; 11,6)$ és a pesszimisták között $(8,5 ; 11,9)$ szignifikánsan többen voltak azok, akik úgy érezték, nem számíthatnak törődésre, támogatásra. A nem, településtípus, biztonságérzet szerinti csoportok nem mutattak szignifikáns eltérést a mintabeli arányokhoz képest.

\section{A „Being” dimenzió realizációja}

A Being dimenzió a személyes fejlődés szükségletét fejezi ki, mely az önmegvalósítás és kiteljesedés érzését kapcsolja össze. Az önmegvalósítás egyéni mértéke alapján a megkérdezettek ötfokú skálán értékelték realizációs szintjüket. Az operacionalizát kérdéssel (Úgy érzem, amivel foglalkozom, az értékes és megéri a 
fáradtságot) „teljesen egyetértőket” és az „egyetértőket” tekintettük azoknak, akik ezt a típusú szükségeltet magas szinten realizálják. A skála másik kettő végpontját választókat pedig az alacsony szinten realizálóknak. A két dichotóm változó kialakítása itt is a fentiek szerint történt. (Lásd az F.9.3. sz. Függelék táblázatait.) A megkérdezettek között $\mathbf{7 2 , 3 \%}$ (2006) és 66,0\% (2012) volt azok aránya, akik az önmegvalósítókhoz sorolták magukat, míg csupán a 6,5 és 9,6 százalék érezte úgy, hogy nem tudott kiteljesedni az életében.

Önmegvalósítókat elsősorban a felsőfokú végzettségüek $(86,6 ; 81,5)$, az optimisták $(82,4 ; 80,6)$, a ,jó és nagyon jó” egészségnek örvendők $(79,1 ; 72,0)$, és az anyagi problémák nélkül élők (kijövünk: 79,0; 75,5 és kényelmesen megélünk: 77,3; 78,9) között találunk szignifikánsan nagyobb arányban, mint a teljes mintában.

Azok, akik önmegvalósításuk hiányáról számoltak be, szignifikánsan többen voltak az alapfokú vagy alacsonyabb iskolai végzettségü $(9,8 ; 17,9)$, a munkaerőpiacon kívül rekedtek $(9,7 ; 13,4)$, a „rossz és nagyon rossz” egészségi állapotú $(17,7$; $27,4)$, és a pesszimista $(19,4 ; 25,1)$ válaszadók csoportjaiban. A nem és a településtípus eltérő csoportjai nem mutattak szignifikáns eltérést az önmegvalósítás eltérő realizációs szintjeiben a teljes mintabeli arányokhoz képest. Az életkori korcsoportok 2006-ban nem tértek el szignifikánsan, azonban 2012-ben a 30-39 évesek között szignifikánsan többen $(73,5)$ voltak, akik magas realizációs szintet értek el.

\section{Az életminőség és jóllét tartós és rövid távú érzelmi percepciói}

Kutatásunkban az életminőség tartós érzelmi percepcióját a boldogságérzet mértéke fejezi ki, melyet 11 fokú létrán mértek mindkét évben. Az elégedettséget mérő indikátorhoz hasonlóan létrehoztuk a boldogok dichotóm mutatóját (1=6-tól 10-ig terjedő skálafokok, 0=0-tól 5-ig terjedő kategóriák), illetve a boldogtalanok változóját (1=0-tól 4-ig terjedő skálafokok, $0=5$-től 10-ig terjedő kategóriák), és azt vizsgáltuk meg, hogy mely társadalmi-demográfiai csoportokban vannak többen olyan egyének, akik e mérőeszköz mentén magasabb életminőségről számoltak be. (Lásd az F.9.4. sz. Függeléket.)

Az eredmények alapján 2006-ban 63,9 százalék, 2012-ben 61,5\% volt azok aránya, akik életüket általában boldognak értékelték, míg 17,1 és 21,4\% azoké, akik boldogtalannak. Mindkettő évben többen adtak kedvező érzelmi értékelést életükről 
a 30 év alattiak (rendre: 78,8; 72,0), a magas iskolai végzettségüek $(78,6 ; 75,4)$, a házasságban vagy élettársi kapcsolatban élők $(66,4 ; 65,5)$, a munkaerö-piacon jelen lévők $(66,8 ; 68,9)$, a ,jó és nagyon jó" egészségi állapottal $(78,1 ; 73,0)$ és a biztonságérzettel rendelkezők $(68,6 ; 65,0)$, illetve az optimisták $(75,6 ; 76,4)$ és a megélhetési gondoktól mentes életet élők körében $(84,9 ; 91,1)$, mint a teljes mintában. Szignifikánsan boldogtalanabbak az idősebb életkori korcsoportok, elsősorban a 70 évtől idősebbek $(23,2 ; 31,5)$, továbbá az alapfokú vagy alacsonyabb iskolai végzettségüek $(20,9 ; 32,4)$, akik nem dolgoznak $(21,2 ; 27,2)$, a „rossz és nagyon rossz" egészségi állapotúak $(45,0 ; 47,6)$, a biztonsághiányt szenvedők $(26,0$; $27,2)$, és a mindennapi anyagi problémákkal küzdők $(41,3 ; 42,6)$.

A hétköznapi frusztrációk, aggodalom, stressz hatással vannak életünk minőségére, jóllétünkre. Ezeknek az átmeneti érzéseknek a gyakorisága, jelenléte szintén hozzájárul ahhoz, hogy napjaink mennyire nyugodtak vagy nyugtalanok, mennyire élvezzük az életünket, vagy vagyunk levertek, depressziósak. Ezen rövid távú, időszakos és eltérő tartalmú emóciók mérlegét a Balansz Skála méri, melynek segítségével itt egy változóval dolgoztunk, a dichotóm csoportot képezték egyrészt azok az egyének, akik az átlag feletti, vagyis pozitív érzelmi egyenlegről számoltak be, másrészt azok, akik átlag alatti, negatív egyenleget mutattak. (Lásd az F.9.5. sz. Függeléket.)

Pozitív érzelmi egyenleget a minta 53,2 (2006) és 52,9 (2012) százaléka esetében mértünk, a negatív balansz a skála másik fele alapján 46,8 és 47,1\%. (A továbbiakban a pozitív egyenleg csoportjába tartozókat viszonyítjuk a teljes mintához.) Mindkettő évben szignifikánsan többen mutattak pozitív érzelmi egyenleget a fiatalok (rendre: 67,2; 64,8), a képzettek (felsőfokú: 64,1; 69,4), a munkaerő-piacon jelen lévők $(56,5 ; 59,8)$, a kedvező egészséggel (,jó és nagyon jó": $69,0 ; 65,7)$ és biztonságérzettel rendelkezők $(57,7 ; 56,6)$, továbbá az optimisták $(64,4$; 67,6) és a megélhetési gondok nélkül élők (kényelmesen megélünk: 64,4; 87,5) lakosok körében. Gyengébb az összefüggés, de szignifikáns a férfiak $(56,3 ; 55,5)$ és a házasságban vagy élettársi kapcsolatban élők $(55,5 ; 56,4)$ között.

Összegezve a szubjektív életminőséget mérő szükséglettípusoknak a lakosság körében mért realizációs szintjeit és az érzelmi állapotokat, a két időpontban felvett adatok alapján az eltérő társadalmi-demográfiai csoportokon belüli arányokat 
tekintve az alábbiak mondhatók el: a nem és a családi állapot szerint kialakított társadalmi metszetekben általában nem térnek el a csoportok szignifikánsan a mintabeli arányoktól. Az időbeli összevetés alapján, ahol szignifikánsak voltak 2006-ban az eltérések, ott nagyjából hasonló erősségü összefüggéseket mértünk 2012-ben is. A fiatalok, a diplomások, illetve a dolgozók a társadalmi átlagtól magasabb szinten realizálják az eltérő szükséglettípusokat, illetve a tartós vagy időszakos érzelmi percepcióik is kedvezőbbek, mint a többi csoporté. Az életkori korcsoportok esetében általában hasonló erősségü kapcsolatokat mértünk mindegyik fö dimenzió terén mindkét évben. Az iskolai végzettség szerinti csoportokban 2006hoz képest mind az öt életminőség dimenzióban erősebb kapcsolatot találtunk 2012ben, míg a munkaerő-piaci jelenlét szerinti csoportokban négy alskála esetében valamelyest erősebb összefüggést, a támogatottságérzet esetében azonban gyengébb kapcsolatot mértünk a válság előtti időszakhoz képest.

A szubjektív ismérvek alapján a jó egészségi állapotúak, a lakókörnyékükön magukat biztonságban érzők, az optimista szemlélettel rendelkezők, és azok az egyének, akik úgy érzik, nincsenek megélhetési problémáik, általában minden esetben lakossági átlagtól szignifikánsan magasabb realizációs szinteteket és kedvezőbb érzelmi egyenleget értek el a többi csoporthoz képest. A szubjektív egészségi állapot szerinti csoportokban a két időszak között az öt dimenzióban hasonló erősségű összefüggéseket találtunk. A biztonságérzet alapján kialakított csoportoknál az összefüggések 2012-re valamelyest veszítettek erejükből, míg a személyes beállítottság és a szubjektív jövedelem csoportjainál mind az öt életminőség dimenzióban a válságot követően erősebb volt a kapcsolat, mint 2006ban. Az összefüggések erősségének változása a támogatottságérzet esetében a változó aszimmetrikus megoszlásával és az elidegenedésérzet általános növekedésével hozható összefüggésbe. A többi esetben az összefüggés erősségének változása feltehetően a csoportarányok változásának köszönhető, mely egyrészt a társadalom polarizálódásával, illetve az optimizmus esetében a 2010-es év hatásával is magyarázható. 


\subsection{A szubjektív életminőség összetevőinek meghatározó tényezői}

Az előző fejezetben a népesség eltérő társadalmi-demográfiai csoportjait jellemeztük az eltérő szükséglettípusokban elért realizációs szintek és tartós vagy időszakos érzelmi állapotok vizsgálata alapján. Mielőtt rátérnénk a többdimenziós szubjektív életminőség vizsgálatára, az összetett indikátor öt elemének az alakulását vizsgáljuk meg a magyar lakosság körében a gazdasági válság előtt és azt követően. Ennek érdekében az „Adatok és módszerek” alfejezetben leírtak alapján a regressziós elemzéseket a kompozit index alskáláira futtatjuk le, első lépésben a társadalmi-demográfia változókra, majd a második modellben a további magyarázó változóknak a bevonásával együttesen. Az eltérő csoportok jellemzőit a szetnderdizálatlan béta paraméterek figyelembe vételével elemezzük.

A válságot megelőző időszakról (10. táblázat) a becslések alapján elmondhatjuk, hogy a 30 évtől fiatalabbak csoportjához viszonyítva mindegyik életkori korcsoport esetében kedvezőtlenebb átlagos szubjektív életminőséget mértünk, mind az öt alskálán. Azonban amíg az aktív éveikben járó 40-49 éveseknél a having és a loving dimenziókban, az 50-59 éveseknél a having, loving és a boldogság skálákon, addig a 70 évesek vagy idősebbek korcsoportjánál az érzelmi balansz-skálán találtuk a legjelentőseb negatív irányú eltéréseket. A válság utáni időszakban (11. táblázat) pedig az látható, hogy elsősorban két életkori korcsoport, a 60-69 évesek és a 70 évesek vagy idősebbek átlagos egységnyi skálaértékváltozásai jeleztek jelentősebb romlást a having, loving dimenziókban és a Balansz-skála mutatóin. Pozitív irányú változást elsősorban a 30-39 évesek esetében a javuló érzelmi egyenleg alapján tapasztaltunk. A településtípus szerinti csoportok alapvetően nem mutattak szignifikáns kapcsolatot az alskálákkal 2006-ban, azonban 2012-re a nagyvárosi élet átlagosan alacsonyabb pontértéket mutatott a boldogság skálán, illetve a loving és a being dimenziókban, jóllehet gyenge összefüggés mellett. 
10. táblázat: A szubjektív életminőség öt fö összetevőjének (having, loving, being, boldogság, érzelmi balansz) regressziós modelljei, 2006, OLS (sztenderdizálatlan regressziós együtthatók, szignifikancia szintek)

\begin{tabular}{|c|c|c|c|c|c|}
\hline & Having & Loving & Being & Boldogság & Balansz \\
\hline Nem & $\begin{array}{l}-0,079 \\
(0,146)\end{array}$ & $\begin{array}{l}-0,090 \\
(0,047)\end{array}$ & $\begin{array}{l}-0,100 * \\
(0,054)\end{array}$ & $\begin{array}{l}-0,022 \\
(0,141)\end{array}$ & $\begin{array}{c}0,383 * * \\
(0,141)\end{array}$ \\
\hline $\begin{array}{l}\text { Életkor: 30-39 } \\
\text { éves }\end{array}$ & $\begin{array}{c}-0,909 * * * \\
(0,236)\end{array}$ & $\begin{array}{c}-0,175 * * \\
(0,076)\end{array}$ & $\begin{array}{l}-0,036 \\
(0,088)\end{array}$ & $\begin{array}{c}-0,603 * * \\
(0,228)\end{array}$ & $\begin{array}{c}-1,024 * * * \\
(0,229)\end{array}$ \\
\hline 40-49 éves & $\begin{array}{c}-1,243 * * * \\
(0,231)\end{array}$ & $\begin{array}{c}-0,394 * * * \\
(0,074)\end{array}$ & $\begin{array}{l}-0,106 \\
(0,086)\end{array}$ & $\begin{array}{c}-\mathbf{0 , 8 8 1} * * * \\
(0,223)\end{array}$ & $\begin{array}{c}-1,262 * * * \\
(0,224)\end{array}$ \\
\hline 50-59 éves & $\begin{array}{c}-1,153 * * * \\
(0,226)\end{array}$ & $\begin{array}{c}-0,320 * * * \\
(0,073)\end{array}$ & $\begin{array}{c}-0,150 * \\
(0,084)\end{array}$ & $\begin{array}{c}-1,103 * * * \\
(0,218)\end{array}$ & $\begin{array}{c}-0,984 * * * \\
(0,219)\end{array}$ \\
\hline 60-69 éves & $\begin{array}{c}-0,794 * * * \\
(0,242)\end{array}$ & $\begin{array}{c}-0,199 * * \\
(0,078)\end{array}$ & $\begin{array}{l}-0,075 \\
(0,090)\end{array}$ & $\begin{array}{c}-0,925 * * * \\
(0,234)\end{array}$ & $\begin{array}{c}-1,172 * * * \\
(0,235)\end{array}$ \\
\hline $\begin{array}{l}70 \text { éves vagy } \\
\text { idősebb }\end{array}$ & $\begin{array}{c}-0,601 * * \\
(0,255)\end{array}$ & $\begin{array}{c}-0,166^{* * *} \\
(0,082)\end{array}$ & $\begin{array}{c}-0,299 * * \\
(0,095)\end{array}$ & $\begin{array}{c}-0,914 * * * \\
(0,247)\end{array}$ & $\begin{array}{c}-1,439 * * * \\
(0,247)\end{array}$ \\
\hline $\begin{array}{l}\text { Nagyváros és } \\
\text { elővárosa }\end{array}$ & $\begin{array}{c}0,226 \\
(0,188)\end{array}$ & $\begin{array}{l}-0,080 \\
(0,060)\end{array}$ & $\begin{array}{l}-0,120 * \\
(0,070)\end{array}$ & $\begin{array}{l}-0,069 \\
(0,182)\end{array}$ & $\begin{array}{c}0,083 \\
(0,182)\end{array}$ \\
\hline $\begin{array}{l}\text { Város vagy } \\
\text { kisváros }\end{array}$ & $\begin{array}{c}0,083 \\
(0,163)\end{array}$ & $\begin{array}{c}0,008 \\
(0,053)\end{array}$ & $\begin{array}{l}-0,038 \\
(0,061)\end{array}$ & $\begin{array}{l}-0,131 \\
(0,158)\end{array}$ & $\begin{array}{c}0,010 \\
(0,158)\end{array}$ \\
\hline $\begin{array}{l}\text { Szakmunkás/ } \\
\text { szakiskola }\end{array}$ & $\begin{array}{c}-0,503 * * \\
(0,193)\end{array}$ & $\begin{array}{c}0,067 \\
(0,062)\end{array}$ & $\begin{array}{c}0,062 \\
(0,072)\end{array}$ & $\begin{array}{l}-0,259 \\
(0,187)\end{array}$ & $\begin{array}{c}0,063 \\
(0,187)\end{array}$ \\
\hline Érettségi & $\begin{array}{c}0,164 \\
(0,198)\end{array}$ & $\begin{array}{c}0,137 * * \\
(0,064)\end{array}$ & $\begin{array}{c}0,231 * * \\
(0,074)\end{array}$ & $\begin{array}{c}0,250 \\
(0,192)\end{array}$ & $\begin{array}{c}0,734 * * * \\
(0,192)\end{array}$ \\
\hline Felsőfokú & $\begin{array}{c}0,649 * * \\
(0,236) \\
\end{array}$ & $\begin{array}{c}0,219 * * \\
(0,076)\end{array}$ & $\begin{array}{c}0,527 * * * \\
(0,088)\end{array}$ & $\begin{array}{l}0,623 * * \\
(0,228)\end{array}$ & $\begin{array}{c}0,986 * * * \\
(0,229)\end{array}$ \\
\hline $\begin{array}{l}\text { Egy före jutó } \\
\text { havi nettó } \\
\text { háztartási } \\
\text { jövedelem }\end{array}$ & $\begin{array}{c}\text { 6,599E-6*** } \\
(0,000)\end{array}$ & $\begin{array}{c}1,150 \mathrm{E}-6 * * * \\
(0,000)\end{array}$ & $\begin{array}{c}1,076 \mathrm{E}-6 * * \\
(0,000)\end{array}$ & $\begin{array}{c}5,943 \mathrm{E}-6 * * * \\
(0,000)\end{array}$ & $\begin{array}{c}2,472 \mathrm{E}-6 * * \\
(0,000)\end{array}$ \\
\hline Konstans (B) & $\begin{array}{c}5,210 * * * \\
(0,248)\end{array}$ & $\begin{array}{c}4,329 * * * \\
(0,080)\end{array}$ & $\begin{array}{c}3,778 * * * \\
(0,092)\end{array}$ & $\begin{array}{c}6,277 * * * \\
(0,240)\end{array}$ & $\begin{array}{c}1,451 * * * \\
(0,240)\end{array}$ \\
\hline Korrigált $\mathbf{R}^{2}$ & 0,091 & 0,043 & 0,059 & 0,075 & 0,086 \\
\hline
\end{tabular}

Megjegyzés: a zárójelben szereplö számok sztenderd hibák. Referencia kategóriák: nö, 30 évtől fiatalabb, falu+község+tanya, 8 általános vagy kevesebb. Hiányzó esetek kezelése: pairwise, ezért az $N$-eket itt nem közlöm, mert azok változópáronként különböznek. Szignifikancia szintek: $* p<0.10, * * p<0.05, * * * p<0.01$ 
11. táblázat: A szubjektív életminőség öt fö összetevőjének (having, loving, being, boldogság, érzelmi balansz) regressziós modelljei, 2012, OLS (sztenderdizálatlan regressziós együtthatók, szignifikancia szintek)

\begin{tabular}{|c|c|c|c|c|c|}
\hline & Having & Loving & Being & Boldogság & Balansz \\
\hline Nem & $\begin{array}{l}-0,042 \\
(0,127)\end{array}$ & $\begin{array}{c}-0,091 \\
(0,068)\end{array}$ & $\begin{array}{l}-0,029 \\
(0,051)\end{array}$ & $\begin{array}{l}-0,167 \\
(0,119)\end{array}$ & $\begin{array}{l}0,257 * * \\
(0,123)\end{array}$ \\
\hline $\begin{array}{l}\text { Életkor: 30-39 } \\
\text { éves }\end{array}$ & $\begin{array}{c}-0,895 * * * \\
(0,205)\end{array}$ & $\begin{array}{c}-0,355 * * * \\
(0,109)\end{array}$ & $\begin{array}{c}0,043 \\
(0,082)\end{array}$ & $\begin{array}{c}-0,584 * * \\
(0,191)\end{array}$ & $\begin{array}{c}-0,535 * * \\
(0,198)\end{array}$ \\
\hline 40-49 éves & $\begin{array}{c}-1,168 * * * \\
(0,200)\end{array}$ & $\begin{array}{c}-0,423 * * * \\
(0,106)\end{array}$ & $\begin{array}{c}0,000 \\
(0,080)\end{array}$ & $\begin{array}{c}-0,956 * * * \\
(0,187)\end{array}$ & $\begin{array}{c}-0,892 * * * \\
(0,194)\end{array}$ \\
\hline 50-59 éves & $\begin{array}{c}-1,268 * * * \\
(0,206)\end{array}$ & $\begin{array}{c}-0,327 * * \\
(0,109)\end{array}$ & $\begin{array}{c}0,085 \\
(0,083)\end{array}$ & $\begin{array}{c}-1,133 * * * \\
(0,192)\end{array}$ & $\begin{array}{c}-1,253 * * * \\
(0,199)\end{array}$ \\
\hline 60-69 éves & $\begin{array}{c}-1,082 * * * \\
(0,217)\end{array}$ & $\begin{array}{c}-0,430 * * * \\
(0,116)\end{array}$ & $\begin{array}{l}-0,040 \\
(0,087)\end{array}$ & $\begin{array}{c}-1,207 * * * \\
(0,203)\end{array}$ & $\begin{array}{c}-1,314 * * * \\
(0,210)\end{array}$ \\
\hline $\begin{array}{l}70 \text { éves vagy } \\
\text { idősebb }\end{array}$ & $\begin{array}{l}-, 844 * * * \\
(0,224)\end{array}$ & $\begin{array}{c}-0,352 * * \\
(0,119)\end{array}$ & $\begin{array}{c}-, 0288 * * * \\
(\mathbf{0 , 0 9 0 )}\end{array}$ & $\begin{array}{c}-1,336 * * * \\
(0,209)\end{array}$ & $\begin{array}{c}-1,517 * * * \\
(0,217)\end{array}$ \\
\hline $\begin{array}{l}\text { Nagyváros és } \\
\text { elővárosa }\end{array}$ & $\begin{array}{c}0,069 \\
(0,167)\end{array}$ & $\begin{array}{c}-0,239 * * \\
(0,089)\end{array}$ & $\begin{array}{c}-0,147 * * \\
(0,067)\end{array}$ & $\begin{array}{c}-0,342 * * \\
(0,156)\end{array}$ & $\begin{array}{l}-0,088 \\
(0,161)\end{array}$ \\
\hline $\begin{array}{l}\text { Város vagy } \\
\text { kisváros }\end{array}$ & $\begin{array}{c}0,134 \\
(0,147)\end{array}$ & $\begin{array}{l}-0,020 \\
(0,078)\end{array}$ & $\begin{array}{l}-0,022 \\
(0,059)\end{array}$ & $\begin{array}{l}-0,125 \\
(0,137)\end{array}$ & $\begin{array}{l}-0,101 \\
(0,142)\end{array}$ \\
\hline $\begin{array}{l}\text { Szakmunkás/ } \\
\text { szakiskola }\end{array}$ & $\begin{array}{l}-0,035 \\
(0,167)\end{array}$ & $\begin{array}{c}0,012 \\
(0,089)\end{array}$ & $\begin{array}{l}0,156 * * \\
(0,067)\end{array}$ & $\begin{array}{c}0,073 \\
(0,156)\end{array}$ & $\begin{array}{c}0,211 \\
(0,161)\end{array}$ \\
\hline Érettségi & $\begin{array}{c}0,243 \\
(0,171)\end{array}$ & $\begin{array}{c}0,379 * * * \\
(0,091)\end{array}$ & $\begin{array}{c}0,249 * * * \\
(0,069)\end{array}$ & $\begin{array}{l}0,440 * * \\
(0,160)\end{array}$ & $\begin{array}{l}0,446 * * \\
(0,166)\end{array}$ \\
\hline Felsőfokú & $\begin{array}{c}1,192 * * * \\
(0,206)\end{array}$ & $\begin{array}{c}\mathbf{0 , 6 1 8} * * * \\
(\mathbf{0 , 1 1 0})\end{array}$ & $\begin{array}{c}\mathbf{0 , 6 0 6} * * * \\
(\mathbf{0 , 0 8 3 )}\end{array}$ & $\begin{array}{c}1,131 * * * \\
(0,192)\end{array}$ & $\begin{array}{c}1,134 * * * \\
(0,199)\end{array}$ \\
\hline $\begin{array}{l}\text { Egy före jutó havi } \\
\text { nettó háztartási } \\
\text { jövedelem }\end{array}$ & $\begin{array}{c}8,529 \mathrm{E}-6 * * * * \\
(0,000)\end{array}$ & $\begin{array}{c}3,522 \mathrm{E}-7 \\
(0,000)\end{array}$ & $\begin{array}{c}6,089 \mathrm{E}-8 \\
(0,000)\end{array}$ & $\begin{array}{c}4,796 \mathrm{E}-6 * * * \\
(0,000)\end{array}$ & $\begin{array}{c}\text { 7,232E-6**** } \\
(\mathbf{0 , 0 0 0 )}\end{array}$ \\
\hline Konstans (B) & $\begin{array}{c}5,540 * * * \\
(0,191)\end{array}$ & $\begin{array}{c}6,178 * * * \\
(0,102)\end{array}$ & $\begin{array}{c}3,616^{* * * *} \\
(0,077)\end{array}$ & $\begin{array}{c}6,495^{* * * *} \\
(0,179)\end{array}$ & $\begin{array}{c}1,406^{* * * *} \\
(0,185)\end{array}$ \\
\hline Korrigált $\mathbf{R}^{2}$ & 0,091 & 0,044 & 0,055 & 0,076 & 0,095 \\
\hline
\end{tabular}

Megjegyzés: a zárójelben szereplö számok sztenderd hibák. Referencia kategóriák: nö, 30 évtöl fiatalabb, falu+község+tanya, 8 általános vagy kevesebb. Hiányzó esetek kezelése: pairwise, ezért az N-eket itt nem közlöm, mert azok változópáronként különböznek. Szignifikancia szintek: ${ }^{*} p<0.10, * * p<0.05, * * * p<0.01$

$\mathrm{Az}$ iskolai végzettség és az egy före jutó háztartási jövedelem kapcsolata mindkét időszakban - néhány dimenziótól eltekintve - szignifikáns pozitív öszefüggést mutatott. Azoban a recesszió éveiben a felsőfokú végzettségủek esetében figyelhettünk meg jelentős mértékű javulást 2012-re mind az öt alsákála esetében. Az érettségit megszerző középfokú végzettségüek is kedvezőbb átlagos különbségeket mutatnak a válság előtti értékekhez képest a referenciacsoporthoz viszonytíva, azonban amíg a boldoság index javulást, az 
balansz-skála jelentős csökkenést mutatott esetükben. $\mathrm{Az}$ egy före jutó jövedelem pedig a loving és a being dimenziókon 2012-re elveszítette szignifikáns voltát.

$\mathrm{Az}$ eddig bemutatottak alapján összességében annyit mondhatunk el, hogy amíg elsősorban a 70 évesek vagy idősebbek szubjektív életminősége esett vissza leginkább a recesszió évei alatt, addig a felsőfokú iskolai végzettségủek jólléte mutatta a legjelentősebb javulást a válság után. A nem és a településtípus nem befolyásolta a jóllét-dimenziók az alakulását, azonban a nagyvárosban élők szubjektív életminőségét a válság valamelyest lerontotta.

A második lépésben az öt alskálára felépített regressziós modellek vizsgálatát a kutatáshoz kiválasztott további magyarázó változók bevonása mellett végeztük el (12-13. táblázatok). Tekintettel arra, hogy ezen változók között szubjektív magyarázó változó is szerepelnek, emlékeztetünk a korábban már hivatkozott tényekre, összefüggésekre és szakirodalomra, de elsősorban arra, hogy a szubjektív magyarázó változók bevonása a többváltozós modellek magyarázott variancia értékeit minden esetben jelentős mértékben javították (Michalos-Zumbo, 2000, 2002; Spéder-Kapitány, 2002; Lengyel-Janky, 2003; Keller, 2008). 
12. táblázat: A szubjektív életminőség öt fö összetevőjének (having, loving, being, boldogság, érzelmi balansz) integrált regressziós modelljei, 2006, OLS (sztenderdizálatlan regressziós együtthatók, szignifikancia szintek)

\begin{tabular}{|c|c|c|c|c|c|}
\hline & Having & Loving & Being & Boldogság & Balansz \\
\hline Férfi & $\begin{array}{l}-0,117 \\
(0,136)\end{array}$ & $\begin{array}{c}-0,091 * * \\
(0,044)\end{array}$ & $\begin{array}{l}-0,114 * * \\
(0,049)\end{array}$ & $\begin{array}{c}-0,098 \\
(0,124)\end{array}$ & $\begin{array}{c}0,298 * * \\
(0,124)\end{array}$ \\
\hline Életkor: 30-39 éves & $\begin{array}{c}-0,576 * * \\
(0,231)\end{array}$ & $\begin{array}{c}-\mathbf{- 0 , 1 4 0 *} \\
(0,075)\end{array}$ & $\begin{array}{c}0,051 \\
(0,084)\end{array}$ & $\begin{array}{c}-\mathbf{- 0 , 4 7 3} * * \\
(\mathbf{0 , 2 1 1})\end{array}$ & $\begin{array}{c}-0,742 * * * * \\
(0,212)\end{array}$ \\
\hline 40-49 éves & $\begin{array}{c}-0,726 * * \\
(0,232)\end{array}$ & $\begin{array}{c}-0,321 * * * \\
(0,075)\end{array}$ & $\begin{array}{c}0,045 \\
(0,084)\end{array}$ & $\begin{array}{c}-\mathbf{0 , 5 7 8} * * \\
(0,211)\end{array}$ & $\begin{array}{c}-0,778 * * * \\
(0,212)\end{array}$ \\
\hline 50-59 éves & $\begin{array}{c}-0,770 * * * \\
(0,222)\end{array}$ & $\begin{array}{c}-0,268 * * * * \\
(0,072)\end{array}$ & $\begin{array}{c}-0,021 \\
(0,080)\end{array}$ & $\begin{array}{c}-\mathbf{- 0 , 8 8 4} * * * * \\
(\mathbf{0 , 2 0 2})\end{array}$ & $\begin{array}{c}-0,569 * * \\
(0,204) \\
\end{array}$ \\
\hline 60-69 éves & $\begin{array}{c}-0,566 * * \\
(0,242)\end{array}$ & $\begin{array}{c}-0,173 * * \\
(0,079)\end{array}$ & $\begin{array}{c}0,021 \\
(0,087)\end{array}$ & $\begin{array}{c}-\mathbf{0 , 8 5 7} * * * * \\
(0,220)\end{array}$ & $\begin{array}{c}-0,854 * * * \\
(0,221)\end{array}$ \\
\hline 70 éves vagy idősebb & $\begin{array}{c}-0,238 \\
(0,254)\end{array}$ & $\begin{array}{c}-0,116 \\
(0,083) \\
\end{array}$ & $\begin{array}{l}-\mathbf{0 , 1 6 1 *} \\
(\mathbf{0 , 0 9 2 )} \\
\end{array}$ & $\begin{array}{c}-0,535 * * \\
(0,231) \\
\end{array}$ & $\begin{array}{c}-\mathbf{0 , 8 7 1} * * * \\
(0,233)\end{array}$ \\
\hline Nagyváros és elővárosa & $\begin{array}{c}0,205 \\
(0,176)\end{array}$ & $\begin{array}{l}-0,045 \\
(0,057)\end{array}$ & $\begin{array}{c}-0,083 \\
(0,064)\end{array}$ & $\begin{array}{c}0,064 \\
(0,160)\end{array}$ & $\begin{array}{c}0,176 \\
(0,161)\end{array}$ \\
\hline Város vagy kisváros & $\begin{array}{c}0,104 \\
(0,152)\end{array}$ & $\begin{array}{c}0,006 \\
(0,049)\end{array}$ & $\begin{array}{l}-0,034 \\
(0,055)\end{array}$ & $\begin{array}{l}-0,035 \\
(0,139)\end{array}$ & $\begin{array}{c}0,084 \\
(0,139)\end{array}$ \\
\hline Szakmunkás/szakiskola & $\begin{array}{c}-0,672 * * * \\
(0,181)\end{array}$ & $\begin{array}{c}0,037 \\
(0,059) \\
\end{array}$ & $\begin{array}{c}0,031 \\
(0,065) \\
\end{array}$ & $\begin{array}{c}-0,460 * * \\
(0,165)\end{array}$ & $\begin{array}{l}-0,070 \\
(0,166)\end{array}$ \\
\hline Érettségi & $\begin{array}{c}-0,456 * * \\
(0,189)\end{array}$ & $\begin{array}{c}0,000 \\
(0,061)\end{array}$ & $\begin{array}{c}0,051 \\
(0,068)\end{array}$ & $\begin{array}{l}-0,414 * * \\
(0,172)\end{array}$ & $\begin{array}{c}0,153 \\
(0,173)\end{array}$ \\
\hline Felsőfokú & $\begin{array}{c}-0,248 \\
(0,229)\end{array}$ & $\begin{array}{c}0,008 \\
(0,074)\end{array}$ & $\begin{array}{l}0,240 * * \\
(0,083)\end{array}$ & $\begin{array}{l}-0,375^{*} \\
(0,209)\end{array}$ & $\begin{array}{c}0,078 \\
(0,210)\end{array}$ \\
\hline $\begin{array}{l}\text { Egy före jutó havi nettó } \\
\text { háztartási jövedelem }\end{array}$ & $\begin{array}{c}2,419 \mathrm{E}-6^{* * *} \\
(0,000)\end{array}$ & $\begin{array}{c}4,801 \mathrm{E}-7 \\
(0,000)\end{array}$ & $\begin{array}{l}1,805 \mathrm{E}-7 \\
(0,000)\end{array}$ & $\begin{array}{l}1,898 \mathrm{E}-6^{*} \\
(0,000)\end{array}$ & $\begin{array}{c}-3,543 \mathrm{E}-7 \\
(0,000)\end{array}$ \\
\hline Házas/élettárssal él & $\begin{array}{c}0,033 \\
(0,148) \\
\end{array}$ & $\begin{array}{c}0,057 \\
(0,048) \\
\end{array}$ & $\begin{array}{c}0,024 \\
(0,054)\end{array}$ & $\begin{array}{l}0,592 * * * \\
(0,135)\end{array}$ & $\begin{array}{c}0,153 \\
(0,136) \\
\end{array}$ \\
\hline Dolgozik & $\begin{array}{l}-0,083 \\
(0,165)\end{array}$ & $\begin{array}{c}0,017 \\
(0,054)\end{array}$ & $\begin{array}{c}0,014 \\
(0,060) \\
\end{array}$ & $\begin{array}{c}-0,197 \\
(0,150)\end{array}$ & $\begin{array}{l}-0,125 \\
(0,151)\end{array}$ \\
\hline $\begin{array}{l}\text { Kijönnek a havi } \\
\text { bevételeikböl }\end{array}$ & $\begin{array}{c}1,311 * * * \\
(0,149)\end{array}$ & $\begin{array}{c}0,018 \\
(0,049) \\
\end{array}$ & $\begin{array}{c}0,033 \\
(0,054)\end{array}$ & $\begin{array}{l}0,661 * * * \\
(0,136)\end{array}$ & $\begin{array}{l}0,290 * * \\
(0,137)\end{array}$ \\
\hline Jó szubjektív egészség & $\begin{array}{c}0,137 * * * * \\
(0,197)\end{array}$ & $\begin{array}{c}0,033 \\
(0,064) \\
\end{array}$ & $\begin{array}{c}0,096 \\
(0,071) \\
\end{array}$ & $\begin{array}{l}0,970 * * * \\
(0,180)\end{array}$ & $\begin{array}{c}0,961 * * * \\
(0,181)\end{array}$ \\
\hline Van biztonságérzete & $\begin{array}{c}0,629 \\
(0,160)\end{array}$ & $\begin{array}{l}-0,048 \\
(0,052)\end{array}$ & $\begin{array}{c}0,006 \\
(0,058)\end{array}$ & $\begin{array}{l}0,358 * * \\
(0,146) \\
\end{array}$ & $\begin{array}{c}0,426 * * \\
(0,147) \\
\end{array}$ \\
\hline $\begin{array}{l}\text { Anómia és } \\
\text { elidegenedésérzet }\end{array}$ & $\begin{array}{c}-0,229 * * * \\
(0,026)\end{array}$ & $\begin{array}{c}-0,122 * * * \\
(0,009)\end{array}$ & $\begin{array}{c}-0,143 * * * * \\
(0,010)\end{array}$ & $\begin{array}{c}-0,329 * * * * \\
(0,024)\end{array}$ & $\begin{array}{c}-0,328 * * * * \\
(0,024)\end{array}$ \\
\hline Optimista & $\begin{array}{c}0,353 * * \\
(0,137) \\
\end{array}$ & $\begin{array}{c}0,001 \\
(0,044)\end{array}$ & $\begin{array}{c}0,184 * * * \\
(0,049)\end{array}$ & $\begin{array}{c}0,448 * * * \\
(0,124)\end{array}$ & $\begin{array}{c}0,612 * * * * \\
(0,125)\end{array}$ \\
\hline Konstans (B) & $\begin{array}{c}6,472 * * * \\
(0,446)\end{array}$ & $\begin{array}{c}5,551 * * * \\
(0,145)\end{array}$ & $\begin{array}{c}5,020 * * * \\
(0,162)\end{array}$ & $\begin{array}{c}8,125^{* * * *} \\
(0,407)\end{array}$ & $\begin{array}{c}3,247 * * * \\
(0,409)\end{array}$ \\
\hline Korrigált $\mathbf{R}^{2}$ & 0,256 & 0,201 & 0,258 & 0,330 & 0,316 \\
\hline
\end{tabular}

Megjegyzés: a zárójelben szereplö számok sztenderd hibák. Referencia kategóriák: nö, 30 évtôl fiatalabb, falu+község+tanya, 8 általános vagy kevesebb, egyedülálló, nem dolgozik, nem jönnek ki a havi bevételeikböl (nehezen+nagyon nehezen élnek meg), rossz szubjektiv egészség (rossz+nagyon rossz), nincs biztonságérzete (nem+egyáltalán nem biztonságos), pesszimista. Hiányzó esetek kezelése: pairwise, ezért a változópáronként eltérö $N$-ek itt nem kerülnek közlésre. Szignifikancia szintek: ${ }^{*} p<0.10,{ }^{* *} p<0.05,{ }^{* *} p<0.01$ 
13. táblázat: A szubjektív életminőség öt fö összetevőjének (having, loving, being, boldogság, érzelmi balansz) integrált regressziós modelljei, 2012, OLS (sztenderdizálatlan regressziós együtthatók, szignifikancia szintek)

\begin{tabular}{|c|c|c|c|c|c|}
\hline & Having & Loving & Being & Boldogság & Balansz \\
\hline Férfi & $\begin{array}{l}-0,048 \\
(0,112)\end{array}$ & $\begin{array}{l}-0,072 \\
(0,060)\end{array}$ & $\begin{array}{l}-0,011 \\
(0,044)\end{array}$ & $\begin{array}{c}-0,169 * \\
(0,100)\end{array}$ & $\begin{array}{c}0,260 * * \\
(0,101)\end{array}$ \\
\hline Életkor: 30-39 éves & $\begin{array}{c}-\mathbf{0 , 6 1 7} * * * \\
(0,191)\end{array}$ & $\begin{array}{c}-0,229 * * \\
(0,103)\end{array}$ & $\begin{array}{l}0,146^{*} \\
(0,075)\end{array}$ & $\begin{array}{c}-\mathbf{0 , 3 7 9} * * \\
(0,170)\end{array}$ & $\begin{array}{l}-0,216 \\
(0,173)\end{array}$ \\
\hline 40-49 éves & $\begin{array}{c}-0,697 * * * * \\
(0,190)\end{array}$ & $\begin{array}{c}-\mathbf{- 0 , 2 2 4} * * \\
(0,102)\end{array}$ & $\begin{array}{c}0,172 * * \\
(0,074)\end{array}$ & $\begin{array}{c}-\mathbf{0 , 5 7 0} * * * * \\
(0,169)\end{array}$ & $\begin{array}{c}-\mathbf{- 0 , 3 7 5} * * \\
(0,172)\end{array}$ \\
\hline 50-59 éves & $\begin{array}{c}-0,666 * * * * \\
(0,194)\end{array}$ & $\begin{array}{l}-0,135 \\
(0,104)\end{array}$ & $\begin{array}{c}0,314 * * * \\
(0,076)\end{array}$ & $\begin{array}{c}-0,636 * * * \\
(0,173)\end{array}$ & $\begin{array}{c}-0,565 * * * \\
(0,175)\end{array}$ \\
\hline 60-69 éves & $\begin{array}{c}-0,450 * * \\
(0,211)\end{array}$ & $\begin{array}{c}-0,242 * * \\
(0,113)\end{array}$ & $\begin{array}{c}0,275 * * * \\
(0,083)\end{array}$ & $\begin{array}{c}-0,754 * * * \\
(0,188)\end{array}$ & $\begin{array}{c}-0,584 * * \\
(0,191)\end{array}$ \\
\hline 70 éves vagy idősebb & $\begin{array}{l}-0,034 \\
(0,222)\end{array}$ & $\begin{array}{l}-0,103 \\
(0,119)\end{array}$ & $\begin{array}{c}0,116 \\
(0,087)\end{array}$ & $\begin{array}{c}-0,612 * * \\
(0,198)\end{array}$ & $\begin{array}{l}-0,440 * * \\
(0,200)\end{array}$ \\
\hline Nagyváros és elővárosa & $\begin{array}{c}0,179 \\
(0,149)\end{array}$ & $\begin{array}{c}-0,162 * * \\
(0,080)\end{array}$ & $\begin{array}{l}-0,094 \\
(0,058)\end{array}$ & $\begin{array}{r}-0,228 * \\
(0,133)\end{array}$ & $\begin{array}{c}0,089 \\
(0,134)\end{array}$ \\
\hline Város vagy kisváros & $\begin{array}{c}0,080 \\
(0,130)\end{array}$ & $\begin{array}{c}-0,023 \\
(0,070)\end{array}$ & $\begin{array}{l}-0,038 \\
(0,051)\end{array}$ & $\begin{array}{l}-0,161 \\
(0,116)\end{array}$ & $\begin{array}{l}-0,124 \\
(0,117)\end{array}$ \\
\hline Szakmunkás/szakiskola & $\begin{array}{l}-0,115 \\
(0,148)\end{array}$ & $\begin{array}{l}-0,003 \\
(0,080)\end{array}$ & $\begin{array}{l}0,120 * * \\
(0,058)\end{array}$ & $\begin{array}{l}-0,034 \\
(0,132)\end{array}$ & $\begin{array}{c}0,114 \\
(0,134)\end{array}$ \\
\hline Érettségi & $\begin{array}{l}-0,215 \\
(0,155)\end{array}$ & $\begin{array}{c}\mathbf{0 , 1 6 3 * *} \\
(\mathbf{0 , 0 8 3 )}\end{array}$ & $\begin{array}{c}0,061 \\
(0,061)\end{array}$ & $\begin{array}{l}-0,069 \\
(0,138)\end{array}$ & $\begin{array}{l}-0,062 \\
(0,140)\end{array}$ \\
\hline Felsőfokú & $\begin{array}{c}0,260 \\
(0,190)\end{array}$ & $\begin{array}{c}0,155 \\
(0,102)\end{array}$ & $\begin{array}{c}0,235 * * \\
(0,074)\end{array}$ & $\begin{array}{c}0,115 \\
(0,169)\end{array}$ & $\begin{array}{c}0,145 \\
(0,171)\end{array}$ \\
\hline $\begin{array}{l}\text { Egy före jutó havi nettó } \\
\text { háztartási jövedelem }\end{array}$ & $\begin{array}{l}4,655 \mathrm{E}-6^{* * *} \\
(0,000)\end{array}$ & $\begin{array}{c}3,591 \mathrm{E}-8 \\
(0,000)\end{array}$ & $\begin{array}{c}-1,023 \mathrm{E}-6^{*} \\
(0,000)\end{array}$ & $\begin{array}{l}3,037 \mathrm{E}-6 * * \\
(0,000)\end{array}$ & $\begin{array}{l}4,465 \mathrm{E}-6^{* * *} \\
(0,000)\end{array}$ \\
\hline Házas/élettárssal él & $\begin{array}{c}0,052 \\
(0,123)\end{array}$ & $\begin{array}{c}0,090 \\
(0,066)\end{array}$ & $\begin{array}{l}-0,016 \\
(0,048)\end{array}$ & $\begin{array}{c}0,419 * * * \\
(0,109)\end{array}$ & $\begin{array}{c}0,125 \\
(0,111)\end{array}$ \\
\hline Dolgozik & $\begin{array}{c}0,003 \\
(0,144) \\
\end{array}$ & $\begin{array}{l}-0,012 \\
(0,077)\end{array}$ & $\begin{array}{c}0,126 * * \\
(0,056) \\
\end{array}$ & $\begin{array}{l}-0,095 \\
(0,128) \\
\end{array}$ & $\begin{array}{l}-0,057 \\
(0,130) \\
\end{array}$ \\
\hline $\begin{array}{l}\text { Kijönnek a havi } \\
\text { bevételeikből }\end{array}$ & $\begin{array}{c}0,926 * * * \\
(0,126)\end{array}$ & $\begin{array}{l}0,177 * * \\
(0,068)\end{array}$ & $\begin{array}{c}0,098 * * \\
(0,049)\end{array}$ & $\begin{array}{c}0,731 * * * \\
(0,112)\end{array}$ & $\begin{array}{c}0,499 * * * \\
(0,114)\end{array}$ \\
\hline Jó szubjektív egészség & $\begin{array}{c}0,651 * * * \\
(0,181)\end{array}$ & $\begin{array}{l}-0,009 \\
(0,097)\end{array}$ & $\begin{array}{l}0,216 * * \\
(0,071)\end{array}$ & $\begin{array}{c}0,695 * * * \\
(0,161)\end{array}$ & $\begin{array}{c}1,228 * * * \\
(0,164)\end{array}$ \\
\hline Van biztonságérzete & $\begin{array}{c}0,165 \\
(0,125)\end{array}$ & $\begin{array}{l}-0,050 \\
(0,067)\end{array}$ & $\begin{array}{l}-0,045 \\
(0,049)\end{array}$ & $\begin{array}{c}0,036 \\
(0,112)\end{array}$ & $\begin{array}{l}0,206 * \\
(0,113)\end{array}$ \\
\hline $\begin{array}{l}\text { Anómia és } \\
\text { elidegenedésérzet }\end{array}$ & $\begin{array}{c}-0,236 * * * \\
(0,022)\end{array}$ & $\begin{array}{c}-0,202 * * * \\
(0,012)\end{array}$ & $\begin{array}{c}-0,143 * * * \\
(0,009)\end{array}$ & $\begin{array}{c}-0,284 * * * \\
(0,020)\end{array}$ & $\begin{array}{c}-\mathbf{0 , 3 1 0} \text { **** } \\
(\mathbf{0 , 0 2 0})\end{array}$ \\
\hline Optimista & $\begin{array}{l}\mathbf{0 , 8 5 0} * * * \\
(\mathbf{0 , 1 1 9 )}\end{array}$ & $\begin{array}{c}0,083 \\
(0,064)\end{array}$ & $\begin{array}{c}0,269 * * * \\
(0,047)\end{array}$ & $\begin{array}{c}0,787 * * * \\
(0,106)\end{array}$ & $\begin{array}{c}0,741 * * * \\
(0,107)\end{array}$ \\
\hline Konstans (B) & $\begin{array}{c}6,380 * * * \\
(0,354)\end{array}$ & $\begin{array}{c}7,981^{* * * *} \\
(0,190)\end{array}$ & $\begin{array}{c}4,597 * * * \\
(0,139)\end{array}$ & $\begin{array}{c}7,772 * * * \\
(0,315)\end{array}$ & $\begin{array}{c}2,501 * * * \\
(0,320)\end{array}$ \\
\hline Korrigált $\mathbf{R}^{2}$ & 0,310 & 0,262 & 0,310 & 0,364 & 0,390 \\
\hline
\end{tabular}

Megjegyzés: a zárójelben szereplö számok sztenderd hibák. Referencia kategóriák: ugyanazok, mint a 12. táblázat esetében. Hiányzó esetek: pairwise. Szignifikancia szintek: ${ }^{*} p<0.10, * * p<0.05, * * * p<0.01$ 
Összességében, a két időszak eredményeinek áttekintése alapján annyi állapítható meg, összhangban a kutatási előzményekkel, hogy egyrészt a nem és a településtípus változók alapvetően kis mértékben befolyásolják a szubjektív életminőség having, loving, being, boldogság, és érzelmi egyenleg dimenzióinak alakulását. A jobb jövedelmi körülmények kedvezőbb realizációs szinttel járnak együtt a having dimenzió esetében. A házasság egyéni jóllétre kifejtett kedvező hatását (Diener et al., 1999) a boldogság skála egyértelműen mérte, jóllehet az átlagos indexértékváltozás 2012-re valamelyest lecsökkent (2006: B 0,592 $(0,135), \mathrm{p}<0,01 ; 2012$ : B 0,419 $(0,109), \mathrm{p}<0,01)$, azonban a két együttható közötti eltérés (tehát a különbség) szignifikanciáját itt nem vizsgáltuk. Továbbá, az egyéni anómia- és elidegenedésérzet és az optimista szemléletmód szignifikánsan befolyásolták az öt jóllétdimenzió alakulását, míg az előbbi negatív, az utóbbi pozitív kapcsolatban állt az alskálákkal. Azok az egyének, akik úgy értékelték, hogy kijönnek a jelenlegi bevételeikből, az általános egészségüket jónak értékelték, és a lakókörnyékükön biztonságban érzték magukat, jellemzően az életminőség emocionális indikátoraival mutattak pozitív összefüggést. Azonban arra a kérdésre, hogy a társadalmi-demográfiai csoportok közötti alskálák alapján mért átlagos különbségek az egyes dichotóm társadalmi csoportok multidimenzionális indikátorral mért szubjektív életminőségében mutatnak-e majd szignifikáns különbségeket a két időszak összevetésében, az összevont adatokon elkészített többváltozós elemzések konfirmálják.

\subsection{A szubjektív életminőség alakulása az eltérő társadalmi- demográfiai csoportokban}

A következő részben az öt dimenzió összetett indikátora által együttesen mért többdimenziós szubjektív életminőség alakulását, annak fő tendenciáit vizsgáljuk meg a főbb társadalmi-demográfiai csoportokban a magyar lakosság körében.15 (A kapcsolódó, dichotóm, illetve folytonos változókra elkészített diagramokat az F. 14. sz. Függelék tartalmazza.)

A többdimenziós szubjektív életminőség alakulását vizsgálva

15 A multidimenzionális szubjektív életminőség alakulását a lakossági átlaghoz mért eltérések alapján vizsgáljuk meg a két évben. Az eltérések, egy-egy esettől eltekintve, 1\%-os szinten szignifikánsak (lásd: Mellékelt). 
megállapíthattuk, hogy az életkori korcsoportok szerint 2006-ban a 30 év alattiak számoltak be az átlagtól magasabb életminőségről, azonban 2012-ben a fiatalok mellett a 30-39 éves korcsoporthoz tartozó fiatal felnőttek is az átlagtól pozitívabban értékelték életminőségüket. A válság előtt az átlagostól kedvezőtlenebb értékelést az idősebb generációkhoz tartozók, de közülük is elsősorban az 50-59 évesek adtak. Azonban a válságot követően a 70 évtől idősebbek voltak azok, akik a legkedvezőtlenebb életminőségről adtak számot (8.a-b. ábrák).

8. a. ábra: A Szubjektív Életminőség Index és az életkori korcsoportok kapcsolata, $2006\left(Z\right.$-score átlag $\left.{ }^{16}\right)(\mathrm{N}=1427)$

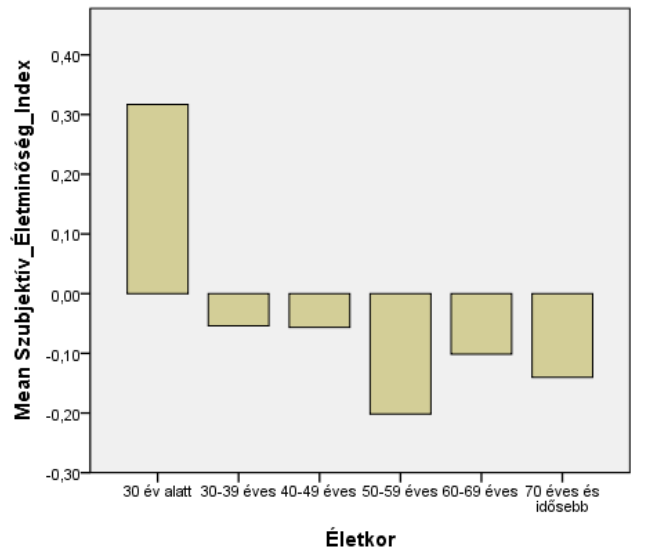

8. b. ábra: A Szubjektív Életminőség Index és az életkori korcsoportok kapcsolata, 2012 (Z-score átlag) $(\mathrm{N}=1905)$

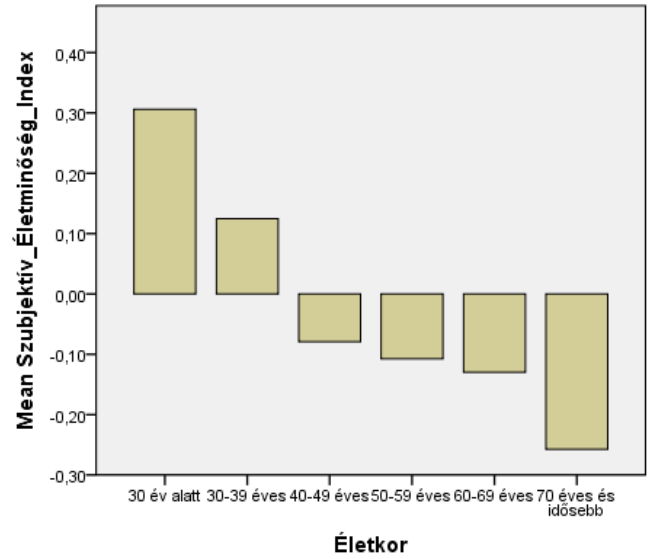

16 A Z-score standardizált mérőszám azt mutatja meg, hogy adott változó populációbeli átlagától (0) hány szórásra térnek el az egyes független változókategóriákban mért indexértékek. A pozitív irányú eltérés a lakossági átlagtól kedvezőbb, a negatív irányú eltérés kedvezőtlenebb szubjektív életminőséget jelent. 
Az iskolai végzettség szerinti csoportokat megvizsgálva azt láttuk, hogy a válság előtt a diplomások és az érettségizettek értek el átlagostól magasabb életminőséget, míg a válság után a felsőfokú végzettségűek adtak kedvezőbb, a szakmunkás, szakiskolát végzettek kevésbé kedvezőtlen értékelést. Az alacsony iskolai végzettségüek átlagoshoz viszonyított szubjektív életminősége a legkedvezőtlenebb, mely nem változott az időben (9. a-b. ábrák).

9. a. ábra: A Szubjektív Életminőség Index és az iskolai végzettség összefüggése, 2006 (Z-score átlag) $(\mathrm{N}=1431)$

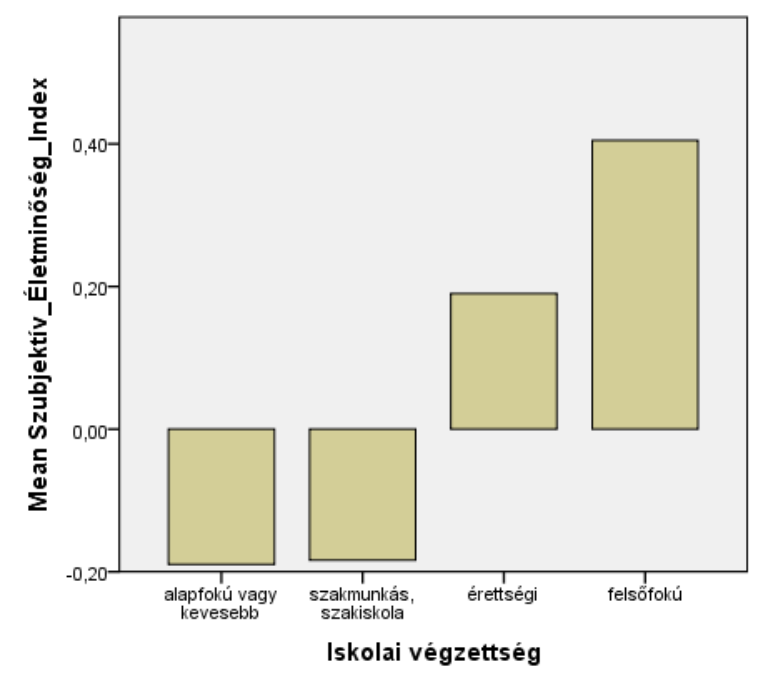

9. b. ábra: A Szubjektív Életminőség Index és az iskolai végzettség összefüggése, 2012 (Z-score átlag) $(\mathrm{N}=1901)$

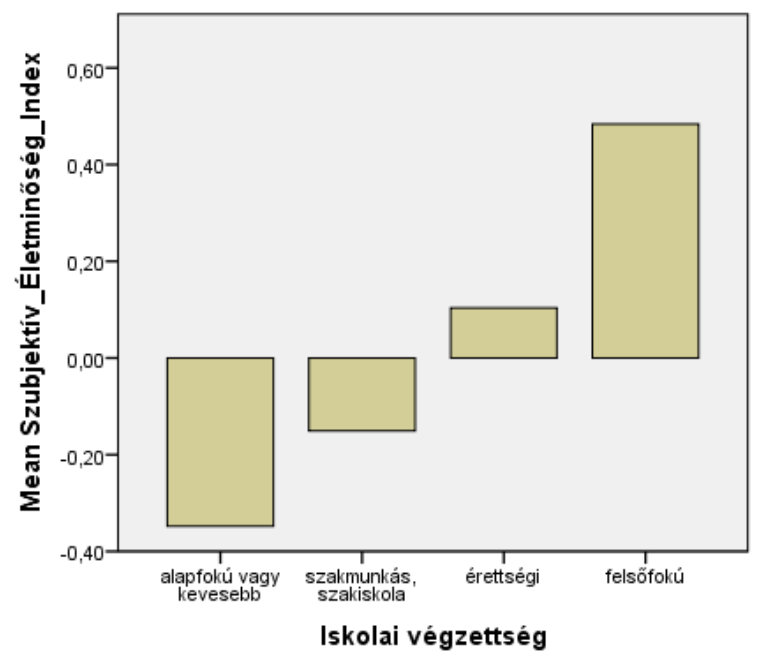

A családi státusz alapján az eredmények azt mutatták, hogy a recesszió előtt és azt követően is a házasok vagy élettárssal élők, illetve a nőtlenek és hajadonok 
értékelték az átlagostól magasabb pontszámmal életminőségüket. Az elváltak, és akiknek élettársi kapcsolatuk felbomlott, illetve az özvegyek és azok, akiknek élettársuk elhunyt, hasonlóan a társadalmi átlagtól rosszabb életminőségről adtak számot (10. a-b. ábrák).

10. a. ábra: A Szubjektív Életminőség Index és a családi állapot kapcsolata, 2006 (Zscore átlag) $(\mathrm{N}=1429)$

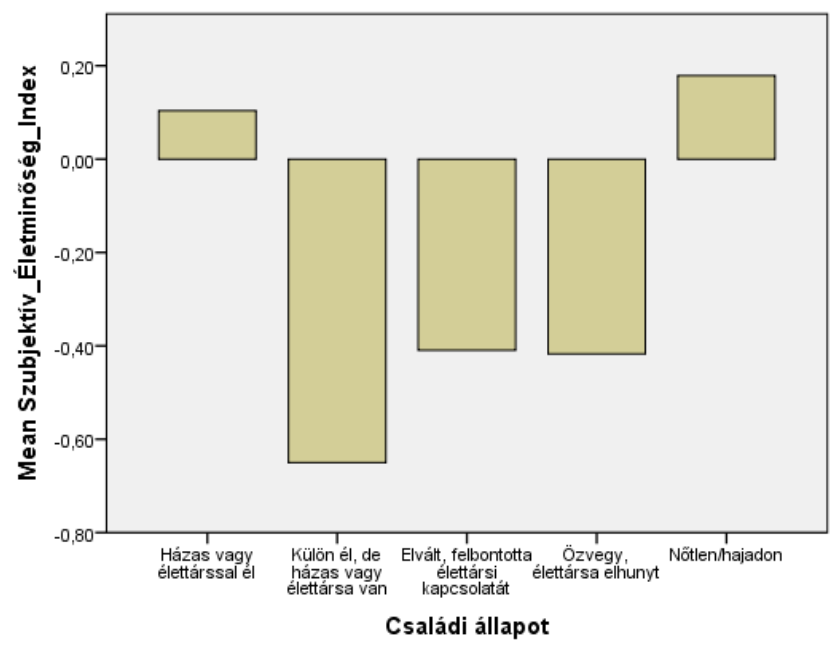

10. b. ábra: A Szubjektív Életminőség Index és a családi állapot kapcsolata, 2012 (Zscore átlag) $(\mathrm{N}=1863)$

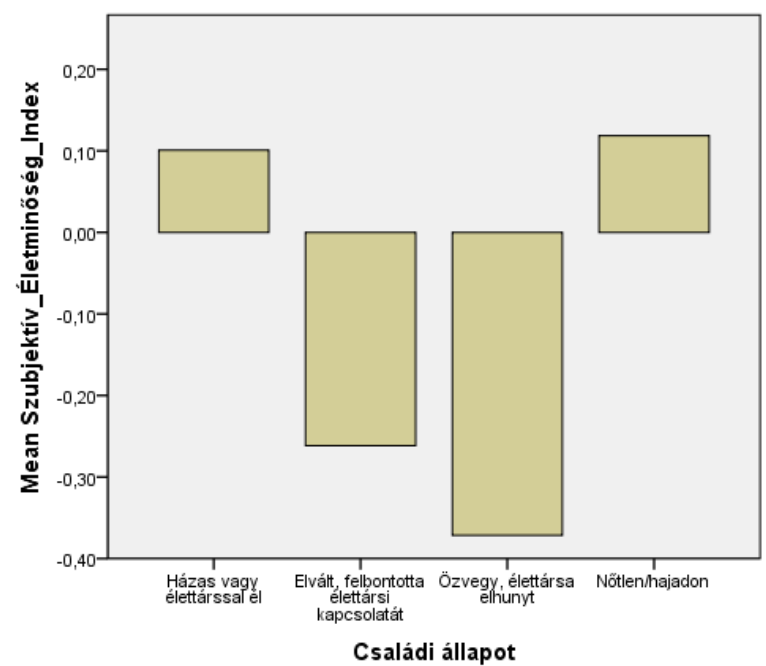

Azonban ezen utóbbi csoportokhoz képest is kedvezőtlenebb életminőséget értek el azok az egyének, akik jogilag házasok voltak, vagy törvényes élettársi kapcsolatuk 
volt, de különéltek. (Ez a kategória 2012-ben nem került Magyarországon felvételre.) Összességében az egyedülállók multidimenzionális életminőség indexen elért átlagpontszáma átlagtól kedvezőtlenebb, a házasok, élettárssal élőké pedig átlagostól kedvezőbb mindkét időszakban. Jóllehet az egyedülállók között a nőtlenek és a hajadonok e csoport értékelését javították.

Az előző héten jellemzően végzett tevékenység alapján a diákok voltak azok, akik az átlagtól jóval kedvezőbb életminőségről számoltak be a válság előtt és azt követően is. Azok, akik jelen voltak a munkaerőpiacon, mind 2006-ban, mind 2012ben a lakosság átlagos jóllétének a színvonalát közelítették meg. A nyugdíjasoknak, a munkanélkülieknek és a tartósan betegeknek vagy rokkantaknak mindkét időszakban az átlagostól kedvezőtlenebb volt a szubjektív életminősége, azonban a válság utáni években a tartósan betegek és rokkantak életminősége romló tendenciát jeleztett (11. a-b. ábrák).

11. a. ábra: A Szubjektív Életminőség Index és az elmúlt héten végzett jellemző tevékenység (foglalkozás) összefüggése, 2006 (Z-score átlag) (N=1308)

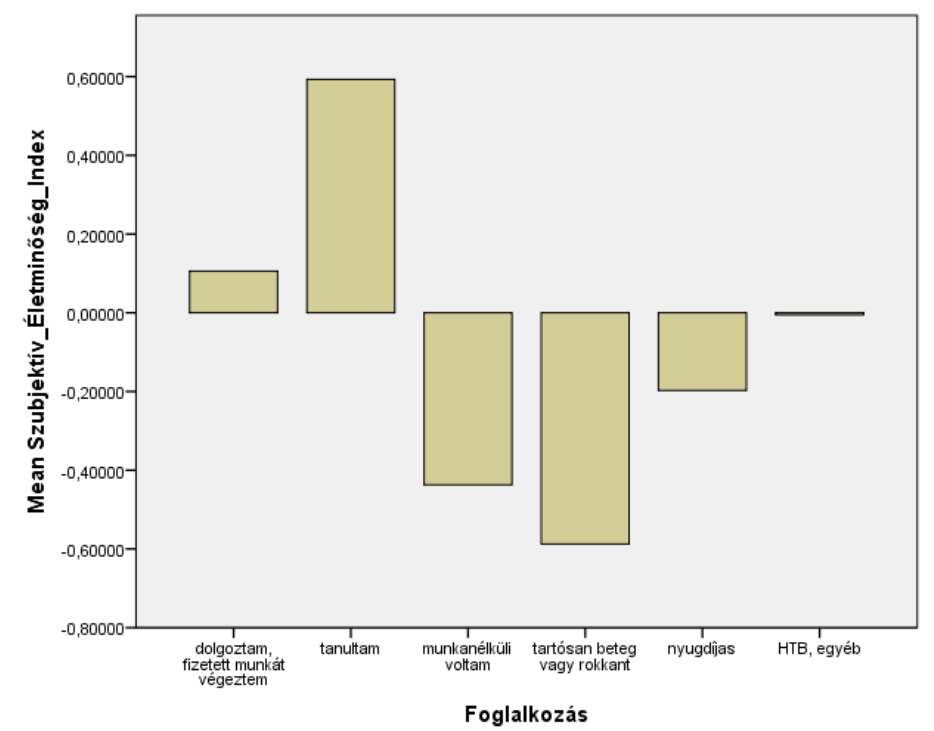


11. b. ábra: A Szubjektív Életminőség Index és az elmúlt héten végzett jellemző tevékenység (foglalkozás) összefüggése, 2012 (Z-score átlag) (N=1888)

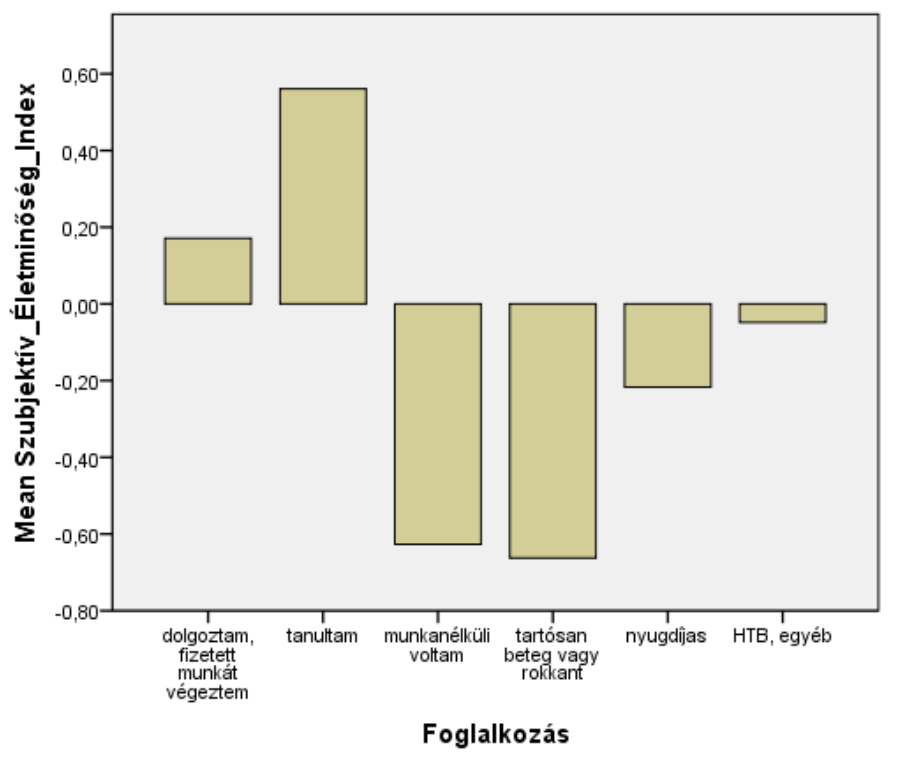

A hazai és a külföldi szakirodalomból ismert összefüggés, mely szerint a magasabb jövedelem kedvezőbb egyéni jólléttel jár együtt, jelen elemzés során is igazolódott, a két változó között gyenge pozitív lineáris kapcsolatot találtunk, melyről a Függelék F.10.2. a.-b. sz. ábrái tájékoztatnak. Az egéni anómiát és elidegenedést mérő skála erős negatív irányú kapcsolatot mutatott a szubjektív életminőség indikátorával, tehát minél inkább magányosnak, elszigeteltnek érzi magát valaki, és minél inkább értelmetlennek és haszontalannak érzékeli az életét, annál kedvezőtlenebb lesz a szubjektív életminősége (lásd a Függelék F.10.3. a.-b. ábráit). Az egészségi állapot szubjektív értékelése alapján azok, akik kedvezőbb egészségi állapotról adtak számot, a lakossági átlagtól kedvezőbb életminőséget értek el, mind a válság előtt, mind azt követően. Azok pedig, akik 'rossz' vagy 'nagyon rossz' kategóriát választottak általános egészségi állapotuk leírására, mindkét évben jelentősen a társadalmi átlag alatti pontszámmal jellemezhetőek az életminőség index alapján (12. a-b. ábrák). (A többváltozós elemzésekhez használt dichotóm egészségi állapot indikátor megoszlását a Függelék F.10.4. a-b. ábrái mutatják be.) 
12. a. ábra: A Szubjektív Életminőség Index és a szubjektív egészségi állapot kapcsolata, 2006 (Z-score átlag) $(\mathrm{N}=1432)$

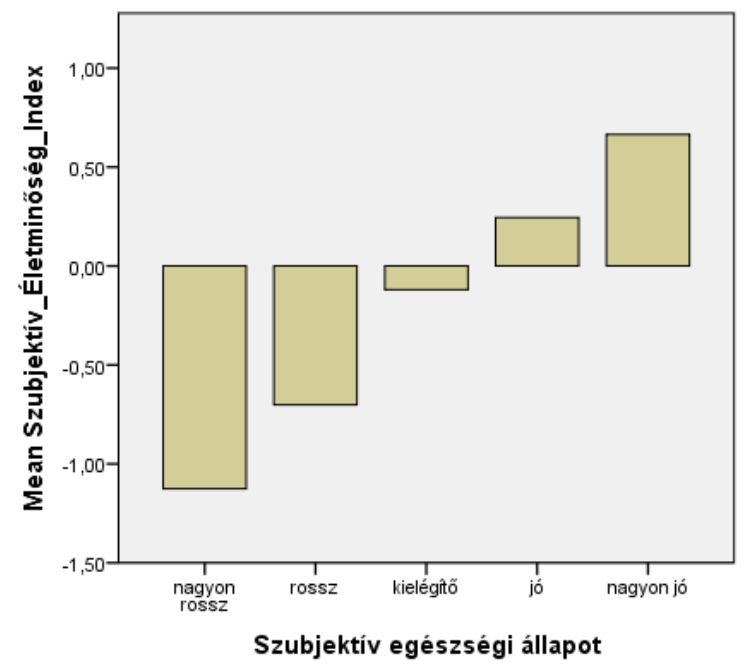

12. b. ábra: A Szubjektív Életminőség Index és a szubjektív egészségi állapot kapcsolata, 2012 (Z-score átlag) $(\mathrm{N}=1905)$

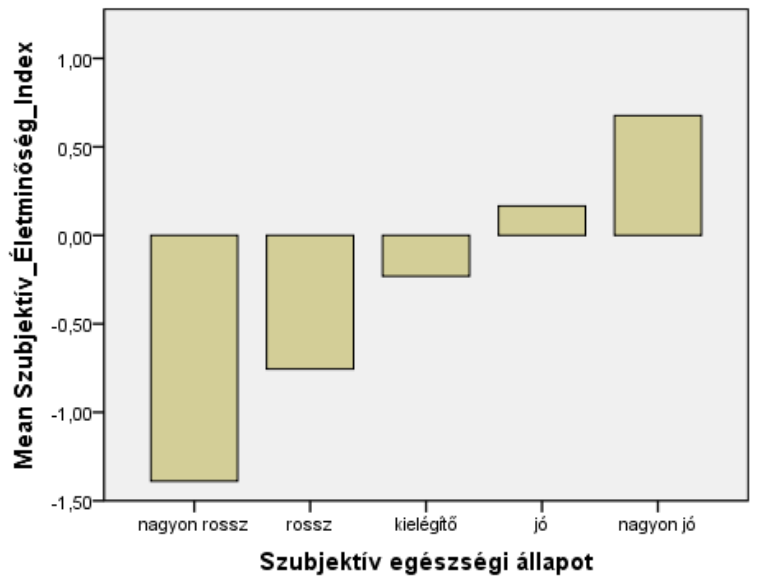

A lakókörnyékhez kapcsolódó biztonságérzet és a szubjektív életminőség kapcsolata mindkét évben hasonló mintázatot mutat, azok számoltak be társadalmi átlagtól kedvezőbb életminőségről, és értek el kedvezőbb indexértékeket, akik úgy érezték, hogy lakókörnyékük nagyon biztonságos. Az átlaghoz képest legalacsonyabb pontértéket azoknak a körében mértünk, akik úgy értékelték, hogy a lakókörnyékük este sötétedés után 'egyáltalán nem biztonságos'. Az összefüggéseket a 13. a-b. ábrák mutatják be. (A többváltozós elemzéseknél alkalmazott dichotóm szubjektív biztonságérzet mutató megoszlásait a Függelék F.10.5. a-b. ábrái tartalmazzák. ) 
13. a. ábra: A Szubjektív Életminőség Index és a lakókörnyékhez kapcsolódó biztonságérzet összefüggése, 2006 (Z-score átlag) (N=1419)

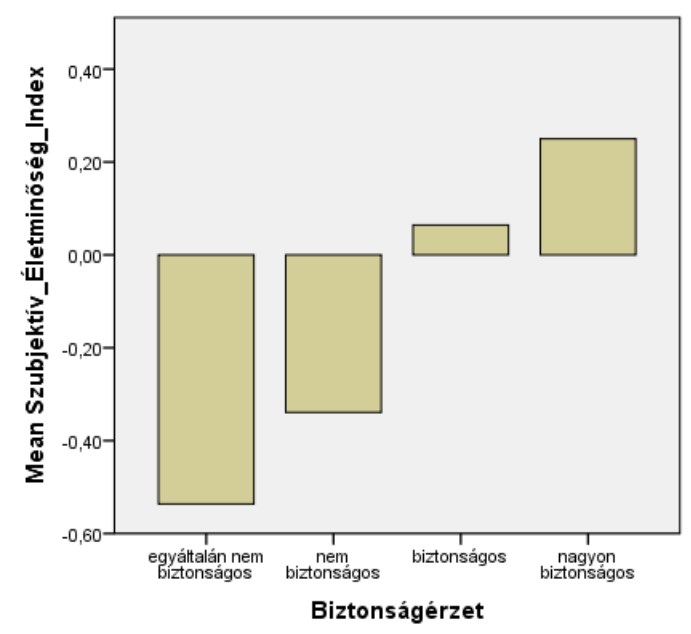

13. b. ábra: A Szubjektív Életminőség Index és a lakókörnyékhez kapcsolódó biztonságérzet összefüggése, 2012 (Z-score átlag) $(\mathrm{N}=1871)$

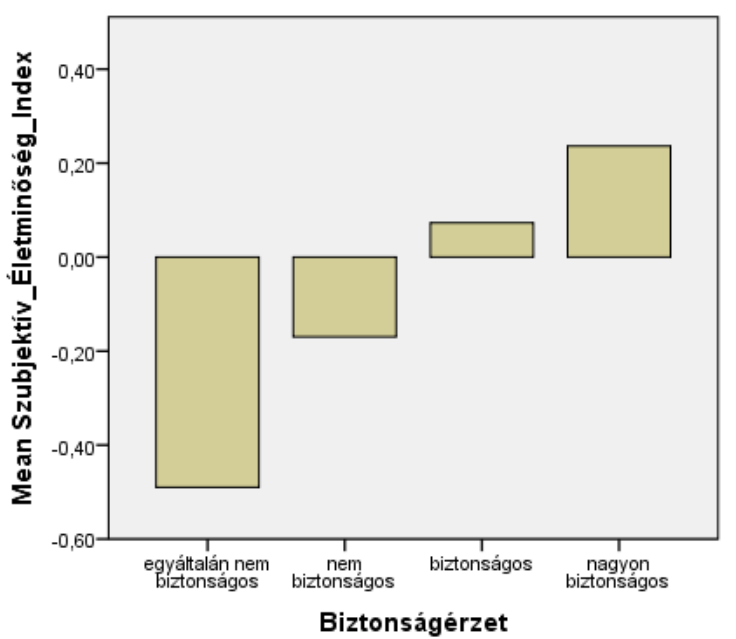

A mindennapi anyagi problémák léte vagy hiánya, a megélhetési gondok és az azokra adott egyéni problémakezelési megoldások meghatározzák az egyén szubjektív jövedelmi helyzetének értékelését, melyek mindig pozitív összefüggést mutattak az individuális jólléttel a szakirodalomban (Hank-Wagner, 2013; Siposné, 2016). Azok, akik úgy érezték, hogy könnyebben megküzdenek a válság következményeiként rájuk háruló anyagi terhekkel, kedvezőbb életminsőéget érhettek el a recesszió éveiben is (14. a-b. ábrák). 
14. a. ábra: A szubjektív életminőség alakulása a jövedelmi helyzet szubjektív értékelése függvényében, 2006 ( $Z$-score átlag) $(\mathrm{N}=1424)$

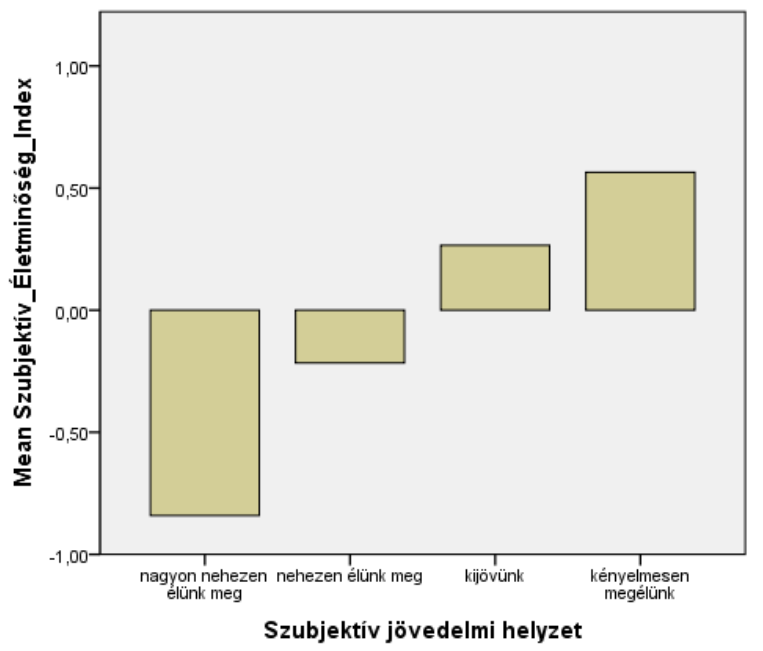

14. b. ábra: A szubjektív életminőség alakulása a jövedelmi helyzet szubjektív értékelése függvényében, 2012 (Z-score átlag) $(\mathrm{N}=1887$ )

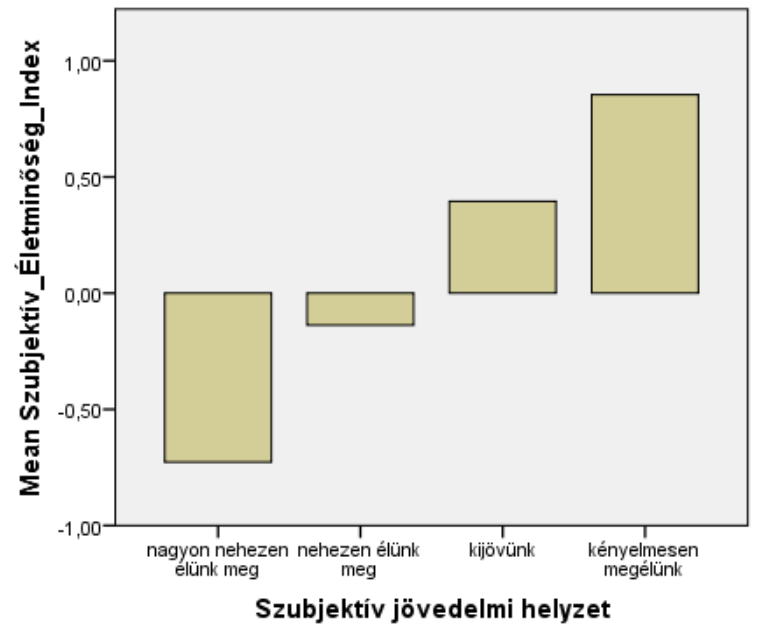

A jövedelmi helyzet szubjektív értékelése alapján látható, hogy akik 'nehezen', vagy 'nagyon nehezen' jönnek ki a rendelkezésükre álló jelenlegi bevételeikből, az átlagtól alacsonyabb életminőségről, míg azok, akik 'kijönnek', vagy 'kényelmesen megélnek', magasabb életminőségről számolnak be, azonban ezen utóbbi csoport értékelésének kedvezőbb tendenciája mutatkozik meg 2012-ben a korábbi időszakhoz képest (15. a-b. ábrák). 
15. a. ábra: A Szubjektív Életminőség Index és a személyes beállítottság kapcsolata, 2006 (Z-score átlag) $(\mathrm{N}=1427)$

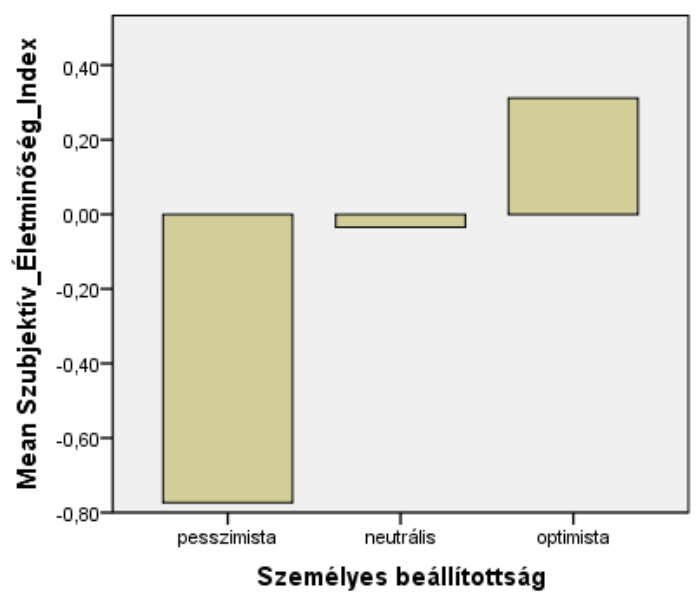

15. b. ábra: A Szubjektív Életminőség Index és a személyes beállítottság kapcsolata, 2012 (Z-score átlag) $(\mathrm{N}=1900)$

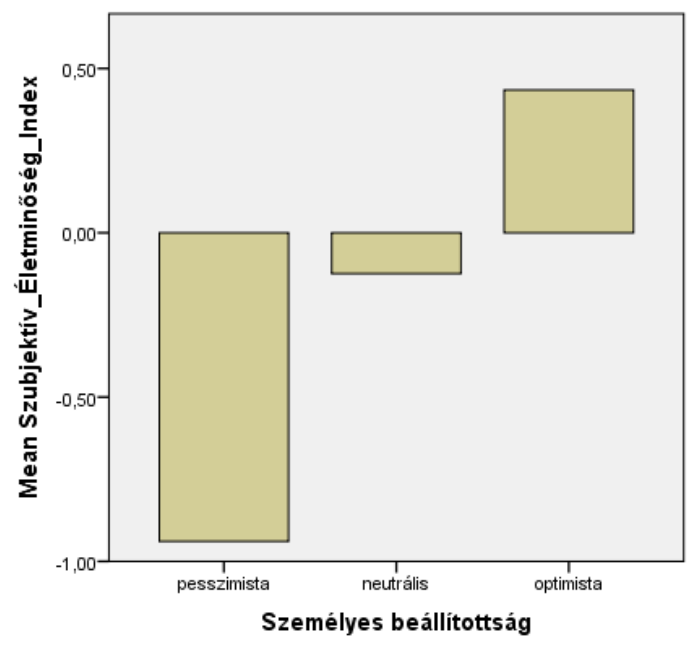

A személyes beállítottságok szignifikáns meghatározói a szubjektív jóllét alakulásának, a szakirodalom szerint az extrovert, optimista jellemvonás pozitív, míg az introvert, pesszimista negatív összefüggést mutatott a korábbi vizsgálatokban (Headey-Wearing, 1989; Diener-Lucas, 1999). Kutatásunkban a pesszimisták átlagtól alacsonyabb, míg a jövőbe bizakodóan tekintők átlagostól kedvezőbb életminőségről adtak számot mindkét időszakban, míg a neutrális attitűd átlagoshoz közeli életminséggel járt együtt.

Összefoglalva a főbb társadalmi-demográfiai csoportok jellemzőit, annyit mondhatunk el, hogy amíg a társadalmi átlagtól kedvezőbb szubjektív 
életminőségüket a 30 év alattiak, a diákok, a felsőfokú végzettségüek és az optimisták a recesszió éveiben is fenn tudták tartani, esetlegesen javítani, addig a sérülékeny társadalmi csoportoknál romló tendencia volt figyelhető, mely az egyes társadalmi nagycsoportok válság évei alatt bekövetkező divregenciáját jelzi előre. Nézzük meg tehát, hogy az előzetes eredmények valóban alátámasztásra kerülnek-e a hipotézisek tesztelése útján.

\subsection{A gazdasági válság hipotézisének vizsgálata}

A kutatás fö hipotézisének tesztelését két lépésben végeztük el. Első lépésben a magyarázó változó és a függő változó kapcsolatának önálló elemzésével, a kontrollváltozók bevonása nélkül. A második lépésben, a magyarázó változó mellett a társadalmi-demográfiai kontrollváltozókat is bevontuk az elemzésbe (nem, életkor, településtípus, iskolai végzettség, egy före jutó havi nettó háztartási jövedelem), hogy a magyarázó változó hatását az összetételbeli hatások torzítása nélkül vizsgálhassuk. A hipotézisek tesztelésének módszere, a korábbi „Adatok és módszerek” fejezetben leírtak szerint a legkisebb négyzetek módszere (OLS), a lineáris regressziós eljárás. A regresszióelemzést a fentiekben leírt lépéseknek megfelelően, hipotézisenként külön-külön, majd a hipotézis-csoportokra együttesen, illetve az elemzés legvégén, az integrált modellben a hipotézisek minden egyes magyarázó változójának és a kontrollváltozóknak a bevonása mellett futtatjuk le $\mathrm{e}^{17}$.

Lényegesnek tartjuk kiemelni, hogy a változók közötti ok-okozati összefüggések irányát nem célja jelen kutatásnak vizsgálni, a kiválasztott statisztikai elemzési módszerek csakis az összefüggéseket, a változók közötti együtt-járások erősségét és irányát, azok szignifikáns voltát mutatják ki. Jóllehet a hipotézisekben feltételezett ok-okozati relációkat fogalmaztunk meg, de ahol a

17 Az eljárás alkalmazása feltételeinek teljesülését [függő-független változó közötti lineáris kapcsolat megléte (linearitás), a változók normális eloszlása (normalitás), a független változók egymás közötti függetlensége (multikollinearitás hiánya), a függő és független változók sztochasztikus kapcsolata (determinisztikus kapcsolat hiánya), a hibatagokra vonatkozó kritériumok: a hibatagok normális eloszlása, a hibatagok korrelálatlansága (heteroszkedaszticitás hiánya)], tehát a statisztikákat lásd a DVD mellékletben. Az egyes kategóriális változók esetében a dummy kódolás során az elemzésből kihagyott kategória szintén a multikollinearitás problémáját hivatott kiküszöbölni. (Az egy före jutó havi nettó háztartási jövedelem és a dichotóm szubjektív jövedelmi helyzet változói között legfeljebb 0,40 erősségű volt a korrelációs együttható értéke.) 
kontrollváltozók bevonása mellet az összefüggés nem volt szignifikáns, abban az esetben a hipotézisben feltételezettek nem igazolódtak. Ahhoz hogy a hipotézisek megálljanak, a kontrollváltozók mellett is szignifikánsnak kell maradni a kapcsolatnak. Továbbá az összefüggések elemzése során gyakran használjuk majd a "hatás” kifejezést, amely azonban nem az oksági kapcsolatoknál bevett értelemben jelenik meg a fentieknek megfelelően.

A hipotézisek teszteléséhez mindkét évben egy-egy szummatív skála került kialakításra, ugyanazon értéktartománnyal rendelkező, egyező irányba forgatott ugyanazon öt alskálával, mint amelyeket az eredeti indexnél alkalmaztunk (having, loving, being, boldogság, pozitív-negatív balansz). A szummatív skálán, mely 0-tól 36-ig terjedően vett fel értékeket, a magasabb pontok kedvezőbb szubjektív életminőséget jelentettek. ${ }^{18}$

Az összevont keresztmetszeti adatokon elvégzett regressziós elemzések alapján, az I. modell esetében - melyet kizárólag az idő-dummy változóra futtatunk le -, látható, hogy a lakosság szubjektív életminőség indexen elért átlagos pontszáma -0,623 egységnyi értékkel csökkent 2012-re, mely összefüggés szignifikáns (14. sz. táblázat). A bevezetőben leírt tapasztalati tényeknek és az általános intuíciónknak ezek az eredmények alapvetően megfelelnek. Kérdés azonban az, hogy ezt a kapcsolatot a társadalmidemográfiai tényezők alátámasztják-e?

A II. modellben, a kontrollváltozók bevonását követően a 2012-es év együtthatója már nem mutat szignifikáns kapcsolatot. Vagyis a társadalmidemográfiai tényezők azonos szinten tartása mellett, tehát ugyanolyan életkorú, nemű, iskolai végzettségü és jövedelmi helyzetű, azonos településtípuson élő egyén szubjektív életminősége nem különbözik szignifikánsan a két időszak összehasonlításának eredményeképpen. Tehát a hipotézist el kell vetnünk, így azt állapíthatjuk meg, hogy 2006-hoz viszonyítva 2012-ben, az összetételi hatások kiszürése mellett a lakosság szubjektív életminősége szignifikánsan nem csökkent.

18 A skála megbízhatósági statisztikák szignifikánsak, melyek Cronbach Alfa értékei megfelelően magasak mindkét évben: 2006: 0,768; 2012: 0,781. 
14. táblázat: A gazdasági válság hipotézisének a szubjektív életminőség mértékével kapcsolatos regressziós modelljei, összevont keresztmetszeti adatok, OLS (sztenderdizálatlan regressziós együtthatók, szignifikancia szintek)

\begin{tabular}{|c|c|c|}
\hline & I. modell & II. modell \\
\hline Év: 2012 & $-0,623 * * *(0,237)$ & $0,215(0,297)$ \\
\hline Férfi & & $-0,151(261)$ \\
\hline 30-39 éves & & $-2,325 * * *(0,425)$ \\
\hline 40-49 éves & & $-3,228 * * *(0,412)$ \\
\hline 50-59 éves & & $-3,441 * * *(0,412)$ \\
\hline 60-69 éves & & $-3,016^{* * * *}(0,444)$ \\
\hline 70 éves és idősebb & & $-3,589 * * *(0,449)$ \\
\hline Nagyváros & & $-0,358(0,344)$ \\
\hline Város & & $-0,219(0,291)$ \\
\hline Szakmunkás & & $0,326(0,336)$ \\
\hline Érettségi & & $2,022 * * *(0,352)$ \\
\hline Felsőfokú & & $4,165 * * *(0,428)$ \\
\hline $\begin{array}{l}\text { Egy före jutó havi nettó } \\
\text { háztartási jövedelem }\end{array}$ & & $1,551 \mathrm{E}-5^{* * *}(0,000)$ \\
\hline Konstans (B) & $21,579 * * *(0,180)$ & $20,841 * * * *(0,481)$ \\
\hline $\mathbf{N}$ & 3356 & 2539 \\
\hline Korrigált $\mathbf{R}^{2}$ & 0,002 & 0,118 \\
\hline
\end{tabular}

Megjegyzés: zárójelben a sztenderd hibák. Referencia kategóriák: 2006, nö, 30 évtöl fiatalabb, Falu+község+tanya, 8 általános vagy kevesebb. Hiányzó esetek kezelése: listwise. Szignifikancia szintek: $* p<0.10, * * p<0.05, * * * p<0.01$

Visszatérve tehát az első magyarázó mechanizmusra, azt állapíthatjuk meg, hogy a válság szubjektív életminőségre kifejtett feltételezett kedvezőtlen hatása, mint periódushatás 2012-ben már nem érvényesült. Ugyanakkor az általános összefüggések igazolást nyertek, a lakosság szubjektív életminőségét a nem és a településtípus szignifikánsan nem befolyásolták. A demográfiai változók esetében a 30 évtől fiatalabbakhoz képest minden életkori korcsoport kedvezőtlenebb életminőséget ért el. A magasabb iskolai végzettség magasabb életminőséggel járt együtt, azonban a szakmunkás végzettség nem tért el szignifikánsan a referencia kategóriától. A jövedelem és a szubjektív életminőség pozitív kapcsolata szintén megerősítést nyert. A II. modell magyarázott variancia értéke $11,8 \%$, tehát látjuk, hogy az objektív változók kis mértékben magyarázzák a szubejktív életminőséget. 


\subsection{A társadalmi integráció hipotéziseinek vizsgálata}

A társadalmi integráció mértékének és a szubjektív életminőség összefüggéseinek a kilábalás éveiben bekövetkezett változásait a családi állapot (házas vagy élettársi kapcsolatban él/egyedülálló) és a munkaerőpiaci jelenlét (dolgozik/nem dolgozik) dichotóm magyarázó változóival vizsgáltuk meg. A magyar társadalom demográfiai jellemzői alapján láttuk, hogy a 15 éves és idősebb népesség családi állapot szerinti jellemzői mentén (nőtlen/hajadon, házas, özvegy, elvált) a házasok aránya a '80-as évektől folyamatosan csökkent napjainkig, míg ezzel párhuzamosan az egyedülállók aránya folyamatosan emelkedett. Az adatok alapján 2006-ban a felnőtt népesség 48.7, míg 2012-ben 44.1 százaléka volt házas, mely tény alátámasztja a két mintában a két év közötti megoszlásbeli eltérést. ${ }^{19}$ Kutatásunkban ugyanakkor a törvényes élettársi kapcsolatban élöket is figyelembe vettük a házasoknál, és ennek megfelelöen alakítottuk ki a házas-nem házas dichotóm kategóriákat. A munkaerő-piaci jelenlét alapján a megoszlás a nem dolgozók nagycsoportján belül mutatott kisebb átrendeződést a két év (2006 és 2012) viszonylatában (rendre, diák: 7.6, 8.5\%; munkanélküli: 4.7, 8.2; tartós beteg/rokkant: 3.9, 3.4; nyugdíjas: 28.4, 26.7; htb/egyéb: 10.0, 6.7), amit természetesen a válság következtében megnövekedett munkanélküliségi adatok támasztanak alá. Azonban a kutatás számára kialakított dichotóm (dolgozik-nem dolgozik) kategória esetében a dolgozók megoszlása a két mintában közel azonos volt (rendre: 45.4, 46.5\%).

A vizsgálat további hipotéziseinek tesztelését három lépésben végztük el. Első lépésben az empirikus teszteket az adott hipotézisekre vonatkozó magyarázó változók és a függő változó kapcsolatának önálló elemzésével, majd második lépésben az adott hipotézisekhez bevont magyarázó változók csoportjának együttes elemzése útján készítettük el a kontrollváltozók bevonása nélkül, hogy a változócsoport hatását együttesen is megvizsgálhassuk (Ezeket az eredményeket a Melléklet tartalmazza.). Ezt követően a harmadik lépésben, a hipotézisekhez kapcsolódó magyarázó változók mellett a társadalmi-demográfiai kontrollváltozókat is bevontuk az elemzésbe, hogy a magyarázó változók hatását az összetételbeli hatások kiszürésével vizsgálhassuk a hipotézisek verifikálása,

19 Az adatok megtalálhatók a KSH

https://www.ksh.hu/docs/hun/xstadat/xstadat_eves/i_wdsd002.html oldalán. 
illetve falszifikálása érdekében. Itt a kontrollált modelleket prezentáljuk a lentebbi 15. táblázatban, az 5.5-ös alfejezet teszteredményeivel együttesen.

$\mathrm{Az}$ összevont adatokon elkészített regressziós becslések eredményei alapján megállapíthatjuk, hogy a házasok kedvezőbb szubjektív életminőségről adtak számot, mint az egyedülállók (B 1,020 (0,402), p<0,05), illetve láttuk azt is, hogy az interakciós tag pozitív értéket mutatott $(\mathrm{B} 1,033(0,527), \mathrm{p}<0,05) .{ }^{20}$ Tehát elmondhatjuk, hogy a házasságban vagy törvényes élettársi kapcsolatban élők a válságot követően 2,053 (1,020+1,033) egységnyi indexpontértékkel értek el kedvezőbb szubjektív életminőséget az egyedülállókhoz képest (melyből tehát 1,033 az interakciós tag értéke, vagyis ennyivel módosította az Év változó a családi státusznak az életminőségre kifejtett befolyását). Viszont láttuk, hogy a modellben szereplő Év magyarázó változónk nem mutatott szignifikáns eredményt, illetve előjele negatív, ami szignifikáns kapcsolatnál azt jelentené, hogy a válság évei csökkentették a házasság kedvező hatásának 2006-hoz viszonyított előnyét, vagyis itt konvergenciáról lett volna szó (Moksony, 2006:86-87). Azonban, tekintettel arra, hogy a modellben az idő-dummy magyarázó változó nem mutatott szignifikáns eredményt, ezért a 2.a. hipotézisünket, mely szerint „a válság után nőtt a szubjektív életminőségben mutatkozó különbség a házasságban (élettársi kapcsolatban) élők és az egyedülállók között", az adatok nem igazolták. Vagyis a házasságban vagy törvényes élettársi kapcslatban élés szubjektív életminőségre kifejtett kedvező hatását az adataink alátámasztották, azonban a nem szignifikáns Év változó miatt a modell ugyanakkor nem jelezett egyértelmű divergenciát.

A munkaerő-piaci jelenlét esetében láttuk, hogy egyik magyarázó változónk (Év, dolgozik) sem mutatott szignifikáns eredményt, így alapvetően a 2.b. hipotézisünk, mely szerint „a munkaerő-piacon jelenlévők szubjektív életminősége a válság kedvezőtlen hatásának köszönhetően csökkent”, szintén nem nyert alátámasztást az adataink alapján. Továbbá, amikor a családi státusz és a

$20 \mathrm{Az}$ interakciós tag regressziós együttható értéke az interakciós hatás nagysága, ami azt jelenti, hogy a magyarázó változó „,egy egységnyi emelkedése - dummy változóról lévén szó az 1 egységnyi emelkedés itt azt jelenti, hogy a 0-val kódolt kategóriából áttérünk az 1-gyel kódoltra - mennyivel módosítja, növeli vagy csökkenti a másik magyarázó változó hatását”, vagyis a családi státusznak az életminőségre gyakorolt befolyása függ az Év változótól, és ezt a befolyást mutatja meg az interakciós tag együtthatója. (Moksony, 2006:84). 
munkaerő-piaci jelenlét együttes hatását vizsgáltuk a szubjektív életminőség alakulására, ebben az esetben sem kaptunk értékelhető eredményeket a válság hatásával kapcsolatban, tekintettel arra, hogy a családi státusz interakciós tagja, illetve a munkaerő-piaci jelenlét magyarázó változója nem volt szignifikáns az együttes modellben (17. táblázat 1 . modell).

\subsection{A szubjektív egészség, biztonságérzet és jövedelemi körülmények alapján kialakított társadalmi nagycsoportok polarizációs hipotéziseinek vizsgálata}

A szakirodalom alapján a szubjektív életminőség és a szubjektív egészség, biztonságérzet és jövedelmi körülmények között megismert pozitív kapcsolatot az önálló mintákon elkészített elemzéseink igazolták. Mind 2006-ban, mind 2012-ben minél kedvezőbb volt az egyének szubjektív egészségi állapota, minél inkább úgy látták, hogy nincsenek megélhetési problémáik és kijönnek a rendelkezésükre álló jövedelemükből, minél inkább biztonságban érzeték magukat a lakókörnyékükön, annál kedvezőbb szubjektív életminőséget értek el. $\mathrm{Az}$ eredményeket szintén a 15. táblázatban mutatjuk be, mely alapján megállapíthatjuk, hogy 2012-ben átlagosan 4,196 pontértékkel (B 4,196 (0,378), p<0,01) kedvezőbb pontot értek el a szubjektív életminőség skálán azok, akik kijöttek a bevételeikből, azokhoz képest, akik nem jöttek ki. Azonban sem a válság hatását mérő inteakciós tag, sem az idődummy változó nem mutatott szignifikáns összefüggést, így a szubjektív jövedelmi körülményekre felírt 3. a. sz. hipotézben megfogalmazott állításunkat, mely szerint „a válság éveiben nőtt a szubjektív életminőségbeli különbség azok között, akik kijönnek és akik nem jönnek ki a rendelkezésükre álló jövedelemből”, az adatok nem támasztották alá. A szubjektív általános egészségi állapotukat 'rossznak' és 'nagyon rossznak' értékelő lakosokkal szemben azok, akik jó (kielégítő, jó, nagyon jó) egészségi állapotnak örvendtek, átlagosan 4,701 pontértékkel (B 4,701 $(0,503), \mathrm{p}<0,01)$ kedvezőbb eredményt értek el a szubjektív életminőség skálán 2012-ben. Azonban az Év változója és a válság befolyását mérő szorzattényező itt sem mutatott szignifikáns kapcsolatot. Az eredmények tehát a 3. b. sz. hipotézisünket, mely szerint ,a válságot követően nőtt a szubjektív életminőségben mutatkozó 
különbség a jó és a rossz szubjektív egészségi állapottal rendelkező lakosok között”, nem igazolták. A biztonságérzet léte szintén pozitívan befolyásolta az életminőséget, azonban a csoportok közötti indexpontszám különbség a korábbi időszakban mért különbségekhez képest itt sem mutatott szignifikáns eltérést. Ezért a 3. c. sz. hipotézisünket, mely alapján feltételeztük, hogy „a recesszió éveiben nőtt a biztonságérzettel rendelkezők és a biztonsághiányt szenvedők szubjektív életminősége közötti különbség”, el kellett vetnünk.

15. táblázat: A társadalmi integráció, a szubjektív jövedelmi helyzet, a szubjektív egészség és a biztonságérzet hipotéziseinek a szubjektív életminőség mértékével kapcsolatban felépített regressziós modelljei, összevont keresztmetszeti adatok, OLS (sztenderdizálatlan regressziós együtthatók, szignifikancia szintek)

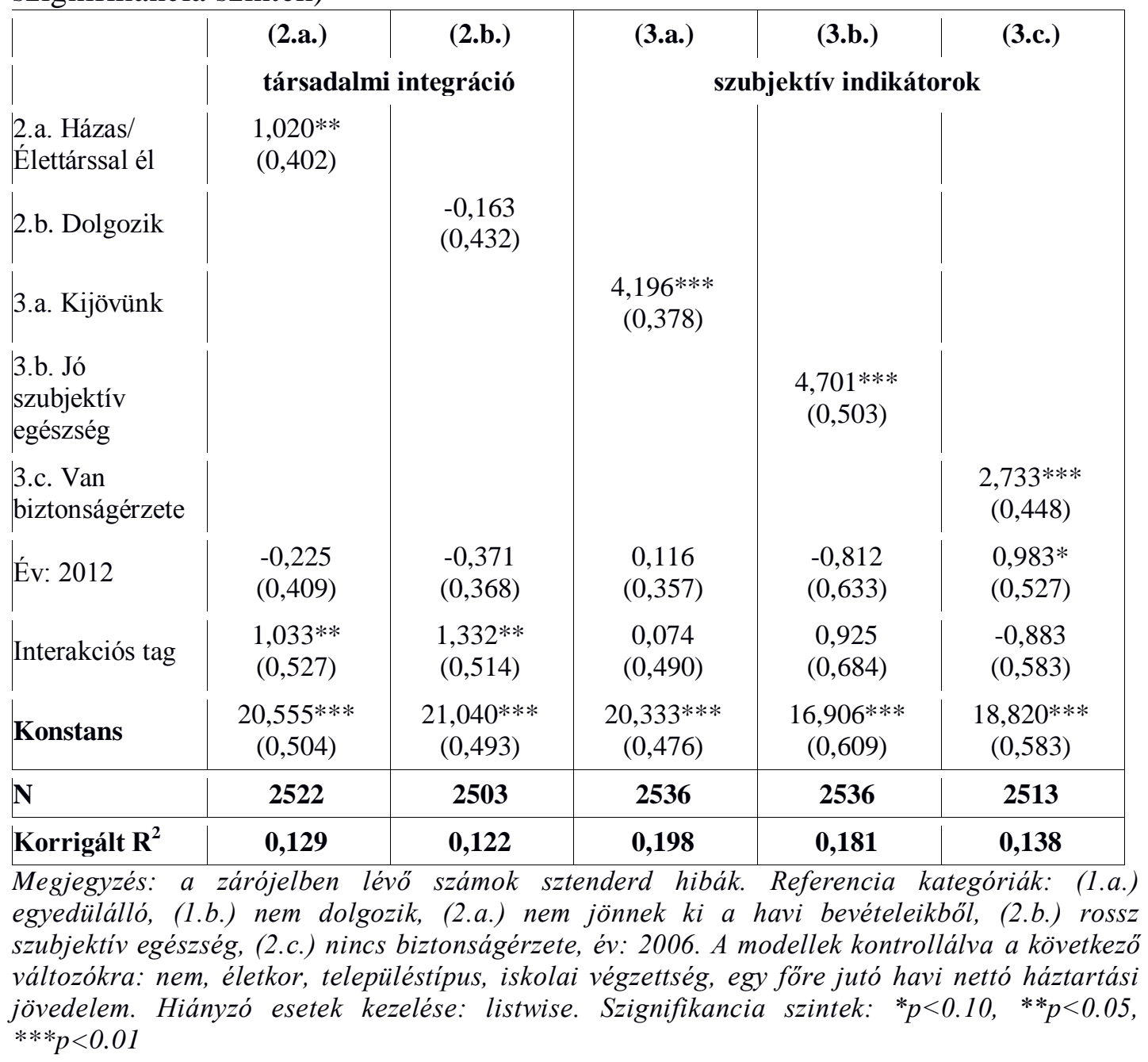

A szubjektív indikátorok alapján kialakított társadalmi nagycsoportok életminőségbeli különbségeiben a hipotéziscsoport indikátorainak együttes szerepeltetése esetén sem kaptunk más következtetésre okot adó eredményeket, 
tekintettel arra, hogy az interakciós tagokok nem mutattak szignifikáns kapcsolatot a függő változóval (17. táblázat 2. modell).

Összefoglalóan annyit tudunk elmondani, hogy a kutatásunkhoz kiválasztott, eddigiekben elemzett magyarázó változóknak, tehát a házasságban élsének, a munakerő-piaci jelenlétnek, a jó egészségnek, a jó szubjektív jövedelmi körülményeknek és a biztonságérzet léténeknek meghatározó szerepe van a multidimenzionális szubjektív életminőség alakulásában, azonban ezen dichotóm változók mentén kialakított társadalmi nagycsoportok szubjektív életminőségbeli különbségeinek a recesszió éveire anticipált megnövekedett eltéréseit az önálló (hipotézis-csoportonként felállított) regressziós modellekben mért eredményeink nem igazolták. Így a kutatásunk számára kialakított társadalmi nagycsoportoknak a válság éveiben bekövetkező polarizációját, mint magyarázó mechanizmust, nem tudtuk alátámasztani.

A kontrollváltozók hatásáról annyit tudunk elmondani, hogy a modellekben az életkor, az iskolai végzettség és a jövedelem fejtett ki szignifikáns hatást a szubjektív életminőség alakulására, ahogyan azt az előzetes elemzések az 5.1 és az 5.2 alfejezetben előre jelezték. A 30 év alattiakhoz képest, alapvetően mindegyik korcsoportnál kedvezőtlenebb szubjektív életminsőséget mértünk, jóllehet az aktív életkorban lévők: a 40-49 évesek és az 50-59 évesek csoportjai esetében láttuk a jelentősebb eltéréseket a referenciakategóriához képest. Jóval kedvezőbb szubjektív életminőséget érhettek el az érettségivel és a diplomával rendlekezők, azonban a szakmunkás végzettségűek csoportjánál - a referenciacsoporthoz képest - nem találtunk szignifikáns eltérést a szubjektív életminőség mértékében. A magasabb jövedelmet elérők szubjektív életminőséggel fennálló pozitív kapcsolatát ezek a modellek is kimutatták. A nem és a településtípus egyik esetben sem befolyásolták szignifikánsan a függő változónk alakulását (Függelék 13. és 14. táblázatok).

\subsection{Az anómia- és elidegenedésérzet hipotézisének vizsgálata}

Az anómia- és elidegenedésérzettel kapcsolatosan hipotézisünk szerint a válság éveiben Magyarországon az egyéni anómia- és elidegenedésérzet 
elterjedtsége megnőtt, a korábbi 2006-os évhez viszonyítva. E hipotézis vizsgálatakor első lépésben, a mindkét évben ugyanazon módon mért, ugyanazon technikával létrehozott egyéni anómia- és elidegenedésérzet skálán elért lakossági átlagokat vetettük össze. Az elemzés eredményei alapján (16. táblázat) látható, hogy 2012-ben magasabb a skálán elért átlagérték, mint 2006-ban (9,39 és 9,65). Azt, hogy a két átlagérték közötti különbség szignifikáns-e a kétmintás t-próbával ellenőriztük. Az értelemnélküliség, az elmagányosodás, az izoláció és a haszontalanságérzet változóival mért, átlagos egyéni anómia- és elidegenedésérzet Magyarországon valamelyest nagyobb elterjedtséget mutat 2012-ben, mint 2006-ban, a két év skálaátlagainak különbsége 1\%-os szinten szignifikáns. Így a 4. sz. hipotézisünk igazolást nyert.

16. táblázat: Anómia és elidegenedés skála átlagainak összehasonlítása (kétmintás tpróba), összevont keresztmetszeti adatokat

\begin{tabular}{|c|c|c|c|c|c|c|c|c|c|}
\hline & $\mathbf{N}^{*}$ & átlag & szórás & St. E. & F (sig.) & $\mathbf{t}$ & df & Sig. (2-tailed) & $\begin{array}{c}\text { Mean } \\
\text { differ. }\end{array}$ \\
\hline 2012 & 1965 & 9,659 & 2,819 & 0,0635 & $\begin{array}{c}0,557 \\
(0,456)\end{array}$ & 2,707 & 3421 &, $\mathbf{0 0 7}$ & 0,26097 \\
\hline 2006 & 1457 & 9,398 & 2,746 & 0,0719 & & \\
\hline
\end{tabular}

Az egyéni anómia- és elidegenedésérzetnek a szubjektív életminőségre gyakorolt befolyását vizsgálva, az önálló modellünk eredményei alapján azt látjuk, hogy az egyéni anómia- és elidegnedésérzet erős, negatív szignifikáns összefüggést mutatott a szubjektív életminőséggel, mellyel így a szakirodalomból megismert negatív kapcsolatot magunk is alátámasztottuk (17. sz. táblázat: 3. modell). Azonban a modellben az interakciós tag nem volt szignifikáns, így az általános, már bemutatott negatív kapcsolat fennállásától többet nem tudunk elmondani.

\subsection{Személyes jellemvonás hipotézisének vizsgálata}

A személyes beállítottság mérésére első lépésben, ahogyan arról már korábban beszámoltunk, négy személyiségjellemző alapján próbáltunk kialakítani egy pozitív (optimista, magabiztos) személyiséget mérő indexet főkomponens elemzéssel. Azonban a látens változót a KMO statisztika alacsony értéke miatt nem alkalmaztuk. Így az optimizmust, mint személyes beállítottságot az „Optimistán tekintek a jövőre” indikátor segítségével mértük 
(a statisztikákat lásd az F.7. sz. Függeléknél). A kétváltozós statisztikák igazolták, hogy az optimista szemlélet erős, pozitív kapcsolatban áll a szubjektív életminőséggel. Minél pozitívabb valakinek a látásmódja, annál valószínűbb, hogy kedvezőbb életminőséget ér el, jóllehet a kedvező életminőség is előidézhet pozitív szemléletmódot. Ugyanakkor tudjuk azt is a szakirodalomból, hogy a túlzott optimizmus az egyén által kezelhetetlen helyzetre adot helytelen válaszreakcióból is származhat, mint a rossz adaptációnak az eredménye (Cummins, 2014b).

A személyes beállítottságra felírt hipotézisünk vizsgálatát a 17. táblázat részeként mutatjuk be (4. modell). Az eredmények alapján elmondhatjuk, hogy ez a modellünk szignifikáns, így egyrészt megállapíthatjuk, hogy a személyes beállítottság és a szubjektív életminőség pozitív kapcsolatát adataink alátámasztották, ugyanakkor a változó hatását a szubjektív életminőség alakulására vonatkozóan a válság évei is befolyásolták. Tehát a pesszimista lakosokhoz képest az optimisták 2012-ben átlagosan 3,406 egységgel magasabb pontértéket (B 3,406 (0,356), p<0,01) értek el az életminőség skálán. Továbbá látjuk, hogy az idő-dummy változónk szintén pozitív előjellel szerepel, így a pozitív előjelü Év változó mellett az inetakciós tag pozitív értéke (B 1,623 $(0,477), \mathrm{p}<0,01)$ a csoportok divergenciáját jelzi (Moksony, 2006:87). Vagyis 1,623 egységnyi pontérték a regressziós egyenlet alapján az a becsült kategóriaátlagbeli különbség, mely a csoportok életminőségbeli különbségei között mutatkozott 2012-re (Buckley-Shang, 2003). Így az 5. sz. hipotézisünket, mely szerint „a válság után nőtt a szubjektív életminőségben mutatkozó különbség az optimisták és a pesszimisták között”, az eredményeink igazolták.

A kontrollváltozóknak a szubjektív életminőség alakulására kifejtett hatásukkal kapcsolatosan, mind az egyéni anómia- és elidegenedésérzet (3), mind az optimista beállítottság (4) modelljében, megállapíthatjuk, hogy a nem és a településtípus nem fejtett ki befolyást a függő változónkra, azonban az életkori korcsoportok, az iskolai végzettség és a jövedelem esetében itt is szignifikáns összefüggést mértünk. Ezek a kapcsolatok hasonló hatásokat mutattak, ahogyan arról fenetbb az (1) és (2) modelleknél beszámoltunk, melyeket itt nem ismételünk meg (F. 14. sz. táblázat). 
17. táblázat: A hipotéziscsoportoknak a szubjektív életminőség mértékével kapcsolatos regressziós modelljei, összevont keresztmetszeti adatok, OLS (sztenderdizálatlan regressziós együtthatók, szignifikancia szintek)

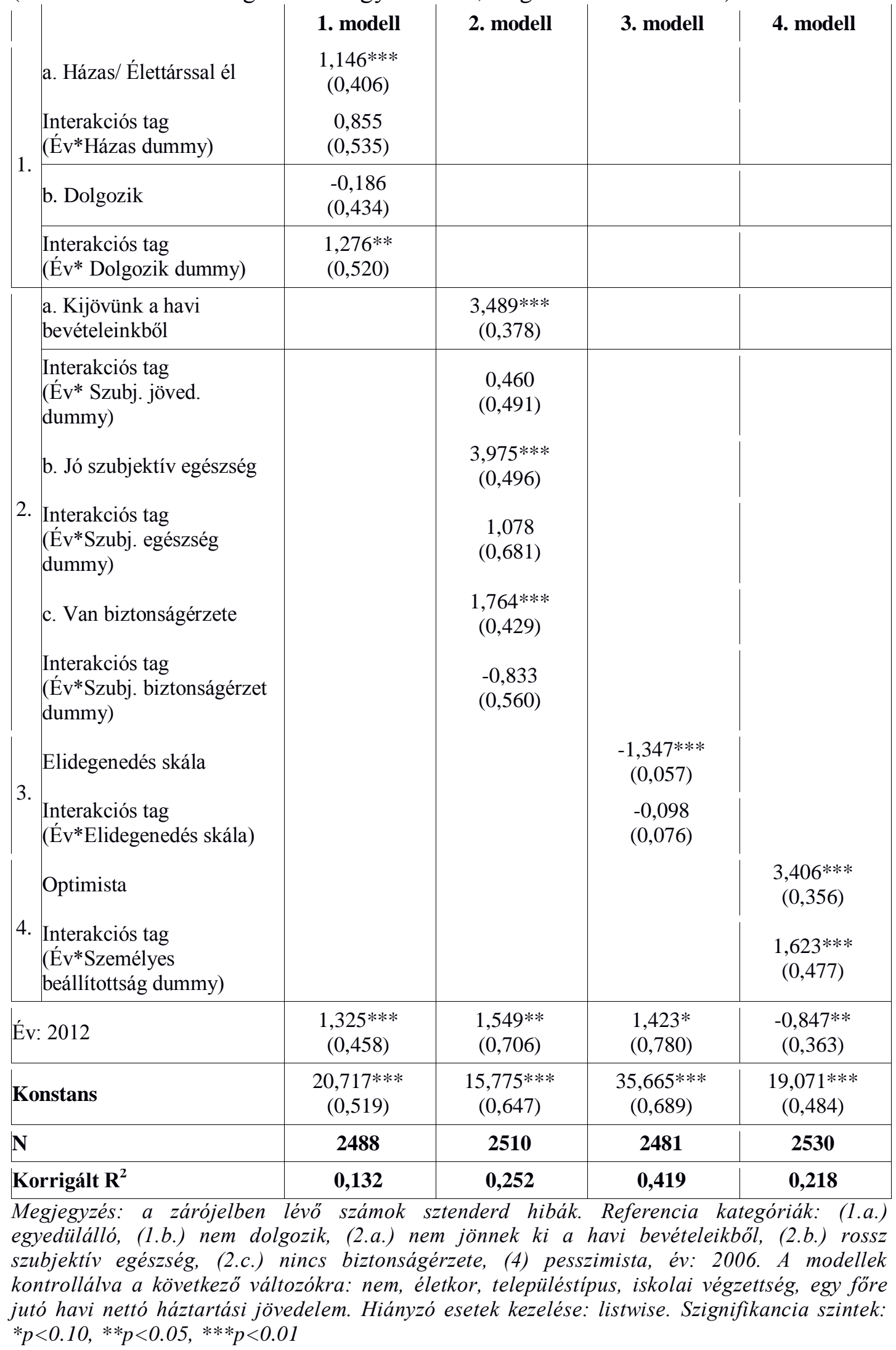


Arra a kérdésre, hogy 2012-ben mi adott okot a bizakodásra, és vált az optimista beállítottság a szubjektív életminőséget jelentősen befolyásoló tényezővé, több hipotetikus magyarázat is felmerülhet, ahogyan fentebb már jeleztük. Továbbá szem előtt tartjuk a hatáselemzéseknek azon kritáriumát, mely szerint a sztenderd 'különbség a különbségekben' (DID) módszer elsősorban akkor alkalmazható, ha és amennyiben a vizsgált időszakban más jelentősebb strukturális változást előidéző külső (pozitív vagy negatív hatású) esemény nem következett be a vizsgált populáció életében. Azonban az említett 2010-es országgyülési választás ilyen eseménynek tudható be, ezért annak hatását a difference-in-difference-in-differences (DDD) módszerével, amennyiben az adatok lehetővé tennék, szükséges lenne levonni (National Bureau of Economic Research, 2007). Erre a pontra az összefoglaló fejezetben visszatérünk.

\subsection{Az integrált modellek}

$\mathrm{Az}$ empirikus elemzés eddigi részében egyes hipotézisekhez kapcsolódóan vizsgáltuk meg a magyarázó változók, változócsoportok szerepét a szubjektív életminőség alakulásában, az összetételi hatások kiszürése mellett. Azonban a lakosság szubjektív életminőségét a hipotézisekben szereplő változók együttesen határozzák meg, a változócsoportok között is fennállnak kapcsolatok, ezért ahhoz, hogy az egyes magyarázó változók önálló szerepét vizsgálni lehessen, mindegyik változót figyelembe kell venni. Ennek érdekében a vizsgálatunk utolsó szakaszában integrált modelleket építettünk fel, hasonlóan az eddigi eljáráshoz, melyek alapján az elemzésünk eredményeit a 18. táblázatban mutatjuk be. (A kontrollváltozókat is tartalmazó II. modellt lásd a Függelék 15. sz. táblázatában.)

A lakosság multidimenionális szubjektív életminőségét befolyásoló magyarázó változók önálló szerepét a strukturális hatások érvényesülése mellett az I. modellben prezentáltuk, míg a II. modellben az összetételbeli hatások kiszürésével közöltük. A regressziós elemzések eredményei alapján egyrészt látható, hogy az Év változónk egyik modellben sem szignifikáns. Tehát az integrált modell alapján nem tudunk olyan újabb eredményt bemutatni, ami a fentebb levezetett hipotézis-tesztekkel kapcsolatosan, az ott tett 
megállapításainkat alapvetően módosítaná. Másrészt, a II. modell alapján látjuk azt is, hogy a lakosság szubjektív életminőségének alakulását alapvetően mindegyik magyarázó változónk szignifikáns befolyásolja. Míg a házasság, kifejtve kedvező egzisztenciális és pszichés hatásait (Diener et al., 1999; FreyStutzer, 2003a), kedvezőbb szubjektív életminőséggel járt együtt a válságot követően is, addig a munkaerö-piaci jelenlét 2012-ben valamivel alacsonyabb jóllétet vont maga után. Itt megjegyezzük, hogy a munkaerő-piaci jelenlét változónk a korábbiakban (15. táblázat 2.b. és a 17. táblázat 1.b. modelljei) nem volt szignifikáns hatással az életminőség alakulására, itt az integrált modellben vált szignifikánssá. A szubjektív életminőségnek a három szubjektív magyarázó változóval (szubjektív jövedelmi helyzet, szubjektív egészségi állapot, és bitonságérzet) korábban mért pozitív kapcsolata az integrált modellben is megmaradt. Jóllehet sem a korábbi modelleknél, sem az integrált modellben nem találtunk szignifikáns eltérést a szubjektív változók mentén kialakított dichotóm csoportok életminőségbeli különbségeiben a válságot követően. Hasonlóképpen megmaradt az inetgrált modellben az egyéni anómia- és elidegendésérzet negatív, míg a jövőbe bizakodóan tekintő optimista attitűd pozitív összefüggése a szubjektív életminőséggel. Ugyanakkor láttuk azt is, hogy a II. modellben kettő változó interakciós tagja mutatott szignifikáns pozitív eredményt, az optimista beállítottság és a munkaerő-piaci jelenlét szorzattényezője, azonban az idődummy (Év) változónk nem volt szignifikáns a modellben, így nem mondhatjuk el, hogy a csoportok divergenciáját mérték adataink.

A kontrollváltozók szerepéről a II. számú integrált modellben annyit mondhatunk el, hogy az életkor, a felsőfokú iskolai végzettség és a jövedelem hatása szignifikáns. A fiatalokhoz képest mindegyik életkori korcsoport kedvezőtlenebb jóllétről adott számot, a többi változó együttes hatásával itt az 50-59 évesek csoportja érte el a legkedvezőtlenebb életminőséget, míg az iskolai végzettség alapján a diplomások vagy magasabb iskolai végzettség rendelkezők a legkedvezőbbet. A magasabb egy főre eső háztartási jövedelem kedvezőbb jólléttel járt együtt, azonban a nem és a településtúpus nem befolyásolta szignifikánsan a szubjektív életminőség alakulását (F.15. sz. táblázat). 
18. táblázat: A szubjektív életminőség integrált regressziós modelljei, összevont keresztmetszeti adatok, OLS (sztenderdizálatlan regressziós együtthatók, szignifikancia szintek)

\begin{tabular}{|c|c|c|}
\hline & I. modell & II. modell \\
\hline Év: 2012 & $0,474(1,033)$ & $0,615(1,173)$ \\
\hline Házas/Élettárssal él & $0,270(0,270)$ & $0,640 * *(0,314)$ \\
\hline Inter (Év*Házas dummy) & $-0,250(0,354)$ & $0,007(0,412)$ \\
\hline Dolgozik & $-0,476 *(0,270)$ & $-0,633 *(0,338)$ \\
\hline Inter (Év*Dolgozik dummy) & $0,353(0,360)$ & $0,711 *(0,414)$ \\
\hline Kijönnek a havi bevételeikből & $2,794 * * *(0,279)$ & $2,367 * * *(0,319)$ \\
\hline Inter (Év*Szubj. jöv. helyzet dummy) & $0,029(0,369)$ & $-0,080(0,420)$ \\
\hline Jó szubjektív egészség & $2,635 * * *(0,392)$ & $2,316 * * *(0,429)$ \\
\hline Inter (Év*Szubj. egészség dummy) & $0,035(0,534)$ & $-0,089(0,597)$ \\
\hline Van biztonságérzete & $0,877 * * *(0,320)$ & $1,045 * * *(0,360)$ \\
\hline Inter (Év*Biztonságérzet dummy) & $-0,559(0,410)$ & $-0,646(0,469)$ \\
\hline Elidegenedés skála & $-1,160 * * *(0,053)$ & $-1,109 * * *(0,058)$ \\
\hline Inter (Év*Elidegenedés skála) & $-0,046(0,069)$ & $-0,057(0,079)$ \\
\hline Optimista & $1,939 * * *(0,270)$ & $1,625 * * *(0,301)$ \\
\hline $\begin{array}{l}\text { Inter (Év*Személyes beállítottság } \\
\text { dummy) }\end{array}$ & $0,781 * *(0,364)$ & $0,977 * *(0,414)$ \\
\hline Kontrollváltozók & nem & igen \\
\hline Konstans & $27,002 * * *(0,783)$ & $27,541 * * *(0,920)$ \\
\hline $\mathbf{N}$ & 3133 & 2404 \\
\hline Korrigált $\mathbf{R}_{2}$ & 0,510 & 0,496 \\
\hline
\end{tabular}

Megjegyzés: zárójelben a sztenderd hibák. Referencia kategóriák: év: 2006, (1.a.) egyedülálló, (1.b.) nem dolgozik, (2.a.) nem jönnek ki a havi bevételeikböl, (2.b.) rossz szubjektív egészség, (2.c.) nincs biztonságérzete, (4) pesszimista. Kontrollálva: nem, életkor, településtípus, iskolai végzettség, és az egy före jutó havi nettó háztartási jövedelem változókra. Hiányzó esetek: listwise. Szignifikancia szintek: $* p<0.10, * * p<0.05, * * * p<0.01$.

Az integrált modellek magyarázott variancia értéke igen magas (korrigált $\mathrm{R}^{2}$ értékei: $51 \%$, és 49,6\%), mely magas értékek a kutatási előzményeknél említettek szerint a szubjektív modellek sajátossága (Michalos-Zumbo, 2002). Ebben az értelemben a modellek összehasonlítása, illetve a hipotézisek magyarázó erejének összevetése nem volt célja a kutatásunknak. 


\section{6. Összefoglalás}

\subsection{A kutatási kérdések és hipotézisek megválaszolása}

Kutatásunkban a válság éveinek a hatását vizsgáltuk a szubjektív életminőségre és annak meghatározó tényezőire vonatkozóan. Ez a hatásvizsgálat jelentette egyrészt a lakosság átlagos jóllétének a vizsgálatát a recesszió időszakában, másrészt a kutatás számára kiválasztott dichotóm társadalmi nagycsoportok életminőségében bekövetkező változásoknak az elemzését. A válság társadalmigazdasági folyamatokra gyakorolt kedvezőtlen hatását jelző makro és mikro statisztikák és a szakirodalom alapján a válság-hipotézisünkben azt az állítást fogalmaztuk meg, hogy a recesszió éveiben csökkent a lakosság átlagos szubjektív életminősége. Jóllehet azt a tényt, hogy a válság hatását lehetséges, hogy nem fogjuk tudni mérni, a bevezetőben is jeleztük, tekintettel arra, hogy több empirikus kutatás nem mért jelentősebb eltérést a szubjektív jóllét mértékében a válságot követő években (Gudmundsdottir, 2013; Cummins-Wooden, 2014).

Továbbá a szakirodalom alapján láttuk, hogy a recesszió a sérülékeny társadalmi csoportokat kedvezőtlenebbül érintette, ezért megpróbáltuk a gazdasági válság hatását egyes társadalmi nagycsoportok esetében is mérni. Figyelembe véve azt a tényt, hogy a válság hatását számos irodalom magyar adatok bevonásával is tárgyalta, az azokban feltárt összefüggések ismételt vizsgálatát igyekeztünk elkerülni. Ezért kettő objektív és négy szubjektív indikátor alapján hoztunk létre dichotóm csoportokat, amelyek esetében a csoportok szubjektív életminőségbeli különbségeiben megmutatkozó különbségeket (növekedést vagy csökkenést) mértük, a válság elötti időszakkal való összevetésben. A családi státusz és a munkaerő-piaci jelenlét objektív indikátorai mellett, olyan szubjektív indikátorok mentén kialakított nagycsoportokat vizsgáltunk, amelyek az egyéni egészséghez, a szubjektív anyagi körülményekhez, a biztonságérzethez és az optimista szemléletmódhoz kapcsolódtak. Ezért kutatásunk e területen feltáró kutatás is volt a maga nemében, mely így jelentősebb előzetes összefüggésvizsgálatokat igényelt. 
A válság hatására felírt hipotézisünk tesztelése alapján megállapíthattuk, hogy az összetételbeli hatások kiszürését követően, a lakosság szubjektív életminősége nem mutatott szignifikáns csökkenést 2012-re a korábbi, 2006-os időszakhoz viszonyítva.

Az eredmények magyarázatára azt a „set-point” elméletet (Headey, 2006, 2010; Headey et al., 2014) idézzük, amely alapján feltételezhető, hogy a kedvezőtlen irányú (nagyobb szélsőségektől mentesnek tekinthető) társadalmigazdasági változásoknak az egyéni szintủ lecsapódásai időszakos változásokat eredményezhettek ugyan a lakosság szubjektív életminőségének alakulásában, azonban az idő előrehaladtával, a lakosság alkalmazkodásának köszönhetően, a statisztikák alapján negatív csúcspontnak tekinthető 2012-es év már nem mutatott szignifikáns befolyást a lakosság szubjektív életminőségére a korábbi, válság előtti időszakhoz viszonyítva.

A dichotóm társadalmi nagycsoportok vizsgálatai alapján elmondhatjuk, hogy a házasság szubjektív életminőségre kifejtett kedvező hatását mind az önálló, mind az integrált modelljeink alátámasztották. Tehát az egyedülállókhoz képest azok, akik házasságban vagy törvényes élettársi kapcsolatban éltek, kedvezőbb szubjektív életminőséget értek el 2012-ben is. Ugyan a válság hatására itt felírt hipotézisünk nem igazolódott, azonban az alapvető összefüggést, mely szerint a házasság, kedvező egzisztenciális és pszichés hatásainak köszönhetően (Frey-Stutzer, 2003a, 2003b) pozitívan hat az egyéni jóllét alakulására (Diener et al., 1999; Oswald-Wu, 2009; Graham et al., 2010), a mi eredményeink is igazolták. Az alskálák elemzésénél láttuk, hogy a házasság a boldogság alskálával állt erős pozitív kapcsolatban, mely hatás kiemelkedő erőssége 2012-re valamelyest enyhült, feltételezhetően ennek okán nem konfirmálták adataink a válság befolyására itt felírt hipotézisünket.

A munkaerőpiaci jelenléttel kapcsolatosan kutatásunk során nem a hagyományos aktív-inaktív dichotóm kategóriákat választottuk, ahol az aktívak között a munkanélküliek is szerepelnek, hanem az előző hét jellemző tevékenységét vettük alapul, és a 'dolgozik-nem dolgozik' dichotóm csoportok életminőségbeli eltéréseit vizsgáltuk meg a válságot követően. Amíg a kétváltozós összefüggések, jóllehet gyenge erősségü kapcsolatok mellett azt 
mutatták, hogy azok, akik dolgoznak, nagyobb arányban fordulnak elő az elégedettek, az önmegvalósítók, a boldogok és a pozitív érzelmi egyenleggel rendelkezők között, mint a teljes mintában, addig a többváltozós elemzések esetében, köszönhetően a gyenge kapcsolatoknak, az önálló modelleknél nem találtunk szignifikáns összefüggést a szubjektív életminőség mértékével kapcsolatosan. Az integrált regressziós modellek eredményei alapján - ahol az elemzésbe bevont összes változó együttes hatása érvényesült -, pedig azt állapíthattuk meg, jóllehet itt is gyenge szignifikancia mellett, hogy a dolgozók csoportjának szubjektív életminősége 2012-re valamelyest csökkent.

Az anyagi problémák nélküli jövedelmi körülményeknek, a jó szubjektív egészségnek és a biztonságérzet jelenlétének az egyének szubjektív életminőségére kifejtett pozitív hatását mind az önálló, mind az integrált modelljeink igazolták. Azonban a válság hatásaként a szubjektív dichotóm csoportok polarizációjára megfogalmazott hipotéziseinket a teszteredmények nem támasztották alá, jóllehet a gazdasági válság a sérülékeny társadalmi csoportokat érintette kedvezőtlenebbül (European Commission, 2014; SzivósTóth, 2015). Akik nehezen jöttek ki a rendelkezésükre álló jövedelmükből, illetve akik rossznak értékelték általános egészségi állapotukat, és akik lakókörnyékükön biztonsághiányt szenvedtek el, a jó anyagi helyzetü, jó egészségben lévő, és biztonságérzettel rendelkező csoporttársaikhoz képest viszonyított életminőségbeli különbségeik nem tértek el szignifikánsan 2012-ben a 2006-os különbségekhez képest, vagyis nem váltak sokkal rosszabbá a válság éveinek köszönhetően.

Az egyéni anómia- és elidegenedésérzet elterjedtségére vonatkozóan a válság hatásaként elsősorban az attitűd elterjedtségének a változására voltunk kiváncsiak. A korábbi szakirodalom alapján láttuk, hogy Magyarországon az átmenet éveit jellemző recesszió idején nőtt az anómiás tünetek és az elidegenedésérzet elterjedtsége a lakosság körében, jóllehet az attitüd gyakorisága a '90-es évek második felére csökkent (Spéder et al., 1998; ElekesPaksi, 2000; Hegedűs, 2000). Az adataink a válsággal kapcsolatos feltételezésünket alátámasztották, Magyarországon nőtt az egyéni anómia- és elidegenedésérzet elterjedtsége 2012-re, a korábbi időszakhoz viszonyítva. A 
szakirodalomból ismert, a szubjektív jóllét és az egyéni anómia- és elidegenedésérzet közötti negatív kapcsolatot (Spéder-Kapitány, 2002) eredményeink az önálló és az integrált regressziós modelleken szintén alátámasztották.

A személyes jellemvonás szubjektív életminőséget meghatározó szerepére már a korai panelvizsgálatok rámutattak (Headey-Wearing, 1989; Diener-Lucas, 1999). A személyes beállítottság, az optimista látásmód abban az esetben is pozitív összefüggést mutatott az egyéni jóllét mértékével, amikor az egyén olyan élethelyzeben állt helyt, melyhez erőforrásai nem voltak elégségesek, ezért kénytelen volt lemondani életcéljairól, azokat át kellett értékelnie, esetleg új célokat kitűzni maga elé (Wrosch-Scheier, 2003). A gazdasági válság során megváltozott életkörülmények számtalan esetben állíthatták az embereket mindennapjaik során ilyen és ehhez hasonló helyzetek elé. Ezért úgy gondoltuk, hogy az optimista beállítottság, a nehézségeken történő felülkerekedésben, adaptációs technikaként lényeges szerepet játszhatott a válság kedvezőtlen következményeinek leküzdésében, így az egyének életminőségének alakulásában. Ugyanakkor láttuk azt is, hogy a túlzott optimizmus egy rossz alkalmazkodásnak a jele is lehet (Cummins et al., 2014). Vizsgálatunkban a jövőbe bizakodóan tekintő attitűddel mértük a személyes beállítottságot, és az optimisták és pesszimisták dichotóm csoportjait hoztuk létre. Mind az önálló, mind az integrált regressziós modellek a két csoport szubjektív életminőségbeli divergenciáját méréték a válságot követően. Tehát az optimista szemlélet szubjektív életminőség alakulására kifejtett befolyását a válság évei felerősítettek, 2006-hoz képest 2012-ben jóval kedvezőbb életminőséget érhettek el az optimista beállítottságú egyének. Feltételezzük azonban azt is, hogy a magyarok pesszimista szemlélete a 2000-es éveket követően veszített jelentőségéből, szemben a '90-es éveket jellemző recesszió időszakával, amikor empirikus vizsgálatok a magyarokat jellemző borúlátó attitüdnek, mint megörökölt társadalmi normának a fennmaradt hatásával hozták összefüggésbe a szubjektív jóllét akkori kedvezőtlen értékeit (Lengyel-Hegedüs, 2004).

Ugyanakkor itt szükséges megjegyezni, hogy a bevezetőben tárgyaltak szerint, a szubjektív jóllét indikátorok (élettel való elégedettség, boldogság) alapján a 2010-es évben mért javulás, ahogyan már említettük, feltehetően az országgyülési 
választásoknak volt köszönhető. Tehát figyelembe kellett volna venni a regressziós egyenletek felírásakor, és a difference-in-difference-in-differences (DDD) módszere alapján le kellett volna ennek az évnek a hatását vonni. Tudjuk, hogy a sztenderd 'különbség a különbségekben' módszer akkor alkalmazható külső társadalmi hatások vizsgálatára, ha és amennyiben más lényeges, strukturális változásokat előidézhető hatás nem történik a vizsgált időszakban. Azonban a 2010es ESS adatfelvétel nem tartalmazta az ehhez szükséges azonos kérdéssorokat, így megfelelő adatok hiányában ezt a hatást nem tudtuk levonni a 2008 és 2012 között mért ún. „válság-hatás”-ból (National Bureau of Economic Research, 2007).

\subsection{A kutatás tudományos eredményei}

A kutatásunk tudományos eredményeit a következőkben foglaljuk össze: a kuatás során az allardti koncepción alapuló multidimenzionális szubjektív életminőség indikátor kifejlesztése a munkánk egyik hozzáadott értéke. Ez a kutatás elsődleges tudományos eredménye, tekintettel arra, hogy a magyar szociológiában a szubjektív jóllétet és a szubjektív életminőséget leggyakrabban az élettel való elégedettség vagy a boldogság egyitemü indikátoraival mérték az empirikus kutatások során (Spéder et al., 1998; Spéder-Kapitány, 2002; Lengyel-Janky, 2003; Utasi, 2008; 2011), illetve ezeknek a mutatóknak összevont mérőeszközeivel, ezért a kidolgozott multidimenzionális szubjektív életminőség indikátorunk hiánypótló. Jelentőségét szeretnénk azzal is hangsúlyozni, hogy munkánkkal ahhoz a társadalmi jelzőszámrendszer mozgalomhoz kívánunk csatlakozni, melynek keretében a hazai statisztikai rendszerben bevezetésre kerültek az egyéni jóllét és életminőség szubjektív indikátorai (Andorka, 1996; Harcsa-Spéder, 1999).

Fő eredménye kutatásunknak, hogy megállapíthattuk, Magyarországon a válság évei után a lakosság szubjektív életminőségében, az összetételi hatások kiszürése mellett, nem csökkent szignifikánsan az átlagos szubjektív életminőség. Ezzel egy korábbi teórának, a 'set-point' elméletnek a relevanciáját magyar adtokon a gazdasági válság hatásával kapcsolatban mi magunk is konfirmáltuk, hasonlóan más kutatásokhoz, melyek esetében szintén a szubjektív jóllét csökkenését anticipálták a kutatók, azonban azt nem tudták empirikusan igazolni (Clench-Aas\&Holte, 2017; Cummins- 
Wooden, 2014; Gudmundsdottir, 2013; Gudmundsdottir et al., 2016).

Kutatásunk alapján megállapíthattuk továbbá, hogy Magyarországon a válság éveiben szignifikánsan nőtt az anómia- és elidegenedésérzet elterjedtsége a lakosság körében.

Adataink igazolták, hogy Magyarországon az egydülállókhoz képest a házasok (törvényes párkapcsolatban élők) kedvezőbb szubjektív életminőséget értek el a recesszió időszakában is. Adataink alátámasztották továbbá, hogy a válság éveinek hatásaként a munkaerö-piacon jelenlévők körében valamelyest kedvezőtlenebb szubjektív életminőséget mértünk, mint azok között, akik nem dolgoztak.

Eredményeink igazolták azt is, hogy az egyén percepciója saját jövedelmi körülményeiröl, illetve egészségi állapotáról és a lakókörnyezetében megélt biztonságáról, pozitív összefüggésben áll a szubjektív életminőséggel. Akik kedvezőbben értékelték anyagi körülményeiket, illetve általános egészségi állapotukat és biztonságérzetről adtak számot, a válságot követően is kedvezőbb szubjektív életminőséget értek el. Azonban a dichotóm csoportok polarizációját, mint a válság hatását adatainkkal nem tudtuk igazolni. Tehát nem találtunk szignifikáns szubjektív életminőségbeli eltérést azok között, akik kijönnek és akik nem jönnek ki a rendelkezésükre álló jövedelemböl, a 2006-os és 2012-es évek összevetésében. Ahogyan a gazdasági válságot követően nem változott a szubjektív életminőségben mutatkozó különbség azok között sem, akik jó, illetve akik rossz állapotban érezték az általános egészségi állapotukat. Továbbá a biztonságérzettel rendelkezők és a biztonságérzet hiányáról számot adó lakosok szubjektív életminőségbeli különbsége sem tért el szignifikáns mértékben 2012-ben a válság előtti időszakhoz viszonyítva.

Kutatásunk során konfirmáltuk a személyes beállítottság és a szubjektív életminőség pozitív kapcsolatát, ugyanakkor a válság hatására felírt hipotézisünket eredményeink verifikálták, tehát az optimista és a pesszimista beállítottságú egyének szubjektív életminőségbeli különbsége 2012-re jelentősen megnőtt, vagyis a válság évei felerősítették az optimista attitűd szubjektív életminőségre gyakorolt befolyását. A pesszimistákkal szemben az optimisták jóval kedvezőbb szubjektív életminőséget értek el a válságot követően. 
Azonban a kutatásunk tudományos megállapításainak számbavételekor három fő tényező hatására szertnénk felhívni a figyelmet. Egyrészt a már említett országgyülési választások évének, a 2010-es évnek a hatására, mely természetesen más hatások mellett, de jelentősen befolyásolhatta eredményeinket. Másrészt, a válság előtti makrofolyamatok hatására, mellyel kapcsolatosan azt láttuk, hogy Magyarországon a gazdaság stagnálása már 2006-tól megkezdődött, tehát ekkor már a GDP volumen-indexe nem mutatott növekedést és a lakossági fogyasztás mértéke is visszaesett (1. sz. táblázat). Ezeket a hatásokat azonban nem tudtuk szétbontani, illetve ezeknek a hatásoknak a lakosság szubjektív életminőségének alakulásában betöltött szerepére a dolgozat nem tudott választ adni. Ugyanakkor, az általános hatásvizsgálat okán, egy széleskörü szakirodalmi áttekintéssel próbáltunk a szubjektív jóllét területén tisztán látni, és minden lehetőséget számba venni, de ezzel együtt nem gondoljuk, hogy a kutatási kérdésünkre a megoldást megtaláltuk. Mindamellett volt egy elképzelésünk arról, hogy a gazdasági válság miként befolyásolta a társadalmi mechanizmusokat, a lakosság társadalmi nagycsoportjainak életminőségét, mely elképzelés vizsgálatát dolgozatunkon szisztematikusan végigvittünk. Itt ismét emlékeztetünk a kutatási probléma feltárásának, mérésének nehézkes voltára. Ahogyan arról már korábban beszámoltunk, láthattuk, hogy a válság kirobbanását követően Izlandon a válság évében a bankrendszer összeomlott, tehát egy sokkal erősebb sokkhatás érte a társadalmat (Gylfason et al., 2010), mint a hasonló fejlettségü nyugat-európai országokat, ezért az izlandi kutatók egyértelműen a szubjektív jóllét csökkenését vártak a válság után. Azonban mégsem következett be, sőt 2009-ben már javuló boldogságértékeket mutattak a mérések (Gudmundsdottir, 2013). Ebben az értelemben a közvetlen családi kapcsolatok szerepére, annak szubjektív életminőséget javító hatására a hazai kutatások is ráirányították a figyelmet (Utasi, 2008). 


\subsection{A kutatás korlátai és javasolt további kutatási irányok}

A kutatás gyengeségeit az alábbiakban foglaljuk össze:

a.) a többdimenziós indikátorunk kialakításakor a „Loving” dimenzió kérdését a két évben részben eltérően kérdezték le és eltérő skálán mérték, jóllehet a kérdések tartalmilag a megragadni kívánt szükségletdimenziót megfelelően leképezték, illetve a szummatív életminőség skála kialakításához azonos terjedelmüre kódoltuk a változót,

b.) az adatállomány a jövedelem adatait háztartásra vonatkozóan tartalmazta, és nem egyéni szinten, így a jövedelemváltozó transzformációja bizonyos mértékben torzította az eredményeket,

c.) a hiányzó adatokat az összevont keresztmetszeti adatok elemzésekor listwise módszerrel kezeltük, így az egyes változók hiányzó adatai összeadódtak, azonban jelentős adathiányt a hiányzó jövedelemadatok okoztak elsősorban, de a jövedelmüket nem megadók körében nem találtunk eltérö összefüggéseket az ellenörző elemzések során, mindemellett a hiányzó adatok okán az eredmények általánosításával óvatosan bántunk,

d.) hiányossága még a kutatásunknak, hogy az általunk kifejlesztett multidimenzionális szubjektív életminőség indikátort nem tudtuk hasonló magyar mérőeszközzel összevetni,

e.) továbbá hiányossága vizsgálatunknak, hogy a 2010-es év hatását nem tudtuk a regressziós becslések során figyelembe venni, tekintettel arra, hogy adott év ESS adatfelvétele nem tartalmazott minden szükséges kérdést a megfelelő módszer (DDD) alkalmazásához.

A javasolt kutatási irányt megelőzően jelen kutatási terület javasolt fejlesztési irányát szeretnénk megjelölölni, annak érdekében, hogy további kutatási irányokat is ki lehessen jelölni. Így elsősorban a szubjektív életminőség alakulásában játszott tényezők hosszú távú hatásainak vizsgálatához a kutatási területhez kapcsolódó szubjektív indikátorok hazai háztartáspanel adatfelvételbe történő integrálását tartjuk 
szükségesnek, amely lehetővé tenné az érzékenyebb elemzési technikák alkalmazását. Továbbá szükségesnek tartanánk többdimenziós indikátorok bevezetését a hazai statisztikai rendszerbe a lakosság szubjektív életminőségének monitorozása céljából. Az újabb indikátorok hozzájárulhatnak a nemzeti számlák rendszerének átalakításához is (Diener et al., 2015).

A jövőre irányuló kutatási irányként jelöljük meg továbbá az egyes speciális társadalmi csoportok szubjektív életminőségét mérő, az eltérő diszciplínák meghatározó elméletei alapján kimunkált általános és speciális multidimenzionális indikátorok kifejlesztését. Ezt követően ezen indikátorok folyamatos vizsgálatát tartjuk indokoltnak, annak érdekében, hogy mélyrehatóbb képet kapjunk a magyar társadalom szegmenseiről, amelyet a jelenlegi egy-két általános szubjektív indikátorra épülö, akár hosszútávú vagy keresztmetszeti felvételeken alapuló elemzések nem pótolhatnak. Továbbá a hazai demográfiai folyamatok monitorozásához kapcsolódóan is javasoljuk a többdimenziós indikátorok kialakítását az életminőség mérésével kapcsolatosan (Rossouw-Pacheco, 2012). A javasolt fejlesztésekkel az indikátorrendszerek tovább bővülhetnek, mellyel a kutatási eredmények is hatékonyabban épülhetnek be a hazai szakpolitikákba, hozzájárulva a társadalom kedvezőbb jóllétéhez és életminőséghez. 


\section{Függelék}

\section{F.1. Az életminőség két átfogó modellje}

F.1. táblázat: Az allardti „Having-Loving-Being” modell (Allardt, 1973), és a cumminsi átfogó életminőség modell (Cummins, 1993, idézi Veenhoven, 2000)

Having-Loving-Being

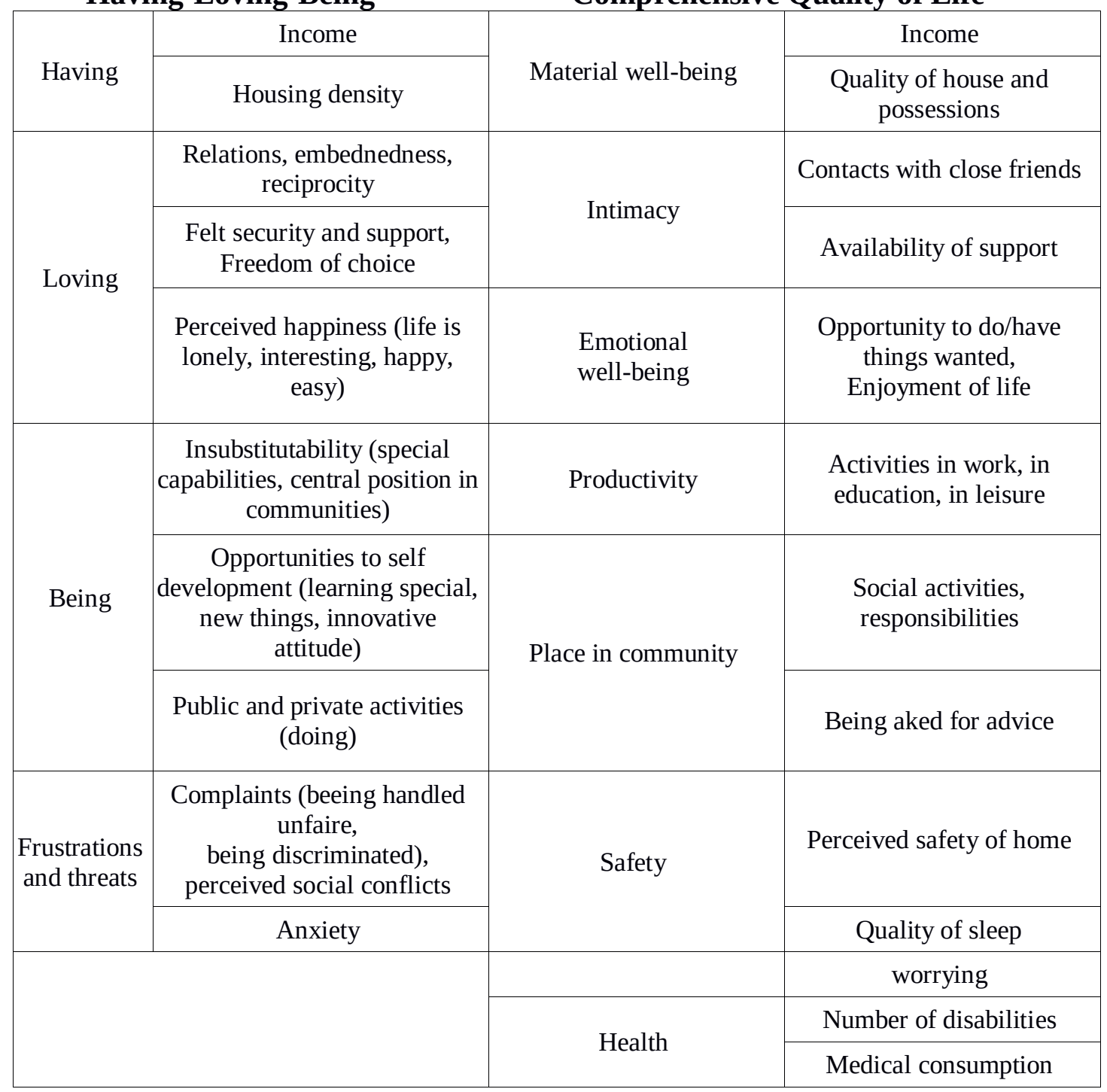




\section{F.2. A többdimenziós élettel való elégedettségi index}

F.2. táblázat: Az élettel való elégedettséget mérő index (Life Satisfaction (LS) Index*)

\begin{tabular}{|l|l|l|}
\hline 1. & $\begin{array}{l}\text { How do you feel about your life as a whole? } \\
\text { Összességében hogyan látja/értékeli az életét? }\end{array}$ & 1-től 9-ig terjedő skálán \\
\hline 2. & $\begin{array}{l}\text { How do you feel about the sense of purpose and meaning in your life? } \\
\text { Hogyan értékeli az életcéljait, az élete értelmét? }\end{array}$ & 1-től 9-ig terjedő skálán \\
\hline 3. & $\begin{array}{l}\text { How do you feel about what you are accomplishing in life? } \\
\text { Hogyan értékeli élete során felmutatott teljesítményét? }\end{array}$ & 1-töl 9-ig terjedő skálán \\
\hline 4. & $\begin{array}{l}\text { How do you feel about how exciting your life is? } \\
\text { Hogy látja, mennyire izgalmas az élete? }\end{array}$ & 1-től 9-ig terjedő skálán \\
\hline 5. & $\begin{array}{l}\text { How do you feel about the extent to which you are succeeding and } \\
\text { getting ahead in life? } \\
\text { Hogy látja, mennyire sikeres és képes előbbre jutni az életben? }\end{array}$ & 1-tôl 9-ig terjedő skálán \\
\hline
\end{tabular}

* Forrás: Headey-Wearing (1989).

- Az 1-es érték (,,terrible”) a teljes elégedetlenséget (borzasztó/ nagyon rossz/ egyáltalán nem), míg a 9-es (,delighted”) a teljes elégedettséget (örömteli/ nagyon jó/ teljes mértékben) jelenti.

- A skála első kérdését a kérdőív elején, majd a kérdőív végén is elhelyezték (r $=0,67$ ).

- A kérdőív végén elhelyezett kérdéssel együtt az összesen hat kérdésből átlagot számolva hozták létre az élettel való elégedettség indexét, melynek megbízhatósági együtthatója (Cronbach's Alfa) 0,92 volt.

- Az LS Index a korábbi, dieneri élettel való elégedettséget mérő skálával: Satisfaction with Life Scale erős összefüggést mutatott $(\mathrm{r}=0,70)$ (HeadeyWearing, 1989:732).

A skála a többdimenziós mérőeszközökre nyújt példát, melynek elemei között az attitűd érzelmi és racionális oldalainak mutatói is szerepelnek. Ez alapján is látható, hogy az egyes kutatások során alkalmazott, élettel való elégedettséget mérö többitemes mérőeszközökben keverednek az affektív és kognitív itemek, jóllehet arra, hogy ezek önálló, egymással nem helyettesíthető konstruktumok, számos empirikus eredményt találunk (Raibley, 2012). Támpontul szolgálhat még az a meta-analízis, amelyben 313 adatállomány eredményeit vetették össze annak érdekében, hogy az affektív és kognitív oldal különbségére rámutassanak (Luhmann et al., 2012). 


\section{F.3. A szubjektív életminőség multidimenzionális modellje és jellemzői}

\section{F.3.1. A Szubjektív Életminőség Index elemei}

F.3.1. táblázat: A szubjektív életminőség index változóinak leíró statisztikái (átlag, szórás, illetve megoszlások a teljes mintán belül*), 2006, 2012

\begin{tabular}{|c|c|c|c|c|}
\hline $\begin{array}{l}\text { Változó } \\
\text { (dimenzió) }\end{array}$ & \multicolumn{2}{|c|}{ Változó értékei } & 2006 & 2012 \\
\hline \multirow{2}{*}{$\begin{array}{l}\text { Mindent összevetve } \\
\text { mennyire elégedett } \\
\text { mostani életével? } \\
\text { („Having”) }\end{array}$} & \multirow{2}{*}{\multicolumn{2}{|c|}{$\begin{array}{l}0=\text { Teljesen elégedetlen } \\
10=\text { Teljesen elégedett }\end{array}$}} & $\mathrm{N}=1507$ & $\mathrm{~N}=1996$ \\
\hline & & & $\begin{array}{c}5,42 \\
(2,573)\end{array}$ & $\begin{array}{c}5,59 \\
(2,429)\end{array}$ \\
\hline \multirow[b]{2}{*}{$\begin{array}{l}\text { 2006: } \\
\text { Vannak olyan emberek } \\
\text { az életemben, akik } \\
\text { igazán törődnek velem. } \\
\text { 2012: } \\
\text { Milyen mértékben kap } \\
\text { segítséget és támogatást } \\
\text { az Önhöz közelállóktól, } \\
\text { amikor szüksége van rá? } \\
\text { („Loving”) }\end{array}$} & \multirow[b]{2}{*}{$\begin{array}{l}\text { 2006: } \\
\text { 1=Egyáltalán } \\
\text { nem ért egyet } \\
\text { 2=Nem ért } \\
\text { egyet } \\
\text { 3=Egyet is ért, } \\
\text { meg nem is } \\
\text { 4=Egyetért } \\
\text { 5=Teljesen } \\
\text { egyetért }\end{array}$} & \multirow[b]{2}{*}{$\begin{array}{l}2012: \\
\text { 0 - Egyáltalán } \\
\text { nem } \\
1- \\
2- \\
3- \\
4- \\
5- \\
6 \text { - Nagyon }\end{array}$} & $\mathrm{N}=1504$ & $\mathrm{~N}=2009$ \\
\hline & & & $\begin{array}{c}1,4 \\
1,9 \\
7,5 \\
42,2 \\
46,9\end{array}$ & $\begin{array}{c}0,9 \\
1,3 \\
2,6 \\
8,2 \\
13,6 \\
28,5 \\
44,9\end{array}$ \\
\hline \multirow[b]{2}{*}{$\begin{array}{l}\text { Úgy érzem, amivel } \\
\text { foglalkozom az értékes } \\
\text { és megéri a fáradtságot. } \\
\text { („Being”) }\end{array}$} & \multirow{2}{*}{\multicolumn{2}{|c|}{$\begin{array}{l}\text { 1=Egyáltalán nem ért egyet } \\
\text { 2=Nem ért egyet } \\
\text { 3=Egyet is ért, meg nem is } \\
\text { 4=Egyetért } \\
\text { 5=Teljesen egyetért }\end{array}$}} & $\mathrm{N}=1479$ & $\mathrm{~N}=1972$ \\
\hline & & & $\begin{array}{r}2,9 \\
3,6 \\
21,2 \\
46,0 \\
26,3\end{array}$ & $\begin{array}{l}3,1 \\
6,5 \\
24,4 \\
46,5 \\
19,5\end{array}$ \\
\hline \multirow{2}{*}{$\begin{array}{l}\text { Mindent egybevetve } \\
\text { mennyire érzi magát } \\
\text { boldognak? } \\
\text { (Feelings - Long-term) }\end{array}$} & \multirow{2}{*}{\multicolumn{2}{|c|}{$\begin{array}{l}0=\text { Nagyon boldogtalan } \\
10=\text { Nagyon boldog }\end{array}$}} & $\mathrm{N}=1508$ & $\mathrm{~N}=2007$ \\
\hline & & & $\begin{array}{c}6,41 \\
(2,470)\end{array}$ & $\begin{array}{c}6,10 \\
(2,254)\end{array}$ \\
\hline \multirow{2}{*}{$\begin{array}{l}\text { Pozitív-negatív érzések } \\
\text { balansza } \\
\text { (Feelings - Short-term) }\end{array}$} & \multirow{2}{*}{\multicolumn{2}{|c|}{$\begin{array}{l}-6=\text { abszolút negatív balansz } \\
+6=\text { abszolút pozitív balansz }\end{array}$}} & $\mathrm{N}=1476$ & $\mathrm{~N}=1963$ \\
\hline & & & $\begin{array}{c}1,402 \\
(2,459)\end{array}$ & $\begin{array}{c}1,462 \\
(2,333)\end{array}$ \\
\hline
\end{tabular}

*Az érvényes válaszokon belül. 


\section{F.3.2. A Szubjektív Életminőség Index és a képző változók közötti kapcsolatok}

F.3.2.a. táblázat: A szubjektív életminőség index és változóinak összefüggései, 2006 (korrelációs együtthatók, $\mathrm{N}=1433$ )

\begin{tabular}{|l|c|c|c|c|c|c|}
\hline & $\begin{array}{c}\text { Szubjektív } \\
\text { Életminőség } \\
\text { Index }\end{array}$ & „Having” & „Loving” & „Being” & Boldogság & $\begin{array}{c}\text { Pozitív- } \\
\text { negatív } \\
\text { balansz }\end{array}$ \\
\hline Sz. Émin. Index & 1 & & & & & \\
\hline „Having” & $0,783 * *$ & 1 & & & & \\
\hline „Loving” & $0,595 * *$ & $0,305 * *$ & 1 & & & \\
\hline „Being” & $0,633 * *$ & $0,334 * *$ & $0,331 * *$ & 1 & 1 & \\
\hline Boldogság & $0,822^{* *}$ & $0,623 * *$ & $0,361 * *$ & $0,349 * *$ & $0,496 * *$ & 1 \\
\hline $\begin{array}{l}\text { Pozitív-negatív } \\
\text { balansz }\end{array}$ & $0,715^{* *}$ & $0,437 * *$ & $0,252^{* *}$ & $0,333 * *$ & & \\
\hline
\end{tabular}

Megjegyzés: szignifikancia szint: **0,01 szinten szignifikáns; hiányzó esetek: Listwise.

F.3.2.b. táblázat: A szubjektív életminőség index és változóinak összefüggései, 2012 (korrelációs együtthatók, $\mathrm{N}=1905$ )

\begin{tabular}{|c|c|c|c|c|c|c|}
\hline & $\begin{array}{l}\text { Szubjektív } \\
\text { Életminőség } \\
\text { Index }\end{array}$ & „Having” & „Loving” & „Being” & Boldogság & $\begin{array}{l}\text { Pozitív- } \\
\text { negatív } \\
\text { balansz }\end{array}$ \\
\hline Sz. Émin. Index & 1 & & & & & \\
\hline „Having” & $0,783 * *$ & 1 & & & & \\
\hline „Loving” & $0,635 * *$ & $0,340 * *$ & 1 & & & \\
\hline „Being” & $0,566 * *$ & $0,237 * *$ & $0,288 * *$ & 1 & & \\
\hline Boldogság & $0,843 * *$ & $0,672 * *$ & $0,404 * *$ & $0,306 * *$ & 1 & \\
\hline $\begin{array}{l}\text { Pozitív-negatív } \\
\text { balansz }\end{array}$ & $0,759 * *$ & $0,456 * *$ & $0,341 * *$ & $0,369 * *$ & $0,538 * *$ & 1 \\
\hline
\end{tabular}

Megjegyzés: szignifikancia szint: **0,01 szinten szignifikáns; hiányzó esetek: Listwise. 


\section{F.4. A szubjektív egészség, jövedelmi helyzet és biztonságérzet változói}

F.4. táblázat: A szubjektív egészség, biztonságérzet és a szubjektív jövedelmi helyzet változóinak megoszlásai (\%), 2006, 2012

\begin{tabular}{|c|c|c|c|}
\hline $\begin{array}{l}\text { Változó } \\
\text { (jelentése) }\end{array}$ & Változó értékei & $\begin{array}{l}\text { Megoszlás a } \\
\text { teljes mintán } \\
\text { belül*, } \\
2006 \\
\text { N=1517 }\end{array}$ & $\begin{array}{l}\text { Megoszlás a } \\
\text { teljes mintán } \\
\text { belül*, } \\
2012 \\
\text { N=2013 }\end{array}$ \\
\hline $\begin{array}{l}\text { Milyen az Ön } \\
\text { általános egészségi } \\
\text { állapota? } \\
\text { (Szubjektív egészségi } \\
\text { állapot) }\end{array}$ & $\begin{array}{l}\text { 1=Nagyon rossz } \\
\text { 2=Rossz } \\
\text { 3=Kielégítő } \\
\text { 4=Jó } \\
\text { 5=Nagyon jó }\end{array}$ & $\begin{array}{c}3,5 \\
12,4 \\
36,4 \\
37,0 \\
10,8\end{array}$ & $\begin{array}{c}2,7 \\
11,0 \\
27,6 \\
42,8 \\
15,8\end{array}$ \\
\hline \multirow{2}{*}{$\begin{array}{l}\text { Mennyire biztonságos } \\
\text { ezen a környéken } \\
\text { sötétedés után egyedül } \\
\text { sétálni? } \\
\text { (Biztonságérzet) }\end{array}$} & & $\mathrm{N}=1500$ & $\mathrm{~N}=1973$ \\
\hline & $\begin{array}{l}\text { 1=Egyáltalán nem biztonságos } \\
\text { 2=Nem biztonságos } \\
\text { 3=Biztonságos } \\
\text { 4=Nagyon biztonságos }\end{array}$ & $\begin{array}{l}3,1 \\
20,3 \\
59,0 \\
17,6\end{array}$ & $\begin{array}{c}5,9 \\
22,3 \\
64,1 \\
7,8\end{array}$ \\
\hline \multirow{2}{*}{$\begin{array}{l}\text { Melyik leírás közelíti } \\
\text { meg leginkább az } \\
\text { Önök háztartásának } \\
\text { jelenlegi jövedelmi } \\
\text { helyzetét? } \\
\text { (Szubjektív jövedelmi } \\
\text { helyzet) }\end{array}$} & & $\mathrm{N}=1507$ & $\mathrm{~N}=1987$ \\
\hline & $\begin{array}{l}\text { 1=Nagyon nehezen élünk meg } \\
\text { 2=Nehezen élünk meg } \\
\text { 3=Kijövünk } \\
\text { 4=Kényelmesen megélünk }\end{array}$ & $\begin{array}{c}12,1 \\
32,4 \\
49,6 \\
5,9\end{array}$ & $\begin{array}{c}21,8 \\
34,7 \\
37,3 \\
6,2\end{array}$ \\
\hline
\end{tabular}

*Érvényes válaszokon belül.

Megjegyzés: A magyarázó változók kategóriái a fentiekhez képest részben eltérően, árnyaltabban, az alábbiak szerint kerültek összevonásra a szubjektív életminőség index elemeinek (having, loving, being, feelings of well-being) leíró statisztikáihoz:

Szubjektív egészség: rossz (1+2); kielégítő (3), jó (4+5);

Biztonságérzet: nincs biztonságérzete $(1+2)$; van biztonságérzete $(3+4)$;

Szubjektív jövedelmi helyzet: nehezen élünk meg (1+2), kijövünk (3), kényelmesen megélünk (4). 


\section{F.5. A társadalmi integráció változói}

F.5. táblázat: A társadalmi integráció hipotézis magyarázó változóinak megoszlásai (\%), 2006, 2012

\begin{tabular}{|c|c|c|c|}
\hline Változó & Változó értékei & $\begin{array}{l}\text { Megoszlás a teljes } \\
\text { mintán belül* } \\
2006\end{array}$ & $\begin{array}{l}\text { Megoszlás a teljes } \\
\text { mintán belül* } \\
2012\end{array}$ \\
\hline \multirow{7}{*}{$\begin{array}{l}\text { Családi } \\
\text { állapot** }\end{array}$} & & $\mathrm{N}=1513$ & $\mathrm{~N}=1963$ \\
\hline & Házas/élettárssal él & 59,6 & 54,5 \\
\hline & $\begin{array}{l}\text { Külön él, de jogilag } \\
\text { nős/férjezett/élettársa van }\end{array}$ & 1,8 & - \\
\hline & Elvált/felbontotta élettársi & 8,7 & 10,5 \\
\hline & Özvegy/élettársa elhunyt & 11,8 & 11,9 \\
\hline & Nötlen/hajadon & 18,1 & 23,1 \\
\hline & $\begin{array}{l}\text { Házas vagy élettárssal él } \\
\text { Egyedülálló }\end{array}$ & $\begin{array}{l}59,6 \\
40,4\end{array}$ & $\begin{array}{l}54,5 \\
45,5\end{array}$ \\
\hline \multirow{9}{*}{$\begin{array}{l}\text { Munkaerő- } \\
\text { piaci } \\
\text { jelenlét**** }\end{array}$} & & $\mathrm{N}=1382$ & $\mathrm{~N}=1994$ \\
\hline & Dolgozik & 45,4 & 46,5 \\
\hline & Diák/Tanul & 7,6 & 8,5 \\
\hline & Munkanélküli & 4,7 & 8,2 \\
\hline & Tartós beteg/rokkant & 3,9 & 3,4 \\
\hline & Nyugdíjas & 28,4 & 26,7 \\
\hline & HTB/egyéb & 10,0 & 6,7 \\
\hline & Dolgozik & 45,4 & 46,5 \\
\hline & Nem dolgozik & 54,6 & 53,5 \\
\hline
\end{tabular}

*Érvényes válaszokon belül.

**A 2006-os évben a kérdőív tartalmazott kettő, a szokásostól eltérő családi állapot kategóriát: „Külön él, de jogilag nős/férjezett” $(1,0 \% *)$, illetve „Külön él, de törvényes élettársa van” $(0,8 \% *)$, amelyeket a kutatási koncepció alapján az egyedülállókhoz soroltam. 2012-ben nem alkalmazták ezt a distinkciót a magyar kérdőívben.

*** A kérdőívben szereplő kérdés:,A következők közül mivel jellemezhető az elmúlt hét napja?”, mely változó kódolása és a duplikációt elkerülő ellenőrző kérdések alapján az adatállomány tartalmazta a teljes mintára vonatkozó tiszta (post coded) változót, a táblázatban foglaltak szerint. 


\section{F.6. Az anómia és elidegenedésérzet változói}

\section{F.6.1. Az egyéni anómiát és elidegenedésérzetet mérő mutatók leíró statisztikái}

F.5.1. táblázat: Az anómia és elidegenedés skála képző változóinak megoszlásai (\%), 2006, 2012

\begin{tabular}{|c|c|c|c|}
\hline $\begin{array}{l}\text { Változó } \\
\text { (jelentése) }\end{array}$ & Változó értékei & $\begin{array}{l}\text { Megoszlás a teljes } \\
\text { mintán belül* } \\
2006\end{array}$ & $\begin{array}{c}\text { Megoszlás a teljes } \\
\text { mintán belül* } \\
2012\end{array}$ \\
\hline \multirow[b]{2}{*}{$\begin{array}{l}\text { Legtöbbször úgy } \\
\text { érzem, hogy van } \\
\text { értelme annak, amit } \\
\text { csinálok. } \\
\text { (Értelemnélküliség) }\end{array}$} & \multirow[b]{2}{*}{$\begin{array}{l}\text { 1=Teljesen egyetért } \\
\text { 2=Egyetért } \\
3=\text { Egyet is ért, meg nem is } \\
\text { 4=Nem ért egyet } \\
5=\text { Egyáltalán nem ért egyet }\end{array}$} & $\mathrm{N}=1509$ & $\mathrm{~N}=1994$ \\
\hline & & $\begin{array}{c}26,2 \\
50,4 \\
17,4 \\
4,4 \\
1,6\end{array}$ & $\begin{array}{c}19,0 \\
46,2 \\
23,4 \\
7,9 \\
3,5\end{array}$ \\
\hline \multirow[b]{2}{*}{$\begin{array}{l}\text { A múlt héten milyen } \\
\text { gyakran érezte } \\
\text { magányosnak magát? } \\
\text { (Magányosság érzet) }\end{array}$} & \multirow[b]{2}{*}{$\begin{array}{l}\text { 1=Soha vagy szinte soha } \\
\text { 2=Néha } \\
\text { 3=Többnyire } \\
\text { 4=Mindig vagy majdnem } \\
\text { mindig }\end{array}$} & $\mathrm{N}=1505$ & $\mathrm{~N}=2000$ \\
\hline & & $\begin{array}{c}60,8 \\
24,4 \\
9,5 \\
5,3\end{array}$ & $\begin{array}{c}56,9 \\
28,0 \\
10,6 \\
4,6\end{array}$ \\
\hline $\begin{array}{l}\text { Mennyire érzi, hogy } \\
\text { segítőkészek az } \\
\text { emberek a közvetlen } \\
\text { környezetében? } \\
\text { (Izoláció) }\end{array}$ & $\begin{array}{l}1 \text { - Nagyon } \\
2- \\
3- \\
4- \\
5- \\
6- \\
7 \text { - Egyáltalán nem }\end{array}$ & $\begin{array}{c}\mathrm{N}=1503 \\
22,6 \\
24,2 \\
21,1 \\
18,9 \\
6,8 \\
2,6 \\
3,7\end{array}$ & $\begin{array}{c}\mathrm{N}=2010 \\
22,3 \\
27,4 \\
22,6 \\
16,8 \\
6,1 \\
2,6 \\
2,2\end{array}$ \\
\hline \multirow{2}{*}{$\begin{array}{l}\text { A mindennapokban } \\
\text { ritkán adódik } \\
\text { lehetőségem arra, } \\
\text { hogy megmutassam, } \\
\text { mire is vagyok képes. } \\
\text { (Haszontalanság } \\
\text { érzet) }\end{array}$} & \multirow[b]{2}{*}{$\begin{array}{l}\text { 1=Egyáltalán nem ért egyet } \\
\text { 2=Nem ért egyet } \\
\text { 3=Egyet is ért, meg nem is } \\
\text { 4=Egyetért } \\
\text { 5=Teljesen egyetért }\end{array}$} & $\mathrm{N}=1482$ & $\mathrm{~N}=1991$ \\
\hline & & $\begin{array}{c}7,4 \\
27,7 \\
34,7 \\
25,5 \\
4,8\end{array}$ & $\begin{array}{c}10,3 \\
22,8 \\
28,8 \\
32,0 \\
6,1\end{array}$ \\
\hline
\end{tabular}

*Az érvényes válaszokon belül. 


\section{F.6.2. Az anómia és elidegenedés skála jellemzői}

F.6.2.a. táblázat: Anómia és elidegenedés skála és aspektusai közötti összefüggések (korrelációs együtthatók), 2006

\begin{tabular}{|c|c|c|c|c|c|}
\hline & $\begin{array}{c}\text { Anómia- } \\
\text { elidegenedés } \\
\text { Skála }\end{array}$ & $\begin{array}{l}\text { Értelem- } \\
\text { nélküliség }\end{array}$ & $\begin{array}{l}\text { Magányosság } \\
\text { érzet }\end{array}$ & Izoláció & $\begin{array}{l}\text { Haszontalan- } \\
\text { ság érzet }\end{array}$ \\
\hline $\begin{array}{l}\text { Anómia- } \\
\text { elidegenedés Skála }\end{array}$ & 1 & & & & \\
\hline Értelemnélküliség & $0,642 * *$ & 1 & & & \\
\hline Magányosság érzet & $0,562 * *$ & $0,315^{* *}$ & 1 & & \\
\hline Izoláció & $0,736 * *$ & $0,242 * *$ & $0,166^{* *}$ & 1 & \\
\hline $\begin{array}{l}\text { Haszontalanság } \\
\text { érzet }\end{array}$ & $0,562^{* *}$ & $0,230 * *$ & $0,165^{* *}$ & $0,125^{* *}$ & 1 \\
\hline
\end{tabular}

**0,01 szinten szignifikáns;

F.6.2.b. táblázat: Anómia és elidegenedés skála és aspektusai közötti összefüggések (korrelációs együtthatók), 2012

\begin{tabular}{|l|c|c|c|c|c|}
\hline & $\begin{array}{c}\text { Anómia- } \\
\text { elidegenedés } \\
\text { Skála }\end{array}$ & $\begin{array}{c}\text { Értelem- } \\
\text { nélküliség }\end{array}$ & $\begin{array}{c}\text { Magányosság } \\
\text { érzet }\end{array}$ & Izoláció & $\begin{array}{c}\text { Haszontalan- } \\
\text { ság érzet }\end{array}$ \\
\hline $\begin{array}{l}\text { Anómia- } \\
\text { elidegenedés Skála }\end{array}$ & 1 & 1 & & & \\
\hline Értelemnélküliség & $0,668^{* *}$ & $0,318^{* *}$ & 1 & & \\
\hline Magányosság érzet & $0,583^{* *}$ & $0,306^{* *}$ & $0,230^{* *}$ & 1 & \\
\hline Izoláció & $0,745^{* *}$ & $0,133^{* *}$ & $0,153^{* *}$ & 1 \\
\hline Haszontalanság & $0,558^{* *}$ & $0,150^{* *}$ & 0,13 & & \\
\hline
\end{tabular}

** 0,01 szinten szignifikáns; 


\section{F.7. A személyes beállítottság változói}

\section{F.7.1. Az optimista-pesszimista attitüdöt mérő mutatók leíró statisztikái}

F.7.1. sz. táblázat: Az optimista-pesszimista attitüdöt mérő mutatók megoszlásai (\%), 2006, 2012

\begin{tabular}{|c|c|c|c|}
\hline Változó jelentése & Változó értékei & $\begin{array}{c}\text { Megoszlás a teljes } \\
\text { mintán belül*, } \\
2006 \\
\text { N=1506 }\end{array}$ & $\begin{array}{c}\text { Megoszlás a teljes } \\
\text { mintán belül*, } \\
2012 \\
\text { N=2004 }\end{array}$ \\
\hline $\begin{array}{l}\text { Optimistán } \\
\text { tekintek a jövőre. }\end{array}$ & $\begin{array}{l}\text { 1=Teljesen egyetért } \\
\text { 2=Egyetért } \\
3=\text { Egyet is ért, meg nem is } \\
\text { 4=Nem ért egyet } \\
\text { 5=Egyáltalán nem ért egyet }\end{array}$ & $\begin{array}{c}18,6 \\
32,8 \\
28,6 \\
14,5 \\
5,5\end{array}$ & $\begin{array}{c}13,6 \\
37,2 \\
29,0 \\
12,1 \\
8,1\end{array}$ \\
\hline & & $\mathrm{N}=1513$ & $\mathrm{~N}=2007$ \\
\hline $\begin{array}{l}\text { Általában } \\
\text { elégedett vagyok } \\
\text { magammal. }\end{array}$ & $\begin{array}{l}\text { 1=Teljesen egyetért } \\
\text { 2=Egyetért } \\
3=\text { Egyet is ért, meg nem is } \\
\text { 4=Nem ért egyet } \\
\text { 5=Egyáltalán nem ért egyet }\end{array}$ & $\begin{array}{c}14,0 \\
43,4 \\
28,4 \\
11,0 \\
3,3\end{array}$ & $\begin{array}{c}11,3 \\
44,7 \\
29,5 \\
10,0 \\
4,4\end{array}$ \\
\hline $\begin{array}{l}\text { Néha úgy érzem, } \\
\text { kész csốd } \\
\text { vagyok. }\end{array}$ & $\begin{array}{l}\text { 1=Teljesen egyetért } \\
\text { 2=Egyetért } \\
3=\text { Egyet is ért, meg nem is } \\
\text { 4=Nem ért egyet } \\
\text { 5=Egyáltalán nem ért egyet }\end{array}$ & $\begin{array}{c}\mathrm{N}=1505 \\
4,2 \\
13,3 \\
18,3 \\
38,5 \\
25,7\end{array}$ & $\begin{array}{c}\mathrm{N}=1993 \\
2,4 \\
10,9 \\
21,8 \\
36,0 \\
28,9\end{array}$ \\
\hline \multirow[b]{2}{*}{$\begin{array}{l}\text { Ha valami } \\
\text { rosszul sül el, } \\
\text { nehezen találok } \\
\text { vissza a régi } \\
\text { kerékvágásba. }\end{array}$} & & $\mathrm{N}=1505$ & $\mathrm{~N}=1993$ \\
\hline & $\begin{array}{l}\text { 1=Teljesen egyetért } \\
\text { 2=Egyetért } \\
3=\text { Egyet is ért, meg nem is } \\
\text { 4=Nem ért egyet } \\
\text { 5=Egyáltalán nem ért egyet }\end{array}$ & $\begin{array}{c}6,6 \\
22,3 \\
30,3 \\
31,2 \\
9,6\end{array}$ & $\begin{array}{c}4,7 \\
18,5 \\
29,5 \\
31,3 \\
16,0\end{array}$ \\
\hline
\end{tabular}

*Érvényes válaszokon belül. 


\section{F.7.2. Az Optimizmus-pesszimizmus Index}

F.7.2.a. táblázat: Az Optimizmus-pesszimizmus Index-képző változóinak összefüggései (korrelációs együtthatók), 2006

\begin{tabular}{|c|c|c|c|c|}
\hline & $\begin{array}{c}\text { Optimistán tekintek } \\
\text { a jövőre }\end{array}$ & $\begin{array}{c}\text { Általában elégedett } \\
\text { vagyok magammal }\end{array}$ & $\begin{array}{c}\text { Néha úgy érzem kész } \\
\text { csőd vagyok }\end{array}$ & $\begin{array}{c}\text { Halami } \\
\text { nehszul sül el, } \\
\text { vissza a régi } \\
\text { kerékvágásba }\end{array}$ \\
\hline $\begin{array}{c}\text { Optimistán tekintek a } \\
\text { jövőre }\end{array}$ & 1 & 1 & 1 & \\
\hline $\begin{array}{c}\text { Általában elégedett } \\
\text { vagyok magammal }\end{array}$ & $0,491^{* *}$ & $-0,439^{* *}$ & & \\
\hline $\begin{array}{c}\text { Néha úgy érzem kész } \\
\text { csőd vagyok }\end{array}$ & $-0,322^{* *}$ & $-0,241^{* *}$ & $0,359^{* *}$ & 1 \\
\hline $\begin{array}{c}\text { Ha valami rosszul sül } \\
\text { el, nehezen találok } \\
\text { vissza a régi } \\
\text { kerékvágásba }\end{array}$ & $-0,210^{* *}$ & & & \\
\hline
\end{tabular}

**0,01 szinten szignifikáns;

F.7.2.b. táblázat: $\mathrm{Az}$ Optimizmus-pesszimizmus Index-képző változóinak összefüggései (korrelációs együtthatók), 2012

\begin{tabular}{|c|c|c|c|c|}
\hline & $\begin{array}{c}\text { Optimistán tekintek } \\
\text { a jövőre }\end{array}$ & $\begin{array}{c}\text { Általában elégedett } \\
\text { vagyok magammal }\end{array}$ & $\begin{array}{c}\text { Néha úgy érzem kész } \\
\text { csőd vagyok }\end{array}$ & $\begin{array}{c}\text { Halami } \\
\text { nehszul sül el, } \\
\text { vissza a régi } \\
\text { kerékvágásba }\end{array}$ \\
\hline $\begin{array}{c}\text { Optimistán tekintek a } \\
\text { jövőre }\end{array}$ & 1 & 1 & 1 & \\
\hline $\begin{array}{c}\text { Általában elégedett } \\
\text { vagyok magammal }\end{array}$ & $0,580^{* *}$ & $-0,410^{* *}$ & & \\
\hline $\begin{array}{c}\text { Néha úgy érzem kész } \\
\text { csőd vagyok }\end{array}$ & $-0,298^{* *}$ & $-0,273^{* *}$ & $0,372^{* *}$ & 1 \\
\hline $\begin{array}{c}\text { Ha valami rosszul sül } \\
\text { el, nehezen találok } \\
\text { vissza a régi } \\
\text { kerékvágásba }\end{array}$ & $-0,220^{* *}$ & & & \\
\hline
\end{tabular}

**0,01 szinten szignifikáns; 
F.7.2.c. sz. táblázat: Az Optimizmus-pesszimizmus Index statisztikái, 2006, 2012

\begin{tabular}{|c|c|c|}
\hline & \multicolumn{2}{|c|}{ Korreláció az optimizmust mérő főkomponenssel } \\
\hline & $\mathbf{2 0 0 6}^{*}$ & $\mathbf{2 0 1 2}$ \\
\hline Optimistán tekintek a jövőre. & 0,718 & 0,746 \\
\hline Általában elégedett vagyok magammal. & 0,791 & 0,815 \\
\hline Néha úgy érzem kész csőd vagyok. & $-0,753$ & $-0,717$ \\
\hline $\begin{array}{c}\text { Ha valami rosszul sül el, nehezen találok vissza a } \\
\text { régi kerékvágásba. }\end{array}$ & $-0,585$ & $-0,602$ \\
\hline Sajátérték & $\mathbf{2 , 0 5 1}$ & $\mathbf{2 , 0 9 6}$ \\
\hline Négyzetes faktorsúlyok összege & $\mathbf{5 1 , 2 7 5}$ & $\mathbf{5 2 , 3 9 8}$ \\
\hline
\end{tabular}

*KMO=0,684; Bartlett-teszt: Chi-Sq. =987,982; df=6, Sign. $=, 000$

$* * \mathrm{KMO}=0,663$; Bartlett-teszt: Chi-Sq.=1524,448; df=6, Sign.=,000

A Kaiser-Meyer-Olkin mutató a főkomponens-elemzés legfontosabb statisztikája. A szakirodalom szerint a KMO értéke az alábbi kategóriák között fogadható el: „0.9 $\leq \mathrm{KMO}$ nagyon jó; $0.8 \leq \mathrm{KMO}<0.9$ jó; $0.7 \leq \mathrm{KMO}<0.8$ közepes; $\mathbf{0 . 6} \leq \mathrm{KMO}<\mathbf{0 . 7}$ gyenge; $0.5 \leq \mathrm{KMO}<0.6$ rossz; $0.5<\mathrm{KMO}$ elfogadhatatlan" (Füstös, 2010:253). Az indexképző változók közötti korreláció az alapfeltétele az elemzési eljárásnak, mely az F.7.2.a-b.sz. táblázatok alapján néhány esetben erősebb, néhány esetben gyengébb összefüggést mutatott. Összességében az index használatát elvetettem, annak ellenére, hogy a Bartlett-teszt szignifikáns volt, ugyanis a KMO kritérium teljesülése fontosabb feltétele a fökomponens-analízisnek, mivel a modell illeszkedését ez mutatja meg: „A KMO-mutató értéktartománya 0 és 1 között van. Közelebb esik 1hez akkor, amikor a fókomponens modell illeszkedik az adatokhoz"(Füstös, 2010:254). 


\section{F.8. A kontrollváltozók leíró statisztikái}

F.8. táblázat: A kontrollváltozók leíró statisztikái [százalékos megoszlások; egy före jutó jövedelemnél: átlag (szórás)], 2006, 2012

\begin{tabular}{|c|c|c|c|c|}
\hline Változó & \multicolumn{2}{|c|}{ Változó értékei } & $\begin{array}{l}\text { Megoszlás a teljes } \\
\text { mintán belül* } \\
\mathbf{2 0 0 6}\end{array}$ & $\begin{array}{c}\text { Megoszlás a teljes mintán } \\
\text { belül* } \\
\mathbf{2 0 1 2}\end{array}$ \\
\hline \multirow[b]{2}{*}{ Nem } & \multirow{2}{*}{\multicolumn{2}{|c|}{$\begin{array}{l}\text { 1=Férfi } \\
2=\text { Nó }\end{array}$}} & $\mathrm{N}=1518$ & $\mathrm{~N}=2014$ \\
\hline & & & $\begin{array}{l}42,7 \\
57,3\end{array}$ & $\begin{array}{l}44,9 \\
55,1\end{array}$ \\
\hline \multirow[b]{2}{*}{ Életkor } & \multirow{2}{*}{\multicolumn{2}{|c|}{$\begin{array}{l}30 \text { év alatt } \\
30-39 \text { éves } \\
40-49 \text { éves } \\
50-59 \text { éves } \\
60-69 \text { éves } \\
70 \text { éves vagy idősebb }\end{array}$}} & $\mathrm{N}=1511$ & $\mathrm{~N}=2014$ \\
\hline & & & $\begin{array}{l}25,2 \\
14,9 \\
20,2 \\
16,0 \\
13,7 \\
10,0\end{array}$ & $\begin{array}{l}20,3 \\
17,0 \\
18,7 \\
16,5 \\
14,0 \\
13,5\end{array}$ \\
\hline \multirow[b]{2}{*}{ Településtípus } & \multirow{2}{*}{\multicolumn{2}{|c|}{$\begin{array}{l}\text { 1=Nagyváros és elővárosa } \\
\text { 2=Város vagy kisváros } \\
\text { 3=Falu-község-tanya }\end{array}$}} & $\mathrm{N}=1517$ & $\mathrm{~N}=2011$ \\
\hline & & & $\begin{array}{l}24,2 \\
37,2 \\
38,6\end{array}$ & $\begin{array}{l}28,9 \\
36,0 \\
35,1\end{array}$ \\
\hline \multirow[b]{2}{*}{$\begin{array}{l}\text { Iskolai } \\
\text { végzettség }\end{array}$} & \multirow{2}{*}{\multicolumn{2}{|c|}{$\begin{array}{l}\text { 1=Alapfokú vagy kevesebb } \\
\text { 2=Szakmunkás } \\
\text { 3=Érettségi } \\
\text { 4=Felsőfokú }\end{array}$}} & $\mathrm{N}=1515$ & $\mathrm{~N}=2008$ \\
\hline & & & $\begin{array}{l}34,3 \\
25,6 \\
25,3 \\
14,8\end{array}$ & $\begin{array}{l}23,6 \\
26,6 \\
31,7 \\
18,1\end{array}$ \\
\hline \multirow[b]{2}{*}{$\begin{array}{l}\text { Háztartás } \\
\text { nettó havi } \\
\text { bevétele }\end{array}$} & 2006 & 2012 & $\mathrm{~N}=1253$ & $\mathrm{~N}=1422$ \\
\hline & $\begin{array}{l}13=500 \mathrm{e} F t \text { fölött } \\
12=375-500 \mathrm{e} \mathrm{Ft} \\
11=300-375 \mathrm{e} \mathrm{Ft} \\
10=225-300 \mathrm{e} \mathrm{Ft} \\
9=200-225 \mathrm{e} \mathrm{Ft} \\
8=175-200 \mathrm{e} \mathrm{Ft} \\
7=150-175 \mathrm{e} \mathrm{Ft} \\
6=125-150 \mathrm{e} \mathrm{Ft} \\
5=100-125 \mathrm{e} \mathrm{Ft} \\
4=75-100 \mathrm{e} \mathrm{Ft} \\
3=56-75 \mathrm{e} \mathrm{Ft} \\
2=37-56 \mathrm{e} \mathrm{Ft} \\
1=37 \mathrm{e} \mathrm{Ft} \mathrm{alatt}\end{array}$ & $\begin{array}{l}10=280 \mathrm{e} F t \text { fölött } \\
9=250-280 \mathrm{e} \mathrm{Ft} \\
8=200-250 \mathrm{e} \mathrm{Ft} \\
7=175-200 \mathrm{e} \mathrm{Ft} \\
6=160-175 \mathrm{e} \mathrm{Ft} \\
5=135-160 \mathrm{e} \mathrm{Ft} \\
4=110-135 \mathrm{e} \mathrm{Ft} \\
3=90-110 \mathrm{e} \mathrm{Ft} \\
2=72-90 \mathrm{e} \mathrm{Ft} \\
1=72 \mathrm{e} \mathrm{Ft} \mathrm{alatt}\end{array}$ & $\begin{array}{c}0,3 \\
0,8 \\
2,3 \\
6,2 \\
6,8 \\
10,7 \\
10,5 \\
15,2 \\
13,0 \\
14,4 \\
11,7 \\
5,8 \\
2,4\end{array}$ & $\begin{array}{c}7,9 \\
7,3 \\
9,3 \\
10,0 \\
9,8 \\
13,0 \\
13,2 \\
11,4 \\
9,7 \\
8,4\end{array}$ \\
\hline \multirow[b]{2}{*}{$\begin{array}{l}\text { Egy före jutó } \\
\text { nettó havi } \\
\text { háztartási } \\
\text { jövedelem** }\end{array}$} & \multirow{2}{*}{\multicolumn{2}{|c|}{$\begin{array}{l}\operatorname{Min}_{\cdot 2006}=4.111,11 \\
\operatorname{Max}_{2006}=212.501,00 \\
\operatorname{Min} \cdot 2012=10.125,13 \\
\operatorname{Max} \cdot 2012=280.001,00\end{array}$}} & $\mathrm{~N}=1252$ & $\mathrm{~N}=1422$ \\
\hline & & & $\begin{array}{c}51.896,75 \\
(27.279,61)\end{array}$ & $\begin{array}{c}73.733,91 \\
(43.598,45)\end{array}$ \\
\hline
\end{tabular}

*Az érvényes válaszokon belül.

**Az egy före jutó havi nettó háztartási jövedelmet a jövedelem kategória-átlagainak és a háztartásban élők számának hányadosa alapján számoltam. A jövedelemváltozók megoszlásait lásd az F.8.a. sz. és az F.8.b. sz. ábrákon. 
F.8.a. sz. ábra: Az egy före jutó havi nettó háztartási jövedelem változó eloszlása, 2006

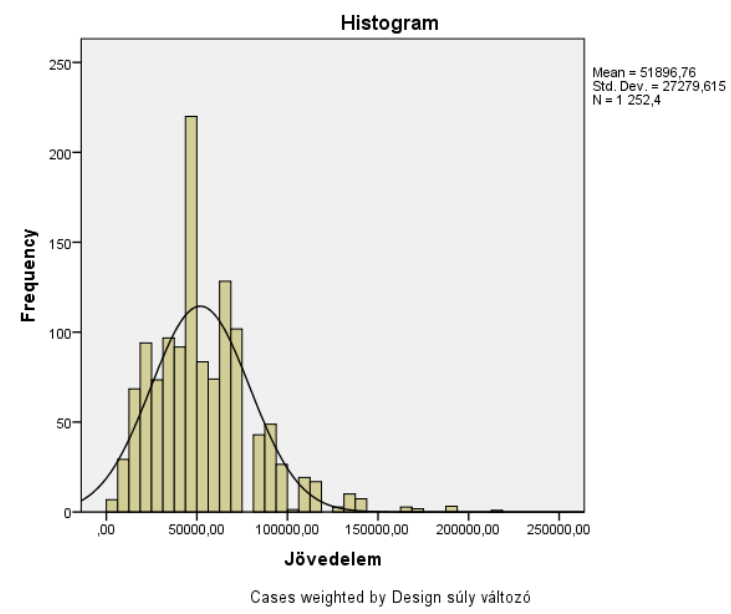

F.8.b. sz. ábra: Az egy före jutó havi nettó háztartási jövedelem változó eloszlása, 2012

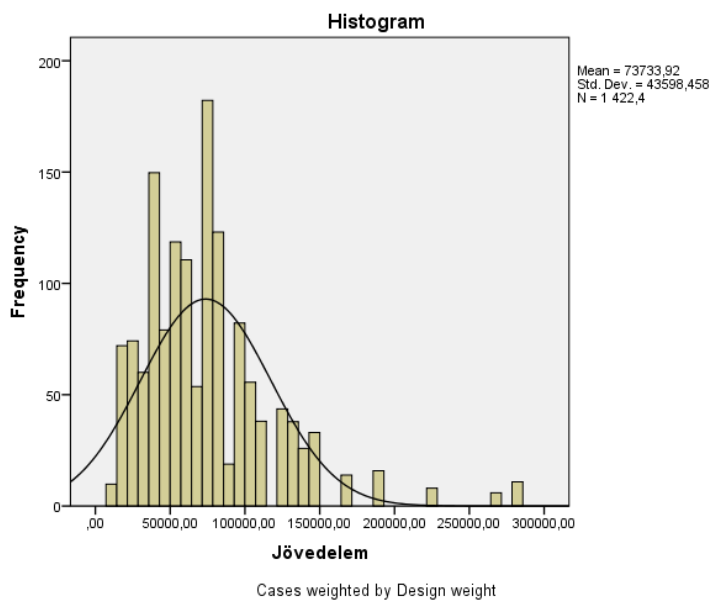




\section{F.9. A szubjektív életminőség dimenzióinak jellemzői}

\section{F.9.1.a-b. Az élettel való elégedettség és a szocio-demográfiai jellemzők összefüggése - arányok összehasonlítása}

F.9.1.a. táblázat: Az életükkel elégedettek és az elégedetlenek aránya az egyes társadalmi-demográfiai és szubjektív változókategóriák szerint, 2006

\begin{tabular}{|c|c|c|c|c|c|}
\hline & & \multicolumn{2}{|c|}{ Elégedettek } & \multicolumn{2}{|c|}{ Elégedetlenek } \\
\hline & $\mathrm{N}$ & Valid $\%$ & Phi/ Cramer's V & Valid\% & Phi/ Cramer's V \\
\hline Minta & 1516 & 62,5 & & 17,5 & \\
\hline Férfi & 648 & 64,4 & & 17,7 & \\
\hline Nő & 867 & 61,0 & & 17,2 & \\
\hline 30 év alatt & 379 & 72,3 & \multirow{6}{*}{$0,129 * * *$} & 12,7 & \\
\hline 30-39 éves & 225 & 56,4 & & 17,4 & \\
\hline 40-49 éves & 306 & 61,4 & & 17,7 & \\
\hline 50-59 éves & 242 & 56,6 & & 19,8 & \\
\hline 60-69 éves & 207 & 58,0 & & 21,6 & \\
\hline 70 éves és idősebb & 150 & 65,3 & & 18,7 & \\
\hline Nagyváros és elővárosa & 367 & 63,2 & & 18,9 & \\
\hline Város vagy kisváros & 564 & 62,6 & & 16,7 & \\
\hline Falu/község/tanya & 584 & 61,8 & & 17,3 & \\
\hline Alapfokú vagy kevesebb & 519 & 58,4 & \multirow{4}{*}{$0,180 * * *$} & 21,4 & \multirow{4}{*}{$0,130 * * *$} \\
\hline Szakmunkás & 386 & 52,8 & & 21,0 & \\
\hline Érettségi & 383 & 68,7 & & 13,6 & \\
\hline Felsőfokú & 225 & 78,2 & & 8,5 & \\
\hline Házas vagy élettárssal él & 901 & 65,4 & \multirow{2}{*}{$0,072 * *$} & 14,1 & \multirow{2}{*}{$0,106 * * *$} \\
\hline Egyedülálló & 611 & 58,3 & & 22,3 & \\
\hline Dolgozik & 743 & 65,5 & \multirow{2}{*}{$0,082 * *$} & 15,1 & \multirow{2}{*}{$0,70 * *$} \\
\hline Nem dolgozik & 636 & 57,5 & & 20,4 & \\
\hline $\begin{array}{c}\text { Egy före jutó havi nettó háztartási } \\
\text { jövedelem: } \\
\text { átlag felett }\end{array}$ & 572 & 71,1 & \multirow[t]{2}{*}{$0,165 * * *$} & 11,6 & \multirow[t]{2}{*}{$0,157 * * *$} \\
\hline átlag alatt & 680 & 55,1 & & 23,7 & \\
\hline $\begin{array}{c}\text { Elidegenedés skála: } \\
\text { átlag alatt }\end{array}$ & 821 & 76,5 & \multirow[t]{2}{*}{$0,325 * * *$} & 7,8 & \multirow[t]{2}{*}{$0,288 * * *$} \\
\hline átlag felett & 636 & 44,8 & & 29,8 & \\
\hline $\begin{array}{l}\text { Személyes beállítottság: } \\
\text { optimista }\end{array}$ & 803 & 77,7 & \multirow{2}{*}{$0,331 * * *$} & 7,5 & \multirow{2}{*}{$0,285^{* * * *}$} \\
\hline pesszimista & 683 & 45,7 & & 29,1 & \\
\hline $\begin{array}{c}\text { Szubj. egészségi állapot: rossz és } \\
\text { nagyon rossz }\end{array}$ & 241 & 38,6 & \multirow{3}{*}{$0,261 * * *$} & 37,3 & \multirow{3}{*}{$0,241 * * *$} \\
\hline kielégítő & 549 & 58,1 & & 17,3 & \\
\hline jó és nagyon jó & 724 & 73,9 & & 10,9 & \\
\hline Nincs biztonságérzete & 350 & 50,6 & \multirow{2}{*}{$0,136 * * *$} & 25,7 & \multirow{2}{*}{$0,120 * * * *$} \\
\hline Van biztonságérzete & 1147 & 66,2 & & 15,0 & \\
\hline $\begin{array}{l}\text { Szubj. jövedelmi helyzet: } \\
\text { nagyon nehezen élünk meg }\end{array}$ & 182 & 31,3 & \multirow{4}{*}{$0,306 * * *$} & 43,4 & \multirow{4}{*}{$0,297 * * *$} \\
\hline ...nehezen élünk meg & 488 & 54,5 & & 21,9 & \\
\hline ...kijövünk & 746 & 72,3 & & 9,1 & \\
\hline ...kényelmesen megélünk & 89 & 86,5 & & 9,1 & \\
\hline
\end{tabular}

$*=0,05 ; * *=0,01 ; * * *=0,001$ szinten szignifikáns. 
F.9.1.b. táblázat: Az életükkel elégedettek és az elégedetlenek aránya az egyes társadalmi-demográfiai és szubjektív változókategóriák szerint, 2012

\begin{tabular}{|c|c|c|c|c|c|}
\hline & & \multicolumn{2}{|c|}{ Elégedettek } & \multicolumn{2}{|c|}{ Elégedetlenek } \\
\hline & $\mathrm{N}$ & Valid $\%$ & $\begin{array}{c}\text { Phi/ Cramer's } \\
\text { V }\end{array}$ & Valid\% & $\begin{array}{c}\text { Phi/ Cramer's } \\
\text { V }\end{array}$ \\
\hline Minta & 1996 & 54,4 & & 30,2 & \\
\hline Férfi & 895 & 54,2 & & 31,1 & \\
\hline Nő & 1100 & 54,6 & & 29,4 & \\
\hline 30 év alatt & 406 & 63,8 & \multirow{6}{*}{$0,103 * * *$} & 20,7 & \multirow{6}{*}{$0,124 * * *$} \\
\hline 30-39 éves & 341 & 54,5 & & 29,0 & \\
\hline 40-49 éves & 373 & 52,3 & & 35,1 & \\
\hline 50-59 éves & 330 & 48,2 & & 37,6 & \\
\hline 60-69 éves & 278 & 52,2 & & 30,6 & \\
\hline 70 éves és idősebb & 268 & 53,0 & & 29,9 & \\
\hline Nagyváros és elővárosa & 578 & 62,8 & \multirow{3}{*}{$0,116^{* * * *}$} & 25,8 & \multirow{3}{*}{$0,080 * *$} \\
\hline Város vagy kisváros & 719 & 53,5 & & 29,2 & \\
\hline Falu/község/tanya & 698 & 48,4 & & 34,9 & \\
\hline Alapfokú vagy kevesebb & 470 & 43,0 & \multirow{4}{*}{$0,209 * * *$} & 37,7 & \multirow{4}{*}{$0,168 * * *$} \\
\hline Szakmunkás & 529 & 47,6 & & 36,1 & \\
\hline Érettségi & 631 & 58,5 & & 27,1 & \\
\hline Felsőfokú & 362 & 72,7 & & 16,6 & \\
\hline Házas vagy élettárssal él & 867 & 56,6 & & 29,2 & \\
\hline Egyedülálló & 1080 & 52,7 & & 31,0 & \\
\hline Dolgozik & 910 & 59,6 & \multirow{2}{*}{$0,100 * * * *$} & 24,9 & \multirow{2}{*}{$0,109 * * *$} \\
\hline Nem dolgozik & 1068 & 49,5 & & 35,0 & \\
\hline $\begin{array}{c}\text { Egy fơre jutó havi nettó } \\
\text { háztartási jövedelem: } \\
\text { átlag felett }\end{array}$ & 628 & 57,3 & \multirow[t]{2}{*}{$0,086 * * *$} & 25,3 & \multirow[t]{2}{*}{$0,118 * * *$} \\
\hline átlag alatt & 786 & 48,7 & & 36,4 & \\
\hline $\begin{array}{c}\text { Elidegenedés skála: } \\
\text { átlag alatt }\end{array}$ & 982 & 69,6 & \multirow[t]{2}{*}{$0,295 * * *$} & 17,1 & \multirow[t]{2}{*}{$0,281 * * *$} \\
\hline átlag felett & 965 & 40,2 & & 42,9 & \\
\hline $\begin{array}{c}\text { Személyes beállítottság: } \\
\text { optimista }\end{array}$ & 1053 & 70,7 & \multirow{2}{*}{$0,345^{* * *}$} & 16,1 & \multirow{2}{*}{$0,329 * * *$} \\
\hline pesszimista & 905 & 36,2 & & 46,3 & \\
\hline $\begin{array}{c}\text { Szubj. egészségi állapot: rossz } \\
\text { és nagyon rossz }\end{array}$ & 273 & 29,7 & \multirow{3}{*}{$0,271 * * *$} & 54,6 & \multirow{3}{*}{$0,291 * * *$} \\
\hline kielégítő & 553 & 43,9 & & 40,7 & \\
\hline jó és nagyon jó & 1171 & 65,2 & & 19,6 & \\
\hline Nincs biztonságérzete & 552 & 45,8 & \multirow{2}{*}{$0,110 * * *$} & 35,9 & \multirow{2}{*}{$0,079 * * *$} \\
\hline Van biztonságérzete & 1404 & 68,0 & & 27,9 & \\
\hline $\begin{array}{c}\text { Szubj. jövedelmi helyzet: } \\
\text { nagyon nehezen élünk meg }\end{array}$ & 429 & 26,1 & \multirow{4}{*}{$0,380 * * *$} & 57,2 & \multirow{4}{*}{$0,363 * * *$} \\
\hline ...nehezen élünk meg & 682 & 48,4 & & 33,7 & \\
\hline ...kijövünk & 737 & 70,7 & & 15,7 & \\
\hline ...kényelmesen megélünk & 123 & 88,6 & & 5,7 & \\
\hline
\end{tabular}

$*=0,05 ; * *=0,01 ; * * *=0,001$ szinten szignifikáns. 


\section{F.9.2. A Loving dimenzió és a szocio-demográfiai jellemzők kapcsolata - arányok összehasonlítása}

F.9.2.a. táblázat: A támogatottságérzettel rendelkezők és nem rendelkezők aránya az egyes társadalmi-demográfiai és szubjektív változókategóriák szerint, 2006

\begin{tabular}{|c|c|c|c|c|c|}
\hline & & \multicolumn{2}{|c|}{ Van támogatottságérzete } & \multicolumn{2}{|c|}{ Nincs támogatottságérzete } \\
\hline & $\mathrm{N}$ & Valid\% & Phi/ Cramer's V & Valid\% & Phi/ Cramer's V \\
\hline Minta & 1504 & 89,1 & & 3,3 & \\
\hline Férfi & 639 & 88,7 & & & \\
\hline Nő & 864 & 89,5 & & & \\
\hline 30 év alatt & 376 & 96,0 & \multirow{6}{*}{$0.131 * * *$} & & \\
\hline 30-39 éves & 222 & 88,7 & & & \\
\hline 40-49 éves & 303 & 86,1 & & & \\
\hline 50-59 éves & 238 & 87,0 & & & \\
\hline 60-69 éves & 207 & 87,4 & & & \\
\hline 70 éves és idősebb & 149 & 85,2 & & & \\
\hline Nagyváros és elővárosa & 365 & 89,9 & & & \\
\hline Város vagy kisváros & 563 & 91,1 & & & \\
\hline Falu/község/tanya & 576 & 86,8 & & & \\
\hline Alapfokú vagy kevesebb & 512 & 85,5 & \multirow{4}{*}{$0,112 * * *$} & 6,3 & \multirow{4}{*}{$0,120 * * *$} \\
\hline Szakmunkás & 384 & 87,8 & & 2,6 & \\
\hline Érettségi & 382 & 92,4 & & 1,3 & \\
\hline Felsőfokú & 223 & 94,6 & & 1,3 & \\
\hline Házas vagy élettárssal él & 894 & 90,5 & \multirow{2}{*}{$0,051^{*}$} & & \\
\hline Egyedülálló & 606 & 87,3 & & & \\
\hline Dolgozik & 741 & 91,8 & \multirow{2}{*}{$0,106^{* * *}$} & 1,9 & \multirow{2}{*}{$0,092 * * *$} \\
\hline Nem dolgozik & 628 & 85,0 & & 5,2 & \\
\hline $\begin{array}{c}\text { Egy före jutó havi nettó háztartási } \\
\text { jövedelem: } \\
\text { átlag felett }\end{array}$ & 570 & 91,8 & \multirow[t]{2}{*}{$0,077^{* *}$} & 2,3 & \\
\hline átlag alatt & 674 & $\begin{array}{l}1,0 \\
86,9 \\
\end{array}$ & & 4,2 & \\
\hline $\begin{array}{c}\text { Elidegenedés skála: } \\
\text { átlag alatt }\end{array}$ & 821 & 97,2 & \multirow[t]{2}{*}{$0,290 * * *$} & 1,1 & \multirow[t]{2}{*}{$0,135^{* * *}$} \\
\hline átlag felett & 633 & 79,1 & & 5,8 & \\
\hline $\begin{array}{c}\text { Személyes beállítottság: } \\
\text { optimista }\end{array}$ & 801 & 93,3 & \multirow{2}{*}{$0,140^{* * *}$} & 2,1 & \multirow{2}{*}{$0,069^{* *}$} \\
\hline pesszimista & 680 & 84,6 & & 4,6 & \\
\hline $\begin{array}{c}\text { Szubj. egészségi állapot: rossz és } \\
\text { nagyon rossz }\end{array}$ & 240 & 77,5 & \multirow{3}{*}{$0,180, * * *$} & 7,9 & \multirow{3}{*}{$0,112 * * *$} \\
\hline kielégítő & 545 & 88,4 & & 3,1 & \\
\hline Jó és nagyon jó & 716 & 93,6 & & 2,1 & \\
\hline Nincs biztonságérzete & 349 & 86,5 & & 4,6 & \\
\hline Van biztonságérzete & 1138 & 90,0 & & 2,9 & \\
\hline $\begin{array}{l}\text { Szubj. jövedelmi helyzet: } \\
\text { nagyon nehezen élünk meg }\end{array}$ & 181 & 74,0 & \multirow{4}{*}{$0,186^{* * *}$} & 12,2 & \multirow{4}{*}{$0,190 * * *$} \\
\hline ...nehezen élünk meg & 486 & 89,1 & & 3,1 & \\
\hline ...kijövünk & 741 & 92,2 & & 1,5 & \\
\hline ...kényelmesen megélünk & 86 & 94,2 & & 1,2 & \\
\hline
\end{tabular}

$*=0,05 ; * *=0,01 ; * * *=0,001$ szinten szignifikáns. 
F.9.2.b. táblázat: A támogatottságérzettel rendelkezők és nem rendelkezők aránya az egyes társadalmi-demográfiai és szubjektív változókategóriák szerint, 2012

\begin{tabular}{|c|c|c|c|c|c|}
\hline & & \multicolumn{2}{|c|}{ Van támogatottságérzete } & \multicolumn{2}{|c|}{ Nincs támogatottságérzete } \\
\hline & $\mathrm{N}$ & Valid\% & Phi/Cramer's V & Valid\% & Phi/Cramer's V \\
\hline Minta & 2009 & 87,0 & & 4,9 & \\
\hline Férfi & 902 & 85,5 & & & \\
\hline Nő & 1106 & 88,2 & & & \\
\hline 30 év alatt & 409 & 92,4 & \multirow{6}{*}{$0,083^{*}$} & & \\
\hline 30-39 éves & 341 & 86,2 & & & \\
\hline 40-49 éves & 377 & 85,1 & & & \\
\hline $50-59$ éves & 332 & 85,8 & & & \\
\hline 60-69 éves & 280 & 85,0 & & & \\
\hline 70 éves és idősebb & 270 & 85,6 & & & \\
\hline Nagyváros és elővárosa & 580 & 83,6 & \multirow{3}{*}{$0,066^{*}$} & & \\
\hline Város vagy kisváros & 723 & 88,9 & & & \\
\hline Falu/község/tanya & 704 & 87,9 & & & \\
\hline Alapfokú vagy kevesebb & 473 & 82,9 & \multirow{4}{*}{$0,132 * * *$} & 7,8 & \multirow{4}{*}{$0,119 * * *$} \\
\hline Szakmunkás & 534 & 82,8 & & 6,9 & \\
\hline Érettségi & 633 & 89,9 & & 2,5 & \\
\hline Felsőfokú & 364 & 93,7 & & 1,9 & \\
\hline Házas vagy élettárssal él & 873 & 89,0 & \multirow{2}{*}{$0,056^{*}$} & 3,6 & \multirow{2}{*}{$0,056^{*}$} \\
\hline Egyedülálló & 1086 & 85,2 & & 6,0 & \\
\hline Dolgozik & 915 & 89,5 & \multirow{2}{*}{$0,068^{* *}$} & 2,5 & \multirow{2}{*}{$0,099 * * *$} \\
\hline Nem dolgozik & 1075 & 84,9 & & 6,8 & \\
\hline $\begin{array}{c}\text { Egy före jutó havi nettó háztartási } \\
\text { jövedelem: } \\
\text { átlag felett }\end{array}$ & $\begin{array}{l}631 \\
788\end{array}$ & $\begin{array}{l}84,5 \\
87,4\end{array}$ & & $\begin{array}{l}4,0 \\
5,2\end{array}$ & \\
\hline $\begin{array}{c}\text { Elidegenedés skála: } \\
\text { átlag alatt }\end{array}$ & 989 & 95,9 & \multirow[t]{2}{*}{$0,265 * * *$} & 1,6 & \multirow[t]{2}{*}{$0,150 * * *$} \\
\hline átlag felett & 971 & 78,1 & & 8,0 & \\
\hline $\begin{array}{l}\text { Személyes beállítottság: } \\
\text { optimista }\end{array}$ & 1055 & 92,6 & \multirow{2}{*}{$0,177 * * *$} & 2,7 & \multirow{2}{*}{$0,100 * * *$} \\
\hline pesszimista & 913 & 80,7 & & 7,0 & \\
\hline $\begin{array}{c}\text { Szubj. egészségi állapot: rossz és } \\
\text { nagyon rossz }\end{array}$ & 277 & 76,5 & \multirow{3}{*}{$0,133 * * *$} & 11,6 & \multirow{3}{*}{$0,128^{* * * *}$} \\
\hline kielégítő & 554 & 86,1 & & 4,9 & \\
\hline Jó és nagyon jó & 1177 & 89,8 & & 3,3 & \\
\hline Nincs biztonságérzete & 555 & 82,7 & \multirow{2}{*}{$0,078 * * *$} & 6,7 & \multirow{2}{*}{$0,050^{*}$} \\
\hline Van biztonságérzete & 1414 & 88,5 & & 4,2 & \\
\hline $\begin{array}{l}\text { Szubj. jövedelmi helyzet: } \\
\text { nagyon nehezen élünk meg }\end{array}$ & 431 & 74,5 & \multirow{4}{*}{$0,207 * * *$} & 12,0 & \multirow{4}{*}{$0,183 * * *$} \\
\hline ...nehezen élünk meg & 687 & 88,4 & & 3,3 & \\
\hline ...kijövünk & 740 & 91,8 & & 2,3 & \\
\hline ...kényelmesen megélünk & 123 & 95,9 & & 1,6 & \\
\hline
\end{tabular}




\section{F.9.3. A Being dimenzió és a szocio-demográfiai jellemzők közötti összefüggések - arányok összehasonlítása}

F.9.3.a. táblázat: Az önmegvalósítók és az önmegvalósítás hiányát érzők aránya az egyes társadalmi-demográfiai és szubjektív változókategóriák szerint, 2006

\begin{tabular}{|c|c|c|c|c|c|}
\hline & & \multicolumn{2}{|c|}{ Önmegvalósítók } & \multicolumn{2}{|c|}{ Önmegvalósítás hiányát érzők } \\
\hline & $\mathrm{N}$ & Valid\% & Phi/ Cramer's V & Valid\% & Phi/ Cramer's V \\
\hline Minta & 1479 & 72,3 & & 6,5 & \\
\hline Férfi & 633 & 70,0 & & & \\
\hline Nő & 846 & 74,0 & & & \\
\hline 30 év alatt & 373 & 75,6 & \multirow{6}{*}{$0,096^{*}$} & & \\
\hline 30-39 éves & 219 & 73,1 & & & \\
\hline 40-49 éves & 304 & 75,7 & & & \\
\hline 50-59 éves & 237 & 67,9 & & & \\
\hline 60-69 éves & 201 & 72,1 & & & \\
\hline 70 éves és idősebb & 139 & 61,9 & & & \\
\hline Nagyváros és elővárosa & 358 & 70,1 & & & \\
\hline Város vagy kisváros & 556 & 73,0 & & & \\
\hline Falu/község/tanya & 565 & 72,7 & & & \\
\hline Alapfokú vagy kevesebb & 499 & 65,3 & \multirow{4}{*}{$0,167 * * *$} & 9,8 & \multirow{4}{*}{$0,114 * * *$} \\
\hline Szakmunkás & 381 & 68,5 & & 7,1 & \\
\hline Érettségi & 375 & 76,5 & & 3,2 & \\
\hline Felsőfokú & 224 & 86,6 & & 3,6 & \\
\hline Házas vagy élettárssal él & 886 & 76,0 & \multirow{2}{*}{$0,101 * * *$} & 5,0 & \multirow{2}{*}{$0,077^{* *}$} \\
\hline Egyedülálló & 589 & 66,7 & & 8,8 & \\
\hline Dolgozik & 741 & 74,5 & & 4,2 & \multirow{2}{*}{$0,110 * * *$} \\
\hline Nem dolgozik & 608 & 69,9 & & 9,7 & \\
\hline $\begin{array}{c}\text { Egy före jutó havi nettó háztartási } \\
\text { jövedelem: } \\
\text { átlag felett }\end{array}$ & 564 & 74,1 & \multirow[t]{2}{*}{$0,061^{*}$} & 5,1 & \multirow[t]{2}{*}{$0,068^{*}$} \\
\hline átlag alatt & 659 & 68,6 & & 8,6 & \\
\hline $\begin{array}{l}\text { Elidegenedés skála: } \\
\text { átlag alatt }\end{array}$ & 811 & 87,2 & \multirow[t]{2}{*}{$0,380 * * *$} & 1,7 & \multirow{2}{*}{$0,220 * * *$} \\
\hline átlag felett & 618 & 52,9 & & 12,6 & \\
\hline $\begin{array}{c}\text { Személyes beállítottság: } \\
\text { optimista }\end{array}$ & & & \multirow{3}{*}{$0,290 * * *$} & & \multirow{3}{*}{$0,166 * * *$} \\
\hline & 792 & 84,5 & & 2,5 & \\
\hline pesszimista & 663 & 58,5 & & 10,6 & \\
\hline $\begin{array}{c}\text { Szubj. egészségi állapot: rossz és nagyon } \\
\text { rossz }\end{array}$ & 228 & 50,9 & \multirow{3}{*}{$0,215^{* * *}$} & 16,7 & \multirow{3}{*}{$0,175^{* * *}$} \\
\hline kielégítő & 538 & 72,1 & & 5,2 & \\
\hline Jó és nagyon jó & 712 & 79,1 & & 4,4 & \\
\hline Nincs biztonságérzete & 340 & 63,8 & \multirow{2}{*}{$0,104 * * *$} & 8,5 & \\
\hline Van biztonságérzete & 1125 & 74,8 & & 6,0 & \\
\hline $\begin{array}{l}\text { Szubj. jövedelmi helyzet: } \\
\text { nagyon nehezen élünk meg }\end{array}$ & 171 & 55,6 & \multirow{4}{*}{$0,183 * * *$} & 22,2 & \multirow{4}{*}{$0,241 * * *$} \\
\hline ...nehezen élünk meg & 475 & 66,7 & & 6,3 & \\
\hline ...kijövünk & 735 & 79,0 & & 2,9 & \\
\hline ...kényelmesen megélünk & 88 & 77,3 & & 8,0 & \\
\hline
\end{tabular}

$*=0,05 ; * *=0,01 ; * * *=0,001$ szinten szignifikáns. 
F.9.3.b. táblázat: Az önmegvalósítók és az önmegvalósítás hiányát érzők aránya az egyes társadalmi-demográfiai és szubjektív változókategóriák szerint, 2012

\begin{tabular}{|c|c|c|c|c|c|}
\hline & & \multicolumn{2}{|c|}{ Önmegvalósítók } & \multicolumn{2}{|c|}{ Önmegvalósítás hiányát érzők } \\
\hline & $\mathrm{N}$ & Valid\% & Phi/Cramer's V & Valid\% & Phi/ Cramer's V \\
\hline Minta & 1972 & 66,0 & & 9,6 & \\
\hline Férfi & 884 & 65,4 & & & \\
\hline Nő & 1089 & 66,5 & & & \\
\hline 30 év alatt & 404 & 65,3 & \multirow{6}{*}{$0,144 * * *$} & 9,2 & \multirow{6}{*}{$0,133^{* * * *}$} \\
\hline 30-39 éves & 336 & 73,5 & & 6,2 & \\
\hline 40-49 éves & 372 & 69,4 & & 9,4 & \\
\hline 50-59 éves & 326 & 69,3 & & 6,1 & \\
\hline 60-69 éves & 275 & 63,6 & & 10,5 & \\
\hline 70 éves és idősebb & 258 & 50,4 & & 18,9 & \\
\hline Nagyváros és elővárosa & 576 & 64,8 & & & \\
\hline Város vagy kisváros & 707 & 66,8 & & & \\
\hline Falu/község/tanya & 688 & 66,1 & & & \\
\hline Alapfokú vagy kevesebb & 458 & 50,4 & \multirow{4}{*}{$0,215 * * *$} & 17,9 & \multirow{4}{*}{$0,166 * * *$} \\
\hline Szakmunkás & 521 & 65,3 & & 9,0 & \\
\hline Érettségi & 626 & 69,2 & & 7,2 & \\
\hline Felsőfokú & 362 & 81,5 & & 3,9 & \\
\hline Házas vagy élettárssal él & 859 & 69,0 & \multirow{2}{*}{$0,061^{* *}$} & 6,5 & \multirow{2}{*}{$0,098 * * *$} \\
\hline Egyedülálló & 1068 & 63,2 & & 12,4 & \\
\hline Dolgozik & 909 & 75,2 & \multirow{2}{*}{$0,182 * * *$} & 5,1 & \multirow{2}{*}{$0,142 * * *$} \\
\hline Nem dolgozik & 1044 & 58,0 & & 13,4 & \\
\hline $\begin{array}{c}\text { Egy före jutó havi nettó } \\
\text { háztartási jövedelem: } \\
\text { átlag felett } \\
\text { átlag alatt }\end{array}$ & $\begin{array}{l}621 \\
777\end{array}$ & $\begin{array}{l}65,1 \\
64,7\end{array}$ & & $\begin{array}{l}10,1 \\
10,7\end{array}$ & \\
\hline $\begin{array}{l}\text { Elidegenedés skála: } \\
\text { átlag alatt }\end{array}$ & 978 & 83,1 & \multirow{2}{*}{$0,363 * * *$} & 2,6 & \multirow{2}{*}{$0,236^{* * *}$} \\
\hline átlag felett & 956 & 48,7 & & 16,3 & \\
\hline $\begin{array}{c}\text { Személyes beállítottság: } \\
\text { optimista }\end{array}$ & 1049 & 81,6 & \multirow{2}{*}{$0,345^{* * *}$} & 4,0 & \multirow{2}{*}{$0,201 * * *$} \\
\hline pesszimista & 889 & 48,0 & & 15,8 & \\
\hline $\begin{array}{l}\text { Szubj. egészségi állapot: rossz } \\
\text { és nagyon rossz }\end{array}$ & 263 & 43,0 & \multirow{3}{*}{$0,203 * * *$} & 27,4 & \multirow{3}{*}{$0,240 * * *$} \\
\hline kielégítő & 544 & 64,0 & & 8,3 & \\
\hline Jó és nagyon jó & 1164 & 72,0 & & 6,1 & \\
\hline Nincs biztonságérzete & 539 & 62,7 & \multirow{2}{*}{$0,046^{*}$} & 13,9 & \multirow{2}{*}{$0,093^{* * *} *$} \\
\hline Van biztonságérzete & 1395 & 67,5 & & 7,8 & \\
\hline $\begin{array}{c}\text { Szubj. jövedelmi helyzet: } \\
\text { nagyon nehezen élünk meg }\end{array}$ & 418 & 45,7 & \multirow{4}{*}{$0,244 * * *$} & 19,4 & \multirow{4}{*}{$0,199^{* * * *}$} \\
\hline ...nehezen élünk meg & 677 & 66,3 & & 10,5 & \\
\hline ...kijövünk & 728 & 75,5 & & 4,5 & \\
\hline ...kényelmesen megélünk & 123 & 78,9 & & 1,6 & \\
\hline
\end{tabular}

$*=0,05 ; * *=0,01 ; * * *=0,001$ szinten szignifikáns. 


\section{F.9.4. A boldogság és a szocio-demográfiai jellemzők közötti összefüggések - arányok összehasonlítása}

F.9.4.a. táblázat: A boldogok és a boldogtalanok aránya az egyes társadalmidemográfiai és szubjektív változókategóriák szerint, 2006

\begin{tabular}{|c|c|c|c|c|c|}
\hline & & \multicolumn{2}{|c|}{ Boldogok } & \multicolumn{2}{|c|}{ Boldogtalanok } \\
\hline & $\mathrm{N}$ & Valid\% & Phi/ Cramer's V & Valid\% & Phi/ Cramer's V \\
\hline Minta & 1508 & 63,9 & & 17,1 & \\
\hline Férfi & 643 & 65,2 & & 16,7 & \\
\hline Nő & 865 & 62,9 & & 17,4 & \\
\hline 30 év alatt & 378 & 78,8 & \multirow{6}{*}{$0,202 * * *$} & 9,8 & \multirow{6}{*}{$0,124 * * *$} \\
\hline 30-39 éves & 225 & 61,3 & & 16,5 & \\
\hline 40-49 éves & 305 & 64,6 & & 17,7 & \\
\hline 50-59 éves & 240 & 50,0 & & 21,8 & \\
\hline 60-69 éves & 205 & 57,6 & & 19,5 & \\
\hline 70 éves vagy idősebb & 149 & 61,1 & & 23,3 & \\
\hline Nagyváros és elővárosa & 364 & 69,2 & \multirow{3}{*}{$0,066^{*}$} & 14,6 & \\
\hline Város vagy kisváros & 562 & 63,2 & & 17,6 & \\
\hline Falu/község/tanya & 582 & 61,2 & & 18,2 & \\
\hline Alapfokú vagy kevesebb & 513 & 58,5 & \multirow{4}{*}{$0,172 * * *$} & 20,9 & \multirow{4}{*}{$0,109 * * *$} \\
\hline Szakmunkás & 386 & 56,0 & & 19,7 & \\
\hline Érettségi & 382 & 70,2 & & 13,1 & \\
\hline Felsőfokú & 224 & 78,6 & & 10,7 & \\
\hline Házas vagy élettárssal él & 896 & 67,0 & \multirow{2}{*}{$0,078 * *$} & 12,9 & \multirow{2}{*}{$0,134 * * *$} \\
\hline Egyedülálló & 607 & 59,3 & & 23,2 & \\
\hline Dolgozik & 740 & 66,8 & \multirow{2}{*}{$0,096^{* * * *}$} & 14,5 & \multirow{2}{*}{$0,088 * * *$} \\
\hline Nem dolgozik & 632 & 57,4 & & 21,2 & \\
\hline $\begin{array}{c}\text { Egy före jutó havi nettó } \\
\text { háztartási jövedelem: } \\
\text { átlag felett }\end{array}$ & 570 & 69,1 & \multirow[t]{2}{*}{$0,119 * * *$} & 12,3 & \multirow[t]{2}{*}{$0,133 * * *$} \\
\hline átlag alatt & 675 & 57,6 & & 22,5 & \\
\hline $\begin{array}{l}\text { Elidegenedés skála: } \\
\text { átlag alatt }\end{array}$ & 821 & 78,2 & \multirow[t]{2}{*}{$0,333 * * *$} & 6,3 & \multirow[t]{2}{*}{$0,322 * * *$} \\
\hline átlag felett & 629 & 45,9 & & 30,7 & \\
\hline $\begin{array}{l}\text { Személyes beállítottság: } \\
\text { optimista }\end{array}$ & 803 & 79,2 & \multirow{2}{*}{$0,340 * * *$} & 6,6 & \multirow{2}{*}{$0,300 * * *$} \\
\hline pesszimista & 678 & 46,5 & & 29,2 & \\
\hline $\begin{array}{l}\text { Szubj. egészségi állapot: rossz } \\
\text { és nagyon rossz }\end{array}$ & 238 & 37,4 & \multirow{3}{*}{$0,315^{* * *}$} & 45,0 & \multirow{3}{*}{$0,337 * * *$} \\
\hline kielégítő & 546 & 56,4 & & 16,8 & \\
\hline Jó és nagyon jó & 723 & 78,1 & & 8,2 & \\
\hline Nincs biztonságérzete & 347 & 48,7 & \multirow{2}{*}{$0,175^{* * *}$} & 26,0 & \multirow{2}{*}{$0,131 * * *$} \\
\hline Van biztonságérzete & 1145 & 68,6 & & 14,3 & \\
\hline $\begin{array}{c}\text { Szubj. jövedelmi helyzet: } \\
\text { nagyon nehezen élünk meg }\end{array}$ & 179 & 34,6 & \multirow{4}{*}{$0,308 * * *$} & 41,3 & \multirow{4}{*}{$0,314 * * *$} \\
\hline ...nehezen élünk meg & 486 & 53,9 & & 24,7 & \\
\hline ...kijövünk & 747 & 74,8 & & 7,6 & \\
\hline ...kényelmesen megélünk & 86 & 84,9 & & 7,0 & \\
\hline
\end{tabular}

$*=0,05 ; * *=0,01 ; * * *=0,001$ szinten szignifikáns. 
F.9.4.b. táblázat: A boldogok és a boldogtalanok aránya az egyes társadalmidemográfiai és szubjektív változókategóriák szerint, 2012

\begin{tabular}{|c|c|c|c|c|c|}
\hline & & \multicolumn{2}{|c|}{ Boldogok } & \multicolumn{2}{|c|}{ Boldogtalanok } \\
\hline & $\mathrm{N}$ & Valid\% & Phi/ Cramer's V & Valid\% & Phi/ Cramer's V \\
\hline Minta & 2007 & 61,5 & & 21,4 & \\
\hline Férfi & 899 & 61,1 & & 22,8 & \\
\hline Nő & 1108 & 61,9 & & 20,2 & \\
\hline 30 év alatt & 410 & 72,0 & \multirow{6}{*}{$0,167 * * *$} & 12,5 & \multirow{6}{*}{$0,150 * * *$} \\
\hline 30-39 éves & 339 & 70,2 & & 16,5 & \\
\hline 40-49 éves & 375 & 61,1 & & 22,7 & \\
\hline 50-59 éves & 332 & 56,0 & & 24,1 & \\
\hline 60-69 éves & 281 & 54,4 & & 25,3 & \\
\hline 70 éves és idősebb & 270 & 49,6 & & 31,5 & \\
\hline Nagyváros és elővárosa & 581 & 63,2 & & 21,2 & \\
\hline Város vagy kisváros & 724 & 61,3 & & 20,6 & \\
\hline Falu/község/tanya & 700 & 60,4 & & 22,1 & \\
\hline Alapfokú vagy kevesebb & 473 & 50,1 & \multirow{4}{*}{$0,196 * * *$} & 32,4 & \multirow{4}{*}{$0,175^{* * *}$} \\
\hline Szakmunkás & 532 & 54,7 & & 23,1 & \\
\hline Érettségi & 635 & 67,9 & & 17,2 & \\
\hline Felsőfokú & 362 & 75,4 & & 11,8 & \\
\hline Házas vagy élettárssal él & 873 & 65,5 & \multirow{2}{*}{$0,074 * * *$} & 17,8 & \multirow{2}{*}{$0,082 * * *$} \\
\hline Egyedülálló & 1084 & 58,3 & & 24,5 & \\
\hline Dolgozik & 914 & 68,9 & \multirow{2}{*}{$0,142 * * *$} & 14,7 & \multirow{2}{*}{$0,152 * * *$} \\
\hline Nem dolgozik & 1073 & 55,1 & & 27,2 & \\
\hline $\begin{array}{l}\text { Egy före jutó havi nettó } \\
\text { háztartási jövedelem: } \\
\text { átlag felett }\end{array}$ & 630 & 60,5 & & 21,4 & \\
\hline átlag alatt & 790 & 59,6 & & 24,2 & \\
\hline $\begin{array}{l}\text { Elidegenedés skála: } \\
\text { átlag alatt }\end{array}$ & 990 & 77,6 & \multirow[t]{2}{*}{$0,327 * * *$} & 9,0 & \multirow[t]{2}{*}{$0,301 * * *$} \\
\hline átlag felett & 970 & 45,8 & & 33,6 & \\
\hline $\begin{array}{l}\text { Személyes beállítottság: } \\
\text { optimista }\end{array}$ & 1059 & 78,6 & \multirow{2}{*}{$0,370 * * *$} & 9,3 & \multirow{2}{*}{$0,312 * * *$} \\
\hline pesszimista & 910 & 42,5 & & 34,8 & \\
\hline $\begin{array}{c}\text { Szubj. egészségi állapot: rossz és } \\
\text { nagyon rossz }\end{array}$ & 275 & 32,7 & \multirow{3}{*}{$0,305 * * *$} & 47,6 & \multirow{3}{*}{$0,296 * * *$} \\
\hline kielégítő & 556 & 51,3 & & 26,8 & \\
\hline Jó és nagyon jó & 1176 & 73,0 & & 12,7 & \\
\hline Nincs biztonságérzete & 556 & 53,1 & \multirow{2}{*}{$0,111 * * *$} & 27,2 & \multirow{2}{*}{$0,091 * * *$} \\
\hline Van biztonságérzete & 1412 & 65,0 & & 18,9 & \\
\hline $\begin{array}{l}\text { Szubj. jövedelmi helyzet: } \\
\text { nagyon nehezen élünk meg }\end{array}$ & 430 & 37,2 & \multirow{4}{*}{$0,328 * * *$} & 42,6 & \multirow{4}{*}{$0,319 * * *$} \\
\hline ...nehezen élünk meg & 688 & 57,8 & & 23,8 & \\
\hline ...kijövünk & 739 & 74,8 & & 9,5 & \\
\hline ...kényelmesen megélünk & 123 & 91,1 & & 4,1 & \\
\hline
\end{tabular}

$*=0,05 ; * *=0,01 ; * * *=0,001$ szinten szignifikáns. 


\section{F.9.5. A Pozitív-Negatív Érzelmi Balansz és a szocio-demográfiai jellemzők kapcsolata - arányok összehasonlítása}

F.9.5.a. táblázat: A pozitív érzelmi mérleget és a negatív mérleget mutatók aránya az egyes társadalmi-demográfiai és szubjektív változókategóriák szerint, 2006

\begin{tabular}{|c|c|c|c|c|}
\hline & & Pozitív balansz & Negatív balansz & \\
\hline & $\mathrm{N}$ & Valid $\%$ & Valid\% & Phi/ Cramer's V \\
\hline Minta & 1476 & 53,2 & 46,8 & \\
\hline Férfi & 631 & 56,3 & 43,7 & \multirow{2}{*}{$0,053 *$} \\
\hline Nő & 844 & 50,9 & 49,1 & \\
\hline 30 év alatt & 369 & 67,2 & 32,8 & \multirow{6}{*}{$0,172 * * *$} \\
\hline 30-39 éves & 221 & 52,5 & 47,5 & \\
\hline 40-49 éves & 298 & 49,0 & 51,0 & \\
\hline $50-59$ éves & 237 & 50,2 & 49,8 & \\
\hline 60-69 éves & 202 & 48,0 & 52,0 & \\
\hline 70 éves és idősebb & 141 & 40,4 & 59,6 & \\
\hline Nagyváros és elővárosa & 359 & 57,1 & 42,9 & \multirow{3}{*}{$0,069 *$} \\
\hline Város vagy kisváros & 552 & 55,1 & 44,9 & \\
\hline Falu/község/tanya & 564 & 48,9 & 51,1 & \\
\hline Alapfokú vagy kevesebb & 505 & 45,1 & 54,9 & \multirow{4}{*}{$0,149 * * *$} \\
\hline Szakmunkás & 376 & 50,3 & 49,7 & \\
\hline Érettségi & 372 & 60,5 & 39,5 & \\
\hline Felsőfokú & 220 & 64,1 & 35,9 & \\
\hline Házas vagy élettárssal él & 882 & 55,7 & 44,3 & \multirow{2}{*}{$0,060 *$} \\
\hline Egyedülálló & 591 & 49,6 & 50,4 & \\
\hline Dolgozik & 729 & 56,5 & 43,5 & \multirow{2}{*}{$0,086^{* *}$} \\
\hline Nem dolgozik & 616 & 47,9 & 52,1 & \\
\hline $\begin{array}{c}\text { Egy före jutó havi nettó } \\
\text { háztartási jövedelem: } \\
\text { átlag felett }\end{array}$ & 555 & 57,8 & 42,2 & \multirow[t]{2}{*}{$0,099 * * *$} \\
\hline átlag alatt & 661 & 48,0 & 52,0 & \\
\hline $\begin{array}{l}\text { Elidegenedés skála: } \\
\text { átlag alatt }\end{array}$ & 804 & 70,0 & 30,0 & \multirow[t]{2}{*}{$0,373 * * *$} \\
\hline átlag felett & 621 & 32,5 & 67,5 & \\
\hline $\begin{array}{c}\text { Személyes beállítottság: } \\
\text { optimista }\end{array}$ & 785 & 70,7 & 29,3 & \multirow[t]{2}{*}{$0,371 * * *$} \\
\hline pesszimista & 668 & 33,5 & 66,5 & \\
\hline $\begin{array}{c}\text { Szubj. egészségi állapot: rossz } \\
\text { és nagyon rossz }\end{array}$ & 235 & 26,4 & 73,6 & \multirow{3}{*}{$0,326^{* * * *}$} \\
\hline kielégítő & 533 & 44,1 & 55,9 & \\
\hline Jó és nagyon jó & 706 & 69,0 & 31,0 & \\
\hline Nincs biztonságérzete & 337 & 38,3 & 61,7 & \multirow{2}{*}{$0,164 * * *$} \\
\hline Van biztonságérzete & 1122 & 57,7 & 42,3 & \\
\hline $\begin{array}{c}\text { Szubj. jövedelmi helyzet: } \\
\text { nagyon nehezen élünk meg }\end{array}$ & 177 & 32,2 & 67,8 & \multirow{4}{*}{$0,224 * * *$} \\
\hline ...nehezen élünk meg & 476 & 44,7 & 55,3 & \\
\hline ...kijövünk & 725 & 62,3 & 37,7 & \\
\hline ...kényelmesen megélünk & 87 & 64,4 & 35,6 & \\
\hline
\end{tabular}


F.9.5.b. táblázat: A pozitív érzelmi mérleget és a negatív mérleget mutatók aránya az egyes társadalmi-demográfiai és szubjektív változókategóriák szerint, 2012

\begin{tabular}{|c|c|c|c|c|}
\hline & & Pozitív balansz & Negatív balansz & \\
\hline & $\mathrm{N}$ & Valid\% & Valid\% & Phi/ Cramer's V \\
\hline Minta & 1963 & 52,9 & 47,1 & \\
\hline Férfi & 881 & 55,5 & 44,5 & \multirow{2}{*}{$0,047 *$} \\
\hline Nő & 1082 & 50,7 & 49,3 & \\
\hline 30 év alatt & 400 & 64,8 & 35,3 & \multirow{6}{*}{$0,172 * * *$} \\
\hline 30-39 éves & 333 & 58,0 & 42,0 & \\
\hline 40-49 éves & 372 & 54,6 & 45,4 & \\
\hline $50-59$ éves & 323 & 47,4 & 52,6 & \\
\hline 60-69 éves & 275 & 48,4 & 51,6 & \\
\hline 70 éves és idősebb & 260 & 37,3 & 62,7 & \\
\hline Nagyváros és elővárosa & 575 & 59,8 & 40,2 & \multirow{3}{*}{$0,089 * * *$} \\
\hline Város vagy kisváros & 706 & 49,9 & 50,1 & \\
\hline Falu/község/tanya & 680 & 50,3 & 49,7 & \\
\hline Alapfokú vagy kevesebb & 459 & 37,3 & 62,7 & \multirow{4}{*}{$0,221 * * *$} \\
\hline Szakmunkás & 520 & 48,5 & 51,5 & \\
\hline Érettségi & 625 & 58,4 & 41,6 & \\
\hline Felsőfokú & 353 & 69,4 & 30,6 & \\
\hline Házas vagy élettárssal él & 850 & 56,4 & 43,6 & \multirow{2}{*}{$0,066^{* *}$} \\
\hline Egyedülálló & 1066 & 49,7 & 50,3 & \\
\hline Dolgozik & 901 & 59,8 & 40,2 & \multirow{2}{*}{$0,126^{* * * *}$} \\
\hline Nem dolgozik & 1045 & 47,2 & 52,8 & \\
\hline $\begin{array}{c}\text { Egy före jutó havi nettó háztart } \\
\text { jövedelem: } \\
\text { átlag felett }\end{array}$ & 617 & 52,8 & 47,2 & \multirow[t]{2}{*}{$0,060^{*}$} \\
\hline átlag alatt & 772 & 46,8 & 53,2 & \\
\hline $\begin{array}{c}\text { Elidegenedés skála: } \\
\text { átlag alatt }\end{array}$ & 972 & 73,8 & 26,2 & \multirow[t]{2}{*}{$0,423 * * *$} \\
\hline átlag felett & 955 & 32,6 & 67,4 & \\
\hline $\begin{array}{c}\text { Személyes beállítottság: } \\
\text { optimista }\end{array}$ & 1043 & 73,8 & 26,2 & \multirow{2}{*}{$0,445^{* * * *}$} \\
\hline pesszimista & 886 & 29,2 & 70,8 & \\
\hline $\begin{array}{l}\text { Szubj. egészségi állapot: } \\
\text { rossz és nagyon rossz }\end{array}$ & 266 & 17,7 & 82,3 & \multirow{3}{*}{$0,344 * * *$} \\
\hline kielégítő & 539 & 42,5 & 57,5 & \\
\hline jó és nagyon jó & 1156 & 65,7 & 34,3 & \\
\hline Nincs biztonságérzete & 542 & 44,1 & 55,9 & \multirow{2}{*}{$0,113 * * *$} \\
\hline Van biztonságérzete & 1384 & 56,6 & 43,4 & \\
\hline $\begin{array}{l}\text { Szubj. jövedelmi helyzet: } \\
\text { nagyon nehezen élünk meg }\end{array}$ & 418 & 29,4 & 70,6 & \multirow{4}{*}{$0,331 * * *$} \\
\hline ...nehezen élünk meg & 674 & 46,4 & 53,6 & \\
\hline ...kijövünk & 730 & 66,2 & 33,8 & \\
\hline ...kényelmesen megélünk & 120 & 87,5 & 12,5 & \\
\hline
\end{tabular}

$*=0,05 ; * *=0,01 ; * * *=0,001$ szinten szignifikáns. 


\section{F.10. A szubjektív életminőség társadalmi-demográfiai jellemzői ${ }^{21}$}

F.10.1.a. ábra: A Szubjektív Életminőség Index és a családi állapot összefüggése, 2006 (Z-score átlag) $(\mathrm{N}=1429)$

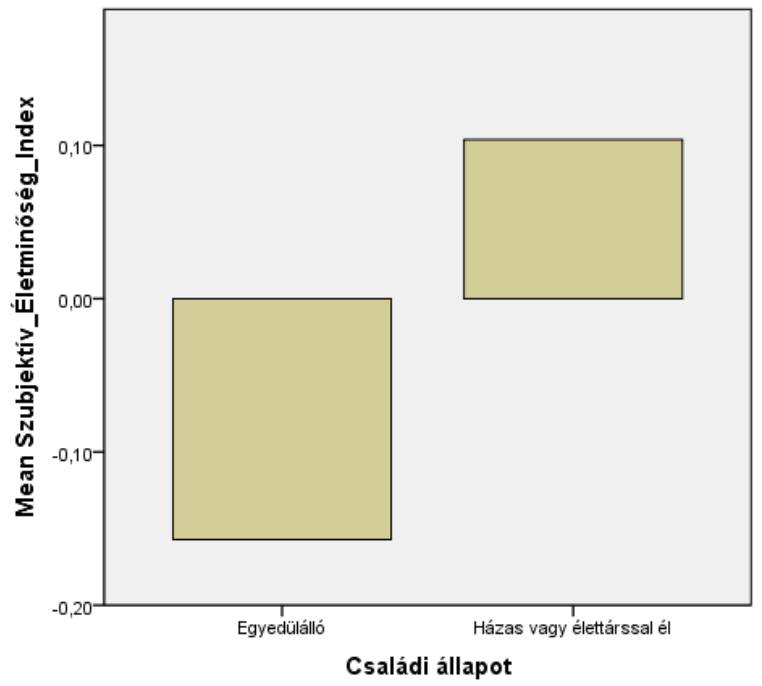

F.10.1.b. ábra: A Szubjektív Életminőség Index és a családi állapot összefüggése, 2012 (Z-score átlag) $(\mathrm{N}=1863)$

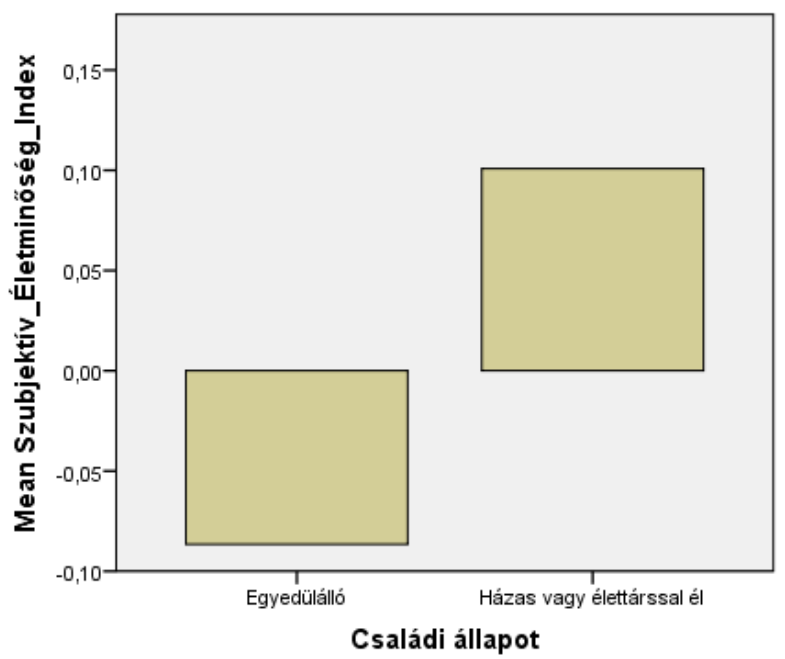

21 A társadalmi-demográfiai tényezők és a szubjektív életminőség kapcsolatát a kontroll- és a magyarázó változók dichotóm indikátoraira, illetve az egy före jutó havi nettó háztartási jövedelem és az anómia és elidegenedés skála mutatóira vonatkozóan prezentáljuk. A hiányzó (missing) esetek kezelése: listwise. 
F.10.2.a. ábra: A Szubjektív Életminőség Index és az egy före jutó havi nettó háztartási jövedelem összefüggése, 2006 (Curve estimation)*

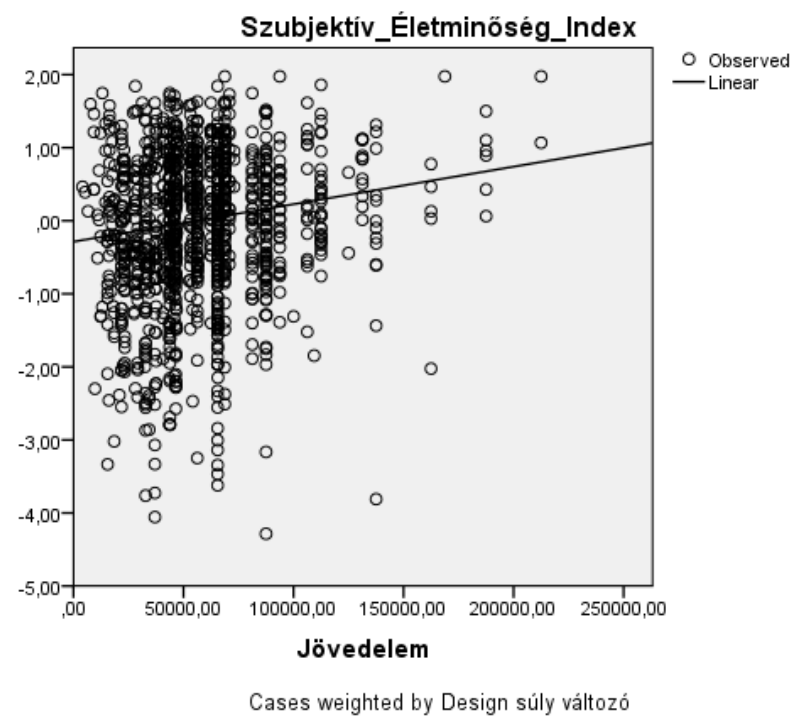

*Statisztika: $\mathrm{N}=1189, \mathrm{R}^{2}=0,019 ; \mathrm{F}=22,877, \mathrm{df}=1, \mathrm{df} 2=1181,00 ;$ Sign.=,000.

F.10.2.b. ábra: A Szubjektív Életminőség Index és az egy főre jutó havi nettó háztartási jövedelem összefüggése, 2012 (Curve estimation)*

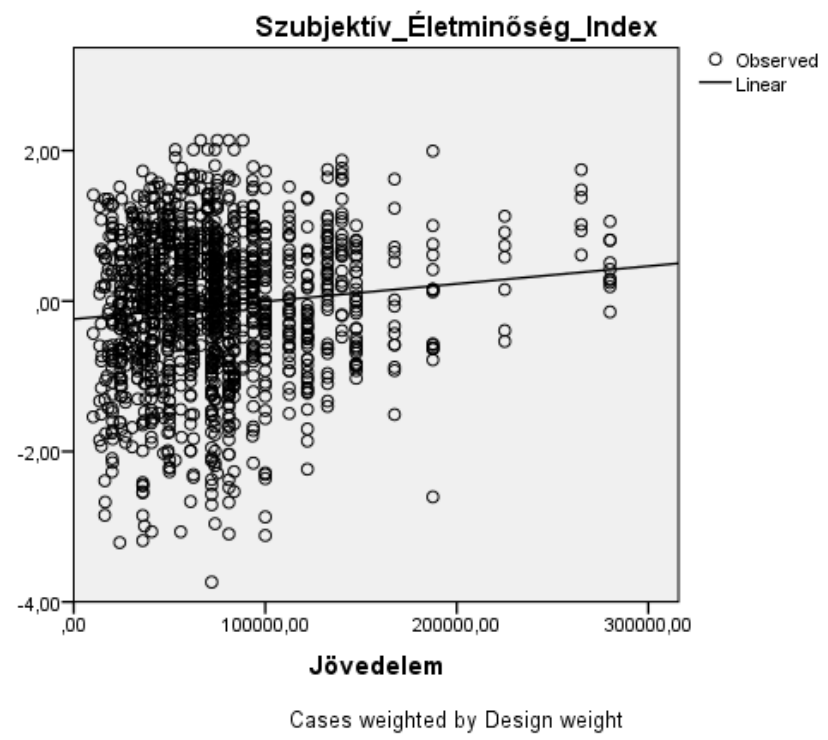

*Statisztika: $\mathrm{N}=1357, \mathrm{R}^{2}=0,011 ; \mathrm{F}=15,084, \mathrm{df}=1, \mathrm{df2}=1355,95 ;$ Sign.=,000. 
F.10.3.a. ábra: A Szubjektív Életminőség Index és az Elidegenedés Skála összefüggése, 2006 (Curve estimation)*

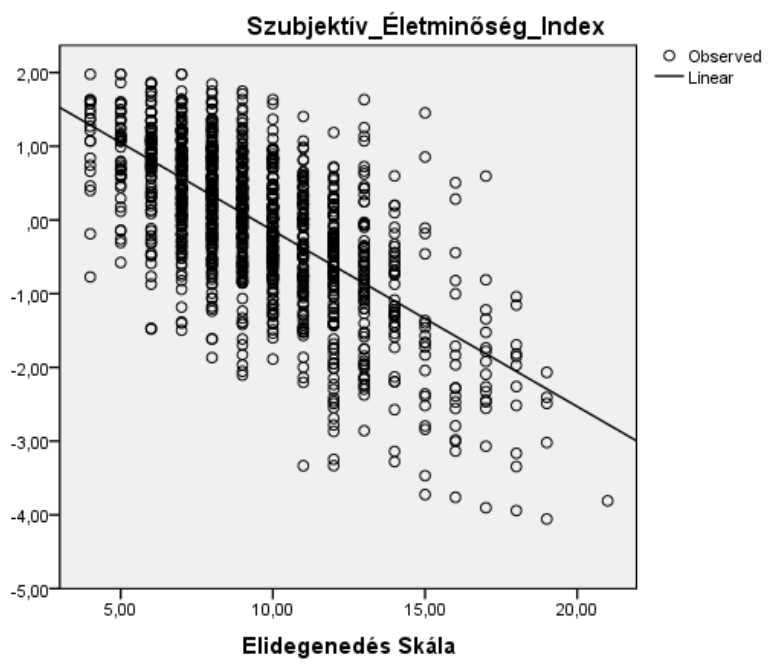

Cases weighted by Design súly változó

*Modell statisztika: N=1375, $\mathrm{R}^{2}=0,426 ; \mathrm{F}=1033,896, \mathrm{df}=1$, df2=1391,86; Sign.=,000.

F.10.3.b. ábra: A Szubjektív Életminőség Index és az Elidegenedés Skála összefüggése, 2012 (Curve estimation)*

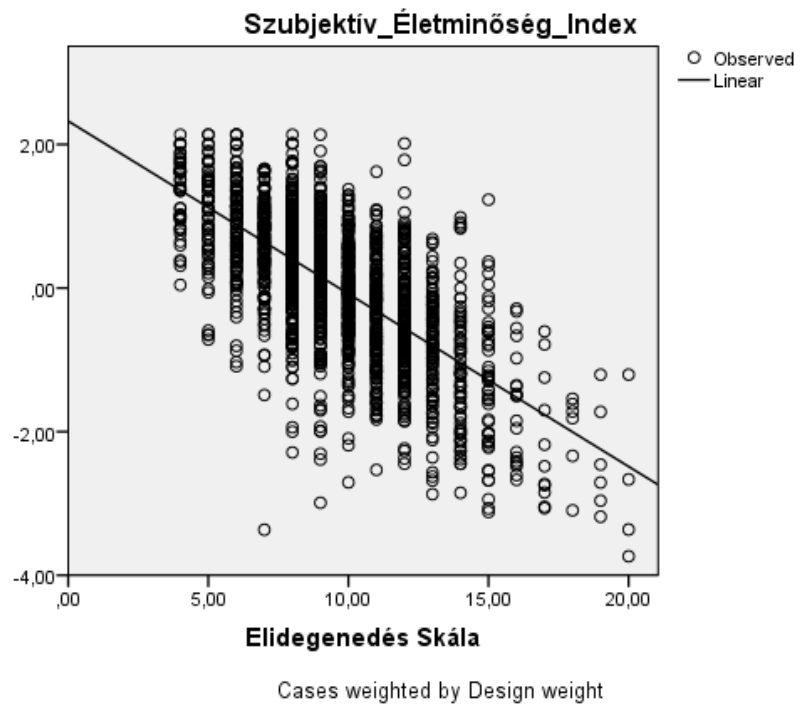

*Modell statisztika: N=1876, $\mathrm{R}^{2}=0,459 ; \mathrm{F}=1587,397, \mathrm{df}=1$, df2=1874,29; Sign.=,000. 
F.10.4.a. ábra: A Szubjektív Életminőség Index és a dichotóm szubjektív egészségi állapot változó* kapcsolata, 2006 (Z-score átlag) $(\mathrm{N}=1432)$

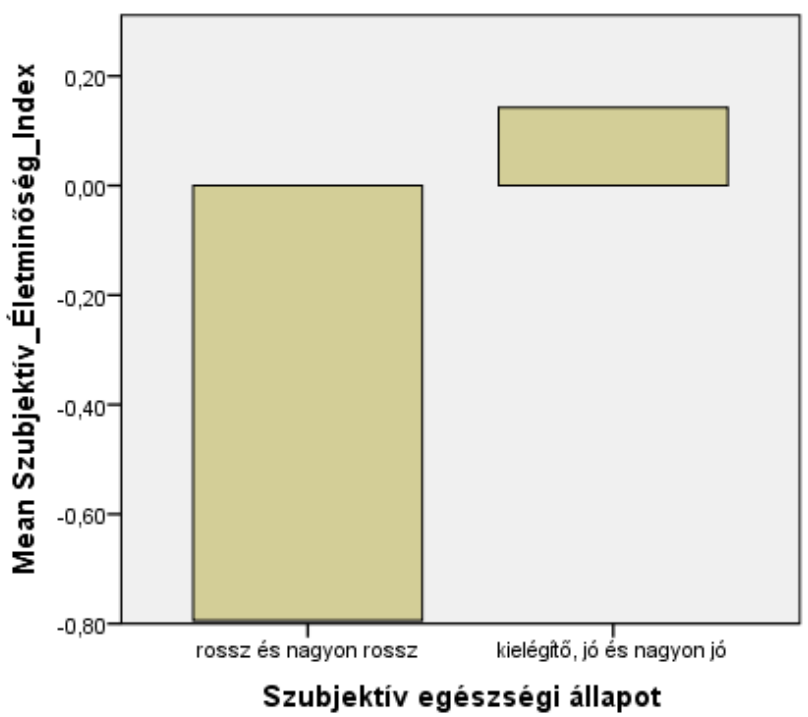

* A dichotóm változó kategóriái: $0=$ rossz egészségi állapot; $1=$ jó egészségi állapot.

F.10.4.b. ábra: A Szubjektív Életminőség Index és a dichotóm szubjektív egészségi állapot változó* kapcsolata, 2012 (Z-score átlag) (N=1905)

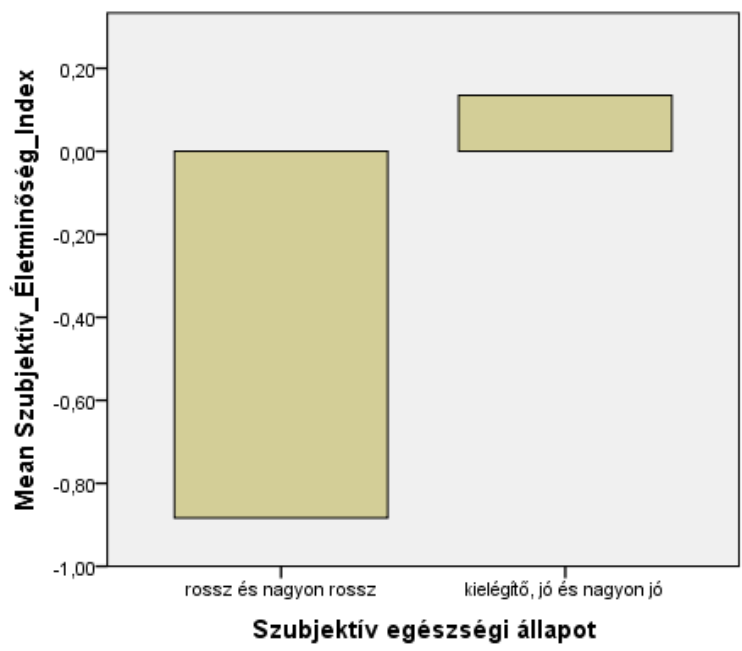

* A dichotóm változó kategóriái: 0=rossz egészségi állapot; $1=$ jó egészségi állapot. 
F.10.5.a. ábra: A Szubjektív Életminőség Index és a biztonságérzet kapcsolata, 2006 (Z-score átlag) $(\mathrm{N}=1419)$

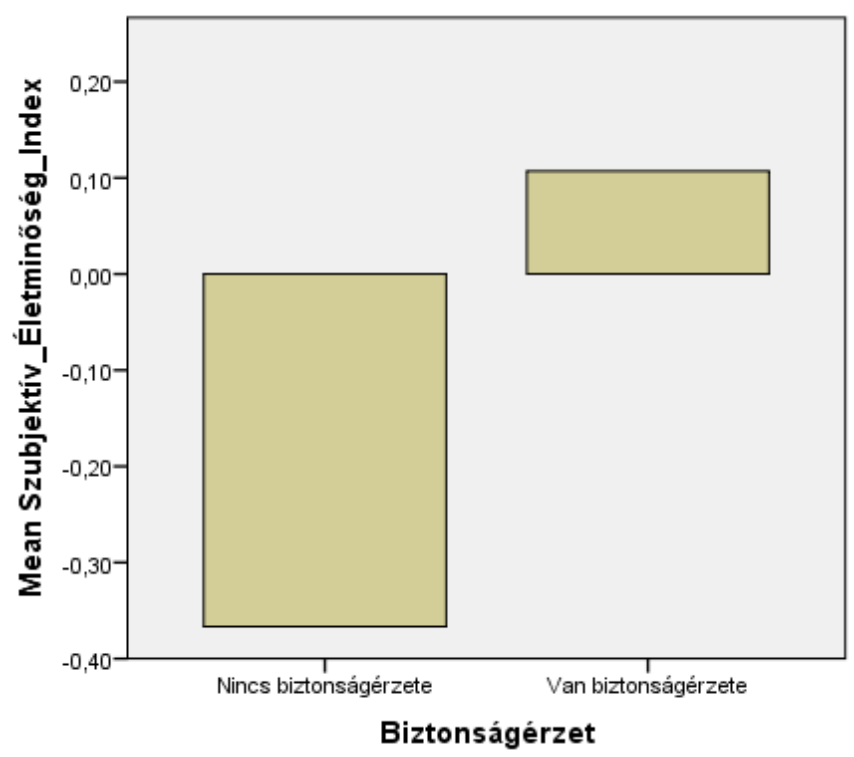

F.10.5.b. ábra: A Szubjektív Életminőség Index és a biztonságérzet kapcsolata, 2012 (Z-score átlag) $(\mathrm{N}=1871)$

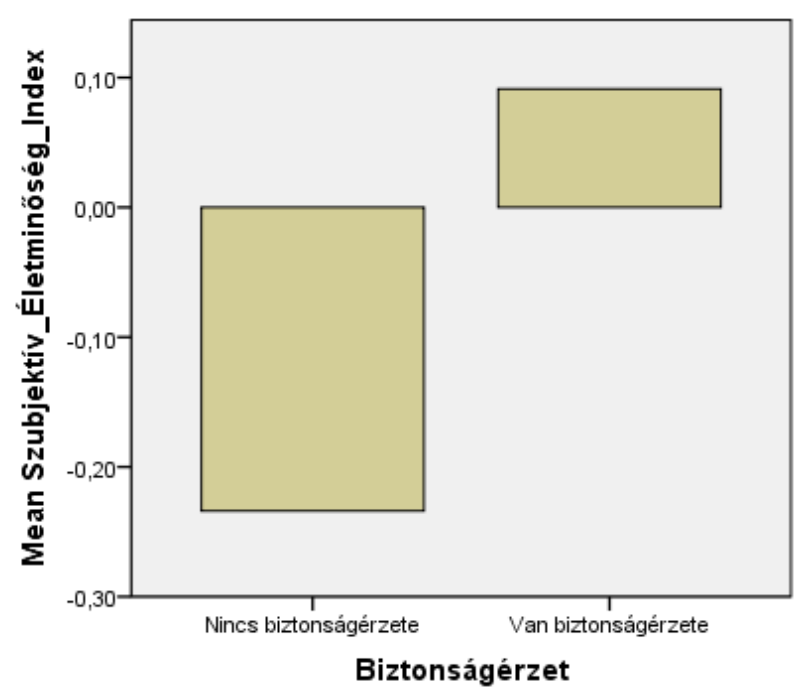


F.10.6.a. ábra: A Szubjektív Életminőség Index és a szubjektív jövedelmi helyzet változó* kapcsolata, 2006 (Z-score átlag) $(\mathrm{N}=1424)$

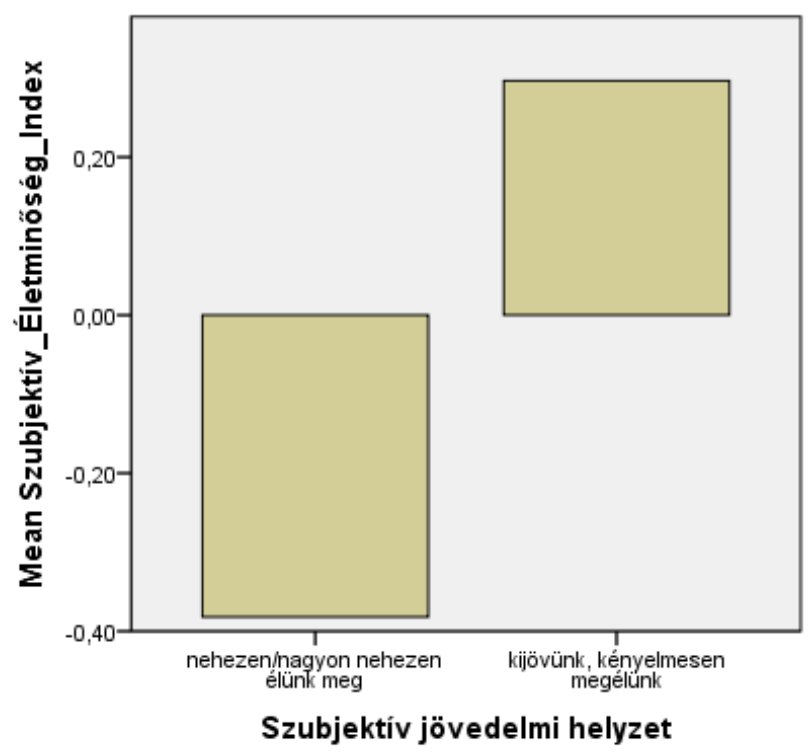

*A dichotóm változó kategóriái: $0=$ nem jönnek ki havi bevételeikből, $1=$ kijönnek havi bevételeikből

F.10.6.b. ábra: A Szubjektív Életminőség Index és a szubjektív jövedelmi helyzet változó* kapcsolata, 2012 (Z-score átlag) $(\mathrm{N}=1887)$

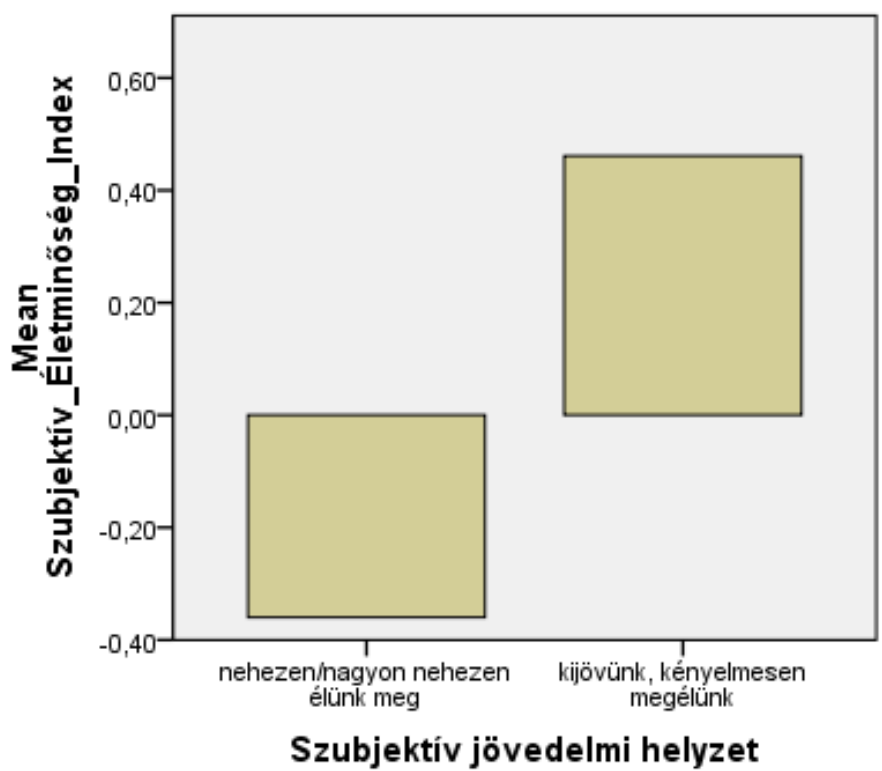

*A dichotóm változó kategóriái: $0=$ nem jönnek ki havi bevételeikből, $1=$ kijönnek havi bevételeikből 


\section{F.11. Függelék: A kontroll- és magyarázó változók megoszlása az összevont mintában}

F.11. táblázat: A kontrollváltozók, illetve a dichotóm magyarázó változók megoszlásai az összevont keresztmetszeti mintában (\%), súlyozatlan adatok

\begin{tabular}{|l|c|c|}
\hline & Valid\% & N \\
\hline Férfi & 43,3 & 3532 \\
\hline Életkor: 30 évtől fiatalabb & 20,8 & 3517 \\
\hline $30-39$ éves & 15,8 & 3517 \\
\hline $40-49$ éves & 17,8 & 3517 \\
\hline 50-59 éves & 16,6 & 3517 \\
\hline 60-69 éves & 15,3 & 3517 \\
\hline 70 éves és idősebb & 13,8 & 3517 \\
\hline Nagyváros & 28,1 & 3528 \\
\hline Város & 36,8 & 3528 \\
\hline Falu-község-tanya & 35,1 & 3528 \\
\hline Alapfokú vagy alacsonyabb iskolai & 28,9 & 3520 \\
\hline végzettség & 25,8 & 3520 \\
\hline Szakmunkás & 28,4 & 3520 \\
\hline Érettségi & 17,0 & 3520 \\
\hline Felsőfokú & 47,6 & 3472 \\
\hline Házas/élettárssal él & 47,2 & 3402 \\
\hline Dolgozik & 84,3 & 3530 \\
\hline Jó szubjektív egészség & 48,2 & 3490 \\
\hline Kijönnek a bevételeikből & 73,5 & 3466 \\
\hline Van biztonságérzete & 50,0 & 3510 \\
\hline Optimista & & \\
\hline
\end{tabular}




\section{F.12. Függelék: A dichotóm változók leíró statisztikái az összevont mintában}

F.12. táblázat: A dichotóm kontroll- és magyarázó változók leíró statisztikái az összevont keresztmetszeti mintában

\begin{tabular}{|c|c|c|c|c|c|}
\hline & $\mathbf{N}$ & Minimum & Maximum & Mean & Std. Deviation \\
\hline Férfi & 3532 & 0,00 & 1,00 & 0,4394 & 0,49638 \\
\hline Életkor: 30 évtől fiatalabb & 3525 & 0,00 & 1,00 & 0,2241 & 0,41705 \\
\hline 30-39 éves & 3525 & 0,00 & 1,00 & 0,1606 & 0,36722 \\
\hline 40-49 éves & 3525 & 0,00 & 1,00 & 0,1938 & 0,39534 \\
\hline 50-59 éves & 3525 & 0,00 & 1,00 & 0,1629 & 0,36931 \\
\hline 60-69 éves & 3516 & 0,00 & 1,00 & 0,1542 & 0,36122 \\
\hline 70 éves és idősebb & 3516 & 0,00 & 1,00 & 0,1401 & 0,34710 \\
\hline Nagyváros & 3529 & 0,00 & 1,00 & 0,2689 & 0,44347 \\
\hline Város & 3529 & 0,00 & 1,00 & 0,3652 & 0,48154 \\
\hline Falu-község-tanya & 3529 & 0,00 & 1,00 & 0,3659 & 0,48175 \\
\hline Alapfokú vagy kevesebb & 3523 & 0,00 & 1,00 & 0,2818 & 0,44993 \\
\hline Szakmunkás & 3523 & 0,00 & 1,00 & 0,2618 & 0,43967 \\
\hline Érettségi & 3523 & 0,00 & 1,00 & 0,2894 & 0,45355 \\
\hline Felsőfokú & 3523 & 0,00 & 1,00 & 0,1670 & 0,37305 \\
\hline Házas/élettárssal él & 3468 & 0,00 & 1,00 & 0,4701 & 0,49918 \\
\hline Dolgozik & 3408 & 0,00 & 1,00 & 0,4737 & 0,49938 \\
\hline Kijönnek a bevételeikböl & 3494 & 0,00 & 1,00 & 0,4870 & 0,49990 \\
\hline Jó szubjektív egészség & 3530 & 0,00 & 1,00 & 0,8533 & 0,35382 \\
\hline Van biztonságérzete & 3473 & 0,00 & 1,00 & 0,7391 & 0,43920 \\
\hline $\begin{array}{l}\text { Anómia- és elidegenedés } \\
\text { Skála }\end{array}$ & 3423 & $-1,91$ & 3,93 & 0,0000 & 0,95851 \\
\hline Optimista & 3510 & 0,00 & 1,00 & 0,5107 & 0,49996 \\
\hline Valid N (listwise) & 3131 & & & & \\
\hline
\end{tabular}




\section{F.13. Függelék: A társadalmi integráció és a szubjektív indikátorok hipotéziseinek a szubjektív életminőség mértékével kapcsolatban felépített regressziós modelljei}

F.13. táblázat: A társadalmi integráció, a szubjektív jövedelmi helyzet, a szubjektív egészség és a biztonságérzet hipotéziseinek a szubjektív életminőség mértékével kapcsolatban felépített regressziós modelljei, összevont keresztmetszeti adatok, OLS (sztenderdizálatlan regressziós együtthatók, szignifikancia szintek)

\begin{tabular}{|c|c|c|c|c|c|}
\hline & (2.a.) & (2.b.) & (3.a.) & (3.b.) & (3.c.) \\
\hline & \multicolumn{2}{|c|}{ társadalmi integráció } & \multicolumn{3}{|c|}{ szubjektív indikátorok } \\
\hline 2.a. Házas/ Élettárssal él & $\begin{array}{l}1,020 * * \\
(0,402)\end{array}$ & & & & \\
\hline 2.b. Dolgozik & & $\begin{array}{l}-0,163 \\
(0,432)\end{array}$ & & & \\
\hline 3.a. Kijövünk & & & $\begin{array}{c}4,196 * * * \\
(0,378)\end{array}$ & & \\
\hline $\begin{array}{l}\text { 3.b. Jó szubjektív } \\
\text { egészség }\end{array}$ & & & & $\begin{array}{c}4,701 * * * \\
(0,503)\end{array}$ & \\
\hline 3.c. Van biztonságérzete & & & & & $\begin{array}{c}2,733 * * * \\
(0,448)\end{array}$ \\
\hline Év: 2012 & $\begin{array}{l}-0,225 \\
(0,409)\end{array}$ & $\begin{array}{l}-0,371 \\
(0,368)\end{array}$ & $\begin{array}{c}0,116 \\
(0,357)\end{array}$ & $\begin{array}{l}-0,812 \\
(0,633)\end{array}$ & $\begin{array}{l}0,983 * \\
(0,527)\end{array}$ \\
\hline Interakciós tag & $\begin{array}{l}1,033 * * \\
(0,527) \\
\end{array}$ & $\begin{array}{l}1,332 * * \\
(0,514) \\
\end{array}$ & $\begin{array}{c}0,074 \\
(0,490) \\
\end{array}$ & $\begin{array}{c}0,925 \\
(0,684) \\
\end{array}$ & $\begin{array}{l}-0,883 \\
(0,583)\end{array}$ \\
\hline \multicolumn{6}{|l|}{ Kontrollváltozók } \\
\hline Férfi & $\begin{array}{l}-0,239 \\
(0,261)\end{array}$ & $\begin{array}{l}-0,183 \\
(0,262)\end{array}$ & $\begin{array}{l}-0,159 \\
(0,249)\end{array}$ & $\begin{array}{c}-, 268 \\
(0,252)\end{array}$ & $\begin{array}{l}-0,346 \\
(0,260)\end{array}$ \\
\hline 30-39 éves & $\begin{array}{c}-2,989 * * * \\
(0,439)\end{array}$ & $\begin{array}{c}-2,439 * * * \\
(0,436)\end{array}$ & $\begin{array}{c}-2,160 * * * \\
(0,405)\end{array}$ & $\begin{array}{c}-2,165^{* * * *} \\
(0,410)\end{array}$ & $\begin{array}{c}-2,308 * * * \\
(0,422)\end{array}$ \\
\hline 40-49 éves & $\begin{array}{c}-3,854 * * * \\
(0,427)\end{array}$ & $\begin{array}{c}-3,486 * * * \\
(0,419)\end{array}$ & $\begin{array}{c}-2,807 * * * \\
(0,394)\end{array}$ & $\begin{array}{c}-2,791 * * * \\
(0,399)\end{array}$ & $\begin{array}{c}-3,293 * * * \\
(0,408) \\
\end{array}$ \\
\hline $50-59$ éves & $\begin{array}{c}-3,964 * * * \\
(0,424)\end{array}$ & $\begin{array}{c}-3,579 * * * \\
(0,415)\end{array}$ & $\begin{array}{c}-3,115^{* * * *} \\
(0,394)\end{array}$ & $\begin{array}{c}-2,671 * * * \\
(0,401)\end{array}$ & $\begin{array}{c}-3,473 * * * \\
(0,409)\end{array}$ \\
\hline 60-69 éves & $\begin{array}{c}-3,587 * * * \\
(0,454)\end{array}$ & $\begin{array}{c}-2,883 * * * \\
(0,461)\end{array}$ & $\begin{array}{c}-3,015^{* * * *} \\
(0,423)\end{array}$ & $\begin{array}{c}-2,052 * * * \\
(0,433)\end{array}$ & $\begin{array}{c}-2,975^{* * * *} \\
(0,439)\end{array}$ \\
\hline 70 és idősebb & $\begin{array}{c}-3,783 * * * \\
(0,450)\end{array}$ & $\begin{array}{c}-3,400 * * * \\
(0,470)\end{array}$ & $\begin{array}{c}-3,716^{* * * *} \\
(0,429)\end{array}$ & $\begin{array}{c}-1,602 * * * \\
(0,455)\end{array}$ & $\begin{array}{c}-3,484 * * * \\
(0,449)\end{array}$ \\
\hline Nagyváros & $\begin{array}{l}-0,173 \\
(0,346)\end{array}$ & $\begin{array}{l}-0,425 \\
(0,345)\end{array}$ & $\begin{array}{c}-0,588^{*} \\
(0,328)\end{array}$ & $\begin{array}{c}-, 494 \\
(0,331)\end{array}$ & $\begin{array}{l}-0,112 \\
(0,343)\end{array}$ \\
\hline Város & $\begin{array}{c}-, 167 \\
(0,290)\end{array}$ & $\begin{array}{c}-0,220 \\
(0,291)\end{array}$ & $\begin{array}{c}-0,394 \\
(0,277)\end{array}$ & $\begin{array}{c}-, 288 \\
(0,280)\end{array}$ & $\begin{array}{l}-0,020 \\
(0,289)\end{array}$ \\
\hline Szakmunkás & $\begin{array}{c}0,257 \\
(0,336)\end{array}$ & $\begin{array}{c}0,307 \\
(0,340)\end{array}$ & $\begin{array}{c}-0,003 \\
(0,321)\end{array}$ & $\begin{array}{c}-, 041 \\
(0,325)\end{array}$ & $\begin{array}{c}0,286 \\
(0,333)\end{array}$ \\
\hline Érettségi & $\begin{array}{c}1,885 * * * \\
(0,352)\end{array}$ & $\begin{array}{c}1,993 * * * \\
(0,356)\end{array}$ & $\begin{array}{c}1,129 * * * \\
(0,340)\end{array}$ & $\begin{array}{c}1,435 * * * \\
(0,342)\end{array}$ & $\begin{array}{c}1,954 * * * \\
(0,349)\end{array}$ \\
\hline
\end{tabular}




\begin{tabular}{|c|c|c|c|c|c|}
\hline \multirow[b]{3}{*}{ Felsőfokú } & (2.a.) & (2.b.) & (3.a.) & (3.b.) & (3.c.) \\
\hline & \multicolumn{2}{|c|}{ társadalmi integráció } & \multicolumn{3}{|c|}{ szubjektív indikátorok } \\
\hline & $\begin{array}{c}3,995 * * * \\
(0,427)\end{array}$ & $\begin{array}{c}4,060 * * * \\
(0,438)\end{array}$ & $\begin{array}{c}2,849 * * * \\
(0,416)\end{array}$ & $\begin{array}{c}3,483 * * * \\
(0,415)\end{array}$ & $\begin{array}{c}3,830 * * * \\
(0,427)\end{array}$ \\
\hline $\begin{array}{l}\text { Egy före jutó havi nettó } \\
\text { háztartási jövedelem }\end{array}$ & $\begin{array}{c}1,640 \mathrm{E}-5^{* * *} \\
(0,000)\end{array}$ & $\begin{array}{l}1,534 \mathrm{E}-5 * * * \\
(0,000)\end{array}$ & $\begin{array}{c}6,489 \mathrm{E}- \\
6 * * * \\
(0,000)\end{array}$ & $\begin{array}{c}1,412 \mathrm{E}- \\
5 * * * \\
(0,000)\end{array}$ & $\begin{array}{c}1,483 \mathrm{E}- \\
5 * * * \\
(0,000)\end{array}$ \\
\hline Konstans & $\begin{array}{l}20,555 * * * \\
(0,504)\end{array}$ & $\begin{array}{l}21,040 * * * \\
(0,493)\end{array}$ & $\begin{array}{c}20,333 * * * \\
(0,476)\end{array}$ & $\begin{array}{c}16,906 * * * \\
(0,609)\end{array}$ & $\begin{array}{c}18,820 * * * \\
(0,583)\end{array}$ \\
\hline $\mathbf{N}$ & 2522 & 2503 & 2536 & 2536 & 2513 \\
\hline Korrigált $\mathbf{R}^{2}$ & 0,129 & 0,122 & 0,198 & 0,181 & $\mathbf{0 , 1 3 8}$ \\
\hline
\end{tabular}

Megjegyzés: a zárójelben lévö számok sztenderd hibák. Referencia kategóriák: (1.a.) egyedülálló, (1.b.) nem dolgozik, (2.a.) nem jönnek ki a havi bevételeikböl, (2.b.) rossz szubjektív egészség, (2.c.) nincs biztonságérzete, év: 2006. Kontrollváltozóknál: nö, 30 évtöl fiatalabb, falu+község+tanya, 8 általános vagy alacsonyabb. Hiányzó esetek: listwise. Szignifikancia szintek: $* p<0.10, * * p<0.05$, ***p $<0.01$ 


\section{F.14. Függelék: A hipotéziscsoportoknak a szubjektív életminőség mértékével kapcsolatos regressziós modelljei}

F.14. táblázat: A hipotéziscsoportoknak a szubjektív életminőség mértékével kapcsolatos regressziós modelljei, összevont keresztmetszeti adatok, OLS (sztenderdizálatlan regressziós együtthatók, szignifikancia szintek)

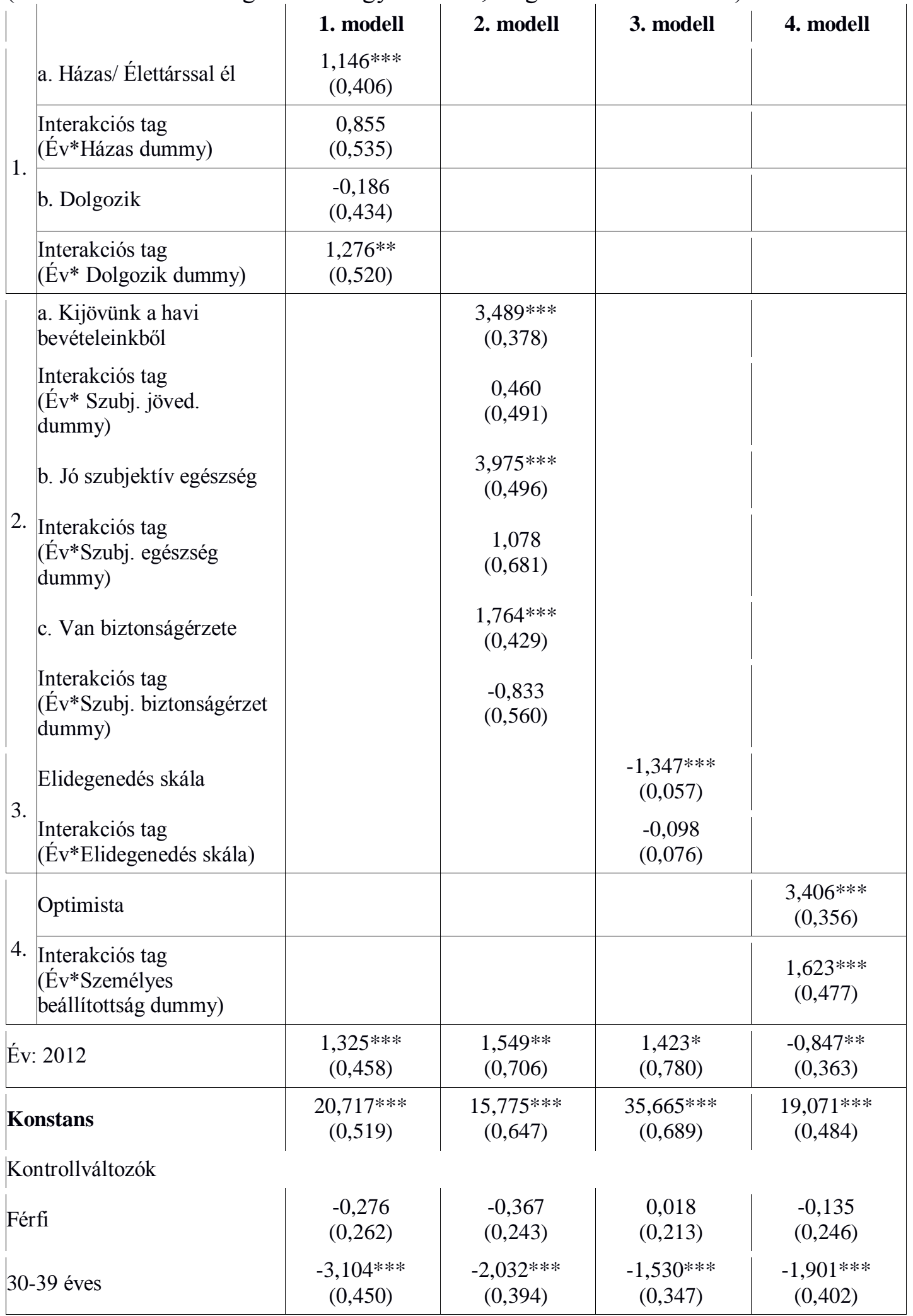




\begin{tabular}{|c|c|c|c|c|}
\hline & 1. modell & 2. modell & 3. modell & 4. modell \\
\hline 40-49 éves & $\begin{array}{c}-4,117 * * * \\
(0,436)\end{array}$ & $\begin{array}{c}-2,527 * * * \\
(0,383)\end{array}$ & $\begin{array}{c}-2,174 * * * \\
(0,337)\end{array}$ & $\begin{array}{c}-2,581^{* * * *} \\
(0,390)\end{array}$ \\
\hline 50-59 éves & $\begin{array}{c}-4,106^{* * * *} \\
(0,427)\end{array}$ & $\begin{array}{c}-2,496 * * * \\
(0,386)\end{array}$ & $\begin{array}{c}-2,577 * * * \\
(0,337)\end{array}$ & $\begin{array}{l}-2,587 * * * \\
(0,392)\end{array}$ \\
\hline 60-69 éves & $\begin{array}{c}-3,503 * * * \\
(0,471)\end{array}$ & $\begin{array}{c}-2,172 * * * \\
(0,415)\end{array}$ & $\begin{array}{c}-2,028 * * * \\
(0,364)\end{array}$ & $\begin{array}{c}-2,183 * * * \\
(0,421)\end{array}$ \\
\hline 70 éves és idősebb & $\begin{array}{c}-3,649 * * * \\
(0,471)\end{array}$ & $\begin{array}{c}-1,990 * * * \\
(0,441)\end{array}$ & $\begin{array}{c}-2,167 * * * \\
(0,371)\end{array}$ & $\begin{array}{c}-2,472 * * * \\
(0,428)\end{array}$ \\
\hline Nagyváros & $\begin{array}{l}-0,234 \\
(0,347)\end{array}$ & $\begin{array}{l}-0,534^{*} \\
(0,320)\end{array}$ & $\begin{array}{l}-0,092 \\
(0,238)\end{array}$ & $\begin{array}{l}-0,335 \\
(0,324)\end{array}$ \\
\hline Város & $\begin{array}{l}-0,173 \\
(0,291)\end{array}$ & $\begin{array}{l}-0,310 \\
(0,270)\end{array}$ & $\begin{array}{l}-0,092 \\
(0,238)\end{array}$ & $\begin{array}{l}-0,267 \\
(0,274)\end{array}$ \\
\hline Szakmunkás & $\begin{array}{c}0,250 \\
(0,340)\end{array}$ & $\begin{array}{l}-0,302 \\
(0,312)\end{array}$ & $\begin{array}{c}0,093 \\
(0,275)\end{array}$ & $\begin{array}{c}0,230 \\
(0,317)\end{array}$ \\
\hline Érettségi & $\begin{array}{c}1,870 * * * \\
(0,356)\end{array}$ & $\begin{array}{l}0,724 * * \\
(0,331)\end{array}$ & $\begin{array}{c}0,623 * * \\
(0,290)\end{array}$ & $\begin{array}{c}1,968 * * * \\
(0,331)\end{array}$ \\
\hline Felsőfokú & $\begin{array}{c}3,909 * * * \\
(0,437)\end{array}$ & $\begin{array}{c}2,202 * * * \\
(0,406)\end{array}$ & $\begin{array}{c}1,708 * * * \\
(0,355)\end{array}$ & $\begin{array}{c}3,743 * * * \\
(0,404)\end{array}$ \\
\hline $\begin{array}{l}\text { Egy fớre jutó havi nettó } \\
\text { háztartási jövedelem }\end{array}$ & $\begin{array}{l}1,603 \mathrm{E}-5^{* * *} \\
(0,000)\end{array}$ & $\begin{array}{l}6,241 \mathrm{E}-6^{* * * *} \\
(0,000)\end{array}$ & $\begin{array}{l}1,209 \mathrm{E}-5 * * * \\
(0,000)\end{array}$ & $\begin{array}{c}1,241 \mathrm{E}-5 * * * \\
(0,000)\end{array}$ \\
\hline $\mathbf{N}$ & 2488 & 2510 & 2481 & 2530 \\
\hline Korrigált $\mathbf{R}^{2}$ & 0,132 & 0,252 & 0,419 & 0,218 \\
\hline
\end{tabular}

Megjegyzés: a zárójelben lévő számok sztenderd hibák. Referencia kategóriák: (1.a.) egyedülálló, (1.b.) nem dolgozik, (2.a.) nem jönnek ki a havi bevételeikböl, (2.b.) rossz szubjektiv egészség, (2.c.) nincs biztonságérzete, (4) pesszimista, év: 2006. Kontrollváltozóknál: nö, 30 évtöl fiatalabb, falu+község+tanya, 8 általános vagy alacsonyabb. Hiányzó esetek: listwise. Szignifikancia szintek: $* p<0.10, * * p<0.05, * * * p<0.01$ 


\section{F.15. Függelék: A szubjektív életminőség integrált regressziós modellje (II.)}

F.15. táblázat: A szubjektív életminőség integrált regressziós modellje (II.), összevont keresztmetszeti adatok, OLS (sztenderdizálatlan regressziós együtthatók, szignifikancia szintek)

\begin{tabular}{|c|c|}
\hline & II. modell \\
\hline Év: 2012 & $0,615(1,173)$ \\
\hline Házas/Élettárssal él & $0,640 * *(0,314)$ \\
\hline Inter (Év*Házas dummy) & $0,007(0,412)$ \\
\hline Dolgozik & $-0,633 *(0,338)$ \\
\hline Inter (Év*Dolgozik dummy) & $0,711 *(0,414)$ \\
\hline Kijönnek a havi bevételeikből & $2,367 * * *(0,319)$ \\
\hline Inter (Év*Szubj. jöv. helyzet dummy) & $-0,080(0,420)$ \\
\hline Jó szubjektív egészség & $2,316 * * *(0,429)$ \\
\hline Inter (Év*Szubj. egészség dummy) & $-0,089(0,597)$ \\
\hline Van biztonságérzete & $1,045 * * *(0,360)$ \\
\hline Inter (Év*Biztonságérzet dummy) & $-0,646(0,469)$ \\
\hline Elidegenedés skála & $-1,109 * * *(0,058)$ \\
\hline Inter (Év*Elidegenedés skála) & $-0,057(0,079)$ \\
\hline Optimista & $1,625 * * *(0,301)$ \\
\hline Inter (Év*Személyes beállítottság dummy) & $0,977 * *(0,414)$ \\
\hline Konstans (B) & $27,541 * * *(0,920)$ \\
\hline \multicolumn{2}{|l|}{ Kontrollváltozók } \\
\hline Férfi & $-0,184(0,203)$ \\
\hline 30-39 éves & $-1,606 * * *(0,351)$ \\
\hline 40-49 éves & $-1,950 * * *(0,342)$ \\
\hline 50-59 éves & $-2,019 * * *(0,337)$ \\
\hline 60-69 éves & $-1,676 * * *(0,372)$ \\
\hline 70 éves és idősebb & $-1,379 * * *(0,388)$ \\
\hline Nagyváros & $0,028(0,271)$ \\
\hline Város & $-0,198(0,226)$ \\
\hline Szakmunkás & $-0,216(0,264)$ \\
\hline Érettségi & $0,136(0,280)$ \\
\hline Felsőfokú & $0,840 * *(0,346)$ \\
\hline Egy fớre jutó havi nettó háztartási jövedelem & $5,963 \mathrm{E}-6 * * *(0,000)$ \\
\hline $\mathbf{N}$ & 2404 \\
\hline Korrigált $\mathbf{R}^{2}$ & 0,496 \\
\hline
\end{tabular}

Megjegyzés: zárójelben a sztenderd hibák. Referencia kategóriák: év: 2006, (1.a.) egyedülálló, (1.b.) nem dolgozik, (2.a.) nem jönnek ki a havi bevételeikböl, (2.b.) rossz szubjektív egészség, (2.c.) nincs biztonságérzete, (4) pesszimista. Kontrollváltozóknál: nö, 30 évtöl fiatalabb, falu+község+tanya, 8 általános vagy alacsonyabb. Listwise. Szignifikancia szintek: $* p<0.10, * * p<0.05, * * * p<0.01$. 


\section{Irodalom}

Allardt, Erik (1973): About Dimensions of Welfare: An Exploratory Analysis of a Comparative Scandinavian Survey. Research Reports, Nr.1, Research Group for Comparative Sociology, Finland, Helsinki: University of Helsinki. Forrás: http://worlddatabaseofhappiness.eur.nl/hap bib/freetexts/allardt e 1973.pdf (letöltés: 2015. 12. 17.)

Allardt, Erik (1976): Dimensions of welfare in a Comparative Scandinavian Study, Acta Sociologica, 19. (3): 227-239.

Allardt, Erik (1993): Having, Loving, Being: An Alternative to the Swedish Model of Welfare Research. In: Martha Nussbaum - Amartya Sen (Eds.): The Quality of Life. Oxford, UK: Clarendon Press. 88-94.

Andorka Rudolf - Kulcsár Rózsa (1975a): Egy társadalmi jelzőszámrendszer körvonalai, Statisztikai Szemle, 53. (5): 459-478.

Andorka Rudolf - Kulcsár Rózsa (1975b): Egy társadalmi jelzőszámrendszer körvonalai, Statisztikai Szemle, 53. (6): 589-607.

Andorka Rudolf (1992): Társadalmi változások és társadalmi problémák, 19401990, Statisztikai Szemle, 70. (4-5): 301-324.

Andorka Rudolf (1996): Deviáns viselkedések Magyarországon. Általános értelmezési keret az elidegenedés és az anómia fogalmak segítségével. In: Uő: Merre tart a magyar társadalom, Lakitelek: Antológia, 127-146.

Andorka Rudolf - Spéder Zsolt (1996): A szegénység Magyarországon 1992-1995, Esély, 7. (4): 25-52.

Andrews, Frank M. - Withey, Stephen B. (1974): Developing Measures of Perceived Life Quality: Results from Several National Surveys, Social Indicators Research, 1. (1): 1-26.

Argyle, Michael (1996): Subjective Well-Being. In: Avner Offer (Ed.): In Pursuit of the Quality of Life, New York: Oxford University Press, 18-45.

Argyle, Michael - Martin, Maryanne (1991): The psychological causes of happiness. In: Fritz Strack - Michael Argyle - Norbert Schwarz (Eds.): Subjective Well-being: An Interdisciplinary Perspective, Oxford: Pergamon Press, 77-100.

Babbie, Earl (1996): A társadalomtudományi kutatás gyakorlata, Budapest: Balassi.

Babbie, Earl (2007): The practice of Social Research (Eleventh Edition), Wadsworth: Cengage Learning.

Beck, Ulrich ([1985] 2003): A kockázat-társadalom. Út egy másik modernitásba, Budapest: Andorka Rudolf Társadalomtudományi Társaság - Századvég Kiadó.

Berger-Schmitt, Regina - Noll, Heinz-Herbert (2000): Conceptual Framework and Structure of a European System of Social Indicators. EuReporting Working PaperNo. 9., Mannheim: Centre for Survey Research and Methodology, ZUMA 
Bjørnskov, Christian (2014): Do Economic Reforms Alleviate Subjective Wellbeing Losses of Economic Crisis?, In: Journal of Happiness Studies, 15. (1): 163-182. http://dx.doi.org/10.1007/s10902-013-9442-y.

Blanchflower, David G. - Oswald, Andrew J. (2011): International Happiness, NBR Working Paper Series. Forrás: http://www.nber.org./papers/w16668 (letöltés: 2015. 12.17.)

Blossfeld, Hans-Peter - Mills, Melinda (2005): Globalization, uncertainty and the early life course. A theoretical framework. In: Hans-Peter Blossfeld - Erik Klijzing - Melinda Mills - Karin Kurz (Eds.): Globalization, Uncertainty and Youth in Society, London - New York: Routledge, pp. 1-24.

Buckley, Jack - Shang, Yi (2003): Estimating Policy and Program Effects with Observational Data: The „Differences in Differences” Estimator, Practical Assessment, Research \& Evaluation, 8. (24): 1-8.

Forrás: http://PAREonline. net/ getvn.asp?v=8\&n=24

Bukodi, Erzsébet (2001): Társadalmi jelzőszámok - elméletek és megközelítések, Szociológiai Szemle, 11. (2): 35-57.

Campbell, Angus - Converse, Philip E. - Rodgers, Willard L. (1976): The Quality of American Life, New York: Russel Sage Foundation.

Clark, Andrew E. (2003): Unemployment as a Social Norm: Psychological Evidence from Panel Data, In: Journal of Labor Economics, 21. (2): 323-351.

Clark, Andrew - Oswald, Andrew J. (1994): Unhappiness and Unemployment, In: Economic Journal, 104. (5): 648-659. http://dx.doi.org/10.2307/2234639.

Clench-Aas, Jocelyne - Holte, Arne (2017): The financial crisis in Europe: Impact on satisfaction with life. In: Scandinavian Journal of Public Health, 45. (18): 30-40., http://dx.doi.org/10.1177/1403494817718692

Cummins, Robert A. - Wooden, Mark (2014): Personal Resilience in Times of Crisis: The Implications of SWB Homeostasis and Set-Points, Journal of Happiness Studies, 15. (1): 223-235. http://dx.doi.org/10.1007/s10902-0139481-4

Cummins, Robert A. - Li, Ning - Wooden, Mark - Stokes, Mark (2014): A Demonstration of Set-Points for Subjective Wellbeing, Journal of Happiness Studies, 15. (1): 183-206. http://dx.doi.org/10.1007/s10902-013-9444-9

Csath Magdolna (2010): Kit válasszunk?, Budapest: Kairosz.

Delhey, Jan - Böhnke, Petra - Habich, Roland - Zapf, Wolfgang (2002): Quality of Life in a European Perspective: The EUROMODUL as a New Istrument for Comparative Welfare Research, Social Indicators Research, 58. (1-3): 163-176.

Diener, Ed (1984): Subjective Well-Being, Psychological Bulletin, 95 (3): 542-575.

Diener, Ed (1994): Assessing Subjective Well-Being: Progress and Opportunities, Social Indicators Research, 31. (2): 103-157.

Forrás: https://internal.psychology.illinois.edu/reprints (letöltés: 2015.12.17.)

Diener, Ed - Biswas-Diener, Robert (2000): New Direction in Subjective WellBeing Research: The Cutting Edge, Indian Journal of Clinical Psychology, 27. (1): 21-33. 
Forrás: https://internal.psychology.illinois.edu/reprints (Letöltés: 2015. 12. 20.)

Diener, Ed - Eunkook M. Suh - Richard E. Lucas - Heidi L. Smith (1999): Subjective Well-Being: Three Decades of Progress, Psychological Bulletin, 125. (2): 276-302.

Forrás: https://internal.psychology.illinois.edu/reprints (letöltés: 2015.12.17.)

Diener, Ed - Fujita, Frank (1997): Social Comparisons and Subjective Well-Being. In: Bram P. Buunk - Frederick X. Gibbons (Eds.): Health, Coping and WellBeing: Perspectives from Social Comparison Theory. Mahwah, NJ: Erlbaum, 329-357.

Diener, Ed - Lucas, Richard E. (1999): Personality and subjective well-being. In: Daniel Kahneman - Ed Diener - Norbert Schwarz (Eds.): Well-being: The Foundations of Hedonic Psychology, New York: Russell-Sage Foundation, 213-229.

Diener, Ed - Oishi, Shigehiro - Lucas, Richard E. (2015): National Accounts of Subjective Well-Being, American Psychologist, $70 . \quad$ (3): 234-242. http://dx.doi.org/10.1037/a0038899

Diener, Ed - Suh, Eunkook (1999): National Differences in Subjective Well-Being. Forrás: http://www.psych.uiuc.edu/ ediener/hottopic/Diener-Suh.html (letöltés: 2004.11.24.)

Diener, Ed - Tov, William (2004): Culture and Subjective Well-Being. Forrás: http://psych.uiuc. edu/ ediener/hottopic/CultureSWB.html (letöltés: 2005. 02. 14.)

Diener, Ed - Wirtz, Derrick - Tov, William - Kim-Prieto, Chu - Choi, Dongwon - Oishi, Shigehiro - Biswas-Diener, Robert (2010): New Well-being Measures: Short Scales to Asses Flourishing and Positive and Negative Feelings, Social Indicators Research, $97 \quad$ (2): 143-156. http://dx.doi.org/10.1007/s11205-009-9493-y

Di Tella, Rafael - MacCulloch, Robert J. - Oswald, Andrew J. (2001): Preferences over inflation and unemployment: Evidence from surveys of happiness, American Economic Review, 91. (1): 335-341.

Dow, Greg K. - Juster, F. Thomas (1985): Goods, Time, and Well-Being: The Joint Dependence Problem. In: F. Thomas Juster - Frank P. Stafford (Eds.): Time, Goods, and Well-Being, Ann Arbor, USA: University of Michigan Press, 397-413.

Durkheim, Émile (1986): A társadalmi munkamegosztásról, Budapest: Osiris.

Durkheim, Émile (1982): Az öngyilkosság, Budapest: Közgazdasági és Jogi Könyvkiadó.

Easterlin, Richard A. (1974): Does Economic Growth Improve the Human Lot? Some Empirical Evidence. In: Paul A. David - Malvin W. Reder (Eds.): Nations, Households and Economic Growth: Essays in Honor of Mozes Abramowitz, New York: Academic Press, 89-125.

Easterlin, Richard A. (2001): Income and Happiness: Towards a Unified Theory, Economic Journal, 111. (July): 465-484. 
Easterlin, Richard A. (2009): Lost in transition: Life satisfaction on the road to capitalism, Journal of Economic Behavior \& Organization, 71. (2): 130-145. http://dx.doi.org/10.1016/j.jebo.2009.04.003

Easterlin, Richard A. (2013): Happiness, growth, and public policy, Economic Inquiry, 51. (1): 1-15. http://dx.doi.org/10.1111/j.1465-7295.2012.00505.x

Elekes Zsuzsanna - Paksi Borbála (2000): Anómia, lelki problémák, elégedettségaz ezredév végén. In: Spéder Zsolt (szerk.): A jólét, elégedettség és társadalmi kohézió Magyarországon, Budapest: BKÁE, 71-84.

European Commission (2014): Coping with the crisis. Aggregate Report. Eurobarometer Qualitative Study, EU: European Commission, DirectorateGeneral for Employment, Social Affairs and Inclusion.

Forrás:http://ec.europa.eu/public_opinion/archives/quali/ql_6342_crisis_en.pdf (letöltés: 2015. 12. 11.)

Frey, Bruno S. - Stutzer, Alois (1999): Happiness, Economy and Institutions. Institute for Empirical Research in Economics, University of Zurich, Working Paper No. 15. Forrás: http://www.iew.uzh.ch/wp/iewwp15.pdf (letöltés: 2005. 04. 16.)

Frey, Bruno S. - Stutzer, Alois (2001): What Can Economists Learn from Happiness Research?, Institute for Empirical Research in Economics, University of Zurich, Working Paper No. 80.

Forrás: http://www.iew.uzh.ch/wp/iewwp80.pdf (letöltés: 2015. 12. 08.)

Frey, Bruno S. - Stutzer, Alois (2003a): Does Marriage People Happy, Or Do Happy People Get Married. Institute for Empirical Research in Economics, University of Zurich, Working Paper No. 143.

Forrás: http://www.iew.uzh.ch/wp/iewwp143.pdf (letöltés: 2015. 12. 08.)

Frey, Bruno S. - Stutzer, Alois (2003b): Testing Theories of Happiness, Institute for Empirical Research in Economics, University of Zurich, Working Paper No. 147. Forrás: http://www.iew.uzh.ch/wp/iewwp147.pdf (letöltés: 2015. 12. 08.)

Frey, Bruno S. - Stutzer, Alois (2004): Happiness Research: State and Prospects, Institute for Empirical Research in Economics, University of Zurich, Working Paper No.190. Forrás: http://www.iew.uzh.ch/wp/iewwp190.pdf (letöltés: 2015. 12. 08.)

Füstös László (2010): Látens változós modellek. (A sokváltozós matematikaistatisztika módszerei), Európai Társadalomtudományi Elemzések-Módszertani Füzetek 2010/2, Társadalomtudományi Elemzések Akadémiai Mühelye, Budapest: MTA SZKI.

Füstös László (2011): Társadalmi indikátorok, társadalmi terek (Európai társadalmak a bizalomtérben, a politikai aktivitástérben, az igazságosságtoleranciatérben és az elégedettségtérben). In: Antalóczy Tímea - Füstös László (szerk.): Társadalmi Füzetek 2011/3, Budapest: MTA SZKI/MTA PTI.

Gardner, Jonathan - Oswald, Andrew (2001): Does Money Buy Happiness? A Longitudinal Study Using Data Windfalls, Forrás:http://www2.warwick.ac.uk/fac/soc/economics/staff/ajoswald/morepub 
(letöltés: 2015. 11.27.)

Garhammer, Manfred (2002): Pace of Life and Enjoyment of Life, Journal of Happiness Studies, 3. (3): 217-256.

Gábos András - Branyiczki Réka - Barbara Lange - Tóth István György (2014): Aktív korúak foglalkoztatottsága és szegénysége az Európai Unióban és Magyarországon: válság előtt, alatt és után. In: Kolosi Tamás - Tóth István György (szerk.): Társadalmi Riport 2014, Budapest: TÁRKI, 179-203.

Gábos András - Tátrai Annamária - B. Kis Anna - Szivós Péter (2016): Anyagi depriváció Magyarországon, 2009-2015. In: Kolosi Tamás - Tóth István György (szerk.): Társadalmi Riport 2016, Budapest: TÁRKI, 130-150.

Graham, Carol - Chattopadhyay, Soumya - Picon, Mario (2010): Adapting to Adversity: Happiness and the 2009 Economic Crisis in the United States. In: Social Research, An International Quarterly, 77. (2): 715-748. (no DOI nr)

Graham, Carol - Pettinato, Stefano (2002): Frustrated Achievers: Winners, Losers and Subjective Well-Being in New Market Economies, Journal of Development Studies, 38. (4): 100-140.

Graham, Liam - Oswald, Andrew J. (2010): Hedonic capital, adaptation and resilience, Journal of Economic Behavior \& Organization, 76. (2): 372-384. http://dx.doi.org/10.1016/j.jebo.2010.07.003

Greve, Bent (2012): The impact of the financial crisis on happiness in affluent European countries, Journal of Comparative Social Welfare, 28. (3): 183-193. http://dx.doi.org/10.1080/17486831.2012.736354

Gudmundsdottir, Dora G. - Ásgeirsdóttir, Bryndís B. - Huppert, Felicia A. Sigfúsdóttir, Inga D. - Valdimarsdóttir, Unnur A. - Hauksdóttir, Arna (2016): How Does the Economic Crisis Influence Adolescents' Happiness? Population-Based Surveys in Iceland in 2000-2010, Journal of Happiness Studies, 17. (3): 1219-1234. http://dx.doi.org/10.1007/s10902-015-9639-3.

Gudmundsdottir, Dora G. (2013): The Impact of Economic Crisis on Happiness, Social Indicators Research, $110 . \quad$ (1): $1083-1101$. http://dx.doi.org/10.1007/s11205 -011-9973-8.

Gylfason, Thorvaldur - Holmström, Bengt - Korkman, Sixten - Söderström, Hans T. - Vihriälä, Vesa (2010): From Boom to Bust: The Iceland Story, In: Thorvaldur Gylfason - Bengt Holmström - Sixten Korkman - Hans T. Söderström - Vesa Vihriälä: Nordics in Global Crisis. Voulnerability and Resilience, Helsinki: Taloustieto Oy, 137-166.

Hagenaars, J. - Halman, L. - Moors, G. (2003): Exploring Europe's Basic Values Map, In: Arts, W. - Hagenaars, J. - Halman, L. (Eds.): The Cultural Diversity of European Unity. Findings, Explanations and Reflections from the European Values Study. Leiden, Boston: Brill, 23-48.

Hajdú Gábor - Hajdú Tamás (2011): Elégedettség és relatív jövedelem: a referenciacsoport összetételének hatása az információs és státuszhatás erősségére, Szociológiai Szemle, 21. (3): 83-106.

Hank, Karsten - Wagner, Michael (2013): Parenthood, Marital Status, and Well- 
being in Later Life: Evidence from SHARE, Social Indicators Research, 114. (2): 639-653. http://dx.doi.org/10.1007/s11205-012-0166-x

Hankiss Elemér - Manchin Róbert (1976): Szempontok az élet "minőségének" szociológiai vizsgálatához, Valóság, 19. (1): 20-34.

Hankiss Elemér (1980): Structural variables in Cross-Cultural Research on the Quality of Life. In: Alexander Szalai - Frank M. Andrews (Eds.): The Quality of Life. Comparative Studies, SAGE Studies in International Sociology, 20., 41-56.

Harcsa, István - Spéder, Zsolt (1999): Social Reporting and Social Indicators Movemenet in Hungary before and after the Transformation, EuReporting Working Paper No. 4, Budapest: Central Statistical Office/Budapest University of Economic Sciences

Harrison, Eric - Quick, Annie - Abdallah, Saamah (eds.) (2016): Looking through the Wellbeing Kaleidoscope, London: New Economics Foundation

Headey, Bruce (2006): Subjective Well-Being: Revision to Dynamic Equilibrium Theory Using National Panel Data and Panel regression Methods, Social Indicators Research, 79. (3): 369-403. http://dx.doi.org/10.1007/s11205-0055381-2

Headey, Bruce (2008): The Set-Point Theory of Well-being: Negative Results and Consequent Revisions. In: Social Indicators Research, 85. (3): 389-403. http://dx.doi.org/10.1007/s11205-007-9134-2.

Headey, Bruce (2010): The Set-Point Theory of Well Being Has Serious Flaws: On the Eve of a Scientific Revolution?, Social Indicators Research, 97. (1): 7-21. http://dx.doi.org/10.1007/s11205-009-9559-x

Headey, Bruce - Kelley, Jonathan - Wearing, Alexander J. (1993): Dimensions of Mental Health: Life Satisfaction, Positive Affect, Anxiety and Depression, Social Indicators Research, 29. (1): 63-82.

Headey, Bruce - Muffels, Ruud - Wagner, Gert G. (2014): National Panel Studies Show Substantial Minorities Recording Long-Term Change in Life Satisfaction: Implications for Set-Point Theory, In: Kennon M. Sheldon Richard E. Lucas (Eds.): Stability of Happiness, Theories and Evidence on Whether Happiness Can Change, USA: Elsevier, 101-126.

Headey, Bruce - Wearing, Alexander (1989): Personality, Life Events, and Subjective Well-Being: Toward a Dynamic Equilibrium Model, Journal of Personality and Social Psychology, 57. (4): 731-739.

Headey, Bruce - Wearing, Alexander (1991): Subjective well-being: a stocks and flows framework. In: Fritz Strack - Michael Argyle - Norbert Schwarz (Eds.): Subjective Well-being: An Interdisciplinary Perspective. Oxford: Pergamon Press, 49-73.

Hegedüs Rita (2000): Normaszegések elfogadása és érzékelése a köztudatban. In: Spéder Zsolt (szerk.): A jólét, elégedettség és társadalmi kohézió Magyarországon, Budapest: BKÁE, 85-94.

Hegedús Rita (2001): Szubjektív társadalmi indikátorok - szelektív áttekintés a téma irodalmából, Szociológiai Szemle, 11. (2): 58-72. 
Helliwell, John F. - Huang, Haifang - Wang, Shun (2014): Social Capital and Well-Being in Times of Crisis, Journal of Happiness Studies, 15. (1): 145-162. http://dx.doi.org/10.1007/s10902-013-9441-z

Hirvilammi, Tuuli - Helne, Tuula (2014): Changing Paradigms: A Sketch for Sustainable Wellbeing and Ecosocial Policy, Sustainability, 6. (4): 2160-2175. http://dx.doi.org/10.3390/su6042160

Huppert, Felicia A. - So, Timothy T. C. (2013): Flourishing Across Europe: Application of a New Conceptual Framework for Defining Well-Being, Social Indicators Research, Vol. 110, No. 3, pp. 837-861. http://dx.doi.org/10.1007/s11205-011-9966-7

Husz Ildikó (2001): Az emberi fejlődés indexe, Szociológiai Szemle, 11. (2): 72-83.

Inglehart, Ronald - Basanez, Miguel - Moreno, Alejandro (1998): Human Values and Beliefs: A Cross-Cultural Sourcebook. Political, Religious, Sexual, and Economic Norms in 43 Societies: Findings from the 1990-1993 World Value Survey, Ann Arbor, USA: University of Michigan Press, Forrás: https://www.adturtle.biz/LP TA/index.cfm?T=436857 (letöltés: 2015 . 12. 18.)

Inman, Robert P. - Oberholzer-Gee, Felix (2003): Democratic Institutions and Subjective Well-being, USA: University of Pennsylvania.

Forrás: https://fnce.wharton.upenn.edu/profile/inman/\#research (Letöltés: 2005. 01. 22.)

Ivony Éva (2017): Szubjektív életminőség és érzelmi jóllét a gazdasági válság előtt és azt követően, európai kitekintéssel, Statisztikai Szemle, 95. (10): 997-1022. http://dx.doi.org/10.20311/stat2017.10.hu0997

Keller Tamás (2008): Trendek az életszínvonallal való elégedettséget magyarázó tényezők hatásának időbeli alakulásában 1992 és 1997 között. In: Kolosi Tamás - Tóth István György (szerk.): Társadalmi Riport 2008, Budapest: TÁRKI, 415-428.

Keller Tamás (2010): Magyarországi értéktérkép: normakövetés, egyéni teljesítmény, szolidaritás, és öngondoskodás elfogadottsága a magyar társadalomban, Szociológiai Szemle, 20. (2): 42-70.

Keyes, Corey Lee M. (2002): The mental health continuum: From languishing to flourishing in life, Journal of Health and Social Behavior, 43. (2): 207-222.

Keyes, Corey Lee M. (2007): Promoting and protecting mental health as flourishing, American Psychologist, 62. (2): 95-108. http://dx.doi.org/10.1037/0003066X.62.2.95

Kim-Prieto, Chu - Diener, Ed - Tamir, Maya - Scollon, Christie - Diener, Marissa (2005): Integrating the Diverse Definitions of Happiness: A TimeSequential Framework of Subjective Well-Being, Journal of Happiness Studies, 6. (3): 261-300. http://dx.doi.org/10.1007/s10902-005-7226-8

Kolosi Tamás - Rudas Tamás (1998): Empirikus problémamegoldás a szociológiában. Társadalomkutatási Módszertani Tanulmányok. I., Budapest: OMIKK-TÁRKI

Kopp Mária (szerk.) (2008): Magyar lelkiállapot 2008. Esélyerősítés és 
életminőség a mai magyar társadalomban, Budapest: Semmelweis Kiadó.

Kopp Mária - Skrabski Árpád (2000): A magyar lelkiállapot és a társadalmi tőke szerepe a népegészségügyi mutatók alakulásában, In: Elekes ZsuzsannaSpéder Zsolt (szerk.): Törések és kötések a magyar társadalomban, Budapest: Andorka Rudolf Társadalomtudományi Társaság - Századvég Kiadó, 254-264.

Kopp Mária - Skrabski Árpád (2009): Nők és férfiak egészségi állapota Magyarországon, In: Nagy Ildikó-Pongrácz Tiborné (szerk.): Szerepváltozások: Jelentés a nők és férfiak helyzetéröl 2009, Budapest: TÁRKI, 117-136.

Lane, Robert E. (1996): Quality of Life and Quality of Persons: A New Role for Government?, In: Avner Offer (Ed.): In Pursuit of the Quality of Life, New York: Oxford University Press, 256-293.

Lane, Robert E. (2000): Diminishing returns to income, companionship - and happiness, Journal of Happiness Studies, 1. (1): 103-119.

Layard, Richard (2007): Boldogság. Fejezetek egy új tudományból, Győr: Lexecon.

Lelkes Orsolya (2003): A pénz boldogít? A jövedelem és hasznosság kapcsolatának empirikus elemzése, Közgazdasági Szemle, 50. (5): 383-405.

Lengyel György (szerk.) (2002): Indikátorok és elemzések. Mühelytanulmányok a társadalmi jelzöszámok témaköréböl, Budapest: BKÁE.

Lengyel György - Hegedüs Rita (2004): A szubjektív jólét objektív tényezői nemzetközi összehasonlításban, In: Helmich Dezső - Szántó Zoltán (szerk.): Módszertan, gazdaság, társadalom. In memoriam Bertalan László, Budapest: Közgazdasági Szemle Alapítvány, 298-310.

Lengyel György - Janky Béla (2003): A szubjektív jólét társadalmi feltételei, Esély, 14. (1): 3-25.

Lengyel György - Szántó Zoltán (szerk.) (1998): Tőkefajták: A társadalmi és kulturális erőforrások szociológiája. Budapest: Aula.

Lengyel György - Tóth István János (1998): Osztályhelyzet, jövedelmi esélyek, elégedettség, Századvég, Új folyam, (Nyár) 9., 49-70.

Lim, Hock-Eam (2008): The Use of Different Happiness Rating Scale: Bias and Comparison Problem?, Social Indicators Research, 87. (2): 259-267. http://dx.doi.org/10.1007/s11205-007-9171-x

Lucas, Richard E. - Diener, Ed - Suh, Eunkook (1996): Discriminant Validity of Well-Being Measures, Journal of Personality and Social Psychology, 71. (3): 616-628.

Lucas, Richard E. - Clark, Andrew E. - Georgellis, Yannis - Diener, Ed (2003): Reexamining adaptation and the set point model of happiness: Reactions to changes in marital status, Journal of Personality and Social Psychology, 84. (3): 527-539.

Lucas, Richard E. - Clark, Andrew E. - Georgellis, Yannis - Diener, Ed (2004), Unemployment alters the set point for life satisfaction, Pschological Science, 15. (1): 8-13.

Luhmann, Maike - Hofmann, Wilhelm - Eid, Michael - Lucas, Richard. E. (2012): Subjective Well-Being and Adaptation to Life Events: A Meta- 
Analysis on Differences Between Cognitive and Affective Well-Being, Journal of Personality and Social Psychology, 102. (3): 592-615. http://dx.doi.org/10.1037/a0025948

Madden, David (2011): The impact of an Economic Boom on the Level and Distribution of Subjective Well-Being: Ireland, 1994-2001, Journal of Happiness Studies, 12. (4): 667-679. http://dx.doi.org/10.1007/s10902-0109222-X

Maslow, Abraham (1943): A theory of human motivation, Psychological Review, 50., 370-396. http://dx.doi.org/10.1037/h0054346

Medgyesi Márton (2016): A háztartások megtakarításai és eladósodottsága Magyarországon, 2008-2015, In: Kolosi Tamás - Tóth István György (szerk.): Társadalmi Riport 2016, Budapest: TÁRKI, 173-192.

Medgyesi Márton - Nagy Ildikó (2014): Fiatalok életkörülményei Magyarországon és az EU országaiban 2007 és 2012 között, In: Kolosi Tamás - Tóth István György (szerk.): Társadalmi Riport 2014, Budapest: TÁRKI, 303-323.

Merton, Robert K. (2002): Társadalomelmélet és társadalmi struktúra, Budapest: Osiris.

Michalos, Alex C. - Zumbo, Bruno D. (2000): Criminal victimization and the quality of life, Social Indicators Research, 50. (3): 245-295.

Michalos, Alex C. - Zumbo, Bruno D. (2002): Healthy days, Health satisfaction and satisfaction with the overall quality of life, Social Indicators Research, 59. (3): 321-338.

Moksony, Ferenc (2006): Gondolatok és adatok. Társadalomtudományi elméletek empirikus ellenőrzése (2. bővített kiadás), Budapest: Aula.

National Bureau of Economic Research (2007): What's New in Econometrics? Difference-in-Differences Estimation, Massachusetts, Cambridge, NBER, Source: http://www.nber.org/WNE/lect_10_diffindiffs.pdf

Noll, Heinz-Herbert (2002): Social Indicators and Quality of Life Research: Background, Achievements and Current Trends. Forrás: http://www.gesis.org/fileadmin/upload/institut/wiss_arbeitsbereiche/soz_indika toren/Publikationen/isscnoll.pdf (letöltés: 2015.12.11.)

Noll, Heinz-Herbert (2011): The Stiglitz-Sen-Fitoussi-report: old wine in new skins? Views from a social indicators perspective, In: Social Indicators Research, 102. (1): 111-116., http://dx.doi.org/10.1007/s11205-010-9738-9

Oswald, Andrew J. (1997): Happiness and Economic Performance, Economic Journal, 107, 1815-1831.

Oswald, Andrew J. (2003): How Much Do External Factors Affect Wellbeing? A Way to Use 'Happiness Economics' to Decide, Psychologist, 16. (3): 140-141.

Oswald, Andrew J. - Wu, Stephen (2009): Well-being across America, IZA Discussion Paper, No. 4600, Forrás: http://ftp.iza.org/dp4600.pdf

Patrick, Donald (2006): Short History of Health-Related Quality of Life Research, In: Sirgy et al. (2006): The Quality-of-Life (QOL) Research Movement: Past, 
Present, and Future, Social Indicators Research, 76. (3): 343-466. http://dx.doi.org/10.1007/ s11205-005-2877-8., pp. 399-408.

Raibley, Jason R. (2012): Happiness is not Well-being, Journal of Happiness Studies, 13. (6): 1105-1129. http://dx.doi.org/10.1007/s10902-011-9309-z

Rossouw, Stephanié - Pacheco, Gail (2012): Measuring Non-Economic Quality of Life on a Sub-National Level: A Case Study of New Zealand, Journal of Happiness Studies, 13. (3): 439-454. http://dx.doi.org/10.1007/s10902-0119272-8

Ryan, Richard M. - Chirkov, Valery I. - Little, Todd D. - Sheldon, Kennon M. - Timoshina, Elena - Deci, Edward L. (1999): The American Dream in Russia: Extrinsic Aspirations and Well-Being in Two Cultures, Personality and Social Psychology Bulletin, 25. (12): 1509-1524.

Ryff, Carol D. (1989): Happiness Is Everything, or Is It? Explorations on the Meaning of Psychological Well-Being, Journal of Personality and Social Psychology, 57. (6): 1069-1081.

Ryff, Carol D. - Keyes, Corey Lee M. (1995): The Structure of Psychological Well-Being Revisited, Journal of Personality and Social Psychology, 69. (4): 719-727.

Sajtos László - Mitev Ariel (2007): SPSS Kutatási és Adatelemzési Kézikönyv, Budapest: Alinea.

Sági Matild (2000): Az anyagi helyzettel való elégedetlenség és a vonatkoztatási csoportok, In: Kolosi Tamás - Tóth István György - Vukovich György (szerk.): Társadalmi Riport 2000, Budapest: TÁRKI, 260-297.

Sági Matild (2002): Elégedettség, jövedelmi feszültség, In: Kolosi Tamás - Tóth István György - Vukovich György (szerk.): Társadalmi Riport 2002, Budapest: TÁRKI, 75-94.

Schimmack, U. - Radhakrishnan, P. - Oishi, S. - Dzokoto, V. - Ahadi, S. (2001): Culture, Personality and Subjective Well-being: Integrating Process Models of Life-Satisfaction, Journal of Personality and Social Psychology, 82 (4): 582593. http://dx.doi.org/10.1037//0022-3514.82.4.582

Schulz, Wolfgang (1995): Multiple-discrepancies theory versus resource theory, Social Indicators Research, 34. (1): 153-169.

Schwarz, Norbert - Strack, Fritz (1991): Evaluating one's life: a judgment model of subjective well-being, In: Fritz Strack - Michael Argyle - Norbert Schwarz (Eds.): Subjective Well-being: An Interdisciplinary Perspective, Oxford: Pergamon Press, 27-47.

Seeman, Melvin (1959): On the meaning of alienation, American Sociological Review, 24. (6): 783-791.

Sen, Amartya (1993): Capability and Well-Being. In: Martha Nussbaum - Amartya Sen (Eds.): The Quality of Life, Oxford: Oxford University Press,

Siposne Nandori, Eszter (2016): How Did Subjective-Well-Being Change in Hungary Due to the Economic Crisis, Social Indicators Research, 126. (1): 241-256. http://dx.doi.org/10.1007/s11205-015-0878-9 
Sirgy, M. Joseph - Michalos, Alex C. - Ferriss, Abbott L. - Easterlin, Richard A. - Patrick, Donald - Pavot, William (2006): The Quality-of-Life (QOL) Research Movement: Past, Present, and Future, Social Indicators Research, 76. (3): 343-466. http://dx.doi.org/10.1007/ s11205-005-2877-8.

Spéder Zsolt (szerk.) (2000): A jólét, elégedettség és társadalmi kohézió Magyarországon, Budapest: BKÁE

Spéder Zsolt - Paksi Borbála - Elekes Zsuzsanna (1998): Anómia és elégedettség a 90-es évek elején, In: Kolosi Tamás - Tóth István György - Vukovich György (szerk.): Társadalmi Riport 1998, Budapest: TÁRKI, 490-513.

Spéder Zsolt - Kapitány Balázs (2002): A magyar lakosság elégedettségének meghatározó tényezői nemzetközi összehasonlításban, In: Kolosi Tamás Tóth István György - Vukovich György (szerk.): Társadalmi Riport 2002, Budapest: TÁRKI, 162-172.

Stewart, Frances (1996): Basic Needs, Capabilities and Human Development, In: Awner Offer (Ed.): In Pursuit of the Quality of Life, Oxford, NY: Oxford University Press, 46-65.

Szabó Laura (2003): A boldogság relatív - Fogyatékosság és szubjektív életminőség, Szociológiai Szemle, 13. (3): 86-105.

Szivós Péter - Tóth István György (szerk.) (2013): Egyenlötlenség és polarizálódás a magyar társadalomban, TÁRKI Monitor Jelentések 2012, Budapest: TÁRKI.

Szivós Péter - Tóth István György (2015): Jól nézünk ki (...?!) Háztartások helyzete a válság után, TÁRKI Monitor Jelentések 2014, Budapest: TÁRKI

Tóth István György (2016): Középosztályok Magyarországon és Európában, In: Kolosi Tamás - Tóth István György (szerk.): Társadalmi Riport 2016, Budapest: TÁRKI, 75-97.

Utasi Ágnes (2000): A társadalmi integráció: a részvétel és a kapcsolatok néhány aspektusa, In: Spéder Zsolt (szerk.): A jólét, elégedettség és társadalmi kohézió Magyarországon, Budapest: BKÁE, 95-110.

Utasi Ágnes (2002): A bizalom hálója. Mikrotársadalmi kapcsolatok, szolidaritás, Budapest: Új Mandátum.

Utasi Ágnes (2006): A minőségi élet és forrásai, In: Utasi Ágnes (szerk.): A szubjektív életminőség forrásai, Budapest: MTA PTI, 14-15.

Utasi Ágnes (2008): Éltető kapcsolatok, A kapcsolatok hatása a szubjektív életminőségre, Budapest: Új Mandátum Könyvkiadó.

Utasi Ágnes (2011): Szubjektív feszültség és munkastressz a házasok életében. Összehasonlítás Európa 24 országában, In: Nagy Ildikó - Pongrácz Tiborné (szerk.): Szerepváltozások: Jelentés a nők és férfiak helyzetéröl 2011, Budapest: TÁRKI, 243-264.

Van Praag, Bernard M.S. - Frijters, Paul - Ferrer-i Carbonell, Ada (2001): The Anatomy of Subjective Well-Being, Timbergen Institute Discussion Papers, Nr.02-022/3., Forrás: https://ideas.repec.org/s/tin/wpaper10.html

Varga Károly (2002): Az életminőség értékrendszeri tényezői, Társadalomkutatás, 
20. (3-4): 217-245.

Veenhoven, Ruut (1993): Happiness in Nations: Subjective Appreciation of Life in 56 Nations 1946-1992, Rotterdam, Erasmus University: RISBO Press.

Veenhoven, Ruut (2000): The Four Qualities of Life. Ordering Concepts and Measures of the Good Life, Journal of Happiness Studies, 1. (1): 1-39.

Veenhoven, Ruut (2014): Long-term Change of Happiness in Nations: Two Times More Rise than Decline Since the 1970s, In: Kennon M. Sheldon - Richard E. Lucas (Eds.): Stability of Happiness, Theories and Evidence on Whether Happiness Can Change, USA: Elsevier, 167-200.

Veenhoven, Ruut (2016): Happiness in Hungary (HU), World Database of Happiness, Erasmus University Rotterdam, The Netherlands, Viewed on 201612-17 at http://worlddatabaseofhappiness.eur.nl

Veenhoven, Ruut - Hagerty, Michael (2006): Rising Happiness in Nations 19462004: A Reply to Easterlin, Social Indicators Research, 79. (3): 421-436. http://dx.doi.org/10.1007/s11205-005-5074-x

Vogel, Joachim (1997): The future direction of social indictor research, Social Indicators Research, 42. (2): 103-116.

Wrosch, Carsten - Scheier, Michael F. (2003): Personality and quality of life: The importance of optimism and goal adjustment, Quality of Life Research, 12. (1): 59-72.

Zapf, Wolfgang (1980): The SPES Social Indicators System in Comparative Perspective. In: Alexander Szalai - Frank M. Andrews (Eds.): The Quality of Life. Comparative Studies, SAGE Studies in International Sociology 20, 249269.

Zapf, Wolfgang (2000): Social reporting in the 1970s and in the 1990s, Social Indicators Research, 51. (1): 1-15.

Zapf, Wolfgang (2002): Jólét és társadalom. In: Wolfgang Zapf: Modernizáció, jólét, átmenet. Budapest: Andorka Rudolf Társadalomtudományi Társaság Századvég Kiadó, 219-295. 


\section{Publikációs jegyzék}

\section{A szerzőnek a témában megjelent publikációi:}

\section{Folyóiratcikkek}

Ivony Éva (2017): Szubjektív életminőség és érzelmi jóllét Magyarországon a gazdasági válság előtt és azt követően, európai kitekintéssel. In: Statisztikai Szemle 95. (10): 997-1022. http://dx.doi.org/10.20311/stat2017.10.hu0997

Ivony, Eva (2018): Changes of the subjective quality of life after the economic crisis in Hungary, Forthcoming in: Corvinus Journal of Sociology and Social Policy (attached document)

\section{Egyéb}

Elöadások

Ivony Éva: Az érzelmi jóllét változása Európában az ezredfordulót követően Társadalmi helyzetkép európai összehasonlitásban, A 'European Social Survey' legfrissebb kutatási eredményei, Mühelykonferencia, MTA TK SZI, Budapest, 2016. június 14. 